UNIVERSIDADE DE SÃO PAULO

FACULDADE DE FILOSOFIA, LETRAS E CIÊNCIAS SOCIAIS

PROGRAMA DE PÓS-GRADUAÇÂO EM SOCIOLOGIA

\title{
O REVISIONISMO DE EDUARD BERNSTEIN E A NEGAÇÃO DA DIALÉTICA
}

JOANA EL-JAICK ANDRADE 
JOANA EL-JAICK ANDRADE

\section{O REVISIONISMO DE EDUARD BERNSTEIN E A NEGAÇÃO DA DIALÉTICA}

Dissertação de Mestrado apresentada ao Programa de Pós-Graduação em Sociologia da Faculdade de Filosofia, Letras e Ciências Humanas da Universidade de São Paulo, com vistas à obtenção do título de Mestre em Sociologia.

Orientador: Prof. Dr. Ricardo Musse 


\section{O revisionismo de Eduard Bernstein e a negação da dialética}

Dissertação submetida à banca de Mestrado como requisito necessário à obtenção do título de Mestre em Sociologia pelo Programa de Pós-Graduação em Sociologia da Universidade de São Paulo. Orientador: Prof. Dr. Ricardo Musse

São Paulo, 19 de outubro de 2006.

Banca examinadora:

Prof. Dr. Ricardo Musse - Universidade de São Paulo/FFLCH

Prof. Dr. Sedi Hirano - Universidade de São Paulo/FFLCH

Prof.Dr. Charles Pessanha - Universidade Federal do Rio de Janeiro/ IFCS 


\section{AGRADECIMENTOS}

Expresso minha dívida e profunda gratidão para com meu orientador, professor Ricardo Musse, por seu encorajamento, zelo e valiosas contribuições, o professor Sedi Irano e os colegas da disciplina "Seminário de Projeto", pelas inúmeras sugestões ao projeto inicial desta dissertação, os professores Ruy Braga e Celso Frederico, pelas pertinentes e enriquecedoras observações críticas, os professores da Universidade Federal do Rio de Janeiro Charles Pessanha e Franklin Trëin, por seu incentivo e amizade, os funcionários da Secretaria de Pós-Graduação em Sociologia e da Biblioteca Central da Faculdade de Filosofia, Letras e Ciências Humanas da Universidade de São Paulo, por sua gentileza e atenção. 
Para João, Ceres, Débora, Inês e Alexandre. 
Em sua forma mistificada, a dialética foi moda alemã porque ela parecia tornar sublime o existente. Em sua configuração racional, é um incômodo e um horror para a burguesia e para os seus porta-vozes doutrinários, porque no entendimento positivo do existente ela inclui ao mesmo tempo o entendimento da sua negação, da sua desaparição inevitável; porque apreende cada forma existente no fluxo do movimento, portanto também com seu lado transitório; porque não se deixa impressionar por nada e é, em sua essência, crítica e revolucionária.

Karl Marx, 1873 


\section{Sumário}

Introdução.

\section{1 - A Social-Democracia Alemã}

1.1- Origens da social-democracia e sua unificação em torno do Programa de Gotha.............

1.2- A repressão e a reestruturação do movimento.

\section{2 - Do Revisionismo Prático ao Revisionismo Teórico}

2.1- A década de 1890 e o surto industrial.

2.2- Os novos desafios decorrentes da legalização do partido.

2.3- O caráter conciliatório do Programa de Erfurt

2.4- Cisão interna e fortalecimento do reformismo.

\section{3- Eduard Bernstein e a Social-Democracia}

3.1- A trajetória política de Bernstein.

3.2- A revisão do marxismo

3.2.1- Bernstein e o desenvolvimento do capitalismo moderno.

3.2.2- A evolução social em direção ao socialismo.

3.2.3- Entre o materialismo e o idealismo.

3.2.4- A perspectiva anti-revolucionária e a rejeição da dialética.

\section{4 - O Bernstein-Debatte e sua Repercussão}

4.1- A indefinição da "ortodoxia". 
5 - Considerações finais sobre a suposta "crise do marxismo"

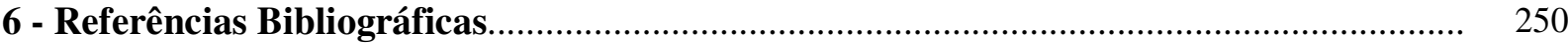

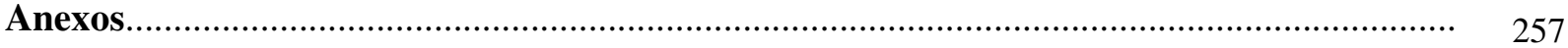




\section{RESUMO}

Nos fins do século XIX, Eduard Bernstein causou grande espanto e turbulência no interior da social-democracia alemã ao refutar publicamente as teses oficiais propugnadas pelos líderes do partido e, ao mesmo tempo, propor a revisão crítica do pensamento de Marx, desferindo sérios ataques ao que considerava seu elemento "nefasto": a dialética hegeliana. Ao defender a rejeição da filosofia da história marxiana - considerada obstáculo ao conhecimento científico da realidade social - Bernstein rompe com a perspectiva revolucionária, aderindo a um reformismo evolucionista. Acreditando no potencial emancipador da democracia burguesa, que tornaria possível a tomada do poder por meios legais e pacíficos, Bernstein passa a sustentar a adoção de uma postura política conciliatória e a mitigação da luta de classes. O surgimento desta corrente revisionista deu início a um grande cisma no interior da social-democracia que veio a ser considerado como "a primeira crise do marxismo", introduzindo uma nova tendência de rechaço à concepção dialética da história e de abdicação de quaisquer pretensões revolucionárias. Estas idéias viriam a tornarse hegemônicas no final do século XX, quando as teses que apregoam o "fim da história" são amplamente difundidas e festejadas. Diante deste novo refluxo das teorias e práticas revolucionárias, torna-se fundamental a análise minuciosa do fenômeno revisionista - o contexto em que surge, as razões de seu sucesso no âmbito da esquerda e as críticas que podem lhe ser opostas.

Palavras-chave: marxismo; partidos políticos; social-democracia; socialismo; revisionismo. 


\begin{abstract}
In the end of the nineteenth century, Eduard Bernstein caused great turbulence in the German social democracy when he publicly opposed to the official theses of the leaders of the Social Democratic Party and, at the same time, recommended a critical revision of Marx's thought, making serious attacks on what he considered its most hideous element: the Hegelian dialectics. While supporting the total rejection of the Marxian philosophy of history regarded as an obstacle to the scientific knowledge of the social reality - Bernstein breaks up with the revolutionary perspective, joining an evolutionary reformism. Relying in the emancipatory potential of the bourgeois democracy, that would make possible the achievement of power through legal and pacific means, Bernstein sustained a conciliatory political posture and the softening of the class struggle. The appearance of such revisionist tendency gave birth to a schism inside social democracy that was further known as "the first crisis of Marxism", as it excluded the dialectical conception of history and the revolutionary aim. These ideas became hegemonic at the end of the twentieth century, when theses proclaiming "the end of history" were widely spread. In face of the new reflux of the revolutionary praxis, the analysis of the revisionist phenomenon - the context in which it appears, the reason for its success and the critics opposed to it - becomes crucial.
\end{abstract}

Key-words: Marxism; political parties; revisionism; social democracy; socialism. 


\section{Introducão}

"Eduard Bernstein (1850-1932): social-democrata alemão, oportunista furioso; apelou, depois da morte de Engels, para a revisão do marxismo"”.

Nos fins do século XIX, Eduard Bernstein causou grande espanto e turbulência no interior do movimento operário europeu ao refutar publicamente as teses oficiais propugnadas pelos líderes do Partido Social-Democrata Alemão (SPD) e propor a revisão crítica do pensamento de Marx. Bernstein, um dos principais expoentes da social-democracia alemã, passou a desferir sérios ataques ao que considerava o elemento "nefasto" da teoria marxista: a dialética hegeliana. Assim, a partir da rejeição da filosofia da história marxiana - considerada obstáculo ao conhecimento científico da realidade social - o autor empreendeu uma ruptura definitiva com a perspectiva revolucionária, aderindo a um reformismo evolucionista.

Acreditando no potencial emancipatório da democracia burguesa, que a seu ver tornaria possível a tomada do poder por meios legais e pacíficos, Bernstein passou, então, a sustentar a adoção de uma postura política conciliatória e a mitigação da luta de classes. Neste sentido, a luta por reformas não mais seria vista como um meio para o preparo da luta pelo socialismo, mas o lento e gradual processo de aperfeiçoamento da sociedade existente.

A difusão das idéias bernsteinianas deu impulso ao surgimento de uma nova corrente política dentro da Segunda Internacional, sob a alcunha de "revisionismo". A ampla adesão a esta vertente ocasionou inúmeras disputas internas no âmbito dos partidos de massa e sindicatos que culminaram no processo de fragmentação da social-democracia, cujo auge pôde ser constatado com o advento da Primeira Guerra Mundial.

Ao longo do século XX, o persistente e infatigável trabalho de combate a esta nova tendência de rechaço à concepção dialética da história e de abdicação de quaisquer pretensões revolucionárias, em suas múltiplas variações, deu ensejo a importantes análises acerca do desenvolvimento do fenômeno revisionista e a numerosas tentativas de compreensão de seu alcance e significado. Contudo, nem sempre tal exame foi realizado com a profundidade e seriedade requeridas, sendo freqüentemente prejudicado por favoritismos ou interesses políticos. A epígrafe acima, extraída do índice onomástico das "Obras Escolhidas de Marx e Engels", publicadas em 1953 pelo Instituto de Marxismo-leninismo de Moscou, anexo ao Comitê Central do PCUS, oferece um bom exemplo desta tendência, evidenciando o juízo de

\footnotetext{
${ }^{1}$ MARX, Karl \& ENGELS, F. Obras escolhidas. v. 3, São Paulo: Alfa-Omega, 1980.
} 
valor a que foi submetida a imagem de Eduard Bernstein pelas gerações de marxistas que o sucederam.

A reiterada condenação das idéias bernsteinianas por inúmeros intelectuais de renome e ilustres membros da esquerda contemporânea pode nos conduzir a uma série de questionamentos acerca da penetração das teses revisionistas no âmbito do movimento operário e suas possíveis repercussões.

Ademais, é pertinente apurar como Bernstein, um dos principais teóricos da socialdemocracia durante o final do século XIX e início do século XX, amigo e herdeiro testamentário de Engels, visto por seus companheiros como dotado de uma honestidade intelectual ímpar, temperamento dócil e sincera humildade, tornou-se uma das figuras mais repudiadas da tradição marxista, ora taxado como oportunista, ora removido do âmbito de suas fileiras ${ }^{2}$ ? Por qual razão sua trajetória política, marcada pela indiscutível dedicação ao partido, à defesa das liberdades públicas e $\operatorname{privadas}^{3}$ e à construção de um regime "socialmente justo e democrático", acabou identificada com a aberta e hostil rejeição ao socialismo? Ou, ainda, seria adequado responsabilizá-lo pelo refluxo da teoria e prática revolucionárias e pela perda de radicalidade que abrange contemporaneamente a esquerda mundial, evidenciados na adesão explícita ou velada dos partidos à "terceira via", implicando no descarte do socialismo, na aceitação dos estreitos limites do mercado e na subordinação da política social a critérios de "governabilidade" e "eficiência", típicos do neoliberalismo?

A fim de responder a estas e outras indagações torna-se necessário recorrermos à análise do revisionismo bernsteiniano como fenômeno histórico, à procura das influências e implicações recíprocas que concorreram para seu aparecimento e para sua progressiva hegemonia dentro do Partido Social-Democrata Alemão - considerado modelo de organização partidária socialista nos séculos XIX e XX.

Assim, este trabalho tem por escopo analisar o surgimento e o desenvolvimento do revisionismo no interior da social-democracia alemã, considerando as críticas que lhe foram endereçadas pelas demais correntes do partido. Buscamos aferir as razões e conseqüências de sua influência sobre grande parte do movimento operário, no intuito de oferecer subsídios para a compreensão do triunfo das facções reformistas em 1914 - representado pela adesão do

\footnotetext{
${ }^{2}$ Ver ANDERSON, Perry. Considerações sobre o marxismo ocidental. $2^{\text {a }}$ ed. São Paulo: Brasiliense, 1989.

${ }^{3}$ Bernstein foi uma das poucas vozes dentro do movimento socialista alemão a partir em defesa da liberdade sexual, na ocasião do julgamento de Oscar Wilde tendo dedicado dois artigos na Die Neue Zeit à questão (BERNSTEIN. "On the occasion of a sensational trial" - 1895, In: www.marxists.org; BERNSTEIN. "The judgement of abnormal sexual intercourse" - 6/5/1895, In: www.marxists.org).
} 
partido à política imperialista do Reich - bem como de sua hegemonia no âmbito da esquerda no final do século XX, quando as teses que apregoam o "fim da história" são amplamente difundidas e festejadas.

Neste sentido, o primeiro capítulo desta dissertação procura analisar as inúmeras tendências e frações políticas que deram origem à social-democracia alemã, inserindo-as no contexto histórico político, econômico e social da Alemanha Guilhermina. O segundo capítulo pretende abordar o desenvolvimento do Partido Social-Democrata Alemão e o surgimento de grupos reformistas e anti-revolucionários em seu interior, sobretudo após a legalização do partido e a institucionalização de suas atividades. O terceiro capítulo tem como eixo principal o exame das teses revisionistas de Eduard Bernstein e a análise de sua trajetória, de forma a identificar as diversas influências que atuaram sobre sua teoria e prática política. O quarto capítulo procura apresentar os principais protagonistas do Bernstein-Debatte, no intuito de pontuar e delinear os principais argumentos e críticas oriundos tanto da "ortodoxia" como da ala revolucionária do SPD. Por fim, o último capítulo busca tecer algumas considerações finais sobre o fenômeno revisionista e a suposta "crise do marxismo", bem como contribuir para o resgate da discussão acerca dos limites do reformismo e da necessária revitalização da radicalidade no seio da esquerda.

Este trabalho, portanto, é norteado pela idéia fundamental de que a polêmica consubstanciada nos termos "reforma ou revolução" não deve ser vislumbrada como uma "peça de museu"4, mas, ao contrário, como uma questão a ser constantemente repensada e sopesada, tendo em vista a conjuntura histórica e a forma revestida pela luta de classes em determinada fase do capitalismo, objetivando, precisamente, à sua superação. Sob este prisma, toda a experiência acumulada pela ação conjunta das forças socialistas, seus avanços e retrocessos, potencialidades e contradições, contribui para a construção de novas alternativas de luta e para a reavaliação crítica do próprio movimento.

\footnotetext{
${ }^{4}$ De acordo com Marco Aurélio Garcia, "A polêmica reforma X revolução é hoje peça de museu, o que não significa que seja irrelevante. Ao contrário a reconstrução historiográfica de sua emergência e de seu curso ulterior e a compreensão teórica dos problemas que recobre apresentam uma atualidade muito grande" (GARCIA, Marco Aurélio. "Reforma e revolução / reforma ou revolução". In: Revista Brasileira de História. São Paulo: ANPUH/Marco Zero, vol.10, n.20 - março/agosto de 1990, p. 38.)
} 


\section{1 - A Social-Democracia Alemã}

\section{1- Origens da social-democracia e sua unificação em torno do Programa de Gotha}

Em meados do século XIX, a Europa havia sido varrida por uma onda de revoltas populares. A crise econômica que assolou grande parte dos países nos anos de 1846 e 1847 provocou um alto índice de desemprego, a falta de alimento nas cidades, o aumento dos preços e a disseminação de inúmeras doenças entre a população, gerando um clima de intensa agitação e efervescência revolucionária entre as camadas médias e baixas da sociedade, influenciadas por uma vasta gama de ideais vinculados ao liberalismo, nacionalismo, humanismo, materialismo, racionalismo e socialismo ${ }^{5}$.

As idéias socialistas e comunistas, no entanto, possuíam ainda uma tímida penetração nos círculos proletários, imbuídos fortemente de uma visão de mundo tradicional. O avanço das novas relações capitalistas, sobretudo nas cidades, e a tendência à dissolução dos códigos morais e princípios de classificação social baseados no nascimento e posição - também fundados em valores que prezavam o mérito, a realização e a honra pessoal - suscitaram uma crescente insatisfação popular vinculada a um apego e valorização do passado.

Deste modo, como nos apresenta Barrington Moore Jr. ${ }^{6}$, as mudanças introduzidas pelo capitalismo industrial, consubstanciadas no processo de "modernização conservadora", produziram profundas transformações nas vidas e nos sentimentos dos trabalhadores comuns. A ruptura dos modos e estilos de vida tradicionais, centrados particularmente em um ethos corporativo que prescrevia regras e proibições éticas aos trabalhadores, conduziu à instabilidade econômica e à falta de perspectivas profissionais. Em decorrência, acirrava-se o conflito entre o modo de pensar e agir pré-capitalistas e capitalistas.

As novas relações de produção reduziam a oportunidade dos jornaleiros e aprendizes tornarem-se mestres de ofício nos grandes centros industriais e promoviam a concorrência e a competição entre trabalhadores no âmbito de um mercado caracterizado pela impessoalidade e pelo livre ingresso profissional. Além de não disporem de um lugar seguro na estrutura ocupacional, diante das inconstâncias e irregularidades dos ciclos econômicos, os

\footnotetext{
${ }^{5}$ Cf. HOBSBAWM, E. A era dos impérios. São Paulo: Paz e Terra, 2005.

${ }^{6}$ MOORE Jr. Barrington. As origens da ditadura e da democracia. São Paulo: Martins Fontes, 1983.
} 
trabalhadores careciam de qualquer situação reconhecida, ou pelo menos plenamente reconhecida, no sistema de status predominante, sendo excluídos da ordem social tradicional.

Mesmo entre os trabalhadores que ainda possuíam prestígio e status reconhecidos, exercendo funções ou usufruindo as prerrogativas econômicas das corporações de ofício, vigorava o receio de serem forçados a perder sua posição, e assim "descerem ao proletariado". Este novo estrato social era composto por uma pluralidade de grupos laborais, em sua maioria compostos por trabalhadores não-qualificados. Apesar de fragmentados, possuíam em comum as precárias condições de vida, baixos salários e a ausência de consideração pública, que contribuíam para forjar um senso de injustiça, descontentamento e potencial de revolta.

As inúmeras diferenciações no seio das classes trabalhadoras urbanas obstaculizavam a formação de uma percepção unitária e coerente de sua condição, bem como a articulação espontânea entre os seus variados setores. Por conseqüência,

os que mais sofriam eram aqueles que menos tinham a dizer sobre e contra os seus sofrimentos. Dizer que eram desarticulados não significa que nada faziam. De tempos em tempos, eles devem ter guarnecido algumas das barricadas (raras, na variante alemã do vendaval de 1848). Mas eles pouco criaram, se é que alguma coisa fizeram, no sentido de um diagnóstico independente de sua própria situação. Tampouco conseguiram, nesta altura, desenvolver quaisquer organizações permanentes, com fôlego próprio para combater ou transformar a situação ${ }^{7}$.

Neste sentido, a participação de uma pequena minoria dos artesãos e trabalhadores nas insurreições de 1848 e 1849 na Alemanha refletia menos a existência de pretensões políticas efetivamente revolucionárias do que a sua tentativa de integração à ordem social emergente e a reivindicação por salários mais "justos", proteção contra a autoridade arbitrária do empregador e respeito social. Ademais, muitos insurretos da Saxônia, de Hannover, de Württemberg e de outros Estados clamavam pela criação de um Estado pangermânico, constituído nos moldes de uma confederação monárquica.

Do mesmo modo, as reivindicações oriundas da burguesia e da pequena-burguesia concentravam-se, em reformas liberais moderadas, como a promulgação de uma constituição, a instalação de um Parlamento organizado acima das Dietas particularistas e a nomeação de

\footnotetext{
${ }^{7}$ MOORE Jr. Barrington. As origens da ditadura e da democracia. São Paulo: Martins Fontes, 1983, p.205.
} 
um imperador que representasse a unidade nacional, colocando-se acima dos príncipessoberanos ${ }^{8}$.

Contudo, o projeto de formação de uma "Alemanha livre e unificada", bem como a campanha pela institucionalização de uma ordem constitucional nos diversos Estados, sofreram reveses. A decretação do estado de sítio - com o acirramento da repressão policial e da censura - e a capitulação da burguesia aos apelos da aristocracia conduziram ao enfraquecimento do movimento e à dissolução da Assembléia Nacional Constituinte de Frankfurt - de cunho pseudo-liberal ${ }^{9}$ - em junho de 1849, após um ano em funcionamento.

Desta maneira, a adesão da burguesia à contra-revolução levou ao fracasso do movimento liberal-democrático na Alemanha e à outorga de uma constituição reacionária pelo rei da Prússia ${ }^{10}$. Como Marx apontou, temendo o radicalismo do povo, a burguesia alemã sufocou suas próprias aspirações revolucionárias no intuito de preservar seus interesses particularistas. Neste sentido, as revoluções alemãs de 1848 e 1849 configurariam um fenômeno secundário, diante das demais revoluções da Europa:

Longe de ser uma revolução européia, não passou de abafada ressonância da revolução européia num país atrasado. Em lugar de adiantar-se à sua época, atrasou-se em relação a ela em mais de cinqüienta anos. (...) A burguesia alemã desenvolvera-se com tanta languidez, tão covardemente e com tal lentidão, que, no momento em que se opôs, ameaçadora, ao feudalismo e ao absolutismo, foi de encontro à ameaçadora oposição do proletariado e de todas as camadas da população urbana, cujos interesses e idéias eram afins aos do proletariado ${ }^{11}$.

Depois de frustrada a experiência revolucionária pela fragmentação da frente popular - composta pela associação de forças entre democratas radicais, republicanos e socialistas - o

\footnotetext{
${ }^{8}$ Como Bakunin posteriormente observara em relação à burguesia alemã da época: "O que os afligia não era a falta de liberdade, com a qual não teriam sabido o que fazer, mas o fato de faltar-lhes força nacional, unitária, indivisível, somando-se à existência real de um grande número de pequenas tiranias. Sua paixão secreta, seu único objetivo era a formação de um grande Estado pangermânico, capaz de tudo tragar pela violência e diante do qual todas as outras nações tremeriam" (BAKUNIN, Mikhail. Estatismo e anarquia. São Paulo: Editora Imaginário, 2003, p.153).

${ }^{9}$ Esta Assembléia, instaurada em 22/5/1848 reunia membros da nobreza, da burguesia e da pequena-burguesia, com vistas à institucionalização de uma monarquia parlamentar. Segundo Bakunin, "toda a incapacidade revolucionária, para não dizer a insondável asneira dos democratas e dos revolucionários alemães, apareceu às claras. Os radicais prussianos jogaram-se a fundo no jogo parlamentar e desinteressaram-se por todo o resto. Acreditavam com seriedade na virtude das decisões parlamentares e os mais inteligentes dentre eles pensavam que as vitórias que conquistavam no parlamento decidiam a sorte da Prússia e da Alemanha. Eles haviam fixado uma tarefa impossível: conciliar o governo democrático e a igualdade" (Bakunin, 2003, p.188).

${ }^{10}$ A Constituição Prussiana outorgada pelo rei Frederico Guilherme IV instituía o sistema de três classes para as eleições do Landtag, além de restringir severamente o direito de expressão e associação.

${ }^{11}$ MARX; ENGELS. "A burguesia e a contra-revolução". Obras escolhidas. São Paulo: Alfa-Omega, v. 1, 1980, p.50. Escrito por Marx em 11/12/1848.
} 
incipiente movimento operário alemão seguiu rumos próprios, em direção à constituição de uma organização autônoma e independente. Se até 1847 os socialistas ainda tinham em mente que a conquista do poder somente poderia ser efetivada pela burguesia, cabendo-lhes tomar parte na revolução como meros auxiliares ${ }^{12}$, após 1849 passaram a sublinhar as suas divergências em relação aos democratas burgueses e pequeno-burgueses, a manifestar sua desconfiança em relação aos "aliados" do proletariado e a ressaltar a importância de uma "revolução permanente", ou seja, de uma crescente radicalização da revolução:

Enquanto os pequenos burgueses democratas querem concluir a revolução o mais rapidamente possível, depois de terem obtido, no máximo, os reclamos supramencionados, os nossos interesses e as nossas tarefas consistem em tornar a revolução permanente até que seja eliminada a dominação das classes mais ou menos possuidoras, até que o proletariado conquiste o poder do Estado, até que a associação dos proletários se desenvolva, não num só país, mas em todos os países predominantes do mundo, em proporções tais que cesse a competição entre os proletários desses países, e até que pelo menos as forças produtivas decisivas estejam concentradas nas mãos do proletariado. Para nós, não se trata de reformar a propriedade privada, mas aboli-la; não se trata de atenuar os antagonismos de classe, mas de abolir as classes; não se trata de melhorar a sociedade existente, mas de estabelecer uma nova ${ }^{13}$.

Cabe lembrar que nesta época o movimento operário ainda encontrava-se em seus primórdios. As associações de artesãos e os grupos e círculos democráticos freqüentados pela burguesia progressista - tais como os "comitês constitucionais" - predominavam no cenário político como representantes das camadas populares.

Assim, as primeiras organizações operárias assumiram a forma de sociedades de assistência mútua, geralmente integradas por trabalhadores pertencentes a um mesmo ramo produtivo ou profissão. Tais associações, desprovidas de um caráter de classe, eram toleradas e até estimuladas pelo governo ${ }^{14}$. Além destas, existiam ainda associações formadas por

\footnotetext{
${ }^{12}$ No projeto de programa para a Liga dos Comunistas, Engels dispunha: "Na Alemanha (...) ainda não se travou a batalha decisiva entre a burguesia e a monarquia absoluta. Mas, como os comunistas não podem acabar com a burguesia antes que ela chegue ao poder, convém-lhes ajudá-la a conquistá-lo o quanto antes, para que, o quanto antes, possam eliminá-la. Os comunistas, portanto, devem sempre tomar o partido da burguesia liberal contra os governos, recusando-se, contudo, a compartilhar das ilusões burguesas ou a dar ouvidos às promessas sedutoras acerca das mágicas vantagens que acarretará ao proletariado o triunfo da burguesia" (ENGELS. "Princípios do comunismo”. In: Friedrich Engels: Política - Coleção Grandes Cientistas Sociais, n.17. José Paulo Netto [org]. São Paulo: Ática, 1981, p.99).

${ }^{13}$ MARX; ENGELS. "Mensagem do Comitê Central à Liga dos Comunistas”. In: Obras escolhidas. São Paulo: Alfa-Omega, v. 1, 1980, p. 86-87. Escrito em março de 1850.

${ }^{14}$ GARCIA, J. Abellan. "Prefácio". In: LASSALLE, Ferdinand. Manifesto operário e outros textos. Brasília: Instituto Teotônio Vilela, 1999, p.13.
} 
intelectuais, operários e trabalhadores exilados em países como França, Inglaterra, Suíça e Bélgica - como o alfaiate Christian Wilhelm Weitling. Estes grupos, por sua vez, possuíam uma orientação variada, sofrendo influência de inúmeras correntes ideológicas, como do socialismo utópico, do comunismo, do liberalismo-democrático e do hegelianismo de esquerda.

Somente em 1846 os comunistas criaram na Alemanha organizações próprias, clandestinas, associadas às "sociedades de correspondência" de Londres, Paris e Bruxelas das quais participavam Marx e Engels. A "Federação dos Justos", criada por Schapper, Bauer e Moll deu origem, em 1847, à "Liga dos Comunistas", organizada com base nos princípios do centralismo democrático, possuindo comitês regionais vinculados a um comitê central, além de um órgão de imprensa. Em seu estatuto, constava expressamente: "A Liga persegue a derrocada da burguesia e o domínio do proletariado, a supressão da velha sociedade burguesa baseada no antagonismo de classes e a instauração de uma nova sociedade sem classes nem propriedade privada" 15 .

Não obstante haver inaugurado um novo modelo de associação internacional com um projeto revolucionário que incluía um programa e plano de ação proletários, a Liga não conseguiu expandir o número de seus filiados e difundir amplamente seus princípios, devido à encarniçada perseguição política exercida pelos governos. Como conseqüência, em 1852, a Liga dos Comunistas foi extinta ${ }^{16}$.

Após 1848, organizações criadas pela burguesia e pela pequena-burguesia, destinadas a artesãos e operários também começaram a surgir, como a "Fraternidade Operária Universal Alemã" (Allgemeine Deutsche Arbeiterverbrüderung) ${ }^{17}$, dirigida por Stephan Born, ou ainda os "Círculos Operários de Estudos" (Arbeiterbildungsverein), federação de pequenas associações operárias sob a direção de Schulze-Delitzch, deputado do Partido Progressista (Deutsche Fortschrittspartei). Tais organizações funcionavam como sociedades de socorro mútuo (Selbsthülfe) e cooperativas de consumo, de matérias-primas, de crédito ou de seguro contra doenças, tendo por objetivo "corrigir" as falhas do sistema capitalista, sem recorrer à

\footnotetext{
${ }^{15}$ RIAZANOV, David. Marx - Engels e a história do movimento operário. São Paulo: global, 1984, p.66.

${ }^{16}$ Cf. MARX, ENGELS, HESS. De la "liga de los justos” al partido comunista. México: Roca, 1973.

17 Em 1849 a Fraternidade contava com 170 unidades locais e quase 15.000 membros, sendo considerada o primeiro movimento de massas da Alemanha. Esta organização atuava em cooperação com sindicatos, conferindo apoio a greves, associações de assistência mútua, cooperativas e a defesa de uma constituição liberal (GARCIA, 1999, p.15).
} 
ajuda do Estado ou de organizações sindicais ${ }^{18}$. Desta maneira, pregavam o manchesterismo, alegando que a intervenção ativa do Estado sob a organização dos trabalhadores levaria à sua bancarrota e à diminuição do rendimento dos operários.

Em oposição a este tipo de organização, foi fundada em 1863 a Associação Geral dos Trabalhadores Alemães (Allegemeiner Deutscher Arbeiterverein - ADAV), sob o comando do advogado Ferdinand Lassalle (1825-1864). Seu programa procurava conjugar a crítica ao liberalismo progressista burguês com as reivindicações de democratas radicais. Deste modo, anunciava que o movimento operário deveria se organizar como um partido independente visando à realização de um trabalho de propaganda e mobilização "pacífica e legal" pela reforma do Estado monárquico:

Sob o nome de Associação Geral dos Operários Alemães, os abaixo assinados fundam, nos Estados confederados alemães, uma associação que, partindo da convicção de que só o sufrágio universal igual e direto pode assegurar uma representação conveniente dos interesses sociais da classe trabalhadora alemã, bem como a eliminação dos antagonismos de classe, prossegue o objetivo de agir, pela via pacífica e legal e, particularmente, conquistando a opinião pública, para o estabelecimento do sufrágio universal igual e direto. ${ }^{19}$

Assim, a meta principal da organização lassalleana resumir-se-ia à instituição de uma "monarquia social", mediante a conquista do sufrágio universal igual e direto. Neste sentido, somente através do exercício pleno das liberdades políticas o trabalhador poderia satisfazer seus interesses legítimos ${ }^{20}$, pois, segundo Lassalle, por meio do sufrágio direto e universal os órgãos legislativos ${ }^{21}$ poderiam obrigar o Estado a cumprir a sua "verdadeira função", isto é, "proporcionar e facilitar os grandes progressos da civilização". ${ }^{22}$

\footnotetext{
${ }^{18}$ Segundo Garcia, "com o seu cooperativismo, Schulze procurava manter a atividade dos artesãos, ao lado da indústria que se desenvolvia, e integrar os operários no Mittelstand. O Mittelstand "burguês" devia acolher também operários assalariados, que se integrariam por meio de cooperativas de produção ou dos efeitos do crescente bem-estar social (participação nos lucros" (Garcia, 1999, p.28).

${ }^{19}$ Programa da ADAV (MARX, Karl; ENGELS, F; LENIN, V. I. Critica do Programa de Gotha, Critica do Programa de Erfurt e Marxismo e Revisionismo. Porto: Portucalense, 1971, p.89).

${ }^{20}$ Em sua carta aberta (Offenes Antwortschreiben) ao Comitê Geral encarregado do Congresso Geral Operário Alemão em Leipzig, de 1/3/1863, posteriormente conhecida como "Manifesto Operário" (Arbeitermanifest), Lassalle declara: "A classe operária precisa integrar-se em um partido político independente e fazer do sufrágio universal, igual e direto, bandeira e lema desse partido. Só a representação das classes trabalhadoras nas câmaras legislativas alemãs pode satisfazer seus interesses legítimos em matéria política. Na dimensão política, o programa do Partido Operário é, e tem que ser, o início de uma mobilização pacífica e ordenada rumo a esse objetivo, com todos os meios legais ao seu alcance" (LASSALLE, Ferdinand. Manifesto operário e outros textos. Brasília: Instituto Teotônio Vilela, 1999, p. 52).

${ }^{21}$ "Quando se tiver elevado essa exigência nos órgãos legislativos, será possível discutir racional e cientificamente os limites, as formas e os meios de tal intervenção. Estejam seguros então de que os homens que
} 
Lassalle considerava, portanto, que seria a "vocação" e o "destino" do Estado intervir no sentido de proporcionar meios e condições para que os operários se organizassem e se associassem livremente ${ }^{23}$, especialmente através do fornecimento de capital ou empréstimos para financiar cooperativas de produção. De acordo com Lassalle, as cooperativas de produção, geridas de forma autônoma pelos trabalhadores, eliminariam a alienação e afastariam a ação da "lei de ferro" dos salários que tornaria toda atividade sindical ineficaz ${ }^{24}$ :

Converter a classe operária em seu próprio patrão: essa é a forma única com que se poderia superar essa cruel e férrea lei que determina o valor dos salários. (...) Se a classe operária for seu próprio patrão, desaparecerá a distinção entre salário e lucro, e com ela desaparece o salário propriamente, surgindo em seu lugar o rendimento do trabalho. A supressão do lucro empresarial da forma mais simples, pacífica e legal, ao reorganizar-se a classe operária como seu próprio empresário, mediante associações voluntárias, é o único meio de superar essa lei que, no sistema produtivo atual, distribui o rendimento da produção entre salário (apenas necessário para sustentar a vida do trabalhador) e todo o resto, que cabe ao empresário ${ }^{25}$.

Por conseguinte, a associação cooperativa autônoma e voluntária dos operários, viabilizada com o auxílio do Estado, seria o único caminho para que se saia do "deserto em que foi colocada a classe operária”. Para Lassalle, através das cooperativas de produção o estrato inferior da sociedade, representado pelos assalariados, elevar-se-ia ao Mittelstand, formando uma "nova classe média universal". Em contraste, o cooperativismo de SchulzeDelitzch seria incapaz de oferecer melhores condições de vida para as massas trabalhadoras, pois as cooperativas de crédito, de consumo e de matérias-primas beneficiariam um número cada vez mais reduzido de pessoas, isto é, o "universo coletivo" dos artesãos ${ }^{26}$.

Destarte, em sua concepção, seria não somente tarefa do Estado, mas "sua mais nobre obrigação", fomentar e desenvolver as associações operárias ${ }^{27}$. Sob a perspectiva de Lassalle, o Estado nada mais seria do que a "grande organização", ou "a grande cooperativa" das classes trabalhadoras, uma vez que a sociedade seria composta predominantemente por

compreenderem a situação de vocês e estiverem dedicados a esses assuntos, estarão de seu lado, armados com a espada da ciência, e saberão defender seus interesses" (Ibid, p.77).

${ }^{22}$ Para Lassalle, "esta é a vocação do Estado. Para isso ele existe, para isso sempre serviu e terá de servir" (Ibid, p.67).

${ }^{23}$ Ibid, p.66.

${ }^{24}$ Segundo a "lei férrea do salário", inspirada na teoria malthusiana, o salário é determinado pelo nível mínimo de subsistência aceito em cada época.

${ }^{25}$ Ibid, p. 66.

${ }^{26}$ Ibid, p.57.

${ }^{27}$ Ibid, p. 72. 
trabalhadores. Logo, as cooperativas de produção seriam "esquemas de assistência mútua totalmente legítimos, naturais e justos, que as classes trabalhadoras criariam para si mesmas, na qualidade de grande cooperativa, e concretamente para seus membros, como indivíduos"28.

A seu ver, portanto, a missão histórica da classe operária consistiria justamente na eliminação de todos os privilégios e na realização do "Estado moral", através da utilização do sufrágio universal e igualitário. Ao conceber o Estado como uma "unidade dos indivíduos reunidos em um todo moral", que tem por finalidade "educar o gênero humano para a liberdade” e, assim, “dar existência à humanidade”, Lassalle recaíra em um culto ao Estado, que deitava raízes em sua forte admiração pela filosofia hegeliana ${ }^{29}$.

Sua defesa de um Estado nacional forte e centralizado levou-o a apoiar a unificação da Alemanha sob o controle e a preponderância da monarquia prussiana e a aproximar-se de Bismarck. Na correspondência que manteve com o Primeiro Ministro ${ }^{30}$, Lassalle solicitavalhe, em segredo, patrocínio político e favores financeiros em troca do suporte ao governo conferido pelas massas trabalhadoras. $\mathrm{O}$ autor chega a lhe assegurar que a classe operária viria a aceitar um governo ditatorial, desde que este implementasse uma política paternalista:

[Os estatutos] o convencerão claramente do quanto é verdade que a classe trabalhadora sente uma inclinação instintiva para a ditadura, caso ela possa ser, de início, corretamente convencida de que esta será exercida em seu interesse; e o quanto, apesar de todas as opiniões republicanas - ou, antes, precisamente por causa delas -, estaria, portanto, inclinada, como eu lhe disse recentemente, a considerar a Coroa, em oposição ao egoísmo da sociedade burguesa, como a representante natural da ditadura social, se a Coroa, por seu lado, puder se decidir a dar o passo certamente muito improvável - de tomar uma linha revolucionária e transformar-se da monarquia das ordens privilegiadas em uma monarquia do povo, social e revolucionária ${ }^{31}$.

Em carta a Kugelmann, de 23 de fevereiro de 1865, Marx exprimira seu profundo desprezo pela tática política assumida por Lassalle e pelo absurdo fato de acreditar que o Estado prussiano poderia exercer uma ação socialista direta. Marx denunciara, então, que Lassalle havia feito um acordo com Bismarck, prometendo-lhe apoio à campanha militarista

\footnotetext{
${ }^{28}$ Ibid, p.77.

${ }^{29}$ Ibid, p.29-33.

${ }^{30}$ Publicada pela primeira vez em 1928, por Gustav Mayer (Mézáros, 2004, p.371).

${ }^{31}$ Carta de Lassalle a Bismarck de 8/6/1863 (Mézáros, 2004, p.370-371).
} 
pela anexação de Schleswig-Holstein - então território da Dinamarca - à Prússia, em troca do sufrágio universal ${ }^{32}$.

A ligação de Lassalle com o governo prussiano foi confirmada, após a sua morte, por declarações do próprio Bismarck:

Lassalle nada tinha que pudesse dar-me como ministro. O que me atraía nele era a figura humana: um dos homens mais engenhosos e amáveis com quem já tratei, muito ambicioso, absolutamente não-republicano; tinha convicção nacionalista e monárquica. Sua idéia, sua aspiração, era a de um império alemão, e tínhamos aí um ponto de contato. Lassalle era muito ambicioso e tinha dúvidas sobre se o império alemão devia adotar a dinastia Hohenzollern ou a dinastia Lassalle, mas não há dúvida de que era integralmente monarquista. Lamento que a sua posição política e a minha não me permitissem tratar muito com ele, mas me agradaria ter como vizinho um homem com uma capacidade e uma natureza espiritualmente tão rica quanto a sua ${ }^{33}$.

Apesar de sua defesa do sufrágio universal, Lassalle demonstrava compartilhar da profunda antipatia pelo liberalismo das classes médias, expressa por Bismarck. A própria organização do partido manifestava a inclinação de Lassalle ao autoritarismo. Como observou Robert Michels, a "estrutura da associação correspondia não só às qualidades pessoais de Lassalle, à indomável ambição de poder e ao caráter egocêntrico que faziam dele, homem de gênio, tão mau conhecedor de homens, mas também à sua concepção teórica da tarefa que incumbe a toda organização partidária"34.

A organização do partido seguia o modelo da "Nationalverein" (Liga Nacional Alemã), isto é, uma sociedade unitária constituída por uma Assembléia Geral (reunida anualmente) formada por delegados eleitos segundo o número de membros das associações locais; uma Diretoria Executiva composta por vinte e quatro membros eleitos pela Assembléia; e um Presidente do partido, com um mandato inicial de cinco anos. O Presidente possuía poderes quase totais: nomeava seus substitutos, seus plenipotenciários e até seu sucessor, decidia a ordem do dia, podia demitir os comissários (Bevollmächtige) que o representavam nos agrupamentos do partido, além de estar investido de poderes que lhe permitiam tomar decisões urgentes - posteriormente submetidas à Diretoria ou à Assembléia. A centralização do poder nas mãos do Presidente do partido era ainda acentuada pelo fato de

\footnotetext{
${ }^{32}$ MARX, ENGELS. Obras escolhidas. São Paulo: Alfa-Omega, v.3, 1980, p. 256-260.

${ }^{33}$ Lassalle, 1999, p.34-35.

${ }^{34}$ MICHELS, Robert. Os partidos políticos. São Paulo: Senzala, [196-], p.107.
} 
os membros da Diretoria encontrarem-se dispersos por toda a Alemanha, dificilmente podendo ser reunidos em uma assembléia ${ }^{35}$.

Segundo Lassalle, a concentração do poder dentro do partido seria sinal de sua força e coesão internas:

Essa grande associação, que se estende por quase todos os Estados alemães, funciona e se move com a coesão compacta de um só indivíduo. Muitos poucos grupos pude visitar, ou me fiz conhecer pessoalmente. Não obstante, do Reno até o mar do Norte, do Elba ao Danúbio, nunca ouvi um "não"; a autoridade que vocês me confiaram se baseia absolutamente na livre vontade, contínua e suprema! (...) Em toda parte ouvi dos operários palavras que podem ser resumidas nesta frase: temos que forjar nossa vontade em um só instrumento e pôr esse instrumento em mãos de alguém cuja inteligência, caráter e boa vontade nos mereçam a devida confiança, para que possa usálo! Os dois extremos opostos, a liberdade e a autoridade, considerados até agora por nossos estadistas como inconciliáveis, e cuja conjunção era vista como a pedra filosofal - esses dois opostos mais radicais formaram um amálgama na nossa associação, que se converteu, assim, em modelo reduzido do que será nosso futuro modelo de sociedade! $!^{36}$

Mesmo após a morte de Lassalle em agosto de 1864, o partido continuou a cultuar o seu nome e a adotar os princípios inscritos no "Manifesto Operário", de maio de 1863. Seus sucessores na presidência, Bernhard Becker (entre 1864 e 1867) e Johann Baptist von Schweitzer (entre 1867 e 1871), conseguiram expandir a organização através do trabalho de divulgação e propaganda, no qual o jornal Sozialdemokrat teve um importante papel ${ }^{37}$.

Diante do personalismo difundido na Associação Geral dos Trabalhadores Alemães, Marx e Engels passaram a dirigir-lhe diversas críticas e a alertar para o "caminho falso" trilhado pela organização lassalleana. Esta, para Marx, "era, simplesmente, uma organização sectária - e, como tal, hostil à organização do verdadeiro movimento operário que a Internacional tem por objetivo criar" ${ }^{\prime 3}$. Ademais, o seu apego à política realista (Realpolitik) culminaria na acomodação à situação existente:

Acredito que Schweitzer, etc, agem de boa fé, mas são "políticos práticos". Querem levar em conta as circunstâncias existentes e não pretendem abandonar o privilégio da Realpolitik (...). Sabem que a imprensa operária e o movimento

\footnotetext{
${ }_{36}^{35}$ Lassalle, 1999, p.37.

${ }^{36}$ Discurso proferido por Lassalle em Ronsdorf, 22/5/1864 (Lassalle, 1999, p.244).

${ }^{37}$ Em 1864 possuía 4.600 membros, espalhados em 50 agrupamentos; já em 1875 este número chega a 15.322 membros (ibid, p.37).

${ }^{38}$ Carta de Marx a Bolte, de 23/11/1871 (MARX, ENGELS. Obras escolhidas. São Paulo: Alfa-Omega, v.3, 1980c, p. 265).
} 
operário na Prússia (e, em conseqüência, no resto da Alemanha), só existem por uma concessão da polícia. Querem, por isso, tomar as coisas como são, evitar provocar o governo, etc., da mesma forma que nossos políticos realistas "republicanos" estão dispostos a "tomar" um imperador da casa dos Hohenzollern"

As profundas divergências teóricas e práticas entre o grupo socialista e o lassalleano conduziram à fundação da Associação Internacional dos Trabalhadores, mais conhecida como a Primeira Internacional. A Internacional seria um prolongamento da tentativa de se criar uma Liga Comunista ${ }^{40}$, cujo objetivo principal residia no estabelecimento de "um ponto central de comunicação e de cooperação entre as sociedades operárias dos diferentes países que aspiram ao mesmo fim, a saber, o auxílio mútuo, o progresso e a completa libertação da classe trabalhadora" ${ }^{41}$.

Diferentemente da associação de Lassalle, a Internacional pregava que a emancipação da classe operária e a abolição de todo o regime de classes seria obtida através da luta dos próprios trabalhadores. O movimento político, portanto, é visto como meio para se atingir a solidariedade entre os trabalhadores de várias profissões e dos diversos países e a emancipação econômica da classe operária. Contudo, tal organização não estava livre de conflitos.

As divergências internas presentes na AIT a princípio não eram consideradas uma ameaça à sua constituição ${ }^{42}$. Ao contrário, a intenção de seus fundadores era criar uma organização democrática aberta a todos os trabalhadores, adeptos das mais diversas tendências. Esta iniciativa inédita tinha como objetivo fazer avançar a unidade e aglutinação das "multiformes divisões do trabalho" 43 que atuavam de maneira dispersa e isolada. Sendo assim, embora a Internacional desestimulasse as práticas conspirativas e sectárias de grupos operários, colocava como principal meta prepará-los para constituírem uma frente conjunta

\footnotetext{
${ }^{39}$ Ibid, p. 259.

${ }^{40}$ Cabe lembrar que esta foi extinta em 1852, dois anos após a cisão interna e expulsão da fração ultraesquerdista de Willich e Schapper, que defendiam a transformação da Liga em uma "sociedade de conspiradores" (cf. MARX, "La fraccion ultraizquierdista Willich-Schapper". In: De la Liga de los Justos al Partido Comunista. México: Roca, 1973, p.117-122).

41 Artigo $1^{\circ}$ do Estatuto da Primeira Internacional (MARX, Karl; ENGELS, F; LENIN, V. I. Critica do Programa de Gotha, Critica do Programa de Erfurt e Marxismo e Revisionismo. Porto: Portucalense, 1971, p.86).

${ }^{42}$ Cf. SANTOS, Ariovaldo. Marx, Engels e a luta de partido na Primeira Internacional (1864-1874). Londrina: UEL, 2002.

${ }^{43}$ Marx, apud Santos, 2002, p.25.
} 
em suas lutas pela emancipação, assumindo o papel de "instrumento de impulsão das lutas dos trabalhadores".

Neste sentido, a AIT não seria a "planta de estufa de uma seita ou de uma teoria" ou "obra de um punhado de políticos hábeis" ", mas sim uma organização que visava, a partir de um amplo e permanente debate entre uma pluralidade de tendências, delinear um campo de ação comum ${ }^{45}$, ou, nas palavras de Marx, "fundir em um só grande exército toda a classe operária combativa da Europa e da América"46.

Não obstante a abertura às múltiplas frações proletárias e aos vários matizes socialistas - sejam proudhonianos, lassaleanos, trade-unionistas, utópicos, etc. - e a utilização de uma tática conciliatória com vistas à preservação da unidade da organização, a inclusão de grupos sectários, como o dos bakuninistas, foi percebida como indesejável por ser capaz de fomentar a desagregação interna e, assim, retardar o projeto emancipatório. Consoante relembrou Marx, em carta a Bolte de 23 de novembro de 1871:

Em fins de 1868, o russo Bakunin ingressou na Internacional com o objetivo de criar, no seio da organização, e sob sua própria direção, uma segunda internacional chamada "Aliança da Democracia Socialista". Bakunin - homem sem qualquer conhecimento teórico - pretendia que esta organização particular representasse a propaganda científica da Internacional. (...) Seu programa era uma confusão superficial de retalhos mal alinhavados: igualdade entre classes (!), abolição do direito de herança como ponto de partida do movimento social (tolice saint-simoneana), o ateísmo como dogma obrigatório para os membros da Internacional, etc, - e, na qualidade de dogma principal, a abstenção (proudhoniana) face ao movimento político ${ }^{47}$.

A corrente anarquista de Bakunin sustentava que o sistema representativo, longe de ser uma garantia para o povo, criaria, ao contrário, a existência permanente de uma aristocracia governamental, que, por sua vez agiria contra o povo. Deste modo, o sufrágio universal seria

\footnotetext{
${ }^{44}$ Marx, apud Santos, 2002, p.8.

${ }^{45}$ Em carta a Sorge de 12-17/9/1874, Engels explicita a diversidade interna da organização: “A Internacional pertencia à época do Segundo Império, em que a opressão reinante em toda a Europa prescrevia ao movimento operário, que acabava de renascer, unidade e abstenção de toda polêmica interior. Era um momento em que os interesses cosmopolitas gerais do proletariado podiam passar a primeiro plano, um momento em que a Alemanha, Itália, Espanha e Dinamarca acabavam de incorporar-se ao movimento ou se estavam incorporando a ele. (...) o caráter teórico do próprio movimento era todavia muito confuso em toda a Europa, isto é, nas massas; o comunismo alemão não existia ainda como partido operário; o proudhonismo era demasiado débil para cavalgar sobre seus tópicos favoritos, e o novo discurso confuso de Bakunin não existia ainda nem na sua própria cabeça. Até os líderes das trade unions inglesas estimavam que o programa exposto nos considerandos dos Estatutos lhes oferecia uma base para ingressar no movimento" (Engels, apud Santos, 2002, p.27).

${ }^{46}$ Marx, apud, Santos, 2002, p.28.

${ }^{47}$ Marx; Engels, 1980c, p. 265.
} 
uma máscara por trás da qual "se esconde o poder realmente despótico do Estado, fundado sobre os bancos, sobre a polícia e sobre o exército", isto é, "um meio excelente para oprimir e para arruinar um povo em nome e sob o pretexto de uma vontade popular" 48 .

No entanto, Bakunin protestara contra o epíteto de "abstencionista", conferido por seus adversários, pois, a ser ver, o boicote das urnas consistiria em uma questão tática, e não de conteúdo. Assim, a renúncia a participar de eleições e a realizar alianças eleitorais com partidos radicais burgueses não significaria a rejeição da "política" em si, mas somente da política burguesa. Em contraste, defendia a insurreição de todo o povo, pela livre organização das massas trabalhadoras de baixo para cima. Logo, a realização do "socialismo antiautoritário", ou "libertário", proposto pelos anarquistas, exigiria a prévia e completa ruptura com todos os governos e formas de política burguesa.

A crítica dirigida por Bakunin ao "marxismo",49, predominante na Internacional, atribuía sua concepção de revolução e seu projeto de "ditadura do proletariado",50 a uma característica do temperamento do povo alemão, marcado pela "docilidade hereditária" e "sede de domínio". Segundo Bakunin, o alemão "é criado ao mesmo tempo para ser escravo e para dominar (...), aceita de bom grado a disciplina mais dura, mais vexatória, mais esmagadora; está mesmo pronto a amá-la desde que ela se coloque, ou, ainda, que ela coloque o Estado alemão acima de todos os outros e de todas as outras nações." ${ }^{.51}$.

Por esta razão, reinaria entre os alemães um sentimento entusiasta de triunfo nacional, político e militar, no qual se apoiariam, sobretudo, o poderio do Império pangermânico e seu chanceler, o príncipe Bismarck. Sendo o nacionalismo e o militarismo aspectos fundamentais do caráter do povo, estes sentimentos também atingiriam as massas e líderes operários, sob a forma de um "temor à revolução" que os orientaria à agitação dita pacífica e legal. Ao mesmo

\footnotetext{
${ }^{48}$ BAKUNIN, apud, GUÉRIN, Daniel; et allii. O anarquismo e a democracia burguesa. São Paulo: Editora Global, 1980, p.12.

${ }^{49}$ Concebido como o conjunto das teorias emanadas pelo próprio Marx.

50 Convém retomar a explicação de Eric Hobsbawm, concernente ao conceito de "ditadura do proletariado": "Nada indica que Marx tenha jamais usado o termo "ditadura" para indicar uma forma institucional específica de governo, mas tão somente para definir o conteúdo, mais que a forma assumida pelo domínio de um grupo de uma classe. No seu entender a "ditadura" da burguesia podia existir indiferentemente com ou sem o sufrágio universal. É todavia possível que numa situação revolucionária um tal governo tenda a assumir formas mais abertamente ditatoriais; aí o principal objetivo do novo regime proletário não pode ser senão o de ganhar tempo, adotando as medidas necessárias a intimidar a burguesia" (HOBSBAWM. "Aspectos políticos de transição do capitalismo ao socialismo". In: História do marxismo I: o marxismo no tempo de Marx. Rio de Janeiro: Paz e Terra, 1987, p.311-312). Desta forma, o autor argui que não há um modelo universalmente aplicável de forma da ditadura do proletariado.

${ }^{51}$ BAKUNIN, Mikhail. Estatismo e anarquia. São Paulo: Editora Imaginário, 2003, p.225.
} 
tempo, esta ação dirigida à atividade parlamentar serviria como válvula de escape para o Estado alemão, sendo útil para a conservação e legitimação do seu poder ${ }^{52}$.

Partindo destas considerações, Bakunin conclui:

Enfim, é impossível esperar uma revolução na Alemanha, pelo menos porque há, na realidade, no espírito, no caráter e no temperamento do alemão, pouquíssimos elementos revolucionários. O alemão refletirá o quanto quiser contra todo representante da autoridade, mesmo contra o imperador. Nunca acabará de refletir; mas, mesmo esta disposição de espírito, volatilizando, se se pode dizer, suas forças morais e cerebrais, e impedindo-o de se voltar para si mesmo, protege-o contra o perigo de uma explosão revolucionária ${ }^{53}$.

Por conseguinte, Bakunin via o socialismo científico como a defesa de um governo despótico das massas proletárias por uma nova e muito restrita aristocracia de verdadeiros ou pretensos doutos ${ }^{54}$. Neste sentido, Bakunin repudiara categoricamente a possibilidade de aliança com o recém-formado Partido Social-Democrata dos Trabalhadores Alemães:

Preservar-nos-emos de incitar nossos irmãos de origem a ingressar nas fileiras do Partido Social-Democrata dos Trabalhadores Alemães, à frente do qual se encontram, antes de tudo, sob espécie de um duunvirato investido de poderes ditatoriais, os Srs. Marx e Engels, e atrás deles, ou abaixo deles, os Srs. Bebel, Liebknecht e alguns judeus encarregados dos trabalhos literários; dedicar-nos-emos, ao contrário, com todas as nossas forças, a desviar o proletariado eslavo de uma aliança com este partido, de modo algum popular, mas por sua tendência, seus objetivos e seus meios puramente burgueses e, além do mais, alemão, por exclusividade, o que seria mortal para os eslavos ${ }^{55}$.

É interessante notar que Engels também havia analisado em vários escritos a inclinação alemã à disciplina e ao "espírito militar" França", redigido em 18 de março de 1891, o autor retomou o assunto ressaltando a necessidade de se abolir o "velho poder estatal" e substituí-lo por outro verdadeiramente democrático. Para tanto, Engels adverte que a Alemanha é um país em que:

a fé supersticiosa no Estado se transplantou do campo filosófico para a consciência comum da burguesia e mesmo de numerosos operários. Segundo a concepção filosófica, o Estado é a "realização da Idéia", ou seja, traduzido em linguagem

\footnotetext{
52 Ibid, p. 227.

${ }^{53}$ Ibid, p. 229.

${ }^{54}$ Ibid, p. 213.

55 Ibid, p.75.

${ }^{56}$ Cf. ENGELS, “The Prussian military question and the German Worker's Party (1862)”. In: www.marxists.org.
} 
filosófica, o reino de Deus sobre a terra, o terreno em que se tornam ou devem tornar-se realidade a eterna verdade e a eterna justiça. Surge daí uma veneração supersticiosa do Estado e de tudo o que com ele se relaciona, veneração supersticiosa que se vai implantando na consciência com tanto maior facilidade quando as pessoas se habituam, desde a infância a pensar que os assuntos e interesses comuns a toda a sociedade não podem ser regulados nem defendidos senão como tem sido feito até então, isto é, por meio do Estado e de seus bem pagos funcionários. $^{57}$

Neste mesmo texto, Engels observa que já teria sido dado um passo enormemente audaz ao "libertar-se da fé na monarquia hereditária e manifestar-se entusiasmo pela República democrática". Não obstante, sublinha que o Estado "não é mais do que uma máquina para a opressão de uma classe por outra, tanto na República democrática como sob a monarquia; e, no melhor dos casos, um mal que se transmite hereditariamente ao proletariado triunfante em sua luta contra a dominação de classe”. Sendo assim, o proletariado vitorioso não poderia deixar de "amputar imediatamente, na medida do possível, os aspectos mais nocivos desse mal, até que uma futura geração, formada em circunstâncias sociais novas e livres, possa desfazer-se de todo esse velho traste do Estado" ${ }^{58}$.

Como foi visto, a crítica formulada por Marx e Engels ao Estado não é menos severa e contundente do que a endereçada por Bakunin. Contudo, as divergências em relação à tática empregada distanciaram significativamente os dois grupos dentro da Internacional. Em discurso à Conferência da Primeira Internacional, de 21 de setembro de 1871, Engels explicitou tais diferenças:

\footnotetext{
${ }^{57}$ MARX, ENGELS. Obras escolhidas. São Paulo: Alfa-Omega, v.2, 1980b, p. 51.

${ }^{58}$ Ibid.
}

Para nós, a abstenção é inviável. O partido operário já existe como partido político, na maioria dos países, e não seremos nós que o destruiremos, pregando a abstenção. A experiência da vida atual, a opressão política a que os governos existentes submetem os trabalhadores (tanto com objetivos políticos como sociais) obriga-os a se dedicarem, querendo ou não, à política. Pregar a abstenção política aos operários significa lançá-los aos braços da política burguesa. (...) Todos os abstencionistas se pretendem revolucionários, e até revolucionários por excelência. Mas a revolução é a suprema ação política: quem a deseja deve desejar o que a viabiliza, a ação política que a prepara, que propicia aos operários a educação revolucionária, sem a qual, no dia seguinte ao da luta, eles serão enganados pelos Favre e pelos Pyat. Contudo, a política a que devem dedicar-se os trabalhadores é a política operária. O partido operário não pode constituir-se como apêndice de um partido 
burguês qualquer, mas como partido autônomo, com objetivo e política próprios. As liberdades políticas, o direito de reunião e associação e a liberdade de imprensa - estas são as nossas armas. Deveremos cruzar os braços e abstermo-nos quando nos queiram tirá-las? Diz-se que toda ação política implica o reconhecimento do estado de coisas existente. Mas quando esse estado nos proporciona meios para lutar contra ele, recorrer a tais meios não significa legitimar o status quo ${ }^{59}$.

Como resultado dos intensos e calorosos debates levadas a cabo no curso do ano de 1872 os anarquistas foram expulsos da Associação Internacional dos Trabalhadores. Convém ressaltar que em carta a Bebel de 1873, Engels explicitou que a cisão da Internacional e a exclusão dos anarquistas não deveriam ser concebidas como um enfraquecimento do movimento operário; ao contrário:

já dizia o velho Hegel que um partido mostra que é o vitorioso, na medida em que se divide e consegue suportar a divisão. $\mathrm{O}$ movimento proletário passa, necessariamente, por diferentes fases de desenvolvimento; em cada uma dessas fases há sempre uma parte de seus componentes que se emaranha e fica no caminho. Esta é a única razão por que, na prática, a "solidariedade do proletariado" se realiza, em toda parte, em diferentes grupos do partido que travam entre si uma luta de vida ou morte, como no caso das seitas cristãs do império romano, no período das piores perseguições ${ }^{60}$.

Com a exclusão dos anarquistas, consagrava-se entre os socialistas do ocidente o formato organizacional e o paradigma programático adotados pelo Partido Social-Democrata dos Trabalhadores Alemães, criado em 1869 por Wilhelm Liebknecht (1826-1900) e August Bebel (1840-1913) ${ }^{61}$.

Em panfleto distribuído para o Congresso de Eisenach, na ocasião de fundação do partido, Liebknecht expressava um posicionamento revolucionário e crítico em relação à participação eleitoral:

O socialismo não é uma questão de teoria: é simplesmente uma questão de força que não pode ser resolvida no Parlamento, apenas no campo de batalha, como qualquer outra questão de força... Para os povos como para os príncipes a violência tem a última palavra. (...) sem dúvida o sufrágio universal é um direito sagrado do povo e uma condição fundamental do Estado democrático socialista - do Estado democrático socialista - ,

\footnotetext{
${ }^{59}$ ENGELS. "Friedrich Engels: Política”. José Paulo Netto [org]. In: Coleção Grandes Cientistas Sociais, n. 17, São Paulo: Ática, 1981, p.100-101.

${ }^{60}$ MARX, ENGELS. Obras escolhidas. São Paulo: Alfa-Omega, v.3, 1980c, p.274.

${ }^{61}$ Neste mesmo ano o Partido Progressista racha devido ao dissenso quanto à unificação alemã: a ala direita do partido constituiu o Partido Nacional-Liberal, oferecendo apoiou à unificação sob o comando da Prússia.
} 
mas considerado à parte, separado da liberdade civil, sem liberdade de imprensa, sem direito de associação, sob a dominação dos sabres dos policiais e dos soldados, e, em uma palavra, dentro do Estado absolutista, o sufrágio universal só pode ser o joguete e instrumento do absolutismo ${ }^{62}$.

O programa do partido (Sozialdemokratische Arbeiterpartei Eisenacher Programms) aprovado no Congresso de Eisenach, em agosto de 1869, refletia igualmente tal duplicidade, ou seja, a combinação do objetivo revolucionário com a demanda pela conquista das liberdades civis, de modo a atrair, simultaneamente, elementos marxistas e radicalistas burgueses. Destarte, o programa dividia-se em uma parte teórica, isto é, uma exposição de princípios, e uma parte prática, com um programa de ação.

Malgrado a influência exercida pela teoria marxista - colocando-se em primeiro plano a luta pela igualdade dos direitos e dos deveres mediante a supressão de qualquer dominação de classe - o programa trazia em seu texto fórmulas vagas ou controversas, como, por exemplo, a pretensão de estabelecer um "Estado popular livre", ou a idéia de restituir ao trabalhador o "produto integral do seu trabalho". Além disto, estabelecia que a liberdade política seria a "condição mais indispensável da emancipação das classes trabalhadoras", de forma que a solução da questão social estaria subordinada à solução da questão política, pela institucionalização de um Estado democrático ${ }^{63}$.

\footnotetext{
${ }^{62}$ COLE, George Douglas Howard. Historia del pensamiento socialista: la segunda internacional: 1889- 1914. México: Fondo de Cultura Economica, v.1, 1959, p.243.

${ }^{63}$ A parte teórica do Programa de Eisenach dispunha: "I- O Partido Operário Social-Democrata pretende estabelecer o Estado popular livre. II- Todo o membro do Partido Operário Social-Democrata se compromete a defender com todas as suas forças os seguintes princípios: 1- As presentes condições políticas e sociais são altamente injustas; convém, portanto, combatê-las com a maior energia. 2- A luta pela emancipação das classes trabalhadoras não é uma luta com vista a privilégios e monopólios, mas uma luta pela igualdade dos direitos e dos deveres e pela supressão de qualquer dominação de classe. 3- A dependência econômica em relação ao capitalismo constitui, para o trabalhador, a base da servidão em todas as suas formas; a social-democracia procura dar a cada trabalhador o produto integral do seu trabalho, pela abolição do modo de produção atual (assalariado) e pela organização do trabalho numa base cooperativa. 4- A liberdade política é a condição mais indispensável da emancipação das classes trabalhadoras. Portanto, o problema social é inseparável do problema político; a solução do primeiro está ligada à solução do segundo e só é possível num Estado democrático. 5Considerando que a emancipação política e econômica da classe operária só é possível se esta travar a luta solidária e unida, o Partido Operário Social-Democrata dá-se uma organização uniforme, mas deixa a todos e a cada um a liberdade de fazer a sua influência para o bem da comunidade. 6- Considerando que a emancipação do trabalho não é nem um problema local nem um problema nacional, mas antes um problema social que abrange todos os países civilizados, o Partido Social-democrata, na medida em que lho permitem as leis sobre as associações, declara formar um ramo da Associação Internacional dos Trabalhadores, e declara prosseguir o mesmo objetivo que esta (MARX, Karl; ENGELS, F; LENIN, V. I. Critica do Programa de Gotha, Critica do Programa de Erfurt e Marxismo e Revisionismo. Porto: Portucalense, 1971, p. 89-91).
} 
Embora se apresentasse como um braço da Internacional ${ }^{64}$, o Partido SocialDemocrata dos Trabalhadores Alemães demonstrava um forte viés reformista. Desde a sua criação a ênfase concedida à via legal e às reivindicações imediatas era evidente ${ }^{65}$.

Tal orientação tornou-se ainda mais clara com a aprovação, no Congresso de Stuttgart de 1870, de uma resolução segundo a qual o Partido de Eisenach deveria não apenas tomar parte nas eleições para o Reichstag por razões de propaganda, como também no intuito de participar das decisões parlamentares "pelo bem da classe trabalhadora". Todavia, de acordo com a resolução, o partido deveria manter, em geral, uma atitude negativa frente ao trabalho do Parlamento, além de não participar de nenhuma aliança nem aceitar qualquer compromisso com outros partidos ${ }^{66}$.

A participação dos representantes do partido no Parlamento, no entanto, viu-se prejudicada com o advento da Guerra Franco-Prussiana em 1870. Os protestos de Liebknecht e Bebel contra a guerra e a anexação da Alsácia-Lorena renderam-lhes duas condenações por incitação à alta-traição, sendo sentenciados a penas de quatro anos de prisão. $\mathrm{O}$ recrudescimento da repressão a greves e manifestações e a crise econômica deflagrada em 1873 tiveram por efeito a aproximação entre o partido lassalleano e o partido eisenachiano, no início da década de 70. Assim, foi iniciado um movimento pela unificação das duas organizações operárias.

Mesmo reconhecendo a situação adversa enfrentada pelo partido, Marx e Engels mostravam-se receosos em relação à recepção de grupos lassalleanos, considerando-os uma ameaça em potencial de desfiguração e descaracterização do partido. Em carta a Bebel de 20

\footnotetext{
${ }^{64}$ A organização do Partido Social-Democrata dos Trabalhadores Alemães seguia o modelo organizacional da AIT, contando com um Comitê (Ausschuss) eleito, uma Comissão de Controle e uma Assembléia Geral (GAY, Peter. The dilemma of democratic socialism. New York: Columbia University Press, 1970, p.114).

${ }^{65}$ A parte prática do Programa de Erfurt dispunha: "III- Entre as reivindicações mais urgentes que o Partido Operário Social-Democrata deve tomar como objeto de uma viva agitação, têm que citar as seguintes: 1Sufrágio universal, igual, direto e secreto concedido a todos os homens de vinte anos, para as eleições para o Parlamento, os Landtags, as Assembléias provinciais e municipais e todos os outros corpos representativos. Os representantes eleitos receberão emolumentos suficientes. 2- Legislação direta (atribuição ao povo do direito de propor e rejeitar as leis). 3- Supressão de todos os privilégios de classe, de propriedade, de nascimento e de culto. 4- Substituição do exército permanente por uma milícia popular. 5- Separação da Igreja e do Estado, e separação da escola e da Igreja. 6- Instrução obrigatória nas escolas populares e instrução gratuita em todos os estabelecimentos de instrução pública. 7- Independência dos tribunais, criação do júri e de jurisdições profissionais para cada ramo de indústria, processo público e verbal; gratuidade da justiça. 8- Revogação de todas as leis sobre a imprensa, sobre o direito de reunião e de coligação; introdução do dia de trabalho normal; limitação do trabalho das mulheres, proibição do trabalho das crianças. 9- Supressão dos impostos indiretos, imposto direto único e progressivo sobre o rendimento e as heranças. 10- Apoio dado pelo Estado ao movimento cooperativo, créditos especiais afetados pelo Estado às associações livres de produção, sob certas garantias democráticas" (MARX, Karl; ENGELS, F; LENIN, V. I. Critica do Programa de Gotha, Critica do Programa de Erfurt e Marxismo e Revisionismo. Porto: Portucalense, 1971, p. 89-91).

${ }^{66}$ PRZEWORSKI, Adam. Capitalismo e social-democracia. São Paulo: Companhia das Letras, 1989, p.22.
} 
de junho de 1873, Engels manifestara sua preocupação de que uma atitude conciliatória pudesse conduzir ao sacrifício dos princípios socialistas:

É necessário não se deixar enganar pelos gritos de "unidade". Precisamente os que mais abusam desta palavra-de-ordem são os primeiros a provocar dissensões (...). É natural que todo organismo dirigente do Partido procure êxitos em seu trabalho. Há, porém, circunstâncias em que é necessário ter a coragem de renunciar aos êxitos imediatos em benefício de coisas mais importantes. Isso é verdade particularmente para um partido como o nosso, cuja vitória final está plenamente assegurada e cujo crescimento, em nossa época e ante nossos próprios olhos, tem sido tão grandioso. Um partido assim não necessita sempre e em todas as condições conquistar êxitos imediatos ${ }^{67}$.

Assim, de acordo com Engels, embora o movimento proletário estivesse passando por uma fase conturbada, o partido não deveria ter em mira "arrebatar, aqui e ali, alguns grupos de militantes ao adversário", mas sim, "influenciar as grandes massas que ainda não se incorporaram ao movimento". Deste modo, evitar-se-ia que fossem trazidos ao partido as vicissitudes das concepções lassalleanas ${ }^{68}$.

Não obstante as várias advertências de Marx e Engels, em maio de 1875 foi realizado o Congresso de Gotha, no qual foi aprovada a fusão entre os dois partidos. Compareceram ao congresso 56 delegados marxistas (que representavam 9.121 membros) e 74 delegados lassalleanos (representando 15.322 membros) ${ }^{69}$. Deste modo, fundaram o Partido Socialista dos Trabalhadores da Alemanha (Sozialistische Arbeiterpartei Deutschlands), dirigido por um Executivo (Vorstand) eleito por um Congresso Geral, por maioria simples, além de uma Comissão de Controle (Ausschuss) composta por dezoito membros ${ }^{70}$.

Nesta mesma ocasião foi aprovado o novo programa do partido, conhecido como o Programa de Gotha. O conteúdo do programa tornava clara a tentativa de conciliação entre as duas frações do partido, incorporando princípios lassalleanos e as reivindicações práticas esboçadas no Programa de Eisenach. Poucos meses antes da unificação, em carta a Bebel de 18 de março de 1875, Engels havia prevenido o partido para a necessidade de se receber os lassalleanos "da maneira mais fria", e, assim, "testemunhar-lhes a maior desconfiança". Para Engels, os lassalleanos deveriam mostrar-se dispostos a abandonar as suas palavras de ordem sectárias e os seus pedidos de ajuda ao Estado, aceitando, nos pontos essenciais, o Programa

\footnotetext{
${ }^{67}$ MARX, ENGELS. Obras escolhidas. São Paulo: Alfa-Omega, v.3, 1980c, p.273.

${ }^{68}$ Ibid, p. 272.

${ }^{69}$ LASSALLE, Ferdinand. Manifesto operário e outros textos. Brasília: Instituto Teotônio Vilela, 1999, p.75.

${ }^{70}$ GAY, Peter. The dilemma of democratic socialism. New York: Columbia University Press, 1970, p.115.
} 
de Eisenach de 1869, ou uma nova edição deste, corrigida conforme as circunstâncias presentes $^{71}$.

Contudo, de acordo com Engels, o projeto de programa apresentado pelo partido provaria que, "se a nossa gente é teoricamente muito superior aos chefes lassalleanos, quanto à habilidade política fica muito abaixo deles. Os "honestos" conseguiram mais uma vez deixar-se cruelmente levar pelos desonestos" ${ }^{72}$. Assim, em carta a Bracke, de 11 de outubro de 1875, Engels recriminou Liebknecht pela incorporação de "frases e palavras de ordem de Lassalle", "banais reivindicações democráticas" e "imbecilidades horripilantes de teses pretensamente comunistas". Segundo o autor, "Liebknecht estragou tudo na sua ânsia de ver a unidade realizada, de lá chegar a qualquer preço"; por conseguinte a unidade entre as duas organizações traria em si o germe da futura cisão ${ }^{73}$.

Marx apresentou igualmente sua insatisfação, em carta a Bracke, de 5 de maio de 1875, ao considerar o programa "absolutamente condenável”. Para Marx o programa desmoralizaria o partido, ao instituir uma "barganha de princípios":

Pretendia-se manifestamente escamotear toda a crítica e banir toda a reflexão do nosso próprio partido. É sabido que o simples fato da unificação traz satisfação aos operários, mas engana-se quem pensar que este resultado imediato não se paga demasiado caro. ${ }^{74}$

Marx aprofundou sua crítica em uma carta circular aos dirigentes do partido, posteriormente publicada sob o título "Crítica ao Programa de Gotha" - em 1891. Em sua carta, Marx chamava a atenção para a utilização de uma fraseologia burguesa e lassalleana no novo programa. Assim, o programa estaria permeado de afirmações como "o trabalho é a fonte de toda a riqueza", ou concepções estranhas ao socialismo, tais como "produto integral do trabalho", "direito igual", "repartição eqüitativa", "lei de bronze do salário" e "Estado Livre" 75 .

\footnotetext{
${ }^{71}$ MARX, Karl; ENGELS, F; LENIN, V. I. Critica do Programa de Gotha, Critica do Programa de Erfurt e Marxismo e Revisionismo. Porto: Portucalense, 1971, p. 68.

72 Ibid.

${ }^{73}$ Ibid, p.75.

${ }^{74}$ Marx;Engels, 1980c, p.10.

${ }^{75}$ O Programa de Gotha, de maio de 1875, dispunha: "I- O trabalho é a fonte de toda riqueza e de toda a cultura e como, em geral, o trabalho produtivo só é possível pela sociedade, o seu produto integral pertence à sociedade, quer dizer, a todos os membros desta, devendo todos participar no trabalho, em virtude de um direito igual, recebendo cada um segundo as suas necessidades razoáveis. Na sociedade atual, os meios de trabalho são monopólio da classe capitalista; o estado de dependência que daí resulta para a classe operária é a causa da miséria e da servidão em todas as suas formas. A libertação do trabalho exige a transformação dos instrumentos de trabalho em patrimônio comum da sociedade e a regulamentação do trabalho coletivo pela comunidade, com
} 
Como resultado, o programa teria aderido a um socialismo vulgar que tomaria a repartição como uma esfera independente do modo de produção e abandonaria qualquer referência à necessidade de supressão das diferenças de classe. Destarte, em lugar da defesa de um processo de transformação revolucionária da sociedade, tal programa pretenderia que a "ajuda do Estado" conduziria à "organização socialista do conjunto do trabalho"; isto é, que o fomento das cooperativas de produção pelo Estado levaria à construção de uma nova sociedade. Para Marx este tipo de afirmação não teria base, posto que a derrubada das condições de produção capitalistas não teriam relação alguma com a criação de sociedades cooperativas subvencionadas pelo Estado. Neste sentido, as sociedades cooperativas só teriam valor enquanto criações independentes nas mãos dos trabalhadores, não sendo protegidas nem por governos nem por burgueses ${ }^{76}$.

Ademais, Marx lançou luz à tentativa lassalleana de "dissimular a sua aliança com os absolutistas e feudais contra a burguesia”, na medida em que reúne todos os adversários da classe operária em "uma mesma massa reacionária”. Em síntese, Marx realiza uma crítica contundente à vinculação do movimento operário ao Estado e à ilusão de que através da negociação com o governo poder-se-ia introduzir mudanças substanciais na ordem vigente. Assim, visto que o Estado alemão não passaria de um "despotismo militar, com uma armadura burocrática e blindagem policial, adornado de formas parlamentares, com misturas de elementos feudais e de influências burguesas", a idéia de uma "monarquia social" deveria ser descartada:

A própria democracia vulgar, que vê na república democrática o advento do reino milenar e que não tem a menor suspeita de que é precisamente sob esta última forma de Estado da sociedade burguesa que se travará a suprema batalha entre as classes, a própria democracia está ainda mil vezes acima de um

afetação de uma parte do produto às necessidades gerais e distribuição eqüitativa do restante. A libertação do trabalho deve ser obra da classe operária em face da qual todas as outras classes não formam mais que uma massa reacionária. II- Partindo desses princípios, o Partido Operário Socialista da Alemanha esforça-se, por todos os meios legais, por fundar o Estado livre e a sociedade socialista, por quebrar a lei de bronze dos salários pela destruição do sistema do trabalho assalariado, por abolir a exploração em todas as suas formas, por eliminar toda a desigualdade social e política. O Partido Operário Socialista da Alemanha, apesar de agir em primeiro lugar no quadro nacional, tem consciência do caráter internacional do movimento operário e está resolvido a cumprir todos os deveres que esse fato impõe aos trabalhadores com vista à realização da fraternidade de todos os homens. O Partido Operário Socialista da Alemanha reclama, para preparar as vias para a solução da questão social, o estabelecimento de sociedades operárias de produção com a ajuda do Estado, sob o controle democrático do povo trabalhador. As sociedades de produção devem ser suscitadas na indústria e na agricultura com tal amplitude que delas resulte a organização socialista do conjunto do trabalho." (Marx; Engels; Lenin, 1971, p. 91-93).

${ }^{76}$ Ibid, p. 28. 
democratismo deste gênero, confinado aos limites do que é autorizado pela polícia e proibido pela lógica (grifo nosso). ${ }^{77}$

Cabe acrescentar que as críticas de Marx e Engels não foram bem recebidas pelos dirigentes do novo partido. O texto da "Crítica ao Programa de Gotha" somente foi divulgado oito anos após a morte de Marx, em 1891, devido à iniciativa e insistência de Engels. Neste meio tempo, Marx e Engels não cessaram de se contrapor ao conteúdo do programa e à influência da figura de Lassalle dentro do partido ${ }^{78}$.

Como Engels havia previsto, a busca pelo êxito imediato prevaleceu sobre a salvaguarda dos princípios socialistas. A reputação de Lassalle e seus méritos de agitador continuaram sendo exaltados no interior do movimento no intuito de atrair a massa dos trabalhadores, ainda dispersa e avessa a questões de ordem política. Como conseqüência, o Partido Socialista dos Trabalhadores da Alemanha sofreu uma significativa expansão, até ser colocado na clandestinidade pelas leis anti-socialistas de Bismarck. Contudo, seu crescimento não conseguiu abafar os conflitos internos latentes, que Engels já identificara na ocasião de sua fundação, conforme veremos mais adiante.

\section{2- A repressão e a reestruturação do movimento}

A década de 1870 teve início na Alemanha com a vitória do projeto militarista e expansionista das elites conservadoras. Sob a liderança de Bismarck, Primeiro Ministro da Prússia a partir de 1862, foi concretizado o processo de unificação nacional, que o havia motivado desde seu ingresso no governo de Guilherme I, como explicitara na ocasião:

As fronteiras da Prússia são exíguas e não convém a um Estado de primeira ordem. Para conquistar novas fronteiras é preciso desenvolver e aperfeiçoar a organização militar. É necessário preparar-se para um conflito próximo e, enquanto aguardamos, reunir e aumentar nossas forças. O erro cometido em 1848 foi o de querer fazer da Alemanha um único Estado por meio de instituições populares. Os grandes problemas nacionais não são resolvidos pelo direito, mas pela força; a força tem sempre primazia sobre o direito ${ }^{79}$.

\footnotetext{
${ }^{77}$ Ibid, p. 31.

${ }^{78}$ Engels, em carta a Bracke, de 11/10/1875, afirmou: "Felizmente o programa teve uma apreciação mais favorável do que merecia. Operários, burgueses e pequeno-burgueses lêem nele o que verdadeiramente lá devia estar e não o que efetivamente lá está; e nem sequer ocorreu a ninguém examinar publicamente o conteúdo real de uma dessas maravilhosas frases. Isso permitiu-nos ficar calados” (Ibid, p.76).

${ }^{79}$ Discurso de Bismarck de 1862 (Bakunin, 2003, p. 205).
} 
A unificação do país recebeu o apoio das elites aristocráticas locais e da burguesia, atraída, sobretudo, pelas grandes perspectivas de expansão comercial abertas pela abolição das barreiras econômicas. Assim, a fase conhecida como Gründerzeit ("período dos fundadores") foi caracterizada pelo desenvolvimento de uma "modernização conservadora" 80 , impulsionada simultaneamente pelo Estado e pelas elites econômicas do campo e da cidade.

Acompanhando o processo de expansão comercial e industrial, verificou-se ainda o incentivo à produção em diversas áreas como nas artes, ciências, imprensa e educação ${ }^{81}$. As cidades expandiram, juntamente com o número de serviços e a infra-estrutura urbana. Deste modo, à medida que crescia economicamente e emergia como uma das principais potências da Europa continental, a Alemanha foi estendendo seu poder e influência cultural.

O Kaiserreich, marcado pelo espírito militar e autoritário da aristocracia agrária, prosseguiu sua política belicista e anexionista, após a consolidação da unidade alemã. Bismarck, na qualidade de chanceler do Reich (de 1871 a 1890), promoveu uma complexa política de alianças ao longo da década de 1880 que o colocou em uma difícil posição diante das demais potências ${ }^{82}$. Ademais, criavam-se as condições para a implementação de uma política colonialista direcionada para territórios na África, em Nova Guiné e no Pacífico.

A força e o poderio do Império - constituído como uma federação das dinastias reinantes - traduziam-se, igualmente, na concentração do poder político interno. A nova constituição, aprovada pelo Reichstag em 1871, representava a extensão da constituição da Confederação Germânica do Norte (1866), agora abarcando 25 Estados e Alsácia-Lorena ${ }^{83}$. Diferentemente do esboço preparado pela Assembléia Constituinte de Frankfurt de 1849 posteriormente dissolvida -, tal constituição não possuía uma carta de direitos fundamentais.

Segundo o texto constitucional, o rei da Prússia - e Imperador Germânico - seria o chefe das forças armadas (exército e marinha), trataria de assuntos externos e nomearia o

\footnotetext{
${ }^{80}$ Cf. MOORE Jr. Barrington. As origens da ditadura e da democracia. São Paulo: Martins Fontes, 1983.

${ }^{81}$ Cf. MAYER, Arno J. A força da tradição. São Paulo: Companhia das Letras, 1987.

${ }^{82}$ Em 1882 fez parte da Tripla Aliança, com Áustria e Itália, que obrigava a declarar apoio em casos de guerra com a Rússia (pelos Bálcans e a Bósnia Hezergovina), a França (Alsácia-Lorena, Roma) e a Inglaterra.

${ }^{83}$ O Kaiserreich era um Estado federal, formado por 25 Länder: desde a Prússia, com mais de metade da população e a totalidade dos recursos naturais e da metalurgia, até os pequenos principados de 50 mil habitantes, passando pela Baviera, Saxônia e Württemberg, com alguns milhões de habitantes, mais as três "cidades livres" de Hamburgo, Bremen e Lübeck, cada um com a sua constituição. Prússia tinha rei, Baviera, Saxônia e Württemberg também, Baden e Hesse, grão-duques; cidades livres tinham Senado. Embora a legislação imperial estivesse acima da estadual, os Estados deteriam controle de seu Judiciário, da polícia, da taxação local, da política educacional, das igrejas, das ferrovias e dos correios.

(Cf. LOUREIRO. A Revolução Alemã, 1918 - 1923. São Paulo: UNESP, 2005).
} 
chanceler imperial e o gabinete ministerial. Outrossim, instituía-se um sistema bicameral, no qual o Bundesrat (Conselho Federal) - composto por representantes nomeados pelos respectivos Estados $^{84}$ - aprovaria a declaração de guerra, a dissolução do Reichstag e a intervenção em Estados (exceto na Baviera). Já o Reichstag ${ }^{85}$ - cujos membros eram eleitos por cinco anos em eleições diretas por meio de sufrágio universal masculino ${ }^{86}$ - seria responsável pela aprovação do orçamento e das leis referentes à jurisdição federal (exército, marinha, impostos e taxas, indústria, comércio e comunicação, finanças, patentes, pesos e medidas, censura, leis civis e criminais, etc.).

Cabe salientar, no entanto, que os poderes do Reichstag eram consideravelmente limitados. Além de não poder propor leis nem poder votá-las sem a concordância do Bundesrat, o Reichstag estava sob permanente ameaça de dissolução, pois poderia ser fechado ao arbítrio do governo, quando, então, seriam convocadas novas eleições. Assim, o Parlamento - única instituição "unitária” representativa do povo alemão - não detinha controle efetivo sobre o Executivo, não possuindo poderes para destituir o Chanceler, que apenas respondia ao Imperador (Kaiser). Deste modo, a impotência política do Parlamento converteu-o em um mero fórum de discussões, com uma atuação política restrita à crítica, pressão e à aprovação de projetos de lei.

Max Weber, em sua análise do "período bismarckiano", publicada em junho de 1917 sob o título "Parlamentarismo e governo numa Alemanha reconstruída", enfatizou a necessidade de ampliação do escopo do Parlamento através da outorga de poderes de fiscalização, como, por exemplo, o direito de instaurar inquéritos parlamentares. Segundo Weber, o Parlamento somente seria eficaz na medida em que contribuísse para a publicidade e supervisão da administração. Ademais, consoante o autor, como os líderes políticos não conseguiriam encontrar sua vocação no parlamento e nos partidos - e o Executivo, por sua vez, estaria nas mãos de burocratas que não seriam líderes partidários e nem estariam em contato permanente com os partidos - o "patronato parlamentar" favoreceria a prevalência da mediocridade na esfera política ${ }^{87}$.

\footnotetext{
${ }^{84}$ Dos 58 assentos a Prússia exercia o controle sobre 20 deles. Era necessário o veto de 14 membros para impedir a aprovação de emendas constitucionais (Cf. RODES, John E. Germany: a history. New York: Holt, Rinehart and Winston, 1964).

${ }^{85}$ Dos 397 assentos do Reichstag, 235 eram prussianos. Convém lembrar que até 1906 seus membros não eram remunerados (Cf. Rodes, 1964).

${ }^{86}$ Homens maiores de 25 anos.

${ }^{87}$ WEBER, Max. "Parlamentarismo e governo numa Alemanha reconstruída: uma contribuição à crítica política do funcionalismo e da política partidária”. In: Coleção Os pensadores. São Paulo: Abril Cultural, 1974, p.52.
} 
Com efeito, o Parlamento não passaria de um "carimbo involuntariamente tolerado de uma burocracia dominante", caracterizado pela dependência política, impotência e baixo nível intelectual de seus membros ${ }^{88}$ :

só um Parlamento ativo e não um Parlamento onde apenas se pronunciam arengas pode proporcionar o terreno para $\mathrm{o}$ crescimento e ascensão seletiva de líderes genuínos, e não meros talentos demagógicos. Um Parlamento ativo, entretanto, é um Parlamento que supervisiona a administração participando continuamente do trabalho desta ${ }^{89}$.

Considerando que a participação seria precondição para o desenvolvimento do discernimento político, Weber asseverou que a Alemanha não encontrou condições propícias para desenvolver uma tradição política. Neste sentido, a nação estaria desacostumada a participar da resolução de seus assuntos políticos através de seus representantes eleitos e estaria despreparada para considerar criticamente as qualificações de seus representantes. Assim, Weber destacara que o legado que Bismarck deixou atrás de si foi "uma nação sem qualquer sofisticação política" e "sem qualquer vontade política própria" por estar acostumada à idéia de que o grande estadista ao leme tomaria as decisões políticas necessárias". ${ }^{90}$

O caráter conservador do governo imperial ficou ainda mais evidente a partir da outorga de leis anti-socialistas, em 1878, que tornaram o Partido Socialista dos Trabalhadores Alemães uma organização clandestina. A "política de ferro e sangue” adotada pelo governo, sob o comando de Bismarck, com o apoio da burguesia ${ }^{91}$, já vinha sendo colocada em prática na perseguição a católicos, durante a Kulturkampf ${ }^{92}$, sobretudo no período de 1872 a 1887 . Assim como o governo tentou vincular o Partido do Centro à tentativa de assassinato de Bismarck - perpetrada por Kullmann (um tanoeiro desempregado e católico) em julho de 1874 - para justificar a promulgação de leis anti-católicas, a mesma estratégia foi aplicada em relação aos social-democratas.

\footnotetext{
${ }^{88}$ Ibid, p. 21.

${ }^{89}$ Ibid, p.44.

${ }^{90}$ Ibid, p. 20.

91 "Os nacionais-liberais estavam dispostos a fazer mais do que concessões a Bismarck, e mesmo os progressistas concordavam que se tomassem medidas no sentido de que se constituísse em delito comum o que eles denominavam de "incitação ao ódio de classes" (Weber, 1974, p.18).

${ }^{92}$ Neste período foram tomadas inúmeras medidas repressivas a fim de subordinar a Igreja ao Estado, desde prisões de clérigos até a censura à imprensa católica. O governo, apoiado pelos partidos liberais, tinha como objetivo obter o direito de sanção aos apontamentos da Igreja, controlar a educação e restringir a jurisdição das cortes eclesiásticas (Weber, 18974, p.9-11).
} 
Em 1878 os social-democratas foram responsabilizados por dois atentados contra a vida de Guilherme I, legitimando assim a elaboração de um projeto de lei anti-socialista. Este, no entanto, não conseguiu a aprovação do Reichstag, que foi então dissolvido. Após nova eleição, o governo obteve uma maioria para a aprovação da proposta. Por 221 votos contra 149, a lei foi acolhida, tendo entrado em vigor a partir de 19 de outubro de 1878.

A legislação anti-socialista aprovada pelo Reichstag proibia os socialistas de se organizarem em grupos, devendo toda reunião operária estar submetida à supervisão da polícia. A maioria de suas publicações foi tornada ilegal e seus distribuidores foram condenados judicialmente por difundirem um conteúdo "subversivo para a ordem pública e hostil ao interesse do Estado"93. Embora não restringisse a participação dos socialistas nas eleições (desde que desvinculados do partido político) e o direito de greve, a vedação ao direito de reunião e associação promoveu a desorganização do partido e de sindicatos.

Além de restringir as atividades do partido, proibir reuniões e periódicos e fechar associações socialistas locais, durante os doze anos em que vigorou o regime de exceção, 900 pessoas foram expulsas do país e 1500 condenadas a penas de prisão ${ }^{94}$.

A estratégia do governo, no entanto, não residia apenas em impor mecanismos de coerção. A repressão foi combinada com a tentativa de promover a cooptação das massas trabalhadoras. Com este fim foi criada uma máquina de propaganda do governo, financiada pelo "Fundo Guelph", que controlava a imprensa local ${ }^{95}$. Ademais, desde o início da década de 1880, Bismarck levou a cabo um programa de legislação social que incluía a criação de um sistema de seguridade social - com leis de seguro à saúde (1883), seguro por acidentes de trabalho (1884) e seguro por invalidez e velhice aos maiores de 60anos (1889) - e a regulação das condições de trabalho.

Por conseguinte, a concessão de benefícios sociais a partir de fundos públicos ou de fundos privados compulsórios foi utilizada como instrumento político para atrair os grupos reformistas ligados ao movimento operário. Weber chamara a atenção para a estratégia política do governo imperial que buscava conciliar paternalismo e política repressiva:

Ser convertida em demagogia (e péssima demagogia, diga-se) foi também o destino da legislação de beneficência social imperial nas mãos de Bismarck, por mais valiosa que se possa

\footnotetext{
${ }^{93}$ Nos seis primeiros meses em que vigorou a lei de exceção, 127 publicações periódicas e 287 não-periódicas foram censuradas. Nos dez anos seguintes estes números chegaram a 150 e 1.200, respectivamente (DROZ, Jacques. Histoire générale du socialisme - tomo II. Paris: Presses Universitaires de France, 1974, p.25).

94 JOLL, James. La Segunda Internacional. Movimiento obrero 1889-1914. Barcelona: Icalia, 1976, p.63.

${ }^{95}$ Weber, 1974, p. 76.
} 
considerar essa legislação em si mesma. Bismarck rejeitava a legislação trabalhista protetora, a qual, afinal de contas era indispensável à preservação dos recursos populacionais da nação. Rejeitava-a acusando-a, em parte com argumentos incrivelmente superficiais, de interferir nos direitos do patrão. Pela mesma razão, Bismarck utilizou-se das disposições da legislação anti-socialista para fazer a polícia destruir os sindicatos, os únicos possíveis portadores de uma representação realista de interesses da classe operária. Assim, compeliu os membros sindicais ao mais extremo radicalismo de pura política partidária ${ }^{96}$.

Até a morte de Guilherme I, em 1888, o governo não renunciou à política de "contensão socialista". No mês de abril de 1886, o Ministro do Interior, Robert von Puttkammer, elaborou um decreto proibindo as greves e tornando os social-democratas responsáveis de antemão por sua deflagração. Em julho do mesmo ano, o tribunal de Freiberg (na Saxônia) condenou a penas de prisão, sob o pretexto de reconstrução de ligas proibidas, nove líderes social-democratas, dentre eles Bebel e Vollmar ${ }^{97}$.

Ao assumir o império, Frederico III, cedeu às pressões das forças progressistas, demitindo von Puttkamer e adotando medidas mais liberais - como a anistia a presos políticos social-democratas -, prontamente rejeitadas por Bismarck. A sua morte, apenas três meses depois de assumir o poder, impediu a implementação de tais medidas, que seriam novamente aventadas no início do governo de Guilherme II.

Pressionado pelo progressivo avanço do movimento social-democrata, que em 1890 conseguiu obter $20 \%$ do total de votos, Guilherme II, que ascendeu ao trono em 1889, passou a adotar uma postura mais progressista, ensaiando uma maior aproximação com o movimento operário através da ampliação da legislação social. Assim, em 1890 anunciou seu apoio à greve dos mineiros no Ruhr ${ }^{98}$ e sua intenção de estender o seguro social e a regulação das condições de trabalho, fato que contribuiu para seu rompimento com Bismarck.

Ainda em 1890 Guilherme II inaugurou o "novo curso" de sua política através da instituição de uma lei responsável pela criação de Tribunais do Trabalho, órgãos destinados a mediar conflitos trabalhistas, que contariam com representantes de trabalhadores e empregadores. Em 1891 redigiu uma lei que determinava a abolição do trabalho aos domingos, limitava o trabalho infantil e feminino, proibia o pagamento em espécie, impunha regras ao trabalho insalubre, limitava o poder dos empregadores quanto à imposição de multas

\footnotetext{
${ }^{96}$ Weber, 1974, p.19.

${ }^{97}$ Somente de agosto a janeiro de 1889, 237 pessoas foram levadas ao tribunal (Droz, 1974, p.29).

98 A greve dos mineiros no Ruhr reuniu mais de 120.000 trabalhadores (Rodes, 1964, p. 407-449).
} 
aos empregados e sugeria o estabelecimento de conselhos de trabalhadores ou comitês de fábricas para ajudar a definir medidas de trabalho juntamente com os inspetores governamentais.

Além destas medidas, o Imperador defendeu a implementação de um programa de proteção ao trabalho a ser adotado por todos os países da Europa, por intermédio de uma "Conferência Internacional sobre Problemas do Trabalho", com o intuito de estabelecer medidas comuns em todos os países, e assim evitar uma competição desigual no âmbito do mercado. Por fim, Guilherme II rejeitou os apelos de Bismarck que bradava pela renovação das leis anti-socialistas com novas e mais duras penas. Como os partidos conservadores não aprovaram a versão mais branda das leis anti-socialistas, apresentadas pelo Imperador, estas leis não conseguiram ser aprovadas pelo Reichstag, tendo sido finalmente revogadas.

Durante os anos em que permaneceu na ilegalidade, ou seja, de 1878 a 1890, o Partido Socialista dos Trabalhadores Alemães assumiu a continuidade da luta socialista através de duas frentes: o trabalho na clandestinidade e a atuação dentro da lei, através da eleição de seus representantes para o Reichstag e, em alguns Estados, para o Landtag.

A estrutura do partido baseava-se fundamentalmente na ação dos "homens de confiança" (Vertrauensmänner), designados pelos membros do partido de cada localidade para que lhes representassem diante do organismo central ${ }^{99}$. Tentativas foram realizadas no sentido de organizar congressos secretos que contariam com os líderes do partido, os parlamentares social-democratas e os representantes municipais ou provinciais - como ocorreu, por exemplo, em Wyden (1880), Copenhague (1883) e St. Gall (1887) - mas não obtiveram sucesso em reunir grande número de pessoas.

Deste modo, enquanto suas atividades foram cerceadas pela legislação anti-socialista de Bismarck, os social-democratas dedicaram-se a prosseguir em seu trabalho de organização, administração e propaganda, empenhando-se na mobilização de novos militantes e na utilização do Parlamento como uma instância de discussão e palco para manifestação de sua total oposição ao governo.

Por força da lei de exceção foram criados ainda inúmeros clubes e associações esportivas e recreativas, com vistas a burlar a censura e a reagrupar o movimento. Eram celebradas reuniões fora do país e contrabandeados um grande volume de publicações socialistas - como o jornal "Der Sozialdemokrat”, impresso em Zurique e editado por Georg

\footnotetext{
${ }^{99}$ Neste sistema a direção encontrava-se altamente centralizada, cabendo aos homens de confiança repassarem as decisões do órgão central para os grupos locais.
} 
von Vollmar. O clima de repressão e a insatisfação em relação ao governo contribuíram para ampliar a base popular do partido ${ }^{100}$ e a radicalizar o movimento. No Congresso de Wyden (1880), foi retirado do programa do partido o termo "legais" da cláusula que dispunha que a ação da organização se daria "por todos os meios legais". Em Copenhague (1883), o partido declarou-se "revolucionário", sem ilusões quanto à realização dos seus objetivos pela via parlamentar.

Além de levar o partido a recorrer a meios ilegais para garantir sua sobrevivência, o acirramento da repressão fez aumentar a desconfiança do movimento operário em relação ao governo. Deste modo, várias correntes do partido que ainda sustentavam a política conciliatória de Lassalle passaram a abraçar a idéia da luta de classes. Por conseguinte, este período de aperfeiçoamento da luta clandestina deu ensejo à reestruturação do movimento, à revisão de seus princípios e ao reforço da identidade de classe. Relembrando o período de ilegalidade, Liebknecht escreveu:

A Alemanha é um despotismo com um falso constitucionalismo. Existe a ditadura do capitalismo representado pelo junkerismo, militarismo e polícia. Todas as organizações independentes dos trabalhadores foram proibidas - nós não tínhamos movimento operário antes do moderno movimento socialista, e a ausência de liberdade política nos forçou à luta política pela sobrevivência. ${ }^{101}$

O processo de radicalização do partido e o afloramento da crítica às instituições políticas do Reich propiciaram o redimensionamento da tática parlamentar, ora vista como instrumento inútil à causa proletária - como para o grupo de Johann Most e Wilhelm Hasselmann - ora concebida como um entre outros instrumentos para a organização, agitação e propaganda, capaz de demonstrar o fervor revolucionário das massas.

A expulsão dos grupos anarquistas no Congresso de Wyden, em 1880, fortaleceu o impulso em direção à reformulação da base teórica e prática da social-democracia sob a influência das idéias marxistas. Este processo de redefinição teórica contou com a intensa participação de Engels, que exerceu um papel fundamental na divulgação e atualização da teoria, sobretudo após a morte de Marx. A popularização de textos como o "Anti-Dühring” (1878) - ou de sua versão condensada, intitulada "Do socialismo utópico ao socialismo científico" - facilitaram a recepção e apropriação do marxismo pela social-democracia.

\footnotetext{
${ }^{100}$ Os incríveis êxitos eleitorais conquistados ainda durante o período de intensa repressão demonstraram a força de sua organização e a disciplina de seus membros. Confira a tabela 1, em anexo, com os números referentes ao resultado das eleições para o Reichstag.

${ }^{101}$ Entrevista de Liebknecht à revista “Justice” em 25/3/1899 (www.marxists.org).
} 
Assim, o final do século XIX foi marcado pela expansão e progressiva hegemonia do marxismo no interior do movimento operário europeu, destacando-se a influência exercida pela social-democracia alemã na difusão da teoria marxista e sua significativa conversão em paradigma organizativo para os demais partidos social-democratas criados. Deste modo, os partidos socialistas fundados entre 1884 e 1892 adotaram os princípios da ação política e da autonomia, concebendo a organização dos trabalhadores como o ponto de partida para a conquista do poder político pelo proletariado - uma classe social que tem como missão histórica libertar não só a si mesma, mas também a toda a humanidade. Tendo em vista a reorientação política do partido, o Congresso de Halle (1890) aprovou uma moção pela criação de um novo programa para o partido, que doravante passa a ser chamado de Partido Social-Democrata da Alemanha (Sozialdemokratische Partei Deutschlands).

O congresso seguinte, realizado em Erfurt (1891), portanto, introduziu mudanças não somente no tocante aos princípios adotados, mas também quanto à forma de organização. Se durante a ilegalidade era impossível reunir uma assembléia efetivamente representativa do partido, ou estabelecer um sistema de seções que pertencessem a um organismo central elegendo-se, então, homens de confiança para estarem em contato com os pequenos grupos de membros locais -, após a supressão da lei de exceção a estrutura básica do partido sofreu alterações. Assim, foi instituído um Congresso nacional de delegados eleitos em cada circunscrição eleitoral, dentro das mesmas condições que os homens de confiança; um Diretório partidário (Parteivorstand) composto de militantes eleitos pela Assembléia; uma Comissão de controle, igualmente nomeada pelo Congresso para examinar as contas do partido, composta por nove membros; e um jornal, o Vorwärts. Na base encontrava-se a união social-democrata de cada circunscrição, dividida eventualmente em grupos locais; e acima dela estavam as federações nacionais ou do Estado, cada uma com um Congresso e um Secretariado. ${ }^{102}$

Conforme a legislação se tornava progressivamente menos opressiva, ao longo das décadas seguintes - principalmente com a mudança na lei proibitiva de associações, em maio de 1908 -, o Partido Social-Democrata foi convertendo-se em uma organização como as demais, sendo permitida, inclusive, a admissão de mulheres. Contudo, a legalização do partido, em 1890, trouxe à luz novas e antigas questões, reanimando velhos conflitos e impondo novos desafios ao movimento social-democrata, como veremos a seguir.

${ }^{102}$ DROZ, Jacques. Histoire générale du socialisme - tomo II. Paris: Presses Universitaires de France, 1974, p.33. 


\section{2- Do Revisionismo Prático ao Revisionismo Teórico}

\section{1- A década de 1890 e o surto industrial}

O início da década de 1870 foi marcado pela incidência de uma grave crise econômica na Europa que vigorou até meados dos anos 90. Os inúmeros avanços nos setores de transportes marítimos e terrestres propiciaram o acirramento da competição entre produtos europeus e norte-americanos, conduzindo à queda dos preços dos alimentos e das matériasprimas e a uma prolongada recessão econômica.

$\mathrm{Na}$ Alemanha recém-unificada ${ }^{103}$, a concorrência com produtos agrícolas estrangeiros afetou as relações entre o campo e a cidade de modo significativo. A grande depressão causada pela queda dos preços agrícolas - particularmente de cereais, carnes e vegetais ${ }^{104}$ levou à ruína de pequenos camponeses do oeste e do sudoeste ${ }^{105}$ do Império. Nestas regiões havia o predomínio de pequenas propriedades em que os camponeses mantinham certo grau de independência. Estes camponeses cultivavam suas próprias terras ou as arrendavam para o cultivo de sua pequena lavoura. Devido ao seu tamanho e isolamento, ficavam extremamente vulneráveis diante do decréscimo dos preços agrícolas e freqüentemente eram levados a hipotecar ou vender suas terras.

Diferentemente, a noroeste (em Schleswig-Holstein) e ao sul (na Baixa Saxônia e na Baviera), onde predominavam os grandes e médios camponeses que não podiam cultivar suas terras sem parceiros, servos ou jornaleiros, foram criadas cooperativas e comunidades agrícolas que forneciam uma rede de apoio aos proprietários, evitando deste modo a sua falência. Já a leste do rio Elba, abrangendo grande parte do território da Prússia e de Mecklemburg, preponderava as grandes propriedades rurais e a agricultura em larga escala que fazia uso de criados, parceiros e trabalhadores assalariados (incluindo eslavos e poloneses). Dedicados ao cultivo intensivo de cereais (principalmente do trigo), beterrabas e batatas, destinados não apenas ao mercado interno, mas à exportação agrícola, os grandes proprietários rurais de origem nobre viram-se extremamente prejudicados com a crise no campo. Diante desta situação, muitos buscaram diversificar seus investimentos, recorrendo, por exemplo, à compra e locação de imóveis urbanos; já outros aproveitaram a queda nos

\footnotetext{
${ }^{103}$ Veja o mapa que destaca a incorporação de novos territórios na figura 1 dos anexos.

104 Para uma descrição detalhada dos efeitos da crise agrícola de 1873-1896, confira: STONE, Norman. La Europa transformada 1878-1919. Madrid: siglo veintiuno, 1985, p. 32-39.

105 Max Weber, em "Capitalismo e sociedade rural na Alemanha", apresenta as modificações internas da propriedade senhorial da terra, engendradas durante a Idade Média - século XIII a XV - que teriam originado a diferença entre as estruturas sociais rurais do leste e oeste (Weber, 1974, p.104-113).
} 
preços das terras para expandir seu domínio fundiário, tomando-as das mãos de pequenos e médios proprietários.

O declínio econômico dos grandes proprietários prussianos, no entanto, não determinou a perda de seu poder político e social. Desfrutando de uma posição privilegiada no governo, conseguiram assegurar tarifas alfandegárias, taxas de juros, subsídios e impostos que lhes eram favoráveis. Deste modo, garantiram a aprovação, em 1879, de uma série de medidas protecionistas que tinham em vista a elevação dos preços dos alimentos e das manufaturas, salvaguardando os interesses dos "senhores do aço e do centeio".

O auxílio governamental às elites agrárias, seja através da implementação de tarifas alfandegárias ou da concessão de transporte subsidiado, crédito barato e descontos em impostos, demonstra o prestígio e domínio reservados à nobreza, que permanecia exercendo um papel dirigente conservador e semi-autocrático. Arno Mayer, em "A Força da Tradição"106, ressaltou a primazia destas elites tradicionais que, além de conservarem sua supremacia na sociedade política, ainda retinham imensa riqueza e influência social e cultural. Segundo o autor, sua posição era "sólida e terrível" - e não precária e anacrônica precisamente porque seu imenso capital era não apenas cultural e simbólico, mas também econômico. Embora sua base material estivesse se debilitando devido ao relativo declínio do setor agrário, as nobrezas sustentariam suas fortunas econômicas graças à obtenção de apoio governamental, investimentos no setor não-agrário e a adoção de hábeis estratégias matrimoniais que os vinculavam à nascente burguesia industrial e financeira ${ }^{107}$.

Além de possuírem praticamente todos os latifúndios ${ }^{108}$, as nobrezas detinham o monopólio dos altos cargos do funcionarismo público civil ${ }^{109}$ e militar ${ }^{110}$. A maioria dos Ministros, Secretários de Estado e membros do corpo diplomático eram provenientes de famílias aristocráticas. Contudo, de acordo com Mayer, a nobreza carecia das habilitações

\footnotetext{
${ }^{106}$ MAYER, Arno J. A força da tradição. São Paulo: Companhia das Letras, 1987.

${ }^{107}$ Ibid, p. 131 .

${ }^{108}$ A nobreza deteria, em 1907, 13,5 milhões de acres. Havia 23.566 propriedades de mais de 250 acres cobrindo cerca de $23 \%$ da superfície cultivada da Alemanha, destas 19.117 estavam na Prússia. Já no oeste, sul e centro da Alemanha mais de $50 \%$ da terra cultivada era arrendada (25\% a pequenos camponeses no oeste, $18 \%$ no sul e $5 \%$ no centro). Apenas $20 \%$ das terras senhoriais eram arrendadas nas províncias orientais e menos de $10 \%$ a pequenos arrendatários (Mayer, 1987, p.35).

109 Segundo Mayer, em 1907, em todo o conjunto do império alemão, "25 dos 36 Regierungspräsidenten eram nobres, 6 dos 12 Oberpräsidialräte; 35 dos 131 Oberregierungsräte, 140 dos 69 étatsmässige Regierungsmitglieder (...), 217 dos 540 ausserestatsmässige Regierungsmitglieder, 121 dos 278 Regierungsassessorens e 271 dos 467 Landräte. Essa nobreza do serviço público incluía dois príncipes, 63 condes e 148 barões" (Mayer, 1987, p. 181).

${ }^{110}$ Mesmo tendo decaído a percentagem total de nobres no oficialato de $65 \%$ para $30 \%$ no período entre 1860 e 1913, conservavam certo monopólio das patentes militares mais elevadas (Mayer, 1987, p.177).
} 
necessárias para ocupar os escalões mais altos dos Ministérios da Guerra, Finanças, Agricultura e Justiça. Conseqüentemente, nestas áreas ter-se-ia verificado a ascensão política de elementos oriundos da alta burguesia.

A incorporação de grupos burgueses nos escalões inferiores do establishment cortesãoaristocrático e sua progressiva infiltração nos altos postos da administração civil e do oficialato militar não significaram, porém, uma ameaça ao status quo.A burguesia emergente não contestava nem o status social nem o poder da aristocracia. Neste sentido, agia menos como uma classe social "para si" - com um projeto político e cultural abrangente - do que um grupo de interesse e pressão em busca de objetivos econômicos.

Consoante o entendimento de Arno Mayer, a falta de coesão social e cultural entre os membros da burguesia industrial nacional e internacional, associada à sua desvantagem numérica e econômica, inviabilizava quaisquer pretensões de oferecerem resistência ao poder das elites tradicionais. Logo, às burguesias emergentes - enfraquecidas pelas divisões internas entre a indústria pesada e a manufatura de bens de consumo em grande escala (e seus respectivos associados bancários) e, ao mesmo tempo, separadas da pequena manufatura e do comércio (o que as desprovia de uma ampla base popular) - foi reservado um papel político secundário como aliadas das classes governantes.

Em troca do apoio ao governo e da submissão ao poder da elite agrária, as burguesias conseguiam o atendimento de várias reivindicações de cunho econômico, além de manter sob controle as camadas proletárias em plena expansão. Como observou Engels, em seu prefácio de 1891 à "Guerra Camponesa na Alemanha",

por um lado o governo, a passos de tartaruga, reforma as leis no interesse da burguesia, elimina os entraves feudais e os obstáculos criados pelo particularismo dos pequenos Estados, que impedem o desenvolvimento da indústria; introduz a unidade das moedas, dos pesos e medidas, estabelece a liberdade de indústria, etc; implanta a liberdade de domicílio, pondo assim à disposição do capital e em forma ilimitada a mão-de-obra da Alemanha; fomenta o comércio e a especulação; por outro lado, a burguesia cede ao governo todo o poder político efetivo, aprova os impostos, os empréstimos e o recrutamento de soldados e ajuda a formular todas as novas leis de reforma, de modo que o velho poder policial sobre os elementos indesejáveis conserve toda a sua força. A burguesia adquire sua paulatina emancipação social ao preço de sua renúncia imediata a um poder político próprio ${ }^{111}$.

${ }^{111}$ Marx, Engels, 1980b, p.199. 
A subordinação política e cultural da burguesia industrial e financeira à aristocracia manifestava-se também na assunção de uma mentalidade autoritária e militarizada e na adoção dos valores pertencentes ao código de comportamento monárquico-aristocrático. A fim de assegurar seus interesses e adquirir prestígio e legitimidade social, a alta burguesia do Império passou, portanto, por um processo de "aristocratização" ou "enobrecimento". Além do ingresso no serviço público civil e militar, da obtenção de títulos ${ }^{112}$ e ordens honoríficas ${ }^{113}$ e da aristocratização de nomes de família ${ }^{114}$, seus membros reproduziam o código social e o estilo de vida da aristocracia ${ }^{115}$. Deste modo, conforme atenta Mayer,

a velha nobreza rural e os novos magnatas do capital na realidade nunca entraram numa rota de colisão. No máximo acotovelavam-se ao manobrarem em busca de posições entre as classes dirigentes, onde a burguesia permanecia como seguidora e pretendente feudal. Nobres inveterados ocupavam e controlavam rigidamente $\mathrm{o}$ acesso ao alto patamar social, cultural e político a que aspirava a burguesia. Com uma flexibilidade e capacidade de adaptação características, e capitalizando a avidez do elemento burguês por status e avanço social, os grandes notáveis admitiam em seu meio postulantes individuais oriundos do mundo dos negócios e profissões. Em vez de ceder terreno institucional, optavam por essa cooptação seletiva [grifo nosso], seguros de sua habilidade para conter e neutralizar sua simultânea contaminação ideológica e cultural. $^{116}$

A assimilação do ritual, da mística e dos valores cortesão-aristocráticos encontrava lugar nas escolas e instituições culturais da elite. Nos Gymnasien era propagado o ensino

\footnotetext{
112 Entre 1871-1918, foram elevados 1.129 homens à nobreza. Guilherme I, por exemplo, enobreceu os banqueiros Schicker, Friedrich Wilhelm Krause, Adolf Hansemann e Gerson Bleichroeder; Frederico III enobreceu o banqueiro Ernst Mendelssohn e o industrial Karl Ferdinand Stumm; Guilherme II concedeu 836 títulos entre 1890 e 1918, entre proprietários rurais, generais e altos funcionários públicos, sendo que os títulos superiores eram reservados para os descendentes da nobreza agrária e dos serviços públicos (Mayer, 1987, p.102).

${ }^{113}$ Como estratégia de cooptação social eram conferidas condecorações como a Águia Vermelha, a Águia Negra e a Cruz de Cavaleiro da Casa de Hohenzollern. Além disto eram distribuídos títulos oficiosos, como de Kommerzienrat, Justizrat, Baurat, Medizinalrat e Regierungsrat (Mayer, 1987, p.104-105).

114 "Fabricantes e comerciantes que enriquecessem comprariam as propriedades dos cavaleiros, associando sua posse à família pelo usufruto e usando a propriedade como meio de invadir a classe aristocrática". Cf. Cf. WEBER, Max. "Capitalismo e sociedade rural na Alemanha". In: Ensaios de Sociologia..Coleção Os pensadores. São Paulo: Abril Cultural, 1974, p.111. Escrito de 1906.

115 Segundo Arno Mayer, "em particular durante o meio século anterior a 1914, os "burgueses enriquecidos" sistematicamente insistiram em sua procura de títulos que legitimassem "sua ligação com a classe dominante e adaptaram as novas forças sociais ao antigo ambiente aristocrático", assim também "revigorando" a nobreza, de início hostil, com "sangue novo e nova energia econômica" " (Mayer, 1987, p. 104).

${ }^{116}$ Mayer, 1987, p.89.
} 
secundário clássico, centrado na Bildung ${ }^{117}$, destinado a uma elite social seleta que, assim, garantia sua via de ingresso na universidade ${ }^{118}$. Desta maneira, embora o ensino superior fosse público - posto que os Kulturministerien dos Estados financiavam e administravam as escolas secundárias e universidades - apenas uma pequena fração da população tinha acesso ao ensino tradicional e aos privilégios oficiais dele decorrentes ${ }^{119}$, como a possibilidade de ingresso em carreiras no serviço público civil $^{120}$, na Igreja, em profissões liberais e na academia $^{121}$.

Concomitantemente verificava-se a expansão do funcionarismo burocrático civil ${ }^{122} \mathrm{e}$ militar, dando origem a uma nova classe média que se infiltrava no corpo das grandes empresas e sociedades por ações, nas organizações públicas e privadas, na imprensa, no sistema educativo e na administração estatal e local. Como Weber observou, estas novas categorias de funcionários e técnicos eram caracterizadas pelo formalismo na realização de suas atribuições e pela impessoalidade de seus vínculos empregatícios - com salário, pensão, critérios de promoção, treinamento especializado, divisão funcional do trabalho, áreas bem definidas de jurisdição, processos documentados e ordenação hierárquica ${ }^{123}$. Por conseguinte, a educação superior converteu-se em um fator importante na estratificação social, uma vez que através dela as classes médias abastadas puderam constituir uma elite culta de

\footnotetext{
${ }^{117}$ Concepção de educação que envolve a formação da personalidade, a aquisição de valores da Kultur. O ensino era considerado "puro", ou seja, sem finalidades práticas ou aplicabilidade imediata. Cf. ELIAS, Norbert. $O$ processo civilizador. v.1. Rio de Janeiro: Jorge Zahar, 1994, p. 23-43.

${ }^{118}$ O Gymnasium era a única via para a universidade, posto que, ao final possibilitava a realização de um exame final (Abitur) que determinaria o ingresso do estudante, diferentemente das Realschulen, dos Realgymnasien e das technische Hochschule (institutos técnicos e profissionalizantes) (Mayer, 1987, p.259-260).

${ }^{119}$ Como Weber observou, o jurista e o funcionário administrativo na Alemanha, apesar de sua educação mais rápida e intensiva, no preparo para a universidade, tem cerca de trinta e cinco anos quando seu período de preparo e sua atividade não-remunerada é concluída e ele consegue um cargo lucrativo. Portanto, só pode sair dos círculos abastados; é preparado para um serviço não-remunerado, ou mal remunerado, e só pode encontrar recompensa pelo seu trabalho na alta posição social de sua vocação. Cf. WEBER, Max. "Capitalismo e sociedade rural na Alemanha”. In: Ensaios de Sociologia. Coleção Os pensadores. São Paulo: Abril Cultural, 1974. Escrito de 1906.

${ }^{120}$ Desde 1791 a Prússia introduziu exames regulares de qualificação para o serviço público que exigiam o diploma universitário. Cf. RINGER, Fritz K. O declínio dos mandarins alemães: a comunidade acadêmica alemã, 1890-1933. São Paulo: Edusp, 2000, p.31.

${ }^{121}$ Convém ressaltar, no entanto, que a camada aristocrática ainda assumia posição social e política de destaque também no âmbito acadêmico e profissional. Assim, o acesso a títulos acadêmicos e a altos cargos nas universidades era restrito a uma elite tradicional. Cf. RINGER, Fritz K. O declínio dos mandarins alemães: a comunidade acadêmica alemã, 1890-1933. São Paulo: Edusp, 2000

${ }_{122} \mathrm{Na}$ Alemanha, em 1881 havia 452.000 funcionários públicos civis, em 1901 havia 907.000 e em 1911 1.159.000 (Rodes, 1964, p.145).

${ }^{123}$ Weber, 1974, p.117.
} 
funcionários públicos, acadêmicos e profissionais liberais que passaram a integrar inclusive o aparelho do Estado ${ }^{124}$.

Deste modo, conforme exposto por Fritz Ringer, graças à vinculação entre as universidades e a burocracia estatal, "acabou surgindo, paralelamente à estratificação tradicional pelo nascimento, uma nova divisão da sociedade com base na profissão e no grau de instrução" 125 , permitindo à classe média alta não-empresarial - a "aristocracia mandarim da cultura" - tornar-se parte da classe governante funcional do país ${ }^{126}$. Esta elite intelectual formaria uma "aristocracia da educação", apegada a valores éticos, estéticos e políticos tradicionais. Isto era evidenciado desde o momento de ingresso dos estudantes nas universidades, quando estes procuravam aderir a confrarias (Landsmannschaften) ${ }^{127}$ orientadas por um ethos guerreiro, centrado em valores tradicionais de honra, disciplina, lealdade, obediência e coragem. Tais agremiações estudantis possuíam uma estrutura hierárquica e autoritária, exigindo de seus integrantes o apego ao código de conduta aristocrático, expresso especialmente através da prática do duelo. Desta maneira, os estudantes das classes médias abastadas poderiam se infiltrar em organizações tradicionais, com vistas a superar estigmas e adquirir maior status na sociedade.

O cultivo dos valores tradicionais nas universidades alemãs e sua vinculação com o Estado abriram caminho para que estas constituíssem locais privilegiados para o florescimento do pensamento conservador. A visão predominante entre os "mandarins" alemães, isto é, a elite culta da academia, apresentava fortes elementos religiosos, aristocráticos, autoritários e nacionalistas ${ }^{128}$. A “ortodoxia mandarim” demonstrava profundo receio em relação à democracia representativa e à sociedade industrial, e, em contrapartida, exaltava freqüentemente os valores herdados da antiga ordem feudal. Assim, criticavam a expansão do domínio do capital, do egoísmo e do pragmatismo, e defendiam o rejuvenescimento ético da vida política. Segundo Weber, tal tipo de conservadorismo possuía

\footnotetext{
${ }^{124}$ De acordo com Norbert Elias, antes da Primeira Guerra Mundial 90\% dos estudantes em universidades alemães provinham das classes médias abastadas. Cf. ELIAS, Norbert. Os alemães: a luta pelo poder e a evolução do habitus nos séculos XIX e XX. Rio de Janeiro: Jorge Zahar, 1997, p.48.

${ }^{125}$ Ringer, 2000, p.31.

${ }^{126}$ Ibid, p.51.

127 Confrarias como a "Borussen" de Bonn, a "Westphalen" de Heidelberg e a "Canitzer" de Leipzig (Mayer, 1987, p.259).

${ }^{128}$ Cf. RINGER, Fritz K. O declínio dos mandarins alemães: a comunidade acadêmica alemã, 1890-1933. São Paulo: Edusp, 2000.
} 
a pretensão de "proteger o espírito alemão da contaminação pela democracia"129, defendendo uma política de contenção das classes trabalhadoras.

Estes representantes intelectuais dos junkers e da alta burguesia industrial e financeira pregavam igualmente em favor do protecionismo econômico e da expansão territorial. Conseqüentemente, em 1891, um considerável número de professores universitários, generais, jornalistas, políticos e industriais reuniram-se em torno da Liga Pangermanista (Alldeutscher Verband), no intuito de fornecer apoio à política expansionista promovida pelo governo.

Não obstante o peso exercido pelo conservadorismo sobre o ensino superior, convém ressaltar que a elite culta também possuía seus elementos progressistas ou, seguindo a denominação Ringer, "modernistas". Estes intelectuais não expressavam grande simpatia pelos objetivos específicos de classe nem da burguesia empresarial emergente nem das classes tradicionais agrárias e aristocráticas. Tampouco cediam às reivindicações radicais de artesãos e operários social-democratas, encaradas como inconsequientes e caóticas. De acordo com Ringer, o interesse destes intelectuais por questões de ordem econômica e social limitava-se a um anseio muito vago de harmonia social e a exigência da intervenção governamental com vistas à implementação de reformas moderadas ${ }^{130}$. Destarte, tanto conservadores como modernistas expressavam uma forte ligação com o Estado e as classes governantes e certa apreensão em relação à nova sociedade industrial e seus conflitos internos.

Como foi visto, ao permearem o Estado e os grupos dirigentes, as burguesias emergentes assumiram em larga medida a mentalidade aristocrática e conservadora das nobrezas do Império. Com efeito, como nos explica Norbert Elias, em “Os Alemães”, "vastos setores da alta burguesia, com os escalões superiores do funcionarismo civil e os bacharéis na liderança, submeteram-se prazerosamente e, muitas vezes, com entusiasmo à liderança política e militar da corte e da nobreza"131. Desta forma, a sociedade em vias de modernização manteve uma estrutura social aristocrática mediante a "simbiose ativa" - nas palavras de Schumpeter - entre os dois estratos sociais ${ }^{132}$. Logo, privilégios sociais, status, prestígio e o caráter autoritário que compunham a marca política da aristocracia passaram a integrar as pretensões da burguesia, dando origem à figura do "plebeu de verniz" ${ }^{133}$. Em outras palavras,

\footnotetext{
${ }^{129}$ Weber, 1974, p.33.

${ }^{130}$ Ringer, 2000, p.127.

${ }^{131}$ ELIAS, Norbert. Os alemães: a luta pelo poder e a evolução do habitus nos séculos XIX e XX. Rio de Janeiro: Jorge Zahar, 1997, p.66.

132 MAYER, Arno J. A força da tradição. São Paulo: Companhia das Letras, 1987, p.40.

${ }^{133}$ Weber, 1974, p.117.
} 
Enquanto a elite agrária sólida e tradicional era excessivamente absorvente e elástica, a burguesia era singularmente impressionável e flácida. Os magnatas do capital e das altas profissões liberais nunca se aglutinaram o suficiente para contestar seriamente o predomínio social, cultural e ideológico da antiga classe dominante, e o fato de a nobreza continuar a cooptar alguns dos mais ricos e talentosos dentre eles contribuiu apenas em parte para isso. Acima de tudo o burguês, devido a seu caráter bajulatório, empenho na escalada social e anseio de enobrecimento, negava-se avidamente a si próprio [grifo nosso]. Sua suprema ambição não era atacar ou derrubar o establishment senhorial, mas penetrar nele [grifo nosso]. Para os grandes negociantes, financistas e profissionais liberais, social e psicologicamente inseguros, a alta burguesia "era apenas uma antecâmara para a nobreza", e sua "mais alta aspiração era, em primeiro lugar, conseguir a admissão à nobreza e, depois, ascender no seu interior ${ }^{134}$.

Conforme aduz Arno Mayer, “essa maciça, reverente e venal adaptação social e cultural da burguesia ajudou a abrir canais de acesso à sociedade política, onde o elemento feudal continuava a dominar" ${ }^{135}$. Sendo assim, os magnatas do capital barganhavam seus direitos e reivindicações políticas por vantagens econômicas, status social e privilégio civil. Defrontada com o espantoso crescimento dos partidos social-democratas, a burguesia abdicou de disputas com a classe dirigente para engajar-se em uma frente conservadora e autoritária que garantia suporte ao governo imperial semi-autocrático. Ao invés de exercer pressão por uma democratização política, a burguesia alemã agrupou-se em torno de partidos "moldados à sua própria imagem subserviente", que se restringiam basicamente à defesa e promoção de seus interesses econômicos.

Como nos mostra Engels, o equilíbrio entre a nobreza latifundiária e a burguesia abriu caminho para o estabelecimento de uma "monarquia bonapartista moderna", na qual os junkers controlavam a política tanto através da Câmara dos Lordes prussiana e no Landtag (onde havia o sistema eleitoral por classes), quanto através do Reichstag, no qual saíam fortalecidos devido à defasagem do censo eleitoral que acabava por favorecer os distritos agrários:

O verdadeiro poder governamental encontra-se em mãos de uma casta especial de oficiais e funcionários recrutada, na Prússia, em parte no seio de suas próprias fileiras, em parte entre a pequena nobreza, e em menor medida ainda entre a burguesia. A independência desta casta, que parece manter-se

\footnotetext{
${ }^{134}$ Mayer, 1987, 91, 92.

${ }^{135}$ Ibid, p. 104.
} 
fora e, por assim dizer, acima da sociedade, confere ao Estado uma aparência de independência em relação à sociedade ${ }^{136}$.

A limitação das reformas burguesas à implantação, em 1866, do sistema único de pesos e medidas, da liberdade de domicílio e de liberdade de indústria e comércio, possibilitou então o avanço do desenvolvimento industrial sem, contudo, alterar as estruturas sociais, culturais e políticas tradicionais. Por conseguinte, até 1914, "o capitalismo industrial e financeiro, para não falar do capitalismo gerencial, continuou a ter importância secundária, não só em termos econômicos, inclusive quanto à economia internacional, mas ainda em termos de classe, status e poder"137.

Consoante expõe Norbert Elias, "ao contrário do que sugere o uso um tanto impreciso da expressão "sociedade capitalista", no período após 1871, os capitalistas financeiramente poderosos não formavam ainda, em absoluto, o estrato socialmente mais poderoso e, concomitantemente, o mais elevado da sociedade alemã ${ }^{, 138}$. Corroborando tal concepção, Mayer destacou que a crise econômica que se estendeu dos meados dos anos 1870 a meados dos anos 1890, não chegou a ser um divisor de águas entre o velho e o novo capitalismo e tampouco inaugurou uma era de "conflitos aguçados entre o crescimento da capacidade produtiva e a rentabilidade do negócio". Para o autor, embora o novo capitalismo se estabelecesse sob a forma de centros de crescimento semi-autônomos dentro das estruturas econômicas existentes, não estava em posição de assumir o comando sobre a economia política da Europa ${ }^{139}$.

Mesmo o rápido e substancial desenvolvimento industrial levado a efeito a partir de meados do século XIX, impulsionado pelo progresso nas técnicas de produção, não teria conseguido tornar o novo capitalismo capaz de suplantar a agricultura e a manufatura de bens de consumo, que continuavam a superar o setor de bens de capital ${ }^{140}$. Apesar dos avanços do novo capitalismo, a agricultura, a propriedade imobiliária urbana e a manufatura de bens de consumo continuavam a empregar grande parte da força de trabalho da Alemanha e a gerar

\footnotetext{
${ }^{136}$ MARX, K, ENGELS, F. "Contribuição ao problema da habitação”. In Obras escolhidas. São Paulo: AlfaOmega, v.2, 1980b, p.157.

${ }^{137}$ Mayer, 1987, p.53.

${ }^{138}$ Elias, 1997, p.54.

${ }^{139}$ Mayer, 1987, p.28.

${ }^{140}$ A Alemanha permanecia, portanto, predominantemente rural e agrária, e não urbana e industrial. Em 1907 $40 \%$ da população ainda morava em aldeias e vilas com menos de 10 mil habitantes, $40 \%$ da força de trabalho dedicava-se à terra, para produzir 20\% da renda nacional (Mayer, 1987, p.33).
} 
uma maior porção do produto nacional bruto ${ }^{141}$. Assim, como Mayer apontou, "o setor de bens de capital era como um arquipélago rodeado por vastos oceanos de agricultura e manufatura tradicional" 142 .

Durante todo século XIX e início do século XX os proprietários de pequenas oficinas constituíram a espinha dorsal da classe média baixa independente ${ }^{143}$. Enquanto a economia permanecia dominada pelo capitalismo mercantil e manufatureiro - principalmente de bens de consumo como produtos têxteis, gêneros alimentícios, couro e madeira -, o capitalismo monopolista financeiro ou industrial estaria ainda entrando em sua fase inicial de crescimento:

Centrado nas e em torno das cidades mais antigas, o mundo das oficinas e artesãos obscurecia as fábricas e a mão-de-obra proletária dos centros urbanos e zonas industriais mais recentes em termos de força de trabalho, capitalização e valor da produção. Paradoxalmente, o crescimento da produção fabril e das cidades beneficiou as oficinas e os trabalhadores artesanais, ao estimular a demanda de bens e serviços que apenas eles poderiam fornecer, em particular quanto à moradia, alimentação, vestuário e instrumentos de precisão. Em outras palavras, enquanto alguns ramos da manufatura tradicional indubitavelmente se contraíam ou estagnavam, outros floresciam e se expandiam. ${ }^{144}$

Portanto, as empresas com produção em grande escala, capital intensivo, financiamento externo a longo prazo e força de trabalho proletária constituíam a exceção diante do vasto setor manufatureiro de pequenos trabalhadores e capitalistas familiares com mão-de-obra de artífices e artesãos que trabalhavam em pequenos galpões ou oficinas com até 5 trabalhadores. A proliferação da indústria doméstica, realizada em condições precárias e insalubres, ocorreu principalmente na Alemanha central - onde todas as formas de produção e de propriedade apareciam mescladas em proporções diferentes segundo a localidade ${ }^{145}$.

\footnotetext{
141 “A grande propriedade fundiária constituía a principal fonte não só das extravagantes rendas e riquezas das elites agrárias, como também de desmedido prestígio social, predomínio cultural e influência política. Em todos os aspectos, incluindo número e riqueza, os senhores rurais continuavam a superar os magnatas dos negócios e das profissões liberais" (Mayer, 1987, p.34).

${ }_{142}$ Mayer, 1987, p.30.

${ }^{143}$ Em 1907, 90\% de todas as firmas no setor conjunto da manufatura e indústria ainda empregavam até cinco trabalhadores, embora a força de trabalho nas pequenas empresas tivesse reduzido em 1/3 desde 1875, representava $31,2 \%$ de toda a força de trabalho manufatureira e industrial (Mayer, 1987, p.47). ${ }^{144}$ Mayer, 1987, p.44.

${ }^{145}$ MARX, K, ENGELS, F. “O Problema camponês na França e na Alemanha”. In Obras escolhidas. São Paulo: Alfa-Omega, v.2, 1980b, p. 226-227.
} 
Esta industria de domicílio rural ${ }^{146}$, praticada em aliança com a horticultura ou o pequeno cultivo ${ }^{147}$, comporia, para Engels, a base para a "jovem grande indústria alemã",148. De acordo com o autor, os produtos - como fumo e tecidos - derivados do trabalho a domicílio rural e da utilização de mão-de-obra familiar, seriam vendidos no mercado a preços muito baixos, devido à concorrência com a produção mecanizada ${ }^{149}$, afetando o nível geral dos salários, tanto no campo como nas cidades.

Embora os artesãos continuassem a ser o elemento dominante na classe trabalhadora, vinham sofrendo com as pressões e desgastes da modernização capitalista. Como nos mostra Mayer, ao serem defrontados com importantes mudanças nos métodos de produção e distribuição, os artesãos tinham de lutar arduamente para manter sua autonomia, qualificação, status e padrão de vida ${ }^{150}$, posto que, ao contrário dos trabalhadores nas indústrias de bens de capital, extração mineral e ferrovias, que se organizavam por ramos industriais, eles continuavam divididos por ofícios artesanais. Deste modo, "ciosos de sua independência pessoal e profissional, os artesãos tinham dificuldade em desenvolver instrumentos e estratégias de autodefesa que ocupassem o lugar das guildas e salvaguardas legais que presumivelmente lhes havia servido tão bem em outros tempos difíceis"151.

Não obstante a permanência e adaptação das pequenas e médias manufaturas, a década de 1890 testemunhou um grande surto industrial que engendrou transformações econômicas, políticas e sociais em um ritmo e intensidade sem precedentes na história alemã. Por conseguinte, após um longo período de depressão econômica e ciclos de recessão, que abarcou as décadas de 1870 e 1880, tem início na Alemanha uma fase de grande prosperidade e expansão capitalista ${ }^{152}$.

\footnotetext{
${ }^{146}$ Tipo de produção encontrada no Baixo Reno, Westfalia, Erzgebirge da Saxônia, Silésia e nos bosques da Tuníngia e no Rhön.

${ }^{147}$ Como a terra própria ou arrendada não supria o sustento da família, passou a servir apenas de base para a exploração de uma indústria doméstica.

${ }_{148}$ MARX, K, ENGELS, F. "Contribuição ao problema da habitação". In Obras escolhidas. São Paulo: AlfaOmega, v.2, 1980b, p. 110. Escrito por Engels em 1873.

${ }^{149}$ A tecnologia utilizada na manufatura de bens de consumo era a da primeira Revolução Industrial, em particular quanto ao emprego de carvão e vapor, além da pronta disponibilidade de ferro, aço e transporte ferroviário. Esse amplo setor compreendia, sobretudo, empresas de uma só unidade, com pequenas oficinas, trabalho intensivo e instalações de médio porte (abaixo do nível das fábricas), com equipes de artesãos e trabalhadores não-qualificados operando com maquinaria simples e de baixo consumo de energia. Devido à sua capitalização relativamente pequena, a maioria das empresas manufatureiras era de propriedade familiar, financiada e dirigida pela própria família (Mayer, 1987, p.29).

${ }^{150}$ Mayer, 1987, p.45.

${ }^{151}$ Ibid.

${ }^{152}$ Para uma caracterização minuciosa do período veja as obras de G.D.H. Cole (1859), Jacques Droz (1974), Peter Gay (1970), Eric Hobsbawm (2005), Carl Schorske (1972) e John Rodes (1964).
} 
Esta "revolução industrial" 153 , experimentada tardiamente pela Alemanha, foi produto direto de uma política econômica de forte incentivo à industrialização e ao comércio - levada a efeito por Bismarck desde os primórdios do Império - aliada ao financiamento proveniente de bancos e empresas privadas. A origem deste processo de expansão capitalista e industrialização, que remete ao período anterior à unificação política do Império, foi descrita por Engels no segundo prefácio à "Contribuição ao problema da habitação", de 1887:

A Alemanha surgia tardiamente no mercado mundial. Nossa grande indústria teve início na década de 40 e recebeu o seu primeiro impulso na Revolução de 1848; não pôde desenvolverse plenamente senão quando as revoluções de 1866 e 1870 varreram de seu caminho pelo menos os piores obstáculos políticos ${ }^{154}$.

O governo desempenhou papel ativo no processo de desenvolvimento econômico através da implementação de um sistema de crédito e subsídios direcionado às indústrias pesadas $^{155}$, químicas ${ }^{156}$ e elétricas ${ }^{157}$, do investimento em institutos independentes e em universidades que desenvolviam pesquisas aplicadas aos setores industriais (como a de Berlim, Heidelberg, Bonn, Göttingen e Giessen), da ampliação da rede ferroviária ${ }^{158}$ e da construção de um sistema de transporte marítimo ${ }^{159}$. Estas medidas produziram rápidos e

\footnotetext{
${ }^{153}$ Esta arrancada da segunda Revolução Industrial na Alemanha, foi impulsionada pelos avanços nas técnicas e setores envolvendo a química orgânica e sintética, a energia elétrica, a construção de turbinas e máquinas de combustão interna e a utilização e manejo de metais não-ferrosos e ligas especiais, incluindo novos processos de beneficiamento de minério de ferro. Estas inovações técnicas, combinadas a novas fontes de energia e materiais, proporcionou o crescimento de empresas e o desenvolvimento de setores de ponta da indústria de bens de produção.

${ }^{154}$ Marx, Engels, 180b, p.113.

155 Cabe ressaltar que a produção alemã de aço e ferro conseguiu ultrapassar a produção inglesa já em 1900 e chegou a dobrá-la em 1910 (Rodes, 1964, p.381). Segundo Ramanosk (2005, p.42), a produção de aço passou de 1,2 milhão de toneladas em 1887, para 18,9 milhões de toneladas em 1913. Já a produção de ferro gusa subiu de 1,5 milhão de toneladas em 1870 para 14,8 milhões em 1910. Empresas especializadas em siderurgia como a Krupp, Thyssen, Stumm-Halberg e Donnersmark, tiveram estrondoso crescimento no período (Ramanosk, 2005, p.42).

${ }^{156} \mathrm{O}$ progresso das indústrias químicas impulsionou o desenvolvimento de outros ramos estratégicos, como a agricultura, a indústria bélica e a indústria farmacêutica. Grandes empresas alemãs como a Bayer (Farben Fabriek Vormals Friedrich Bayer), Hoechst e BASF (Badische Anilin und Soda Fabriek) - localizadas na Renânia-Westfália - eram responsáveis pela fabricação de corantes e derivados (ácido sulfúrico, carbonato de sódio, amônia, cloro, hidrogênio, fósforo, etc) utilizados para a confecção de inúmeros produtos, como fertilizantes, papel, explosivos e medicamentos (Ramanosk, 2005).

157 Empresas como o complexo Siemens-Schuckert e a Allgemeine Elektrizitäts Gesellschaft (A.E.G), destacaram-se na indústria elétrica (Ramanosk, 2005).

${ }^{158}$ As ferrovias, que em 1870 alcançavam cerca de $19.500 \mathrm{~km}$, atingiram $61.000 \mathrm{~km}$ em 1910 (Ramanosk, 2005, p.42).

${ }^{159}$ A política de apoio à construção naval tinha como principais objetivos ampliar o volume de exportações e tornar possível a expansão colonial alemã na África, Nova Guiné e no Pacífico (Rodes, 1964; Hobsbawm, 2005).
} 
eficientes resultados, transformando a Alemanha, em apenas algumas décadas, em um dos países mais industrializados do mundo ${ }^{160}$.

Tal política se fez possível, entre outras razões, graças ao montante de cinco bilhões de francos pagos como indenização pelo governo francês, após a derrota de 1870. Como salienta Engels, no referido prefácio,

choviam sobre a Alemanha os bilhões franceses; o Estado pagou suas dívidas; construíram-se fortificações e quartéis e foram renovados os estoques de armas e munições; o capital disponível, assim como a massa de dinheiro em circulação, aumentaram de repente em enorme escala. E tudo isso exatamente no momento em que a Alemanha surgia na cena mundial não só como "Império unido", mas também como um grande país industrial. Os bilhões deram um formidável impulso à jovem grande indústria; foram eles, sobretudo, que trouxeram depois da guerra um curto período de prosperidade, rico em ilusões e, imediatamente em seguida à grande bancarrota de 1873/1874, que demonstrou que a Alemanha era um país industrial já maduro para participar no mercado mundial ${ }^{161}$.

Como resultado, somente entre os anos de 1893 e 1902 a produção industrial teve crescimento de $45 \%{ }^{162}$. Todavia, o processo de industrialização induziu à predominância de grandes empresas ${ }^{163}$. De acordo com Arno Mayer, como as grandes fábricas de capital intensivo - que aumentavam a eficiência marginal da mão-de-obra - exigiam uma escala de investimentos que ultrapassava as capacidades financeiras do empreendimento familiar, mesmo empresas de controle familiar converteram-se em postos avançados do capitalismo gerencial de corporações, originando uma burguesia de negócios dotada de uma perspectiva nacional e de laços crescentes com o governo e os bancos de investimento ${ }^{164}$.

\footnotetext{
${ }^{160}$ Cabe lembrar que a unificação alemã tornou possível a exploração de novas fontes de riqueza, permitindo o acesso a regiões ricas em recursos naturais, como na Alsácia e Lorena (minas de potássio), Sarre (carvão), Ruhr (carvão), Silésia (carvão), Renânia (linhito), Elbe e Weser (depósitos de sal). Assim, a produção de carvão e linhito passou de 37,9 milhões de toneladas em 1871 para 279 milhões em 1913 (Ramanosk, 2005, p.42). As maiores corporações da indústria pesada da Alemanha combinavam a mineração do carvão e do ferro com a siderurgia e a construção de máquinas, por exemplo a Krupp, Thyssen e Gutehoffnungshütte, no Ruhr; Röchling e Stumm, no Saar, e Henckel-Donnersmarck, na Alta Silésia e no Reno (Mayer, 1987, p.58).

${ }^{161}$ Marx, Engels, 1980b, p.107.

162 GUSTAFSSON, Bo. Marxismo y revisionismo: La critica bernsteiniana del marxismo y sus premisas histórico-ideológicas. México: Grijaldo, 1975, p.23.

${ }^{163}$ Entre 1882 e 1907 o número de companhias com mais de 50 trabalhadores (incluindo da construção civil e extração de minério) aumentou de 9500 para 27 mil, e sua força de trabalho passou de 1,6 milhão para 5 milhões. Ainda assim, firmas com 1 a 5 e 6 a 50 trabalhadores ainda respondiam, respectivamente por $90 \%$ e $8,7 \%$ das unidades de produção, e empregavam $29,1 \%$ e $23,2 \%$ dos trabalhadores manufatureiros e industriais. Deste modo, as grandes firmas perfaziam apenas $1,3 \%$ de todas as unidades de produção empregavam $47,7 \%$ dos trabalhadores manufatureiros e industriais (Mayer, 1987, p.58).

${ }^{164}$ Mayer, 1987, p.30.
} 
A concentração industrial levou à criação de poderosos cartéis ${ }^{165}$ em setores como o do aço, do carvão e das indústrias químicas, freqüentemente controlados por grandes bancos especializados em crédito - como o Reichsbank, Diskonto, Dresdner, Darmstädter, ou Deutsche, por exemplo - , que na prática agiam como holdings ${ }^{166}$. Logo, o número de grandes empresas entre os anos de 1882 e 1907 aumentou em 221\%, enquanto que, no mesmo período, as médias empresas aumentaram em $137 \%$ e as pequenas sofreram um aumento de apenas $8 \%{ }^{167}$.

Do mesmo modo, o número de trabalhadores empregados em grandes empresas aumentou em $231 \%$, em médias $162 \%$ e em pequenas $24 \%{ }^{168}$. O número de trabalhadores ocupados em pequenas indústrias representava $59 \%$ do total em 1882; $47 \%$ em 1895 e $37 \%$ em 1907, tendo sofrido, contudo, um aumento em termos absolutos, passando de 4,3 milhões para 5,4 milhões de trabalhadores. Simultaneamente, o número de trabalhadores ocupados em médias empresas teria aumentado, em termos absolutos, de 1,4 milhões para 3,6 milhões, compreendendo, em 1882, $19 \%$ do total; $24 \%$ em 1895 e $25 \%$ em $1907^{169}$. Já as grandes empresas concentravam, em 1882, $22 \%$ da mão-de-obra total, em 1895, 30\% e em 1907, 37\%, o que significava um impressionante aumento absoluto de 1,6 milhões para 5,4 milhões de trabalhadores $^{170}$.

A inigualável taxa de crescimento apresentada pela Alemanha nos anos 90 refletia não apenas a rápida expansão da produção industrial de bens de consumo e capital, mas também o florescimento do capital financeiro e a recuperação da produção agrícola, favorecida pela montagem de uma ampla rede de transporte ferroviário e pelo crescimento populacional.

O sucessor de Bismarck ${ }^{171}$, o chanceler Georg Leo von Caprivi, manteve o alto nível de crescimento ao longo dos anos noventa, procurando equilibrar as tensões e conciliar os

\footnotetext{
${ }^{165}$ Bo Gustaffson (1975, p.20) nos apresenta a seguinte evolução do número de cartéis: 14 em 1879, 90 em 1885 , 210 em 1890, 260 em 1896 e, finalmente, 366 em 1905.

166 Tanto os bancos de investimentos como os bancos comerciais, hipotecários e caixas econômicas, envolveramse no financiamento da atividade econômica local, concedendo empréstimos hipotecários, apólices municipais, títulos do governo e créditos comerciais (Cf. RODES, John E. Germany: a history. New York: Holt, Rinehart and Winston, 1964, p.382).

${ }^{167}$ GAY, Peter. The dilemma of democratic socialism. New York: Columbia University Press, 1970, p. 126.

${ }^{168}$ Gustafsson, 1975, p.20.

${ }^{169}$ Ibid.

${ }^{170}$ Jacques Droz (1974, p.555) assinala que a mão-de-obra industrial na Alemanha teria passado de 7.300.000, em 1882, a 10.200.000, em 1895, ou seja, teria acrescido em $40 \%$.

${ }_{171}$ Após a destituição de Bismarck em 1890, o cargo de chanceler foi ocupado por Georg Leo von Caprivi (de 1890 a 1894), Chlodwig Karl Viktor zu Hohenlohe-Schillingsfürst (de 1894 a 1900), Bernhard von Bülow (de 1900 a 1909), Theobald von Bethmann-Hollweg (de 1909 até 14 de julho de 1917) e finalmente Georg Michaelis (que permanece até 30 de agosto de 1917, quando há o final do Império).
} 
interesses dos grandes proprietários rurais (reunidos no Bund der Landwirte ${ }^{172}$ - criado em 1893) e dos capitalistas industriais. Contudo, Caprivi não obteve sucesso neste empreendimento, na medida em que se viu obrigado a apoiar as demandas de livre-comércio da burguesia industrial e financeira e a firmar acordos comerciais com oito nações européias válidos por um período de doze anos - que incluíam a redução das tarifas de importação de grãos. Esta iniciativa reavivou o descontentamento dos grandes proprietários rurais provocando um racha entre os partidos que apoiavam o governo.

Com vistas à reconquista do apoio dos conservadores, foram promulgadas, em 1902, leis tarifárias que reduziam o imposto sobre a terra e forneciam crédito facilitado para proprietários de terra. Estas medidas geraram um aumento nos preços dos gêneros alimentícios, agravado devido à implementação de uma política protecionista em 1905. Como conseqüência, as eleições de 1903 representaram uma grande vitória para a social-democracia, que contou com o apoio das massas populares insatisfeitas. Este fato levou à dissolução do Reichstag e a convocação de novas eleições. Na nova assembléia de 1906, o bloco antisocialista - composto por conservadores, nacionais-liberais, progressistas e anti-semitas detinha a maioria dos assentos: 203 dos $397^{173}$.

A mesma estratégia de conciliação entre a nobreza fundiária e a burguesia industrial e financeira foi aventada por Bernhard von Bülow, a partir de 1900, consubstanciada em sua tentativa de composição de um bloco formado por forças pró-governistas, como medida para conter os avanços da social-democracia. Assim como Caprivi, Bülow enfrentou uma série de problemas em manter o bloco liberal-conservador unido, o que culminou em sua deposição pelo Imperador em 1909.

Não obstante a sua divergência quanto à política tarifária, tanto os grandes proprietários de terras quanto as emergentes classes industriais foram extremamente beneficiados pelo progresso econômico do período, alcançando patamares inéditos de acumulação. Por outro lado, o processo de consolidação do capitalismo na Alemanha gerou um incremento no nível de insegurança de trabalhadores do campo e da cidade. Embora os índices de desemprego durante toda a década de 1890 tenham se mantido extremamente baixos - variando de 3 e $6 \%$ entre 1891 e 1895 ; e de 1 a $1,5 \%$ entre 1895 e $1900^{174}$ - e a queda dos preços dos gêneros alimentícios tenha proporcionado um aumento relativo dos

\footnotetext{
172 "Liga dos Proprietários Rurais".

${ }^{173}$ Cf. Rodes, 1964.

${ }^{174}$ Gustaffson, 1975, p.23.
} 
salários, recuperando o poder aquisitivo dos assalariados urbanos, isto não repercutiu na melhora no padrão de vida das classes trabalhadoras de maneira geral.

A ruína dos pequenos camponeses, iniciada com a dissolução do regime comunal e da rotação obrigatória dos cultivos, os impeliu, juntamente com os assalariados do campo ${ }^{175}$, a engrossarem as fileiras do proletariado urbano ${ }^{176}$. A retração do emprego no campo - que em 1871 concentrava até $60 \%$ dos trabalhadores ${ }^{177}$, ocasionada pela mecanização das técnicas de cultivo e pela falência de pequenos proprietários, conduziu grandes contingentes populacionais para as cidades ${ }^{178}$. Weber, em artigo intitulado "Capitalismo e sociedade rural na Alemanha", procurou esclarecer esta tendência:

Quanto mais a indústria alemã crescia no oeste, até atingir seu volume presente, tanto mais a população sofria uma enorme modificação; a emigração alcançou seu auge no leste alemão, onde apenas senhores e servos existiam em distritos demasiado amplos e dos quais os trabalhadores agrícolas fugiam, buscando livrar-se do isolamento e da dependência patriarcal, seja atravessando o oceano para os Estados Unidos, seja para o ar fumarento e poeirento, mas socialmente livre, das fábricas alemãs ${ }^{179}$.

Com efeito, enquanto os postos de trabalho na indústria e no comércio aumentaram, no campo a situação foi inversa. Em 1895, 36\% dos trabalhadores trabalhavam na agricultura, quase $40 \%$ na indústria e $12 \%$ nas áreas de comércio e comunicação, sendo o restante dividido entre funcionários do governo ou outros serviços ${ }^{180}$.

\footnotetext{
${ }^{175}$ Os trabalhadores agrícolas, por sua vez, encontrar-se-iam em estado de miséria ainda maior. Fracionados e dispersos, estes integrariam em grande número os "exércitos" dos monarcas, enviando ao Reichstag a maioria dos antigos senhores feudais e junkers.

${ }^{176}$ MARX, K, ENGELS, F. "Contribuição ao problema da habitação”. In Obras escolhidas. São Paulo: AlfaOmega, v.2, 1980b, p.114.

${ }^{177}$ Rodes, 1964, p.381.

178 Marcelo Ramanosk (2005, p.42) apresenta os seguintes dados relativos à porcentagem da população: 1871população total: 41.059.000, porcentagem rural: $63,9 \%$, porcentagem urbana: $36,1 \%$; 1880- população total: 45.234.000, porcentagem rural: 58,6\%, porcentagem urbana: 41,4\%; 1890- população total: 49.428.000, porcentagem rural: $57,5 \%$, porcentagem urbana: $42,5 \%$; 1900- população total: 56.367 .000 , porcentagem rural: $45,6 \%$, porcentagem urbana: $54,4 \% ; 1910$ - população total: 64.926 .000 , porcentagem rural: $40 \%$, porcentagem urbana: $60 \%$.

179 WEBER, Max. "Capitalismo e sociedade rural na Alemanha". In: Ensaios de Sociologia. Coleção Os pensadores. São Paulo: Abril Cultural, 1974, p.111.

180 A população cresceu cerca de $33 \%$ entre 1882 e 1902, já a força de trabalho industrial e manufatureira cresceu 180\%, até atingir 8,5 milhões de pessoas, ou 35\% de uma força de trabalho ativa de 27 milhões. Desses assalariados, 2,7 milhões (10\%) estavam empregados em ferro e aço, metalurgia, construção de veículos e indústrias químicas; 1,2 milhão na indústria extrativa; 1,1 milhão nos transportes; e 4,5 milhões indústria de bens de capital, mineração e transportes (17\% do total da força de trabalho ativa). O setor terciário vinculado ao comércio e serviços, profissões liberais, serviço doméstico também sofreu uma grande expansão. Entre 18951907 o número de estabelecimentos varejistas aumentou em $42 \%$ e o número de empregados em 55\% (Mayer,
} 
O êxodo rural somado à queda das taxas de mortalidade e à diminuição da emigração acarretou um considerável crescimento populacional urbano. Entre 1871 e 1890 a população alemã aumentou de 41 milhões para mais de 49 milhões. Em 1900 chegou a mais de 56 milhões e em 1910 atingiu 64 milhões - apesar da emigração de mais de 2 milhões de alemães $^{181}$. Assim, o número de grandes cidades alemães em 1890, comparado ao início da década de 50, dobrou, além de suas populações terem triplicado de tamanho ${ }^{182}$.

A concentração populacional nas grandes cidades determinou a criação de novas tarifas, o aumento no custo de vida (decorrente principalmente da alta nos preços dos grãos) e o agravamento da questão habitacional. Engels - que já havia analisado este mesmo processo em "A situação da classe operária na Inglaterra", escrito em 1844 - nos apresenta um panorama dos efeitos da concentração urbana em uma série de três artigos escritos entre 1872 e 1873, publicados no Volkstaat sob o título "Contribuição ao problema habitacional”:

A época em que um país de antiga cultura realiza essa transição - além do mais, acelerada por circunstâncias tão favoráveis - da manufatura e da pequena produção à grande indústria, acontece ser também uma época de "penúria da habitação". Por um lado, massas de operários rurais são atraídas subitamente para as grandes cidades, que se convertem em centros industriais; por outro lado, o traçado daquelas velhas cidades já não corresponde às condições da nova grande indústria nem ao seu grande movimento; as ruas são alargadas, abrem-se novas ruas, as ferrovias passam por elas. No momento mesmo em que os operários afluem em grande número às cidades, as habitações são destruídas em massa. Daí a repentina penúria de habitação para o operário, o pequeno comerciante e o artesão, que dependem da clientela operária ${ }^{183}$.

A afluência repentina para as grandes cidades e o agravamento das condições sociais da classe trabalhadora são vistos por Engels como conseqüências necessárias do processo de desenvolvimento do modo de produção capitalista. Deste modo, a escassez da habitação, o aumento no preço dos aluguéis, a aglomeração e superlotação de inquilinos, as precárias condições sanitárias, o ambiente insalubre dos bairros operários (focos de epidemias de

1987, p.80). Apenas 10 milhões de trabalhadores, numa força de trabalho ativa de 27 milhões, ou seja, $30 \%$ estavam empregados na manufatura e na indústria (Mayer, 1987, p.46).

${ }^{181}$ Rodes, 1964, p.381.

${ }^{182}$ A quantidade de cidades alemãs com mais de 10.000 habitantes em 1800 seria 53; em 1850, 133; e em 1890, 382. Já a porcentagem da população urbana total seria em 1800, 5,5\%; 1850 - 10,8\%; 1890- 28,2\% (Hobsbawm, 2005, p. 472). Já as cidades com mais de 100.000 habitantes passariam de 8 em 1871, para 26 em 1890 (Rodes, 1964, p. 381).

183 MARX, K, ENGELS, F. "Segundo prefácio à "Contribuição ao problema da habitação". In Obras escolhidas. São Paulo: Alfa-Omega, v.2, 1980b, p. 107. Escrito por Engels em 1887. 
cólera, tifo, febre tifóide e varíola) e o deslocamento dos bairros operários do centro para a periferia não poderiam ser remediados através de reformas sociais pontuais, meros paliativos alentados pelo socialismo burguês e pequeno-burguês que não alterariam a base fundamental da ordem social capitalista ${ }^{184}$.

Enquanto as condições da classe operária nas cidades se agravavam, no campo a situação não era muito diferente. A miséria crescente dos pequenos camponeses e o avanço da moderna indústria alemã compeliram para que fosse estendida continuamente a indústria a domicílio rural $^{185}$. Desta forma, cada vez mais os pequenos camponeses encontrar-se-iam em situação mais caótica, recorrendo a agiotas na esperança de salvarem sua propriedade. Conforme observou Engels,

Vemos aqui claramente como, o que numa etapa anterior era a base de um bem-estar relativo dos operários - a combinação do cultivo e da indústria, a posse de uma casa, de uma horta e de um sítio, a segurança de uma habitação - hoje, sob o reinado da grande indústria, converte-se não somente na pior das cadeias para o operário, mas também na maior desgraça para toda a classe operária, na base de um descenso sem precedentes do salário abaixo de seu nível normal. E isso não apenas em alguns ramos da indústria ou em regiões isoladas, mas em escala nacional $^{186}$.

Para Engels, a precária condição de vida existente no campo poderia levar principalmente os assalariados rurais a apoiarem a causa proletária. Deste modo, caberia à social-democracia despertar a sua consciência de classe e incorporá-los ao movimento, pois "no dia em que a massa de operários agrícolas aprender a ter consciência de seus próprios interesses será impossível existir na Alemanha um governo reacionário, seja feudal, burocrático ou burguês"

Cabe ressaltar que, ao contrário de Engels, que destacara a tendência ao declínio da pequena propriedade rural, Weber alegou que haveria uma "superioridade econômica" do pequeno agricultor sobre a agricultura de larga escala, devido à intensidade e alta qualidade de seu trabalho e à adaptabilidade às exigências do mercado local ${ }^{188}$. Isto determinaria, portanto, a sobrevivência e prosperidade das pequenas propriedades rurais e manufaturas, mesmo diante do desenvolvimento das produções em larga escala. Weber, portanto, desconsiderou o

\footnotetext{
${ }^{184}$ Ibid., p.116.

${ }^{185}$ Ibid., p.111.

${ }^{186}$ Ibid., p.113.

187 MARX, K, ENGELS, F. "Prefácio à 'Guerra Camponesa na Alemanha””. In Obras escolhidas. São Paulo: Alfa-Omega, v.2, 1980b, p.197. Escrito por Engels em 1870.

${ }^{188}$ Weber, 1974, p.104-113.
} 
argumento de Engels de que a conservação das pequenas propriedades rurais se deu às custas do empobrecimento e precarização da situação destes proprietários.

Como é possível constatar, a peculiar conjuntura econômica, política e social dos fins do século XIX e início do século XX proporcionou condições favoráveis à expansão do movimento operário alemão. Sua independência em relação às classes burguesas - aliadas ao governo semi-autocrático -, o desenvolvimento industrial e o crescimento das cidades, combinados à elevação no nível de instrução dos trabalhadores urbanos ${ }^{189}$ e o contato com um farto volume de materiais fornecidos pela imprensa socialista, foram fatores importantes para os extraordinários avanços do Partido Social-Democrata Alemão nos marcos da emergente sociedade capitalista. A seguir analisaremos o papel que o SPD veio a assumir no âmbito desta sociedade em vias de transformação e a sua própria modificação diante destas novas circunstâncias.

\section{2- Os novos desafios decorrentes da legalização do partido}

Conforme assinalado por Marx e Engels, a guerra de 1870-71 e a derrota da Comuna de Paris transferiram, ao menos provisoriamente, o centro de gravidade do movimento operário europeu da França para a Alemanha ${ }^{190}$. O patente avanço industrial alemão possibilitou a constituição de "um poderoso exército do proletariado" que, de acordo com Engels, estaria "incessantemente em progresso, crescendo dia a dia em número, organização, disciplina, clarividência e certeza da vitória"191. Já em 1892, Engels anunciava entusiasticamente:

Os progressos alcançados aqui há vinte e cinco anos não têm precedentes. $\mathrm{O}$ movimento operário alemão avança a uma velocidade acelerada. E se a burguesia alemã tem dado provas de sua ausência lamentável de capacidade política, de disciplina e perseverança, a classe operária da Alemanha demonstrou que possui em grau extraordinário todas essas qualidades. (...) No ponto em que se acham as coisas, será despropositado pensar

\footnotetext{
${ }^{189}$ Segundo Hobsbawm (2005, p.474), a taxa de analfabetismo entre os adultos, que em 1850 já era inferior a $30 \%$, em 1913 cai para menos de $10 \%$.

${ }^{190}$ ENGELS. "Introdução a "Luta de classes na França (1848-1850)". In: Obras escolhidas. São Paulo: AlfaOmega, v. 1, 1980a , p.101.

${ }^{191}$ Ibid, p. 99.
} 
que a Alemanha venha a se tornar também o cenário do primeiro grande triunfo do proletariado europeu ? $^{192}$

A suplantação das dissidências internas entre lassalleanos e marxistas e a conjugação de forças na criação de um novo partido - cujos princípios encontravam-se definidos no Programa de Gotha ${ }^{193}$ - dotado de uma única direção e organização, malgrado suas contradições latentes, favoreceram o trabalho de propaganda e cooptação, trazendo para as fileiras da social-democracia parte significativa dos proletários urbanos, principalmente aquela formada pelos residentes nas grandes cidades.

Contudo, o persistente e ordenado esforço de difusão do socialismo e da promoção da luta de classes enfrentava inúmeros e relevantes obstáculos. O primeiro desafio a se impor à social-democracia consistia justamente na mobilização dos trabalhadores e na formação de sua consciência de classe. Como aponta Adam Przeworski em seu livro "Capitalismo e socialdemocracia", o processo de auto-educação e construção de sua solidariedade de classe era dificultado pela fragmentação e concorrência presentes entre os próprios trabalhadores. Repetindo o célebre argumento já esboçado por Kautsky e Lênin ${ }^{194}$, o autor destaca a importância do partido para a superação das particularidades e fracionamentos internos da classe operária, de modo a propiciar a adesão dos trabalhadores ao socialismo:

Os operários individuais, bem como os relacionados a uma firma ou setor específico, têm um poderoso incentivo para lutar por seus interesses particulares em detrimento de outros operários na ausência de alguma organização - sindicato, partido ou Estado diretamente - com poderes para impor a disciplina coletiva. Portanto, para superar a competição, os operários precisam organizar-se como uma força coletiva. ${ }^{195}$

Sob este prisma, a transformação da "classe em si" em "classe para si", o despertar dos trabalhadores para sua missão histórica e o desenvolvimento de suas potencialidades revolucionárias exigiam, portanto, um longo e demorado processo de aprendizagem e $\operatorname{organização~}^{196}$. Ao partido caberia o papel de incitar a coesão, a combatividade e a

192 ENGELS. "Prefácio à edição inglesa de "Do socialismo utópico ao socialismo científico"”. In: Obras escolhidas. São Paulo: Alfa-Omega, v. 2, 1980b , p. 302. v.220/4/1892,

193 O Programa de Gotha vigeu de 1875 a 1891. Cf. Capítulo 1: "As origens da social-democracia e sua unificação em torno do Programa de Gotha".

${ }^{194}$ LENINE. “Que fazer?”. In: Obras escolhidas. $3^{\mathrm{a}}$ ed. São Paulo: Alfa-Omega, v. 1, 1986.

${ }^{195}$ PRZEWORSKI, Adam. Capitalismo e social-democracia. São Paulo: Companhia das Letras, 1989, p.35.

196 Convém ressaltar que a partir de 1905, Rosa Luxemburg contestará tal concepção, ressaltando que a consciência de classe não é algo a ser introduzido a partir de fora - por uma vanguarda do partido - mas sim o resultado da práxis, da própria experiência ativa da classe operária imersa na luta (Cf. LUXEMBURG, Rosa. Oeuvres I (Reforme ou révolution? Grève de masse, parti et syndicats). Paris: François Maspero, 1969). 
identificação dos trabalhadores com sua classe, suscitando a modificação de seu comportamento político. Assim, através da agitação política os social-democratas esperavam "atrair a atenção das camadas de operários mais amplas e mais atrasadas para as questões políticas e sociais", associando a luta econômica contra o patronato e o governo à luta política $^{197}$.

A fim de estimular o ímpeto revolucionário das massas trabalhadoras fazia-se igualmente necessário combater a influência ideológica exercida pelas instituições controladas pelas classes dominantes, como a escola, o exército e as associações sindicais de caráter burguês e pequeno-burguês ${ }^{198}$. A criação de sindicatos desatrelados à política conservadora e assistencialista do governo foi, portanto, um dos pontos cruciais na luta pela superação da reificação das relações sociais e das ilusões quanto às possibilidades proporcionadas por um Estado social e de direito. Com efeito, os Sindicatos Livres - que, norteados pelos ideais da social-democracia, visavam minar a resistência ao socialismo ${ }^{199}$ e a desatenção em relação à política - tiveram um crescimento estrondoso no final do século XIX, reunindo cerca de 90.000 trabalhadores em 1888, 294.000 em 1893, 680.000 em 1900 e 2.500 .000 em $1914^{200}$. Ademais, a base social - composta principalmente por mineiros, metalúrgicos e trabalhadores das indústrias de construção, transportes, tecidos e madeiras ${ }^{201}$ - e a estrutura centralizadora dos sindicatos de massa permitiam a coordenação e a vinculação entre estes e o Partido Social-Democrata.

Não obstante a incrível expansão dos Sindicatos Livres, estes ainda enfrentavam a forte concorrência das sociedades de artesãos (gráficos, carpinteiros, pedreiros, luveiros, ferreiros, moldadores, etc. ${ }^{202}$ ) e de associações profissionais localistas ${ }^{203}$ e religiosas. $\mathrm{Na}$

\footnotetext{
${ }^{197}$ Lenine, 1986, p.160.

${ }^{198}$ Como as organizações de Schulze-Delitzch, membro do Partido Progressista e criador de associações de crédito, cooperativas de consumo e de matérias-primas e fundos de ajuda mútua. De acordo com Lassalle, até 1863 Schulze havia instituído 450 cooperativas de crédito, 150 de matérias-primas e entre 30 e 40 cooperativas de consumo (LASSALLE, Ferdinand. Manifesto operário e outros textos. Brasília: Instituto Teotônio Vilela, 1999, p.122).

${ }^{199}$ A este respeito, cabe destacar a observação de Adam Przeworski: "De fato, a dificuldade inicial enfrentada pelos socialistas foi a desconfiança dos trabalhadores com relação a quaisquer influências originadas fora de sua classe. O socialismo parecia uma ideologia abstrata e alienígena em comparação com sua experiência cotidiana. Para os operários, não era evidente que uma melhora em suas condições requeria a abolição do próprio sistema salarial" (Przeworski, 1989, p.37).

${ }^{200}$ Gustafsson, 1975, p.21.

${ }^{201}$ ELEY, Geof. Forjando a democracia: a história da esquerda na Europa, 1850-2000. São Paulo: Fundação Perseu Abramo, 2005, p.99-102. Confira a tabela 2, em anexo, que apresenta as organizações sindicais criadas na Europa com o apoio dos partidos social-democratas, até o final do século XIX.

${ }^{202}$ Eley, 2005, p.99.
} 
Alemanha, as condições decorrentes da unificação política e territorial do Império - composto pela anexação e incorporação de trinta e seis Estados ${ }^{204}$ - suscitaram a formação de inúmeras minorias nacionais. A diversificação cultural, étnica e religiosa deu origem a pequenos partidos e organizações sindicais de alcance local ou regional que representavam um sério empecilho ao avanço da social-democracia ${ }^{205}$.

A dificuldade em conquistar os votos dos católicos em Estados como a Renânia, a Baviera e a Prússia (particularmente na Silésia e na Westfalia), além das cidades industriais do Ruhr, era patente ${ }^{206}$. A influência do "catolicismo social", principalmente entre camponeses e membros das classes médias baixas, resultou na formação de variadas associações assistencialistas de caráter religioso. Nas regiões católicas foram criadas organizações abertamente hostis aos socialistas como o Volksverein für das katholische Deutschland, cuja sede era situada em München-Gladbach.

Os inumeráveis Arbeitervereine católicos, sob o controle de clérigos, e os sindicatos cristãos (Christliche Gewerkschaften), organizados em uma União Geral, condenaram em seu congresso de 1899 a doutrina da luta de classes e defenderam a associação do trabalho e do capital sobre uma base profissional, em consonância com as diretrizes oficiais da Igreja. Embora a Encíclica Rerum Novarum, enunciada pelo Papa Leão XIII ${ }^{207}$ em 1891, criticasse os excessos do liberalismo econômico, condenava o socialismo e os sindicatos, exortando a classe trabalhadora a não aderir a greves e a revitalizar corporações artesanais como forma de

203 Segundo Eley, em 1895, 45\% dos operários sindicalizados de Berlim ainda estavam em sindicatos locais, reunidos na Aliança Livre (FVDG), cuja base era de trabalhadores em construção e mecânica. Já em 1907-8, os metalúrgicos foram integrados ao sindicato nacional, levando ao fechamento da FVDG (Ibid, p.101).

${ }^{204}$ Confira o mapa em anexo (figura 1), que evidencia as anexações de territórios da França, Dinamarca, Áustria e Bélgica.

${ }^{205}$ A implantação da social-democracia na Alsácia-Lorena se deu de modo mais fácil, pois nestas regiões a reivindicação por autonomia e livre determinação permitiram conquistar o assento de Mulhouse desde 1890, o de Strasbourg em 1893, e dispor de 5 assentos no Reichstag (STONE, Norman. La Europa transformada 18781919. Madrid: siglo veintiuno, 1985, p. 204).

${ }^{206}$ Com vistas a atrair as minorias nacionais, o SPD chegou a criar um órgão especial para os trabalhadores poloneses (cerca de 3.000.000) das minas do Ruhr e da Alta Silésia: “A Gazeta do Trabalho" (Gazeta Robotnicza) e, sob o controle do partido, foi criado em 1893 um Partido Socialista Popular da Prússia (PPS), que recebeu seus próprios organismos e estruturas. Contudo, em 1902 e 1906 as relações entre os dois partidos foi rompida (cf. Stone, 1985, p.104).

${ }^{207}$ Segundo Arno Mayer "como um tradicionalista tolerante, o papa Leão XIII (1878-1903) condenava o erro exegético e tentava chegar a um acordo com a nova ordem, que, segundo esperava, traria "imensos benefícios" a toda a humanidade e não só aos "povos civilizados"”. Ao mesmo tempo em que censurava a intemperança do liberalismo econômico e social, a usura, os lucros e as fortunas desmedidas dos capitalistas e lamentava a miséria e a superexploração dos trabalhadores, denunciava os socialistas e seus sindicatos como "irreligiosos" e aproveitadores da situação difícil do proletariado. Declarou ainda a propriedade privada inviolável e "componente da ordem natural de Deus", cabendo ao Estado a proteção dos proprietários legais contra a espoliação (Mayer, 1990, p.241). Esta ojeriza aos socialistas se agravou durante o severo pontificado de Pio X (1903-1914). 
enfrentar os abusos do capitalismo ${ }^{208}$. A criação do Partido do Centro (Zentrumpartei) em 1870 e a amenização da Kulturkampf na década de 80 permitiram que os católicos pudessem levar adiante uma política no Reichstag até certo ponto independente, ora constituindo o "bloco azul e negro" - através da aliança com os conservadores - ora integrando o "bloco vermelho e negro" - contando com o apoio de social-democratas.

Tal como os católicos, os protestantes também criaram suas organizações próprias. A sudoeste da Alemanha o "protestantismo social" do Deutsche Protestanteverein proliferou. Associações mais conservadoras e dogmáticas foram criadas no final da década de 1880, como o Partido Social Cristão, liderado pelo pastor Adolf Stöcker. Marcado por idéias antisemitas este "movimento cristão-social" (christlich-sozial), de base pequeno-burguesa, opunha-se a judeus, progressistas e social-democratas, em nome da defesa de valores cristãos e germânicos. Em seu programa de 1892 demandavam a luta incondicional contra os socialdemocratas - considerados inimigos do Estado - e o sufrágio universal ${ }^{209}$.

Além dos fatores profissionais, nacionais e religiosos, a desarticulação dos trabalhadores ainda era agravada pelo sistema político e eleitoral vigente na Alemanha. Cada Estado do Império possuía sua própria Constituição e determinava os limites da atuação política legal. A Constituição da Prússia, outorgada em 1850, estabelecia, por exemplo, o "sistema das três classes" nas eleições para o Parlamento local (Landtag), segundo o qual os eleitores (exclusivamente do sexo masculino) eram divididos de acordo com o montante de impostos pagos.

Não bastassem as distorções ${ }^{210}$ provocadas por este sistema, o voto era indireto e aberto, o que dava margem a fraudes e à corrupção, além de enfraquecer a posição política dos social-democratas, que se viam obrigados a apoiar liberais e católicos no segundo turno das eleições ${ }^{211}$. A política de alianças, contudo, era repudiada pela maioria do SPD, pois implicaria a assunção de compromissos que poderiam comprometer o caráter proletário do partido.

Se em alguns Estados os social-democratas encontravam grandes dificuldades para a participação no Parlamento local, no âmbito federal realizaram grandes conquistas nas

\footnotetext{
${ }^{208}$ Stone, 1985, p.204-205.

${ }^{209}$ Ibid, p. 204.

${ }^{210}$ Isabel Maria Loureiro nos lembra do conhecido caso de um fabricante de salsichas que constituía o único eleitar da $1^{\mathrm{a}}$ classe na $58^{\mathrm{a}}$ seção eleitoral de Berlim (LOUREIRO. A Revolução Alemã, 1918 - 1923. São Paulo: UNESP, 2005, p.28).

${ }^{211} \mathrm{O}$ apoio a candidatos de outros partidos no segundo turno das eleições foi aprovado no Congresso de Halle, de 1890.
} 
eleições para o Reichstag, cujos membros eram eleitos em eleições diretas, por sufrágio masculino (aos maiores de 25 anos), e cumpriam um mandato de 5 anos. Mesmo durante a vigência da legislação proibitiva os resultados obtidos pelo SPD eram impressionantes ${ }^{212}$.

Apesar da intensa e permanente vigilância e intervenção do governo, a socialdemocracia manteve sua trajetória ascendente, ganhando cada vez mais espaço no cenário político germânico. Já em 1890, o SPD conseguiu superar o número de votos recebidos por todos os demais partidos ${ }^{213}$ : o Zentrumpartei católico, o Volkspartei ${ }^{214}$ (composto por liberais de esquerda), o Nationalliberale Partei (integrado por liberais de direita e conservadores ${ }^{215}$ ), o Partido Conservador ${ }^{216}$ (composto por Junkers prussianos e nacionalistas que reivindicavam tarifas protecionistas), o Partido Conservador Independente ${ }^{217}$ (que, além de proprietários de terras, reunia industriais e capitalistas do Ruhr) e o Reichspartei.

Cabe ressaltar que as eleições para o Reichstag baseavam-se em circunscrições distritais já obsoletas em termos de representação populacional. Como consequiência, os distritos agrícolas - onde predominava a influência dos católicos e de conservadores continuavam a deter grande peso político, apesar do crescimento das grandes $\operatorname{cidades}^{218}$. A despeito do prejuízo causado pela defasagem do sistema de representação eleitoral - baseado no censo realizado ainda na década de 1860 - a social-democracia avançava a olhos vistos.

A revogação da legislação anti-socialista em setembro de 1890 e o arrefecimento da repressão praticada pelo exército e pela polícia permitiram aos social-democratas aperfeiçoarem e expandirem sua organização e repensarem sua tática política de pura oposição e isolamento em relação a outros partidos. Tal tática incluía a oposição sistemática ao governo mediante a rejeição dos créditos solicitados pelo governo e a recusa a apresentar candidatos a cargos parlamentares - o que ocorreu efetivamente em 1912, quando Scheidemann ocupou o cargo de vice-presidente do Parlamento.

\footnotetext{
${ }^{212}$ Confira o gráfico 1 e a tabela 1 , em anexo.

${ }^{213}$ Existiam ainda muitos pequenos partidos regionais, que em geral constituíam uma quinta parte do parlamento alemão.

${ }^{214}$ Em 1910 passa a se chamar Partido Progressista (Fortschrittliche Volkspartei). Defendia a liberdade de comércio, a subordinação do Exército a um governo civil e o liberalismo político e econômico.

${ }^{215}$ Em geral, seus membros vinham do Partido Progressista, tendo retido alguns ideais liberais; seus interesses residiam no comércio e na indústria.

${ }^{216}$ O Partido Cristão-Social fundado em 1878 pelo pastor Adolf Stöcker para afastar os trabalhadores da socialdemocracia não teve sucesso, tendo sido transformado, em 1881, em uma organização anti-semita destinada à pequena burguesia e que funcionava nos quadros do Partido Conservador.

${ }^{217}$ O Partido Conservador Independente se separou do Partido Conservador em 1866.

218 Por exemplo, em 1912 Schoumburg-Lippe (com 10.707 habitantes) e Berlim (com 104.460) possuiam o mesmo número de representantes no Reichstag (Rodes, 1964).
} 
No Congresso de Halle de 1890 foi criado um novo Estatuto para o partido, tendo sido rejeitada a proposta redigida pela facção parlamentar que concentrava os poderes decisórios justamente nas mãos dos representantes parlamentares ${ }^{219}$. Foi estabelecido, então, que a organização partidária seria composta por um Congresso anual de delegados, eleitos dentro das mesmas condições que os "homens de confiança", um Diretório partidário (Vorstand), composto por militantes eleitos pelo Congresso, e um jornal oficial - o Vorwärts. Além disto, seriam indicados 12 membros (Partei Leitung) pelo Congresso para supervisionar a execução da política e a administração do partido ${ }^{220}$.

O Congresso de Halle discutiu ainda sobre a possível expulsão do "Grupo dos Jovens", que viria a se concretizar no congresso seguinte - o Congresso de Erfurt ${ }^{221}$. Neste sentido, os líderes do SPD posicionaram-se favoravelmente à luta política, condenando tanto as facções anarquistas presentes no partido, representadas por Paul Pawlowitsch e Gustav Landauer, quanto os "Jovens" (Jungen) $)^{222}$, que criticavam o "aburguesamento" do partido e a sua transformação em um aparelho oligárquico com propósitos próprios.

Nesta ocasião, Liebknecht realizou uma contundente defesa da ação política parlamentar e da utilização dos direitos políticos e da máquina legislativa para a luta em prol dos interesses imediatos do proletariado, ao declarar: "em lugar de falar incessantemente da revolução, é muito mais positivo trabalhar para conseguir melhorar a sorte do proletariado e fortalecer a organização operária; esta é a forma de servir eficazmente à causa popular,223.

Ao relegar a revolução ao segundo plano, Liebknecht deixou clara sua adesão à orientação reformista, fato que teve sérias implicações dentro do partido ao longo da década de 90. A dissociação entre objetivos a curto prazo (meios) e objetivos a longo prazo (fins) resultou na exaltação do pragmatismo, anteriormente pregado pelas correntes lassalleanas -

\footnotetext{
${ }^{219}$ Cf. SCHORSKE, Carl E. German social democracy. 1905- 1917: The development of the great schism. New York: Harper Torchbooks, 1972.

${ }^{220}$ Cf. DROZ, Jacques. Histoire générale du socialisme - tomo II. Paris: Presses Universitaires de France, 1974.

${ }^{221}$ O Congresso de Erfurt é considerado o marco de origem do Sozialdemokratische Partei Deutschlands (SPD), no qual foi aprovado um novo Programa, desta vez fortemente orientado pela doutrina marxista. Em sua parte teórica são analisados os problemas decorrentes do desenvolvimento do modo de produção capitalista na Alemanha: a monopolização dos meios de produção, a polarização das classes, a ruína das classes médias e a multiplicação das crises, além do papel emancipador da classe operária e o internacionalismo proletário. Em sua parte prática são listadas as reivindicações imediatas dos social-democratas: o sufrágio direto universal e estendido às mulheres, a separação entre Estado e Igreja, a laicidade da escola, o imposto progressivo, uma legislação social que inclua a lei das oito horas, a proibição do trabalho infantil a menores de 15 anos, um seguro ao trabalhador a cargo do Estado e o respeito ao direito de coalizão (Marx; Engels; Lênin, 1971).

${ }^{222}$ Após sua expulsão do partido, Paul Ernst, Max Schippel, Paul Kampffmeyer, Bruno Wille e Hans Müler formaram o Partido Socialista Independente, que teve uma curta duração (Gustafsson, 1975, p.22).

${ }^{223}$ JOLL, James. La Segunda Internacional. Movimiento obrero 1889-1914. Barcelona: Icalia, 1976, p. 70.
} 
que, nas palavras de Marx, "aceitavam como coisas reais, somente os interesses imediatos que tem à sua frente"224. Este "caminho falso" da Realpolitik, agora percorrido por Liebknecht, ia de encontro ao princípio de que "a classe operária pela própria natureza das coisas deve ser sinceramente revolucionária"225.

Convém ressaltar que, conquanto as tarefas cotidianas fossem necessárias e até mesmo indispensáveis para se galgar a melhoria das condições de vida do proletariado e evitar o resvalo em uma atitude quietista e passiva, ainda que encoberta por uma fraseologia "revolucionária", por outro lado, a obliteração do objetivo revolucionário e das exigências colocadas em função da luta de classes no decorrer do processo de transformação radical da sociedade - que podem estar inclusive em conflito com demandas e reivindicações imediatas - levou líderes socialistas de vários países - como Jaurés, Brousse e Millerand na França - a assumirem uma postura de endosso e acomodação ao modo de produção capitalista, entregando-se inteiramente ao jogo político parlamentar e às regras impostas pelas classes dominantes.

Embora o reformismo desse sinais de revigoramento no seio do SPD, Engels, em carta a Conrad Schmidt ${ }^{226}$, reforçou a atitude de reprovação aos "Jovens". A seu ver, mesmo sendo evidente o predomínio de elementos oriundos da pequena-burguesia ${ }^{227}$, os "Jovens" estariam incorrendo em um sério equívoco ao considerarem a composição pequeno-burguesa do partido como sendo a indicação de uma pré-disposição à burocratização e ao reformismo, recaindo assim em um determinismo e um desprezo pelas condições históricas:

O que falta nesses senhores é a dialética. Eles sempre enxergam apenas causa aqui, efeito acolá. Que isso é uma abstração vazia, que no mundo real esses pólos antinômicos metafísicos só existem em crises, que todo o grande percurso ocorre sob a forma de interação - ainda que de forças desiguais, das quais o movimento econômico é, de longe, a mais forte, primordial, decisiva - , que aqui nada é absoluto e tudo é relativo, isso tudo eles não enxergam de jeito nenhum, para eles Hegel não existiu. (...) nunca vi, em lugar algum, uma trapalhada de material tão imaturo e de imbecilidade absoluta como a que essa oposição faz aflorar. Esses jovens imaturos, que não enxergam nada mais do

\footnotetext{
${ }^{224}$ Carta de Marx a Kugelmann, de 23/2/1865 (MARX; ENGELS. Obras escolhidas. São Paulo: Alfa-Omega, v.3, 1980, p.258).

225 Ibid.

${ }^{226}$ Carta de Engels a Conrad Schmidt de 27/10/1890 (Marx; Engels, 1983, p.463-464).

227 Segundo Bo Gustafsson, em 1890 a fração parlamentar era composta por 35 dirigentes, dos quais 7 eram jornalistas; 6 eram comerciantes; 4 eram escritores; 3 eram hoteleiros; 3 eram fabricantes de cigarros; 2 eram aposentados; 2 eram industriais; 2 eram artesãos; 1 era sapateiro; 1 era litógrafo; 1 era editor; 1 era advogado; 1era funcionário do partido e 1 era alfaiate (Gustafsson, 1975, p.31).
} 
que a sua presunção sem limites, querem indicar a tática do partido.

Enquanto o Congresso de Halle centrava-se na discussão a respeito do destino a ser dado ao "Grupo dos Jovens", Viktor Adler manifestou inquietude em relação ao perigo oposto: uma forte tendência de "possibilismo" que desde Nuremberg se fazia notar mais claramente dentro do partido ${ }^{228}$. Os "possibilistas" visavam confrontar a resolução do Congresso de St. Gall, em 1887, em que ficou estabelecido que os socialistas se absteriam de votar nos segundos turnos onde seus representantes não estivessem na disputa. Apesar da desconfiança de líderes do partido, em 1890, foi aprovada uma nova resolução que instruía seus membros a votarem a favor de candidatos que se comprometessem a não restabelecer as leis anti-socialistas.

Não obstante as diversas dificuldades originadas a partir de tal resolução, colocando em relevo a problemática concernente à política de alianças - que se desenvolverá mais abertamente nos Estados do sul do Império - a preocupação com o recrudescimento da repressão governamental mostrou-se legítima. Já em novembro de 1894, o chanceler Chlodwig Karl Viktor zu Hohenlohe-Schillingsfürst cedeu à pressão dos conservadores ${ }^{229} \mathrm{e}$ fez retroceder as medidas liberais adotadas pelo governo, dando início a uma batalha contra os partidos revolucionários (Umsturzparteien).

A perseguição aos social-democratas se deu basicamente por intermédio de um projeto de lei de "combate à subversão" que tornava as greves praticamente impossíveis. Ainda no mesmo ano, o governo revisou a legislação repressiva contra a imprensa (Umsturzvorlage) e tentou passar uma lei de censura artística e literária (Lex Heinze). Diversos líderes da socialdemocracia foram processados e condenados neste período. Entre eles estava Liebknecht, preso em 1895 em razão de um discurso proferido no Congresso do partido.

Tal política de "endurecimento" foi igualmente efetuada nos diferentes Estados. Em 1896 a Saxônia teve a sua legislação eleitoral modificada, enquadrando-se nos moldes do sistema eleitoral prussiano indireto e de três classes, o que ocasionou a perda de 15 dos 16 assentos conquistados pela social-democracia no Estado. A mesma alteração, desta vez a ser implementada a nível federal, foi aventada em proposta de lei encaminhada ao Reichstag, contudo a lei das três classes não chegou a ser aprovada. Tentativas de fazer ressuscitar as leis

\footnotetext{
${ }^{228}$ Gustafsson, 1975, p.28.

${ }^{229}$ A pressão foi exercida principalmente pelos ministros do interior de Hohenlohe, da Prússia - von Köller e Freiherr von der Recke - e pelo ministro de finanças do Reich - Miquel (Rodes, 1964).
} 
anti-socialistas - sob o nome de "Lei contra as pretensões da social-democracia perigosas à comunidade" - no intuito de "suprimir a agitação", também não passaram no Reichstag. Não obstante a sua sanção pelo governo prussiano em 1897, a lei foi declarada inconstitucional pela Corte Suprema da Prússia.

Ainda em 1897 foi proposto ao Reichstag projeto de lei que tornaria ilegal incitar a greve ou se filiar a associações que possam pressionar empregadores. No ano seguinte o Imperador realizou inúmeros discursos em defesa da lei anti-greve,em que exigia duras sentenças de prisão para grevistas, mais conhecidos como "Discursos Penitenciários". Seu objetivo foi atingido em 1899, com a "limitação do direito de greve pela proteção da liberdade do trabalho",230.

As iniciativas visando a retomada da repressão nos anos 90, associadas à criação de inúmeros grupos patronais - como o "Zentralverband der deutschen Industrie" e o "Bund deutscher Industrieller" - estão intimamente relacionadas ao avanço extraordinário do partido. Em sua “Introdução à Luta de Classes na França - 1848-1850”, escrito em 1895, Engels exalta a ação dos social-democratas alemães que graças à inteligência com que fizeram uso do sufrágio universal, instituído em 1866, conseguiram que o "aumento assombroso do partido aparecesse claramente aos olhos do mundo inteiro em cifras indiscutíveis" ${ }^{231}$. Assim, ao encararem o sufrágio como um instrumento em favor da emancipação, ao invés de um mero instrumento de manipulação ou de "fraude governamental", serviriam de modelo aos demais partidos socialistas da Europa ${ }^{232}$ :

O partido alemão - o mais forte, o mais disciplinado e o que crescia mais rapidamente -, além do serviço que prestava, com a sua simples existência, aos operários de todo o mundo, serviu ainda à causa de outra maneira: mostrando aos seus camaradas de todos os países a forma correta de utilizar o sufrágio universal $^{233}$.

\footnotetext{
${ }^{230}$ Cf. Rodes, 1964.

${ }^{231}$ ENGELS. "Friedrich Engels: Política". José Paulo Netto [org]. In: Coleção Grandes Cientistas Sociais, n. 17, São Paulo: Ática, 1981, p.216.

${ }^{232}$ Przeworski apresenta os números do progresso obtido pelos partidos socialistas, a partir da utilização da tática eleitoral: em 1907 os social-democratas finlandeses conseguiram a maioria relativa dos votos, 37\%, na primeira eleição com sufrágio; no mesmo ano os austríacos obtiveram 21\%, em 1911 25,4\% e em 1914 chegaram a 40,8\%; o Parti Ouvrier belga conseguiu 13,2\% de votos em 1894, chegando a 39,4\% em 1925; na Holanda o partido socialista passou de 3\% em 1896 para 18,5\% em 1913; na Dinamarca de 4,9\% em 1884 para 3,5\% em 1889, tendo crescido até chegar a 46,1\% em 1935; na Suécia alcançou 3,5\% em 1902, 9,5\% em 1905, 14,6\% em 1908, 28,5\% em 1911, 30,1\% e 36,4\% em 1914, chegando a 39,1\% em 1917; já na Noruega o Partido Trabalhista cresceu gradualmente, saltando de 0,6\% em 1897 para 32,1\% em 1915 (Przeworski, 1989, p.32-33).

${ }^{233}$ Engels, 1981, p.217.
} 
A apresentação do sufrágio como um "instrumento de emancipação" e de sua conquista como "uma das mais importantes tarefas do proletariado militante", contudo, não deve ser compreendida como a abdicação da luta revolucionária e a adesão irrestrita de Engels à chamada "via pacífica ao socialismo". A utilização estratégica do direito ao voto, seja com vistas à agitação política, propaganda ou autoproteção contra eventuais medidas repressoras, não implicariam, portanto, a renúncia aos objetivos revolucionários:

E se o sufrágio não tivesse outra utilidade que a de permitir que nos contássemos de três em três anos; que a de aumentar, pela ascensão regularmente constatada, a certeza da vitória dos operários na mesma medida que o medo dos adversários, tornando-se assim nosso melhor meio de propaganda; que a de divulgar exatamente a nossa própria força, assim como a dos outros partidos, fornecendo-nos, ainda, para avaliar a nossa ação, um critério superior a qualquer outro, preservando-nos, pois, quer de uma pusilanimidade inoportuna quer de uma audácia aloucada e igualmente inoportuna - se este fosse o único benefício que o sufrágio universal nos proporcionasse, isto já seria mais que suficiente. Mas o sufrágio universal nos deu muito mais. Com a agitação eleitoral, forneceu-nos um meio sem igual para entrar em contato com as massas populares onde elas ainda estão afastadas de nós, para obrigar a todos os outros partidos a defender diante do povo as suas posições e ações frente aos nossos ataques; e, além disto, abriu aos nossos representantes no Reichstag uma tribuna a partir da qual eles puderam falar aos seus adversários no parlamento e às massas no exterior, com uma autoridade e uma liberdade diversas das existentes na imprensa e nos comícios ${ }^{234}$.

Para Engels, o governo e as classes dominantes teriam esgotado todos os meios legais para impedir a expansão da social-democracia, o que significaria que em breve poderiam lançar mão de medidas violentas para a contenção da classe operária. Preocupado com tal perspectiva, Engels advertira que as condições de luta se transformaram profundamente. Neste sentido, a rebelião ao estilo antigo, o combate nas barricadas, estaria ultrapassado. A superioridade das tropas dos exércitos em número, equipamento, organização e disciplina, além da nova conformação das cidades, com largas ruas e avenidas, tornariam inviável uma "revolução de minorias", nos moldes das revoluções de 1848 e 1871. Somente revoluções de maiorias conscientes e preparadas poderiam obter êxito contra os assaltos da reação governamental.

Deste modo, o longo e perseverante trabalho de educação e organização levado a efeito em tempos de "paz" favoreceria o crescimento contínuo das forças socialistas

${ }^{234}$ Engels, 1981, p.218. 
revolucionárias, posto que, em suas palavras, "nós, os 'revolucionários', os 'subversivos', prosperamos muito melhor através dos meios legais do que pelos ilegais e pela subversão. Os partidos da ordem, como eles se autodenominam, desaparecem pelo estado legal que eles mesmos criaram",235.

É importante lembrar que o referido texto de Engels teve uma origem conturbada ${ }^{236}$. A versão original do documento sofreu inicialmente alterações realizadas pelo próprio autor, a pedido de Richard Fischer, editor do Neue Zeit. Em virtude do clima de instabilidade política causado pelo projeto de lei anti-socialista em debate no Reichstag, Engels aceitou, a contragosto, a requisição para suprimir partes do texto que faziam alusão direta à revolução armada. Em resposta a Fischer, Engels expôs sua desaprovação quanto à rejeição a priori da luta armada:

Não posso supor que vocês tenham a intenção de devotar-se de corpo e alma à legalidade absoluta, à legalidade em todas as circunstâncias, à legalidade inclusive em relação a leis violadas pelos que as fizeram, em suma, à política que consiste em oferecer a face esquerda a quem golpeou a direita. Na verdade, nas páginas do Vorwärts, a revolução é renegada algumas vezes com a mesma energia com que era antes - e talvez volte à sê-lo em breve - pregada. Mas certamente, não posso considerar isso como norma. (...) Transformar uma tática momentânea numa tática permanente, uma tática relativa numa tática válida no absoluto: isso eu não farei, nem poderia fazer sem descaracterizar-me irremediavelmente ${ }^{237}$.

Engels manifestou ainda maior irritação quando Liebknecht publicou passagens do texto no jornal do partido, sem o seu consentimento, que lhe deturpavam o sentido. Em carta a Paul Lafargue, Engels recrimina a atitude de Liebknecht e sua postura inflexível em defesa da legalidade a todo custo:

Liebknecht acaba de me pregar uma peça. Tomou, de minha introdução aos artigos de Marx sobre a França em 1848-1850, o que podia servir-lhe para sustentar a tática de paz a qualquer preço que decidiu pregar a algum tempo, sobretudo neste momento em que se preparam leis coercitivas em Berlim. Mas, só recomendo essa tática para a Alemanha de hoje e, ainda assim, com boa reserva. Para a França, a Bélgica, a Itália e a Áustria, essa tática não poderia ser seguida em seu conjunto, e, para a Alemanha, ela poderá tornar-se inaplicável amanhã. Peço-lhe que aguarde o artigo completo antes de julgá-lo (...). É

\footnotetext{
${ }^{235}$ Engels, 1981, p. 224.

${ }^{236}$ Cf. TEXIER, Jacques. Revolução e democracia em Marx e Engels. Rio de Janeiro: UFRJ, 2005, p.155-163.

${ }^{237}$ Carta de Engels a Fischer de 8/3/1895 (Engels, apud Texier, 2005, p.149).
} 
lamentável que Liebknecht só enxergue branco ou preto. As nuanças não existem para ele. ${ }^{238}$

Tanto a versão modificada do artigo na Neue Zeit, quanto as passagens escolhidas a dedo por Liebknecht, publicadas no Vorwärts, causaram grande impacto na socialdemocracia. A partir de então o texto foi comumente utilizado por membros da corrente reformista e adeptos da via pacífica e eleitoral que passaram a elevar o texto de Engels ao status de "testamento teórico". Deste modo, subvertiam por completo o sentido dos argumentos esboçados por Engels - desenvolvidos à luz das condições encontradas na Alemanha em meados da década de 90 - apresentando-os como prova de que Engels, ao final de sua vida, havia revisto seu posicionamento revolucionário e aderido irrestritamente à defesa da legalidade ${ }^{239}$.

Somente em 1925 a versão completa do texto foi publicada por Riazánov, diretor do Instituto Marx e Engels de Moscou. Em 1926, Bernstein publicou duas cartas de Richard Fischer a Engels (de 6/3/1895 e de 14/3/1895) na Sozialistische Monatschefte. Porém, apenas com a publicação da carta-resposta de Engels a Fischer por Hans-Josef Steinberg, em 1967, a crítica de Engels às alterações solicitadas ao seu texto tornaram-se conhecidas.

A despeito destas novas evidências, muitos estudiosos contemporâneos, seguindo os passos de uma longa lista de autores vinculados ao marxismo ocidental ${ }^{240}$, persistem em identificar nas obras do "último Engels" - isto é, seus escritos das décadas de 70, 80 e 90 uma postura reformista de sustentação de uma estratégia "evolucionista-eleitoral" de chegada ao poder. Coadunando-se a tal visão, Hector Benoit ${ }^{241}$ credita a Engels a defesa de uma concepção evolucionista e cientificista, baseada em um sistema naturalista-positivista, que lhe permitiria prever com um "rigor científico inexorável" o curso da natureza e da história. Segundo Benoit, Engels seria responsável por introduzir uma série de deformações ao pensamento original de Marx, consubstanciadas em sua obra inacabada "Dialética da Natureza", escrita entre 1873 e 1882. A concepção naturalista da dialética do último Engels, a

\footnotetext{
${ }^{238}$ Carta de Engels a Paul Lafargue, de 3/4/1895 (Engels, apud Texier, 2005, p.161).

${ }^{239}$ Concordamos com Hans-Josef Steinberg, que afirmara que a introdução de Engels foi mal compreendida: "É um fato que - recorrendo à autoridade de Engels - expoentes de primeiro plano da social-democracia alemã fizeram passar por elemento essencial da tática e da estratégia "marxistas" um apego rígido e irremovível à linha dos sucessos eleitorais, o que falseava completamente a perspectiva de Engels" (Steinberg, 1982, p.218).

${ }^{240}$ Entre os grandes teóricos que endereçaram críticas à concepção dialética formulada por Engels podemos citar Lukács, Korsch, Gramsci, Sartre, Adorno, Marcuse, Goldmann e Colletti (COGGIOLA, O segundo violino. São Paulo: Xamã, 1995, p.76).

${ }^{241}$ BENOIT, Hector. "Da dialética da natureza a derradeira estratégia política de Engels". In: A obra teórica de Marx: atualidade, problemas e interpretações. São Paulo: Xamã, 2000, pp. 91-107.
} 
seu ver, teria conduzido Engels a erros conceituais que se manifestariam igualmente na "dimensão ideológico-política":

Ora, o que representa aparentemente só um erro conceitual ou método lógico insignificante para a luta propriamente política mostra-se posteriormente como o que realmente é: uma perspectiva burguesa de classes, posições senão diretamente traidoras (em relação aos interesses da classe operária) ao menos, objetivistas, não-revolucionárias e reafirmadoras da posição burguesa de dominação $0^{242}$.

Em sentido radicalmente oposto, Oswaldo Coggiola interpreta o fato de Engels conceber a dialética material (o movimento dialético do mundo real) como a base da dialética histórica e da lógica dialética (ciência do pensamento) como sendo algo próprio do ponto de vista do materialismo histórico, uma vez que este não realiza a separação abstrata da natureza e da história como campos regidos por leis diferentes ${ }^{243}$. Com efeito, tanto para Marx como para Engels, a história humana só poderia ser compreendida dentro e como prolongamento da história natural ${ }^{244}$. Contudo, de acordo com seu entendimento, isto não significaria dizer que ocorreria a transposição mecânica da "organicidade natural” para o âmbito da história:

A especificidade da história da sociedade humana é um momento dentro do conjunto das leis que regem o desenvolvimento da realidade natural e social. A principal é a possibilidade, nessa última, da consciência dessas leis, com vistas a governar o futuro desenvolvimento, dentro dos limites impostos pela própria necessidade natural, que determina os limites da própria ação humana ${ }^{245}$.

Assim, de acordo com Coggiola, embora seja possível considerar as incursões de Marx e Engels pelo campo das ciências exatas e naturais como desatualizadas, à luz das inúmeras descobertas científicas subseqüentes, ainda conservariam seu valor metodológico. Outrossim, infere que os autores "não pretendiam revolucionar as ciências da sua época, mas demonstrar que todo o seu desenvolvimento progressivo devia refletir o movimento dialético da realidade" ${ }^{246}$. Nestes termos, a dialética materialista não se fundaria numa arbitrariedade especulativa, isto é, numa tentativa de "fechar" a história do mundo e do conhecimento em um sistema de verdades absolutas, tal como encontrado na filosofia positivista. Ao contrário, em "Ludwig Feuerbach e o fim da filosofia clássica alemã", texto datado de 1886, Engels

\footnotetext{
${ }^{242}$ Benoit, 2000, p.97.

${ }^{243}$ Coggiola, 1995, p.78.

${ }^{244}$ Ibid.

${ }^{245}$ Ibid, p. 79.

${ }^{246}$ Ibid, p. 80.
} 
sublinharia mais uma vez a ruptura do marxismo com a filosofia especulativa, sobretudo a hegeliana, no intuito de redefinir o método dialético como a "ciência das interconexões", que seria, nas palavras de Engels:

o grande pensamento básico de que o mundo não deve ser compreendido como um complexo de coisas já prontas, mas como um complexo de processos, onde o aparentemente estável, assim como a imagem que temos dele, os conceitos, sofrem um processo ininterrupto de vir a ser e deixar de ser, onde, apesar de tudo parecer acidental, há um desenvolvimento fundamental que se impõe no final. ${ }^{247}$

É necessário observar, portanto, que, não obstante seu fascínio pelas novas descobertas científicas e sua tentativa de transpor o método dialético simultaneamente para o domínio da natureza e da história, Engels fazia uma clara distinção, no que concerne à especificidade das leis gerais do movimento aplicáveis à sociedade humana ${ }^{248}$ (lei da passagem da quantidade à qualidade, da interpenetração dos contrários e da negação da negação). Como Engels ressalta no referido texto, a práxis seria a essência humana da história:

A história do desenvolvimento da sociedade difere substancialmente, num ponto, da história do desenvolvimento da natureza. Nesta - se excluímos a reação exercida, por sua vez, pelos homens sobre a natureza - o que existe são fatores inconscientes e cegos que atuam uns sobre os outros e em cuja ação recíproca se impõe a lei geral. (...) Em troca, na história da sociedade, os agentes são todos homens dotados de consciência, que atuam sob o impulso da reflexão ou da paixão, buscando determinados fins; aqui, nada se produz sem intenção consciente, sem um fim desejado. (...) Os homens fazem sua história, quaisquer que sejam os rumos desta (grifo nosso), na medida em que cada um busca seus fins próprios, com a consciência e a vontade do que fazem; e a história é, precisamente, o resultado dessas numerosas vontades projetadas em direções diferentes e de sua múltipla influência sobre o mundo exterior. ${ }^{249}$

Diferentemente da filosofia da história hegeliana - que concebia a história, em conjunto e em suas diversas partes, como "a realização gradual de certas idéias que, naturalmente, eram sempre as idéias favoritas do próprio filósofo" - a história não seria

\footnotetext{
${ }^{247}$ Ibid, p.99.

${ }^{248}$ Cabe lembrar a afirmação de Engels no seu prefácio de 1885 ao "Anti-Dürhing": "Marx e eu fomos, sem dúvida alguma, os únicos que salvaram da filosofia idealista alemã a dialética consciente, incluindo-a na nossa concepção materialista da natureza e da história. Mas uma concepção da história, a um tempo dialética e materialista, exige o conhecimento das matemáticas e das ciências naturais" (ENGELS, Friedrich. Anti-Dühring. Rio de Janeiro: Paz e Terra, 1979, p.10).

${ }^{249}$ MARX; ENGELS. "Ludwig Feuerbach e o fim da filosofia alemã". In: Obras escolhidas, v.3. São Paulo: Alfa-ômega, 1980, p.197-198.
} 
orientada, "sob o império da necessidade, para um objetivo ideal, fixado antecipadamente" 250 . Para Engels, todas as etapas históricas são transitórias, sendo recomendável a superação tanto das categorias metafísicas que encaram os objetos como fixos, acabados e imutáveis, como das "velhas antíteses rígidas" e das "linhas nítidas de demarcação intransponíveis", que postulam soluções objetivas e verdades eternas. Neste sentido, a antítese entre "necessário" e "casual" - assim como os pares "idêntico" e "diferente", "verdadeiro" e "falso" - teria um valor apenas relativo, posto que, "o que se afirma como necessário é feito de toda uma série de simples acasos e o que se acredita casual nada mais é que a forma sob a qual a necessidade se esconde" 251 .

Logo, como foi visto, Engels rejeita uma concepção mecanicista e fatalista da história, ao ressaltar que são os homens que atuam na história, embora estejam interagindo com uma multiplicidade de forças motrizes conscientes ou inconscientes, pois "tudo que põe os homens em movimento tem necessariamente que passar por suas cabeças: mas a forma que adota dentro delas depende muito das circunstâncias" ${ }^{252}$. Da mesma forma que as leis gerais do movimento, imanentes e ocultas ${ }^{253}$, se impõem como dominantes na história humana, os fenômenos naturais também estariam em processo de incessante transformação, evidenciando, assim, o caráter histórico da natureza ${ }^{254}$.

Sendo evidente a preocupação de Engels em assumir uma postura anti-dogmática, através da dissociação entre o método e o sistema hegeliano, haveria fundamento atribuir a ele a responsabilidade pela propagação de uma versão vulgarizada da dialética materialista? $\mathrm{Ou}$ seja, seria correto entrever na tentativa engelsiana de congregar em outro patamar sistema e método, prescindindo por completo de uma "filosofia superior" dedicada especialmente ao estabelecimento de concatenações universais, uma abertura teórica que tornaria admissível uma concepção evolucionista e determinista da história, disseminada entre os membros do partido - principalmente devido à influência de dirigentes como Kautsky, Bebel e Liebknecht -, que, por sua vez conduziria as massas ao imobilismo e à passividade?

\footnotetext{
${ }^{250}$ Ibid, p. 197.

${ }^{251}$ Ibid, p. 195.

${ }^{252}$ Ibid, p. 199.

${ }^{253}$ Estas leis seriam alcançadas através da conexão real a ser verificada nos próprios fatos, e não por outra lei “inventada pelo cérebro do filósofo" (Engels, 1980, p.197).

${ }^{254}$ Como Engels esclarece no prefácio ao "Anti-Dühring", de 23 de setembro de 1885, "Reconhecer que estes contrastes e diferenciações se encontram sem dúvida na natureza, mas relativamente apenas, que esta rigidez pressuposta, este valor absoluto não se enquadram na natureza senão pela nossa reflexão; eis em que consiste, na essência, a concepção dialética da natureza.” (Engels, 1979, p.13).
} 
De acordo com Ricardo Musse ${ }^{255}$, a exposição formal da dialética, realizada através de textos como o "Anti-Dühring" - escrito em 1878 como resposta à filosofia eclética difundida pelo professor Eugene Dühring - teve como conseqüência a transformação do marxismo em um sistema orientado para a compreensão geral do homem e da natureza. A utilização do método uniforme - composto por um conjunto de leis gerais necessárias ao conhecimento positivo e real do mundo - no intuito de atualizar a teoria de acordo com as exigências decorrentes de mudanças históricas conjunturais, incluindo a expansão dos limites do marxismo para outros domínios (como a crítica à filosofia da natureza, as teorias acerca da violência, a moral, o direito, etc.), teria levado Engels a ordenar a teoria em um conjunto sistemático, enciclopédico.

Desta maneira, não obstante sua crítica à elaboração de sistemas filosóficos ${ }^{256}$, o esforço de contestação do "sistema filosófico integral” de Dühring teria contribuído para que,

à revelia da intenção do autor, o Anti-Dühring e, por extensão, o próprio marxismo, então em processo de delimitação enquanto escola distinta das demais correntes socialistas, fosse tomado, no mesmo registro das disciplinas burguesas rivais e na acepção própria da época, como um sistema, isto é, como uma teoria unitária do homem e da natureza ${ }^{257}$.

Assim, Musse observa que, como principal sistematizador, intérprete e divulgador do marxismo, Engels procedeu a uma esquematização e síntese da teoria, cuja apropriação pelos líderes do SPD - especialmente através da versão condensada do "Anti-Dühring" publicada em 1880, sob o título "Do socialismo utópico ao socialismo científico" - ganhou contornos particulares, com infiltrações positivistas, mecanicistas, deterministas e historicistas. Com efeito, "a adesão dessa nova versão à autocompreensão do marxismo como "socialismo científico", destacada reiteradamente pelos teóricos da social-democracia, suscitou por longo tempo uma impressão de identidade ou mesmo de inextrincabilidade entre as doutrinas de Engels e da Segunda Internacional”. Tal adesão é confirmada igualmente por David Razanóv:

É preciso reconhecer que, para a difusão do marxismo como método e sistema especial, nenhum livro depois de O Capital fez tanto como $O$ Anti-Dühring. Todos os jovens marxistas -

\footnotetext{
${ }^{255}$ MUSSE, Ricardo. "De Friedrich Engels a Rosa Luxemburg". Do socialismo científico à teoria crítica: modificações na autocompreensão do marxismo entre 1878 e 1937. São Paulo: USP/FFLCH [Tese], 1998, cap.III.

${ }^{256}$ Engels ressalta em "Ludwig Feuerbach e o fim da filosofia alemã": "o sistema representa, precisamente, o que é efêmero em todos os filósofos, e o é, justamente, porque brota de uma perene necessidade do espírito humano: a necessidade de superar todas as contradições" (Engels, 1980, p.175) .

${ }^{257}$ Musse, 1998, cap.III.
} 
Bernstein, Kautsky, Plekhánov - que travaram suas primeiras lutas entre 1880 e 1885 aprenderam no livro de Engels. ${ }^{258}$

É importante, portanto, distinguir o pensamento de Engels daquele formulado pela geração subsequiente de socialistas, ainda que esta tenha sofrido forte influência de seus escritos. Neste sentido, atribuir ao autor uma adesão ao determinismo econômico ${ }^{259}$ e ao positivismo, concepções que o próprio Engels não cessou de combater, seria tão equivocado quanto lhe conferir o papel de campeão da legalidade e de crítico das revoluções violentas. Como salientara Rosa Luxemburg:

Quando se conhece as obras de Marx e Engels, quando se conhece o espírito revolucionário vivo, autêntico, inalterado, que se desprende de todos os seus escritos, de todos os seus ensinamentos, ficamos convencidos de que Engels teria sido o primeiro a protestar contra os excessos que resultaram do parlamentarismo puro e simples $(. . .)^{260}$.

A defesa de Engels da legalidade "até quando for conveniente", portanto, não deve conduzir a enganos ou conclusões apressadas. Trata-se de evitar o confronto até o momento decisivo, de modo que se possa resistir à ilegalidade da contra-revolução "de armas em punho" "261 . Como Engels afirma em carta a Paul Lafargue, "todo apelo à legalidade tem como única finalidade manter preparado o núcleo principal do movimento operário internacional para o momento crítico, evitando que ele se desgaste em batalhas precipitadas"262. Deste modo, como convenientemente salientou Jacques Texier,

sem dúvida, Marx e Engels admitiram constantemente uma transição pacífica ao socialismo em certo número de países, principalmente na Inglaterra, (...) mas o certo é que, nem em 1895, nem em 1891, nem em 1875, Marx e Engels visualizaram uma transição pacífica no país de Bismarck, nem ao socialismo, nem à democracia. ${ }^{263}$

\footnotetext{
${ }^{258}$ RIAZANOV, David. Marx - Engels e a história do movimento operário. São Paulo: global, 1984, p.180.

${ }^{259}$ Em carta a Bloch, de 21/9/1890, Engels assinala sua contraposição em relação ao determinismo econômico que lhe tentavam imputar: "De acordo com a concepção materialista da história, o elemento finalmente determinante é a produção e a reprodução da vida real. Nem Marx nem eu asseveramos mais do que isso. Logo, se alguém torce isso, dizendo que o elemento econômico é o único determinante, ele transforma aquela proposição em uma frase sem sentido, abstrata e tola" (Marx; Engels, 1983, p.132).

${ }^{260}$ LUXEMBURG, Rosa. "O nosso programa e a situação política”. In : Reforma social ou Revolução? E outros textos. Lisboa: Escorpião, [197-], p.111.

${ }^{261}$ Em carta a Laura Lafargue, de 14/3/1890, Engels ressalta: "Conhecemos tempos agitados e tudo dependerá da aptidão de nossos amigos a não se deixarem arrastar a tumultos por meio de provocações. Dentro de três anos, teremos talvez os trabalhadores agrícolas, o elemento decisivo na Prússia, e então...fogo!" (Texier, 2005, p.155).

${ }^{262}$ Carta de Engels a Paul Lafargue de fevereiro de 1895 (Steinberg, 1982, p.217).

${ }^{263}$ TEXIER, Jacques. Revolução e democracia em Marx e Engels. Rio de Janeiro: UFRJ, 2005, p.109.
} 
Logo, a utilização do sufrágio não substituiria de forma necessária e absoluta o emprego de outras táticas para se alcançar o fim revolucionário ${ }^{264}$. A escolha dos meios a serem usados variaria de acordo com as condições encontradas em determinado lugar e momento histórico, das forças sociais em conflito e das armas a disposição da classe operária para a conquista do poder. Conforme Hobsbawm exprimira, "a forma assumida pela efetiva transferência do poder e, portanto, a transformação subseqüente da sociedade dependeriam do grau de desenvolvimento alcançado pelo proletariado e por seu movimento, que refletiam, por seu turno, tanto o grau de desenvolvimento do capitalismo, quanto o seu próprio processo de aculturação e de maturação através da práxis"265.

Já em sua "Crítica ao Projeto de Programa Social-Democrata", de 1891, Engels ressaltava que a social-democracia deveria defender todas as reivindicações que pudessem a aproximar do objetivo revolucionário - sendo as reivindicações políticas vistas simplesmente como apenas mais um meio para alcançar a reivindicação principal ${ }^{266}$. Todavia, o autor alertava para o perigo de se resvalar no mesmo oportunismo disseminado por parte da imprensa social-democrata que, com medo de uma renovação das leis contra os socialistas, apresentava a preservação da ordem legal na Alemanha como elemento suficiente para garantir a realização de todas as suas reivindicações pela via pacífica ${ }^{267}$. Deste modo, levariam o partido, e a si próprios, a acreditar que a sociedade atual, ao desenvolver-se, passaria pouco a pouco para o socialismo ${ }^{268}$.

Segundo Engels, a "ilusão da via legal" promoveria o "esquecimento das grandes considerações essenciais perante os interesses passageiros do dia, esta corrida aos sucessos efêmeros e a luta que se trava em torno deles sem ter em atenção as conseqüências ulteriores,

\footnotetext{
${ }^{264}$ Confira a carta de Engels a Paul Lafargue de 12/11/1892: "Vejam agora que arma esplêndida teremos entre as mãos na França, há quarenta anos, com o sufrágio universal, se tivéssemos sabido utilizá-lo! É mais lento e mais enfadonho do que o apelo à revolução, mas é dez vezes mais seguro e, o que vale mais ainda, indica com a mais irrepreensível exatidão o dia em que será necessário chamar à revolução pelas armas" (Texier, 2005, p.155); e de $12 / 2 / 1892$, na qual afirma que o valor do sufrágio consiste em que "mostra com toda a exatidão o dia em que se deverá lançar mão das armas para fazer a revolução; há inclusive dez probabilidades contra uma de que se os trabalhadores utilizam com habilidade o sufrágio universal, os grupos dominantes se verão forçados a transgredir a legalidade, isto é, colocar-nos na posição mais favorável para levar adiante a revolução" (Gustafsson, 1975, p. 100).

${ }^{265}$ HOBSBAWM. “Aspectos políticos de transição do capitalismo ao socialismo”. In: História do marxismo I: o marxismo no tempo de Marx. Rio de Janeiro: Paz e Terra, 1987, p.318.

${ }^{266}$ MARX, Karl; ENGELS, F; LENIN, V. I. Critica do Programa de Gotha, Critica do Programa de Erfurt e Marxismo e Revisionismo. Porto: Portucalense, 1971, p.46.

${ }^{267}$ A transição pacífica é concebida nos países em que a representação popular concentra em si todo o poder, repúblicas democráticas como a França e a América e monarquias como a Inglaterra (cf. Engels, 1971, p.47).

${ }^{268}$ Ibid, p.47.
} 
este abandono do futuro do movimento que se sacrifica ao presente"269. Desta maneira, Engels encara o reformismo presente entre setores do partido, como o "tipo de política que arrastará o partido para um caminho falso" 270 , pois:

o fato de que na Alemanha, nem sequer ser permitido formular um programa de partido abertamente republicano prova bem como é enorme a ilusão de que será possível organizar a república, por uma via tranquiilamente pacífica, e não só a república mas ainda a sociedade comunista ${ }^{271}$.

A preocupação de Engels em relação à possível repressão do governo não era desmedida. Mesmo Bakunin, defensor da estratégia de guerrilhas, insurreições locais e da sublevação espontânea das massas populares, reconheceu, em 1873, o poderio do exército alemão $^{272}$ e a influência exercida pelo "espírito militarista"273 sobre a população - que considerava igualmente uma ameaça à mobilização dos trabalhadores pelo fato de penetrar as associações operárias, disseminando a exaltação à disciplina e o respeito à ordem e à autoridade. Em seu livro "Anarquismo e estatismo", Bakunin analisou os efeitos deste aspecto, que considerava constitutivo do caráter do povo alemão ${ }^{274}$. Assim, observara que o "servilismo", a "submissão", a "obediência" e o "culto à autoridade" sobrepunham-se à ânsia do povo por liberdade.

Ademais, tal mentalidade manifestar-se-ia em toda a sua força na forma de um corpo militar com profundo desprezo e antipatia em relação aos revolucionários social-democratas. A descrição que Bakunin oferece dos membros do exército alemão como inimigos sistemáticos das massas populares, caracterizados por uma arrogância junker que alia a cultura à barbárie e o saber ao servilismo em relação ao Estado ${ }^{275}$, pode servir inclusive como base para a compreensão dos desdobramentos históricos nas primeiras décadas do século XX e a ampla adesão ao nazismo dentro das forças armadas.

\footnotetext{
${ }^{269}$ Ibid, p.48.

${ }^{270}$ Ibid, p.47.

${ }^{271}$ Ibid, p.48.

${ }^{272}$ Em sua análise Bakunin descreve o exército alemão como o "exército real de um milhão de homens, que sob o aspecto da organização, da instrução, da arte militar, da moral e do armamento, é o primeiro do mundo" (Bakunin, p.2003,109).

${ }^{273}$ Em artigo de 12/2/1865, Engels analisa o "verdadeiro espírito militar", que seria inculcado desde a escola de cadetes (ENGELS, "The Prussian military question and the German Worker's Party". In: www.marxists.org.).

${ }^{274}$ BAKUNIN, Mikhail. Estatismo e anarquia. São Paulo: Editora Imaginário, 2003.

275 "Os militares alemães possuem sobre os militares franceses, e mesmo sobre os outros militares da Europa, uma imensa vantagem; os oficiais alemães superam todos os oficiais do mundo pela seriedade e pela amplitude de seu saber, pelo conhecimento teórico e prático da arte militar, por seu apego apaixonado e meticuloso pela profissão das armas, pela exatidão, pelo método, pelo controle de si, pela paciência incansável, tanto quanto pelo grau de probidade" (Bakunin, 2003, p.109).
} 
Para um exército regular, é, com efeito, difícil imaginar algo de melhor do que o oficial alemão. Trata-se de um ser que alia em si o saber ao servilismo, o servilismo à bravura e a mais rigorosa disciplina à capacidade de iniciativa, o método à crueldade, a crueldade a um tipo de retidão, uma certa exaltação, é verdade, em sentido único se não no mau sentido, a uma submissão, raro igualada, à vontade do chefe; de um ser sempre capaz de degolar ou massacrar dezenas, centenas, milhares de indivíduos ao menor sinal daqueles que o comandam; calmo, discreto, sereno, dócil, sempre em sentido diante de seus superiores, altivo, friamente desdenhoso e, se necessário, cruel em relação ao soldado; um ser cuja vida se exprime em duas palavras: obedecer e comandar; este tipo de homem não tem igual para o exército e para o Estado ${ }^{276}$.

A dura repressão governamental sobre os socialistas, no entanto, não conseguiu barrar o crescimento do partido. O aperfeiçoamento da organização partidária levou o SPD a expandir suas funções, proporcionando a seus membros atividades culturais, educativas e recreativas, bem como acesso a jornais, periódicos e revistas teóricas. Assim, erigia-se todo um "estilo de vida" baseado nos princípios defendidos pelo partido ${ }^{277}$, de modo que este se tornava "não apenas uma máquina de combate político, mas uma micro-sociedade"278 com uma "subcultura" própria ${ }^{279}$, que contava com uma eficiente imprensa, bibliotecas, congressos e conferências públicas, além de desenvolver atividades educacionais.

A adesão ao partido representava, assim, o estabelecimento de laços sociais e redes de apoio mútuo, reafirmando a identidade de classe e o sentimento de pertencimento a um grupo $^{280}$. Jacques Droz ressalta este relevante aspecto da vida partidária:

A extraordinária rede de agrupamentos, associações, sociedades, uniões, comitês, comissões, cooperativas, sedes de sindicatos (...) faziam que um socialista alemão - operário, mulher, jovem, velho, aposentado, doente, desempregado, intelectual - vivesse sua vida, se alimentasse, morasse, se

\footnotetext{
${ }^{276}$ Bakunin, 2003, p.107.

277 Joll, 1976, p.100.

${ }^{278}$ Droz, 1974, p.567.

279 A experiência da vida diária, como nos mostra Geoff Eley, seria indispensável para a construção da identidade coletiva: "Em geral, a vida diária dos trabalhadores revelava muitas pequenas solidariedades. No local, as brincadeiras rudes e a forma agradável de passar o tempo, as brincadeiras ritualizadas e o escárnio mútuo, além dos pequenos roubos e sabotagens, eram tão vitais para o desenvolvimento de culturas de chão-defábrica quanto os sindicatos" (Eley, 2000, p.110).

${ }^{280}$ Convém salientar que dentro do partido constituíram-se variados grupos, como o de mulheres e o da juventude, além de grupos desportivos (como organizações nacionais de Atletas Trabalhadores, Saúde Popular, Ginastas Trabalhadores, Ciclistas Trabalhadores, Nadadores Trabalhadores), artísticos e literários (Cantores Trabalhadores, União Teatral, Livre-pensadores Proletários), ecológicos (Amantes da Natureza) e de ajuda mútua (Samaritanos Trabalhadores, União de Temperança dos Trabalhadores) (Eley, 2000, p.109).
} 
vestisse, lesse, cantasse, praticasse esportes, fosse ao cinema, (...) sem jamais deixar o horizonte socialista ${ }^{281}$.

Para alargar seu escopo e desempenhar funções não apenas políticas, mas econômicas, sociais e culturais, o partido necessitou construir um aparelho burocrático amplo e eficiente, capaz de atuar inclusive nos períodos entre as eleições. Em uma entrevista concedida ao Daily Chronicle, em junho de 1893, Engels prezou a disciplina organizacional do partido:

Nossa organização é perfeita - a admiração e desespero de nossos oponentes. Ela se tornou perfeita graças às leis antisocialistas de Bismarck (...) nosso treinamento militar e disciplina são inestimáveis. Todos os 240.000 eleitores de Hamburg receberam nossos comunicados e literatura em cima da hora. De fato, ano passado o governo desta cidade solicitou que o ajudássemos a distribuir instruções que ensinavam como lidar com a cólera ${ }^{282}$.

A manutenção de um forte e sólido aparelho burocrático - composto por centenas de funcionários permanentes - exigia, todavia, o aumento na arrecadação das contribuições destinadas ao partido e o incremento do número de membros filiados. Com isto, muitos funcionários e dirigentes voltaram sua total atenção para as vitórias eleitorais ${ }^{283}$. Conseqüentemente, como observa Przeworski, "a democracia representativa, para os socialdemocratas, tornou-se simultaneamente o meio e o objetivo, o veículo para o socialismo e a

${ }^{281}$ Droz, 1974, p.567.

282 "Nós não somos o mais forte partido depois do Centro, nós somos de longe mais fortes do que o Centro, quando se trata do corpo eleitoral. A eleição de 16 de junho deste ano nos deu 2.125.000 votos, enquanto o Centro teve apenas 1.333.000 (...). Nós somos um partido em crescimento e expansão, e o Centro é um partido em retração e decadência. (...) o Centro tem quase o dobro de deputados no Reichstag, e mais do que qualquer outro partido. Mas isto é efeito de nosso miserável sistema eleitoral que não proporciona igualdade dos distritos eleitorais. Originalmente, pela "Constituição", nós deveríamos ter um deputado ou membro para cada 100.000 habitantes. Os distritos foram formados no ano de 1867 - ou seja, há trinta e um anos atrás, naquela época, sob a base de um censo de dez anos de idade. Agora imagine a imensa mudança na população e sua distribuição e a grande massa que migrou do campo para as cidades. Naquela época, Berlim tinha 600.000 habitantes, e possuía 6 membros. Agora Berlim tem 1.800.000 habitantes e deveria ter 18 membros. (...) Por outro lado, o número da população no campo permaneceu estacionário ou mesmo diminuiu, e justamente nestas partes onde idéias democráticas e socialistas não encontram tanto respaldo e não consegue se expandir com a velocidade que acontece nas cidades, o Centro e os Conservadores têm o sua maior força e apoio. Se nós tivéssemos tantos membros como nossos votos nos dão direito, nós deveríamos ter 116 membros ao invés de 56, e o Centro Católico cerca de 70, ao invés de 103". (LIEBKNECHT. "A Social-democracia na Alemanha”. In: www.marxists.org ).

${ }^{283}$ Em artigo de 16 de julho de 1898, Liebknecht anuncia: "As vitórias não são ganhas nos campos de batalha; as batalhas são na maioria dos casos ganhas e perdidas antes da briga começar. Nossa organização é tal que nós estamos sempre ordenados e organizados para a luta. Nossos candidatos foram fixados há muito tempo, e nós temos tantos candidatos quanto são os distritos eleitorais no Império Germânico, ou seja 397. (...) Nosso manifesto aos eleitores foi publicado no último domingo. Todos os outros partidos estão ficando para trás. Nós somos o único partido na Alemanha que possui um programa. Nenhum dos outros partidos sabe o que fazer, nenhum se atreve a dizer seus eleitores a verdade, desvelar seus reais objetivos" (Liebknecht, $<$ www.marxists.org $>$ ). 
forma da futura sociedade socialista, a estratégia e o programa, apresentando um caráter ao mesmo tempo instrumental e prefigurativo" ${ }^{284}$.

Liebknecht demonstra tal tendência em artigo intitulado "A social-democracia na Alemanha”, de 16 de julho de 1898, no qual apresentou os resultados eleitorais para o Reichstag referente à eleição daquele ano ${ }^{285}$. Neste, ao mesmo tempo em que enfatizava o progresso atingido pelo partido, o autor sublinhava a necessidade de ampliação da composição social ${ }^{286}$ da social-democracia tendo em vista a defasagem do censo populacional, que conferiria maior peso aos distritos rurais em detrimento das regiões industriais - onde os social-democratas concentrariam sua base eleitoral ${ }^{287}$.

O direcionamento político à constituição de uma base social mais ampla e heterogênea que incluísse a pequena burguesia e os camponeses - a Mittleklass Strategie - produziria, contudo, novas dificuldades. $\mathrm{O}$ apelo às classes médias ocasionaria a perda ou diluição da identidade de classe do partido. Assim, como Przeworski oportunamente apontou,

Ao estender seu apelo às "massas", os social-democratas enfraquecem a importância geral da classe como determinante do comportamento político dos indivíduos. (...) É o próprio princípio do conflito de classes - o conflito entre coletividades internamente coesas - que se torna comprometido quando partidos de operários transformam-se em partidos das $\operatorname{massas}^{288}$.

De acordo com o autor, o sistema democrático teria pregado uma peça perversa às intenções socialistas: a emancipação da classe operária não poderia ser tarefa exclusiva dos próprios operários se tivesse de ser alcançada por intermédio de eleições. Sendo assim, restaria somente a questão de ser ou não possível recrutar uma maioria favorável ao socialismo procurando apoio eleitoral fora do operariado ${ }^{289}$.

Contudo, conforme Engels havia observado, no campo, predominava entre camponeses e trabalhadores rurais a apatia política e o isolamento, além de grande desconfiança em relação aos socialistas, "defensores da partilha". O "instinto de propriedade" do camponês, portanto, repeliria-o à propaganda socialista, uma vez que, "quanto mais difícil

\footnotetext{
${ }^{284}$ Przeworski, 1989, p.29.

${ }^{285}$ Confira o mapa (figura 2 em anexo) publicado juntamente com o artigo de Liebknecht de 16 de julho de 1898: "A Social-democracia na Alemanha" (www.marxists.org).

${ }^{286} \mathrm{O}$ eleitorado maior encontrava-se em cidades de maioria protestante onde a descristianização era particularmente avançada - como Berlim, Hamburgo, Bremen e Lübeck (ibid.).

${ }^{287}$ Segundo Droz (1974, p.36), em 1912 os social-democratas detinham 49,3\% dos votos nas grandes cidades, $35,8 \%$ nas pequenas cidades e $19 \%$ no campo.

${ }^{288}$ Przeworski, 1989, p.41-42.

${ }^{289}$ Ibid, p.39.
} 
se torna a luta por seu pedaço de terra ameaçado, tanto mais violento é o desespero com que se aferra a ele; tanto mais tende a ver, no social-democrata que fala da entrega da terra à coletividade, um inimigo tão perigoso quanto o usurário e o advogado" ${ }^{290}$. Por conseguinte, o camponês tenderia a recorrer ao grande proprietário de terras em busca da defesa de seus interesses. Sendo assim, "o grande latifundiário arvora-se em campeão dos interesses do pequeno lavrador - e este, em termos gerais, aceita-o como tal" ${ }^{291}$.

A atração da pequena-burguesia do campo e da cidade com vistas à vitória eleitoral demandaria, portanto, a moderação do discurso e a ênfase na satisfação de reivindicações imediatas. Com efeito, as alianças e coalizões destinadas a conquistar o voto da pequenaburguesia e da burguesia liberal geraram um dilema não apenas tático, mas uma profunda revisão nos princípios assumidos pela social-democracia. Colocou-se em xeque a própria meta revolucionária, substituindo-a pela conformação aos limites impostos pelo jogo parlamentarista e pela adequação à sociedade burguesa. Deste modo, como destacou Przeworski, embora a participação na política eleitoral tenha se mostrado útil, e até certo ponto necessária, para a transformação dos partidos socialistas em partidos de massas, essa mesma participação parece haver obstruído a consecução de seus objetivos finais. Neste sentido, "trabalhar para o presente ou para o futuro" tornou-se um "verdadeiro dilema" 292.

Desta maneira, a social-democracia alemã viu surgir em seu cerne o estabelecimento da dicotomia entre reforma e revolução. $O$ trabalho cotidiano do partido não seria orientado pelo objetivo revolucionário, que, por sua vez, remanesceria como uma mera representação ideal, quase abstrata, capaz de impulsionar o movimento operário por oferecer-lhe a certeza da vitória final. Assim, consoante a explicação de Hans-Josef Steinberg:

No período de prosperidade econômica, os aspectos de crise do desenvolvimento econômico haviam passado inteiramente para segundo plano enquanto indícios do colapso iminente da sociedade capitalista-burguesa; o lugar deles havia sido tomado - enquanto critério de aferição da velocidade e da direção do desenvolvimento - pelo progressivo aumento dos votos socialdemocratas. Em outras palavras: o expectativismo revolucionário da ortodoxia marxista liderada por Kautsky e Bebel concentrava-se agora - após se ter orientado, até quase o

\footnotetext{
${ }^{290}$ MARX, K, ENGELS, F. “O problema camponês na França e na Alemanha”. In Obras escolhidas. São Paulo: Alfa-Omega, v.2, 1980b, p. 228. Escrito em novembro de 1894, publicado na revista Neue Zeit.

${ }^{291}$ Ibid, p.226. Diante disto, na opinião de Engels, a conquista dos proletários agrícolas da zona Leste do Elba teriam uma maior importância do que a conquista dos pequenos camponeses do ocidente da Alemanha e dos médios camponeses do sul. Precisamente na parte oriental do Elba encontrar-se-ia o "campo de batalha decisivo" envolvendo a conquista dos trabalhadores assalariados rurais (Ibid, p. 242,243).

${ }^{292}$ Pzerworski, 1989, p.26.
} 
final dos anos 90, no sentido da perspectiva do "zás-trás" - na obtenção de novos sucessos eleitorais, os quais, dada a estrutura interna do Reich alemão, tinham necessariamente de restar, em última instância, como algo carente de efeito ${ }^{293}$.

O socialismo, sob este novo prisma, não mais seria concebido como o resultado de um processo revolucionário, conformado pela práxis humana em suas inter-relações recíprocas com uma série de fatores e forças históricas em conflito na sociedade burguesa, mas sim o ponto culminante de uma série ordenada de evoluções sociais que encarnariam a realização do progresso.

Conforme foi apresentado, a participação eleitoral conduziu à reorientação teórica e prática do partido e à adoção de um "radicalismo passivo",294, que enxergava a revolução como uma medida "meramente defensiva, destinada a salvaguardar o exercício do poder legitimamente adquirido pelo voto" ${ }^{, 295}$. Embora houvesse ainda muitos obstáculos a serem removidos para que os socialistas conquistassem a hegemonia política na Alemanha, o sucesso do movimento social-democrata alemão, atingido pela via pacífica e eleitoral, era visto como certo e inexorável.

O crescimento dos partidos de massa social-democratas, seu êxito parlamentar e as reformas sociais, portanto, fizeram com que uma grande parte dos líderes do partido entendesse seu trabalho em termos de consecução de vantagens imediatas para a classe trabalhadora, perdendo de vista a perspectiva de uma decisiva batalha final. Neste sentido "a evolução em direção ao reformismo" não mais estaria ligada à política social do Reich - como anteviam os lassalleanos -, mas às novas possibilidades que seriam proporcionadas aos socialistas nas eleições ${ }^{296}$. A partir de então, inicia-se um distanciamento entre as duas correntes da social-democracia: a revolucionária e a reformista, ambas representadas no novo programa do partido, aprovado em 1891, que veio a substituir o Programa de Gotha - o Programa de Erfurt.

\footnotetext{
${ }^{293}$ Steinberg, 1982, p.218.

${ }^{294}$ Expressão de Pannekoek (Texier, 2005, p.162).

${ }^{295}$ Bebel, 1905, apud, Przeworski, 1989, p.22.

${ }^{296}$ Droz, 1974, p.39.
} 


\section{3- O caráter conciliatório do Programa de Erfurt}

Em meio às discussões acerca do perfil a ser assumido pelo novo programa do Partido Social-Democrata, Engels solicitou à Neue Zeit a publicação da "Crítica ao Programa de Gotha", por considerar como sua obrigação moral ${ }^{297}$ acautelar os membros do partido contra o possível predomínio de uma mentalidade pequeno-burguesa. Através da divulgação da carta escrita por Marx em 1875, Engels esperava que o Congresso de Erfurt adotasse uma postura crítica em relação aos herdeiros de Lassalle e, assim, não voltasse a repetir os erros cometidos em Gotha.

No entanto, como o próprio Engels havia previsto ${ }^{298}$, a direção do partido manifestou profundo desagrado com a contundente crítica ao lassalleanismo desenvolvida no texto, temendo que esta trouxesse graves conseqüências internas para o partido, culminando ulteriormente em sua fragmentação. A despeito das tentativas de obstar a impressão do artigo (ou de ao menos lhe censurar as partes "mais prejudiciais") e da ameaça de intervenção que pairava sobre a revista, lançada pelo grupo parlamentar por intermédio de Dietz - editor do partido -, o texto foi publicado em sua íntegra em 31 de janeiro de 1891.

As críticas, contudo, não tardaram a surgir. Em 13 de fevereiro de 1891, o jornal Vorwärts exprimiu a posição oficial da direção do partido a respeito da "Crítica ao Programa de Gotha", pronunciando-se francamente em oposição às afirmações de Marx. No mesmo mês, Karl Kautsky publicou na Neue Zeit artigo intitulado "Os nossos programas" em que partia em defesa de Lassalle:

A atitude tomada por Marx em relação a Lassalle é diferente da atitude da social-democracia alemã (...) cuja apreciação sobre Lassalle não é a de Marx (...). Poderíamos alguma vez esquecer um homem cujas obras - para nós, velhos membros do partido, e também para a imensa maioria dos jovens membros guiaram os nossos primeiros passos no estudo do socialismo? Nós lemos atentamente e meditamos em tudo o que Marx disse do seu aluno Lassalle, mas não devemos esquecer que Lassalle foi também um dos nossos melhores combatentes ${ }^{299}$.

\footnotetext{
${ }^{297}$ Cf. Carta de Engels à Kautsky, de 23/2/1891 (Marx, Engels, Lênin, 1971, p.81).

${ }^{298}$ Em carta dirigida a Kautsky, escrita em 15/1/1891, Engels afirma: "Liebknecht, que tinha utilizado passagens do manuscrito (Crítica ao Programa de Gotha) - o seu discurso de Halle sobre o programa do partido está aí para o provar - teria movido o céu e a terra para impedir a impressão" (Marx, Engels, Lênin, 1971, p.80).

${ }^{299}$ Marx, Engels, Lênin, 1971, p. 111.
} 
Apesar das objeções opostas ao texto de Marx, Kautsky, sob a orientação de Engels ${ }^{300}$, passou a concentrar esforços para elaborar um esboço de programa a ser apresentado e submetido à votação no Congresso de Erfurt, em substituição ao projeto formulado pelo Comitê Diretor do partido, escrito por Liebknecht.

Ao redigir a parte teórica do Programa de Erfurt, Kautsky procurou adequá-la à teoria marxista. Em seu prefácio à edição alemã de "O Programa Socialista",301, escrito em junho de 1892, Kautsky torna explícita sua filiação teórica:

Afora as curtas brochuras que chamam atenção das massas sobre nossos esforços, nós precisávamos de uma espécie de catecismo da democracia socialista, destinado àqueles que queiram se familiarizar com as idéias socialistas, de um guia para o propagandista que deve ser iniciado. (...) Se eles leram e compreenderam o "Capital", de Marx, os escritos de Engels sobre "A situação da classe operária na Inglaterra", o "Socialismo utópico e o socialismo científico", "A origem da propriedade privada e do Estado", depois "A mulher e o socialismo", de Bebel, e enfim o "Manifesto comunista", que já havíamos citado e que, como um fio condutor (grifo nosso), atravessa todas as obras e as inspira, já são certamente capazes apreender, o conjunto das idéias socialistas modernas ${ }^{302}$.

O programa, portanto, abordava questões centrais do marxismo, como o desaparecimento da pequena indústria, o depauperamento do proletariado, a concentração do capital, o crescente número de proletários e a expansão do exército industrial de reserva, as crises econômicas de superprodução, a ênfase na luta de classes e a crítica ao socialismo de Estado e ao cooperativismo ${ }^{303}$. De acordo com o programa, a monopolização dos meios de produção suscitaria o aumento progressivo da miséria, da opressão, da sujeição, da humilhação e da exploração do proletariado e das camadas intermediárias - pequenos burgueses e camponeses.

\footnotetext{
${ }^{300}$ Em carta a Sorge, de 24/10/1891, Engels manifesta sua aprovação em relação à adoção de uma nova linha teórica pelo partido: "O projeto de Programa defendido por Kautsky, por Bebel e por mim serviu de base à parte política do programa. Tivemos a satisfação de ver a crítica marxista do programa triunfar completamente" (MARX, Karl; ENGELS, F; LENIN, V. I. Critica do Programa de Gotha, Critica do Programa de Erfurt e Marxismo e Revisionismo. Porto: Portucalense, 1971, p.103).

${ }^{301}$ Esta obra foi publicada na Neue Zeit como uma exposição de motivos para o projeto do Programa de Erfurt, em 1891.

302 KAUTSKY, Karl. Le programme socialiste. Paris: Librairie des sciences politiques et sociales Marcel Rivière, 1927, p.1.

${ }^{303}$ A proletarização das massas populares, a reunião de todo o capital entre as mãos de um pequeno número de indivíduos que governam a vida econômica das nações capitalistas, as crises, a insegurança existente, todos esses efeitos desastrosos e revoltantes do modo de produção capitalista não podem, sobre a base do modo de propriedade atual, ser freados em seus progressos constantes pelas reformas qualquer que seja a extensão que se suponha (Marx, Engels, Lênin, 1971, p.104).
} 
Ademais, o abismo que separa os possuidores e os não possuidores seria alargado pelas crises, que teriam a sua origem na essência do modo de produção capitalista. Estas crises tornar-se-iam cada vez mais extensas e devastadoras, fazendo da insegurança geral o estado normal da sociedade. Somente a transformação da propriedade privada capitalista dos meios de produção em propriedade social e a transformação da produção de mercadorias em produção socialista, isto é, em produção efetuada para e pela a sociedade, poderiam fazer com que a grande exploração e a produtividade crescente do trabalho social se transformassem, de fontes de miséria e de opressão, em fontes do maior bem-estar e de um "aperfeiçoamento harmonioso e universal"304.

Assim, o programa dispunha que a transformação social significaria não apenas a emancipação do proletariado, mas do conjunto do gênero humano, vítima do status quo. Tal transformação, porém, não poderia deixar de ser obra da classe operária, pois todas as outras classes colocar-se-iam no terreno da propriedade privada dos meios de produção e teriam por objetivo comum a conservação dos fundamentos da sociedade atual.

Convém ressaltar que Kautsky anunciava que a evolução econômica da sociedade burguesa levaria, "com a necessidade das leis da natureza", à ruína da pequena exploração, de modo que os meios de produção tornar-se-iam monopólio de um número relativamente pequeno de capitalistas e de grandes proprietários ${ }^{305}$. Como resultado, o número de proletários tornar-se-ia cada vez maior, assim como o exército dos operários supérfluos, aprofundando a oposição entre os exploradores e os explorados e exasperando a luta de classes ${ }^{306}$.

A perspectiva de Kautsky resvala, assim, em uma espécie de "evolucionismo" que equipara a evolução das sociedades à evolução da natureza, revelando a grande influência que a teoria de Darwin teve sobre seu pensamento ${ }^{307}$. Ao enfatizar o caráter "irresistível e necessário" da evolução social, minimiza o papel ativo desempenhado pelos homens neste processo, embora não a extinga por completo:

Quando se fala do caráter irresistível e necessário de uma necessidade natural da evolução social, se supõe que os homens são homens e não corpos inertes, os homens possuem certas necessidades, certas paixões, dotados de certas forças físicas e morais que eles empregam de seu melhor. Uma submissão passiva a isto que parece inevitável não deixa livre o curso da

\footnotetext{
${ }^{304}$ Ibid., p.94-95.

${ }^{305}$ Ibid., p.93.

${ }^{306}$ Ibid., p. 94.

307 "A ciência mais recente nos ensina que na sociedade como na natureza nós podemos observar uma constante evolução" (Kautsky, 1927, p.1).
} 
evolução social, mas a condena ao repouso. Se nós temos por inevitável a abolição da propriedade privada dos meios de produção, nós não pretendemos que em um belo dia a revolução social caia do céu. Nós temos a ruína da sociedade atual por inevitável porque nós sabemos que a evolução econômica cria necessariamente as condições que forçam os explorados a combaterem esta propriedade privada (grifo nosso). Nós sabemos que o nome e a força dos explorados cresce, que o número e a força dos exploradores que se apegam à ordem existente diminuem. Nós sabemos, enfim, que esta evolução cria condições intoleráveis para a massa da população, condições que não deixam a escolha entre o desaparecimento passivo ou a reversão ativa da ordem da propriedade existente $^{308}$.

Embora Kautsky considerasse que todas as tentativas de resolução ou amenização das contradições existentes na ordem capitalista que não implicassem na abolição da propriedade dos meios de produção se mostrariam ineficazes, não menosprezava a necessidade de se efetuar reformas sociais ${ }^{309}$. Assim, Kautsky tentava conciliar seu discurso revolucionário com as demandas imediatas reivindicadas pelos setores reformistas da social-democracia. Neste sentido, destacou que haveria várias maneiras de agir sobre da evolução econômica: poder-seia acelerá-la ou retardá-la, enfraquecer ou reforçar seus efeitos, torná-la mais dolorosa ou menos penosa, segundo a força que se dispõe na sociedade.

Cabe sublinhar, no entanto, que, para Kautsky, "não se pode nem parar esta evolução nem fazê-la andar para trás". Por conseguinte, qualquer pretensão de tornar perene o modo de produção capitalista deveria ser desacreditada, visto que "as forças produtivas que se desenvolvem no seio da sociedade capitalista não são compatíveis com a forma de propriedade que forma sua base". Sendo assim, querer manter esta forma de propriedade seria o equivalente a tornar impossível seu futuro progresso social, condenando a sociedade ao repouso, à degeneração - "mas uma impressionante degeneração em vida, acompanhada de convulsões as mais dolorosas" ${ }^{310}$.

Deste modo, a experiência ensinaria que todos os meios empregados para impedir a evolução da sociedade no sentido do socialismo se mostrariam ineficazes, ou mesmo

\footnotetext{
${ }^{308}$ Ibid, p.102-103.

309 "Nós afirmamos que as reformas sociais são ineficazes em se tratando do objetivo de suprimir a contradição crescente existente entre as forças produtivas e o modo de propriedade atual (...). Mas nós não queremos dizer que a revolução social, a abolição da propriedade privada dos meios de produção se produzirá dela mesma, que a evolução irresistível se conquistará sozinha. Nós não pretendemos que todas as reformas sociais sejam coisas inúteis, e que não reste a estes que sofrem da contradição entre as forças produtivas e o modo de propriedade que cruzar os braços e esperar com resignação que ela desapareça” (Ibid., p.102).

${ }^{310}$ Ibid, p. 101.
} 
agravariam os males que eles deveriam fazer desaparecer. Destarte, "os meios realmente susceptíveis de remediar mais ou menos a um ou outro dos inconvenientes existentes tem por efeito a precipitação do curso da evolução" 311 .

Ao considerar a revolução como algo certo e incontornável, Kautsky admite que a social-democracia volte seus esforços para a luta diária por reformas que amenizem o fardo da classe operária até que chegue o dia da vitória. Assim, Kautsky afirma que a luta do proletariado contra a exploração capitalista seria uma luta necessariamente política, uma vez que "a classe operária não pode conduzir as suas lutas econômicas e desenvolver a sua organização econômica sem direitos políticos", e, sobretudo, "não pode realizar a passagem dos meios de produção para a posse da coletividade sem entrar na posse do poder político" 312 . Tendo isto em vista, a tarefa do Partido Social-Democrata resumir-se-ia a tornar a luta da classe operária consciente e unitária.

Enquanto Kautsky responsabilizou-se pela parte teórica do programa, norteada pela doutrina marxista, coube a Eduard Bernstein a parte prática, contendo as reivindicações concretas e imediatas da social-democracia. Tal divisão de tarefas entre os dois expoentes da social-democracia já evidenciava o fato de que Bernstein possuía maior apego às questões de ordem prática, isto é, às tarefas imediatas da social-democracia, do que às de caráter teórico muito antes de enveredar para o revisionismo.

Dentre as reivindicações práticas da social-democracia, constavam: o sufrágio universal $^{313}$, sistema de representação proporcional ${ }^{314}$, reformas na legislação eleitoral ${ }^{315}$, direitos civis e políticos plenos $^{316}$ para ambos os sexos, reformas administrativas ${ }^{317}$, reformulação da política militar ${ }^{318}$, laicização do Estado $^{319}$, reforma educacional ${ }^{320}$, reforma

\footnotetext{
${ }^{311}$ Ibid, p.104.

${ }^{312}$ Marx, Engels, Lênin, 1971, p.95.

${ }^{313} \mathrm{O}$ voto passaria a ser igual, direto e em escrutínio secreto para todos os membros do Império com mais de vinte anos, sem distinção de sexo, em todas as eleições e em todas as votações (Ibid, p.96).

314 Até que este fosse estabelecido propõe que seja realizada uma nova modificação legal das circunscrições eleitorais após cada recenseamento (Ibid, p.96).

${ }^{315}$ Como, por exemplo, períodos legislativos com duração de dois anos, dias de eleições e de votações marcados para o dia de descanso legal e indenização dos representantes eleito (Ibid, p.96-97).

${ }^{316}$ Abolição de todas as leis que limitam ou suprimem a livre expressão da opinião e o direito de associação e de reunião, além da abolição de todas as leis que, do ponto de vista do direito público e privado, colocam a mulher em estado de inferioridade em relação ao homem (Ibid, p.96-97).

${ }^{317}$ Inclusão da possibilidade de legislação pelo povo por meio do direito de iniciativa e de veto, autonomia administrativa do povo no Império, no Estado, na província e na comuna, eleição dos funcionários pelo povo e responsabilidade penal destes últimos (Ibid, p.96-97).

318 Propunha a educação para o serviço militar para todos, milícias em substituição aos exércitos permanentes, representação popular como a única chamada a decidir sobre questões relacionados à guerra e à paz e a regulação de todos os conflitos internacionais por via da arbitragem (Ibid, p.96-97).
} 
judiciária $^{321}$, gratuidade da assistência médica ${ }^{322}$ e instituição de imposto progressivo sobre os rendimentos e a fortuna ${ }^{323}$. Além destas medidas, o Programa de Erfurt elenca ainda tarefas urgentes destinadas à proteção da classe operária, como a implementação de uma eficaz legislação protetora do trabalho ${ }^{324}$.

Tendo analisado o projeto de programa formulado por Kautsky e Bernstein, Engels lhe direcionou importantes observações críticas, publicadas posteriormente à morte de Liebknecht - em 1901 - sob a forma de um artigo na Neue Zeit, intitulado "Contribuição para a Crítica do Projeto de Programa Social-Democrata". Em uma carta dirigida a Kautsky, datada de 29 de junho de 1891, Engels justifica esta iniciativa, mostrando-se preocupado com a possibilidade de o programa "desancar no pacífico oportunismo" e na "passagem tranqüila deste velho lamaçal para a sociedade socialista" 325 .

Em sua crítica ao programa, Engels elogia o fato de o novo projeto ter eliminado "os numerosos resquícios de uma tradição envelhecida - quer especificamente lassalliana quer socialista vulgar, ${ }^{, 326}$. Todavia, adverte aos autores - em especial Bernstein ${ }^{327}$ - em relação a

${ }^{319}$ Declarar a religião assunto privado, suprimir todas as despesas feitas através dos fundos públicos para fins eclesiásticos e religiosos, considerar as comunidades eclesiásticas e religiosas como associações privadas que regulam os seus assuntos com plena independência, laicizar a escola (Ibid, p.96-97).

320 "Frequiência obrigatória nas escolas populares públicas, gratuidade do ensino, dos materiais escolares e de manutenção nas escolas populares públicas, bem como nos estabelecimentos de instrução superior para os estudantes que, em virtude das suas capacidades, se considera que devem receber uma instrução mais elevada" (Ibid, p. 96-97).

${ }^{321}$ Gratuidade da justiça e da assistência judicial, justiça promovida por juízes eleitos pelo povo, apelação em matéria penal, indenizações para as pessoas acusadas, presas e condenadas reconhecidas inocentes e supressão da pena de morte (Ibid, p. 96-97).

${ }_{322}$ Compreendendo os partos e os remédios e a gratuidade dos enterros (Ibid, p. 96-97).

${ }^{323}$ Isto implica na declaração obrigatória dos rendimentos, imposto progressivo sobre as sucessões de acordo com a importância da herança e com o grau de parentesco, abolição de todos os impostos indiretos, direitos aduaneiros e outras medidas econômicas que sacrificam os interesses da coletividade aos interesses de uma minoria privilegiada (Ibid, p. 96-97).

${ }^{324}$ Legislação nacional e internacional, nas seguintes bases: fixação de um dia de trabalho normal de, no máximo, oito horas; proibição do trabalho industrial para as crianças com menos de quatorze anos; proibição do trabalho noturno, salvo para os ramos de indústria que, devido à sua natureza, quer por razões técnicas, quer por razões de bem-estar geral, o exigem; um intervalo de descanso ininterrupto de, pelo menos, trinta e seis horas, uma vez por semana, para cada operário; proibição do "truck-system" (pagamento dos operários em mercadorias); fiscalização de todas as explorações industriais, inquéritos às condições de trabalho na cidade e no campo e regulamentação das condições do trabalho por uma repartição imperial do trabalho, repartições distritais do trabalho e câmaras de trabalho; higiene industrial rigorosamente observada; a mesma situação para os operários agrícolas e empregados domésticos e para os trabalhadores industriais; supressão dos regulamentos respeitantes aos empregados domésticos; direito de coligação assegurado; seguro operário inteiramente a cargo do Império com participação determinante dos operários na sua administração (Ibid, p. 96-97).

325 "Pareceu-me que era mais importante expor os defeitos, em parte evitáveis e em parte inevitáveis, do programa político, pois era uma ocasião de desancar no pacífico oportunismo... e na "passagem" tranqüila deste velho lamaçal para a "sociedade socialista" (Marx, Engels, Lênin, 1971, p.39).

${ }^{326}$ Assim, considera que, "do ponto de vista teórico, o projeto mantém-se, no seu conjunto, no terreno da ciência atual e é possível discuti-lo colocando-nos neste terreno" (Ibid., p.41). Em entrevista ao Daily Chronicle, de junho de 1893, Engels voltou a elogiar o programa: "Nosso programa é puramente socialista. Nossa principal 
um grande defeito presente nas reivindicações políticas do projeto: a ausência de qualquer referência à ação revolucionária, ou, ao menos, à reivindicação da concentração de todo o poder político nas mãos da representação do povo através do estabelecimento de uma república unitária ${ }^{328}$.

Para Engels, mesmo sendo verdade que as reformas propostas possam oferecer mais alguns meios para que se alcance a reivindicação principal, sozinhas elas não seriam suficientes para atendê-la ${ }^{329}$. O autor, então, alerta para o perigo de se deixar atrair pelo "oportunismo que começa a propagar-se numa grande parte da imprensa social-democrata", que se apresenta na forma de um mero reformismo:

Com medo de uma renovação da lei contra os socialistas ou lembrando-se de certas opiniões emitidas prematuramente no tempo em que essa lei estava em vigor, pretende-se agora que o partido reconheça a atual ordem legal na Alemanha como suficiente para fazer realizar todas as suas reivindicações pela via pacífica. Faz-se acreditar a si próprio e ao partido que "a sociedade atual, ao desenvolver-se, passa pouco a pouco para o socialismo", sem se perguntar se, para isso, ela não será obrigada a sair da sua velha carapaça com tanta violência como o lagostim do rio rebenta a sua; como se, na Alemanha não tivesse, além disso, que romper os entraves da ordem política ainda semi-absolutista e, ainda por cima, indescritivelmente baralhada ${ }^{330}$.

De acordo com Engels, poder-se-ia conceber que a velha sociedade pudesse "evoluir pacificamente para a nova" nos países em que a representação popular concentrasse em si todo o poder; onde, segundo a constituição, se pudesse fazer o que se quer, desde que se tivesse por trás de si a maioria da nação. Sendo assim, em "repúblicas democráticas" como a França e a América e em monarquias como a Inglaterra, em que "o resgate iminente da dinastia é debatido todos os dias na imprensa e onde esta dinastia é impotente contra a

plataforma é a socialização de todos os meios e instrumentos de produção. Ainda assim nós aceitamos tudo o que qualquer governo possa nos dar, mas apenas como um acerto de contas, e pelo o qual nós não agradecemos. Nós sempre votamos contra o orçamento e contra qualquer requerimento de dinheiro ou homens para o Exército. Em locais em que nós não tivemos um candidato em que votar no segundo turno nossos apoiadores foram instruídos a votar apenas nos candidatos que alegavam votar contra a Lei do Exército, qualquer aumento de impostos e qualquer restrição dos direitos do povo" (www.marxists.org).

${ }^{327}$ Embora Engels não direcione as críticas especificamente a Bernstein, estava ciente de que o mesmo foi o encarregado pela elaboração da parte prática do programa.

${ }^{328}$ Engels deixa claro que não descarta a via insurrecional, ao acrescentar que, diante da ameaça de novas leis socialistas, "isto bastaria por agora, se não se pode ir mais além” (Ibid, p.49).

${ }^{329}$ Ibid., p.46.

${ }^{330}$ Ibid., p.47. 
vontade do povo"331. Contrariamente, na Alemanha, "onde o governo é quase todo-poderoso, onde o Reichstag e os outros corpos representativos não têm poder efetivo", proclamar tais idéias seria "tirar a folha de parreira ao absolutismo e cobrir a sua nudez com o próprio corpo" ${ }^{, 332}$.

Deste modo, Engels invalida a proposta política dos reformistas, alegando que a defesa da via legal na Alemanha, a longo prazo, só poderia arrastar o partido para um "caminho falso", pois, por um lado colocaria em primeiro plano problemas políticos gerais, abstratos, e por outro esconderia os problemas concretos mais prementes, os quais, nos primeiros acontecimentos importantes, na primeira crise política, vêm por si próprios inscrever-se na ordem do dia. Engels, então, infere: "que pode resultar disto senão que, de repente, no momento decisivo, o partido será apanhado de surpresa e nos pontos decisivos reinará a confusão e a ausência de unidade, porque estes problemas não terão nunca sido discutidos ? $^{333}$

As considerações críticas de Engels tinham como alvo os setores "oportunistas" do partido, que defendiam "o esquecimento das grandes considerações essenciais perante os interesses passageiros do dia, esta corrida aos sucessos efêmeros e a luta que se trava em torno deles sem ter em atenção às conseqüências ulteriores, este abandono do futuro do movimento que se sacrifica ao presente",334.

Como Engels temia, precisamente esta ala da social-democracia saiu fortalecida com a aprovação do novo programa. Ao subordinarem a vontade subjetiva do proletariado às condições objetivas necessárias para se alcançar o socialismo, os membros da corrente majoritária do partido - conhecidos como "marxistas ortodoxos", ou, "marxistas da Segunda Internacional" - limitavam a luta à política parlamentar e à implementação de reformas legais. Assim, a expectativa de uma revolução futura justificava a concentração da atividade presente na luta por reformas, inibindo quaisquer pretensões insurrecionais contra as instituições estatais. Como Bebel explicitara,

\footnotetext{
${ }^{331}$ Contudo, esta possibilidade dependeria da chegada ao poder do operariado. Em "Contribuição ao problema da habitação", de 1872, Engels advertira, a respeito do governo liberal existente na Inglaterra, cujo princípio é "não propor leis de reformas sociais senão obrigados pela necessidade, e fazer todo o possível para não aplicar as já existentes. (...) É claro como a luz do dia que o Estado atual não é senão o poder organizado conjunto das classes possuidoras, dos latifundiários e dos capitalistas, dirigido contra as classes exploradas, os camponeses e os operários. O que os capitalistas (...) tomados individualmente não querem, seu Estado não quer tampouco. (...) $\mathrm{O}$ Estado se preocupará, no máximo, em conseguir que as medidas usuais, que representam um paliativo superficial sejam aplicadas" (Marx, Engels, 1980b, p.156).

${ }^{332}$ Marx, Engels, Lênin, 1971, p.47.

${ }^{333}$ Ibid., p.48.

${ }^{334}$ Ibid.
} 
Se - como não há razão para duvidar - as coisas continuarem a se desenvolver nessa direção, considero possível que, em certo momento, as classes dominantes terminem por ser lançadas num estado hipnótico e deixem as coisas seguirem o seu curso, sem quase opor resistência (...). A condição é que o desenvolvimento possa chegar à plena maturação, sem ser perturbada por incidentes imprevistos e que a explosão não ocorra prematuramente. ${ }^{335}$

O emprego da "estratégia do desgaste"336, ao invés da "estratégia do aniquilamento", isto é, o apego à idéia de que se deva aguardar o momento apropriado, quando as condições objetivas estejam suficientemente maduras, para que se efetue a conquista do poder estatal através da conquista da maioria do parlamento, admitia o uso da força apenas de modo excepcional, como um meio defensivo de manutenção do poder após a conquista da vitória parlamentar. Planejava-se formar um consenso eleitoral que conduzisse à maioria no governo e ao redirecionamento da política estatal.

Em discurso endereçado ao Congresso de Erfurt, Liebknecht defendeu a tática parlamentar contra os ataques das correntes esquerdistas, sustentando que seu posicionamento conservaria o caráter revolucionário, por manter-se fiel ao objetivo final:

O parlamentarismo é simplesmente o sistema de representação do povo. Se até agora não temos conseguido resultados no Reichstag a culpa não é do parlamentarismo: é apenas a conseqüência de que não temos todavia, neste país, no povo, o poder necessário. Se tivéssemos atrás de nós tantos votos e tanta força como têm os partidos burgueses, o Reichstag seria para nós tão pouco infrutífero quanto é para eles... Dizer isto não é sustentar que todo problema pode ser resolvido mediante a legislação, mas que alguém me ensine outro caminho que chegue ao nosso fim: Sei que há outro caminho, o qual, na opinião de alguns poucos de nós, é mais curto: o da violência ... mas esse caminho conduz ao anarquismo, e é grande culpa da oposição não haver se dado conta deste resultado... com o passar do tempo a mera força deve ceder aos fatores morais, à lógica das coisas. Bismarck, o homem da força bruta, o homem da política do ferro e sangue, jaz prostrado e a socialdemocracia é o partido mais forte da Alemanha... A essência do revolucionarismo está, não nos meios, mas nos fins (grifo

\footnotetext{
${ }^{335}$ Carta de Bebel a Engels de 28 de março de 1881 (STEINBERG, Hans-Josef. "O partido e a formação da ortodoxia marxista". História do marxismo II: o marxismo na época da Segunda Internacional - primeira parte.I Eric J. Hobsbawm (org). Rio de Janeiro: Paz e Terra, 1982, p.212).

${ }^{336}$ Como explicou Kautsky, em 1909: "A estratégia do desgaste diferencia-se da do aniquilamento apenas pelo fato de que a primeira não visa diretamente à batalha decisiva, como o faz a segunda, mas a prepara durante um longo tempo e só se dispõe a travar essa batalha quando considera o inimigo suficientemente enfraquecido" (KAUTSKY, apud, SALVADORI, Massimo L. "Kautsky entre ortodoxia e revisionismo". In: História do marxismo II: o marxismo na época da Segunda Internacional - primeira parte./ Eric J. Hobsbawm (org). Rio de Janeiro: Paz e Terra, 1982, p.330).
} 
nosso). A violência tem sido durante milhares de anos um fator de reação. Prove que nosso fim é falso e então poderá dizer que ${ }_{337}$ partido foi afastado por seus chefes do caminho da revolução.

Diante das inúmeras críticas emanadas por membros do partido e do aumento da desconfiança em relação ao grupo parlamentar, acusado de oportunismo, Wilhelm Liebknecht colocou em destaque a distinção entre princípios essenciais (fins) e não-essenciais (meios) ${ }^{338}$ da social-democracia. Deste modo, no intuito de validar a tática reformista - que pregava uma transição pacífica e gradual ao socialismo, por meio de um contínuo trabalho de propaganda vociferou pela adoção de uma tática realista ${ }^{339}$ e pragmática, que poderia variar de acordo com as circunstâncias, uma vez que nestas questões "os interesses do partido são a única lei”. Contudo, diferentemente de Engels, Liebknecht apoiou a renúncia, de antemão, às "violentas frases revolucionárias" ${ }^{340}$, que a seu ver serviriam mais à reação do que à revolução.

Embora os líderes do partido vinculados ao "marxismo ortodoxo" conservassem no horizonte a idéia do inexorável objetivo final, o foco em questões imediatas tornou seu conteúdo cada vez mais vazio e abstrato. O discurso de Bebel no Reichstag, em 1893, vem a comprovar tal assertiva, ao alegar: "não nos dedicamos a projetar detalhes utópicos, e a dizer: a sociedade socialista tem que ser assim e assim. Esta se faz a si mesma". 341

A interpretação evolucionista do materialismo histórico, realizada por dirigentes e intelectuais do SPD - como Kautsky e Bebel -, resultante de uma síntese entre marxismo e

\footnotetext{
${ }^{337}$ WALDENBERG, Marek. "A estratégia política da social-democracia alemã”. In: História do marxismo II: o marxismo na época da Segunda Internacional - primeira parte./ Eric J. Hobsbawm (org). Rio de Janeiro: Paz e Terra, 1982, p.244.

338 "Questões de tática são questões práticas e podem ser distinguidas das questões de princípios. Nós temos visto que não é justificável manter que a força é a única tática revolucionária adequada e que um homem não precisa ser chamado de reacionário se ele não aprova o uso desta tática em todos os casos. Nós mostramos que a força não é sempre revolucionária mas que às vezes é anti-revolucionária. Nós mostramos a necessidade de nos emanciparmos das frases e buscarmos a força do partido na clareza do pensamento, na ação metódica e destemida, e não em violentas frases revolucionárias que freqüentemente só escondem desejo de clareza e ação. Nós mostramos que para que o partido seja capaz de realizar idéias socialistas ele deve ser capaz de obter o necessário poder e que isto deve ser feito antes de tudo pelos meios de propaganda. (...) Mas nós não passaremos para o socialismo de só uma vez. A transição se faz gradualmente, e não é nossa tarefa desenhar o esboço do futuro (que seria trabalho inútil), mas determinar o programa prático para o período de transição, formular e justificar medidas que possam ser aplicáveis imediatamente no presente estado da sociedade e possam contribuir para trazer um melhor estado de coisas" (LIEBKNECHT. "How it could be done". In: Justice, 7/9/1901www.marxists.org.).

${ }^{339}$ Em declaração de 1892, Liebknecht afirma: "Esta é, na verdade, a grande vantagem do movimento alemão, uma vantagem que não provém de nossos méritos pessoais mas do curso da nossa evolução histórica peculiar (...). Trata-se de que desde o primeiro momento o movimento alemão teve um programa baseado em princípios firmes, uma atitude científica e uma tática realista (Realpolitische)" (JOLL, James. La Segunda Internacional. Movimiento obrero 1889-1914. Barcelona: Icalia, 1976, p.65).

${ }^{340}$ LIEBKNECHT. "How it could be done". In: Justice, 7/9/1901- www.marxists.org.

${ }^{341}$ Gustafsson, 1975, p.35.
} 
darwinismo, assentava suas bases na idéia de que o fim da sociedade capitalista seria decorrente de uma "necessidade natural", expressa através de sucessivas crises e depressões econômicas. Desta maneira, a perspectiva fatalista de um colapso geral ("Zusammenbruch") da ordem política e social existente, ou nas palavras de August Bebel, o "grande zás-trás" ("der grosse Kladderadatsch") ${ }^{342}$, desembocou no imobilismo e no gradualismo, que excluíam táticas ilegais ou pela via extra-parlamentar.

Em suma, a apropriação da teoria de Marx e Engels pela primeira geração de "marxistas", cuja preocupação primordial residia na aplicação prática dos princípios visando resultados a curto e médio prazo, originou uma doutrina que conjugava determinismo econômico e ideologia do progresso, levando à consolidação de uma tática reformista e à concepção de que a revolução não é algo que possa ser feito ${ }^{343}$.

Se, como argumenta Schorske, o Programa de Erfurt foi desenhado para um período não-revolucionário, em que a classe trabalhadora estava crescendo em números e consciência política, mas estava ainda muito fraca para fazer uma séria investida pelo poder $^{344}$, não deixou de expressar igualmente uma necessidade de unificação do movimento social-democrata em torno de princípios partidários, ainda que estes tenham se subordinado à prática reformista ${ }^{345}$.

Com efeito, o Programa de Erfurt, acometido de um espírito conciliador, procurou satisfazer às duas tendências antagonistas dentro do movimento operário, aderindo tanto a uma fraseologia revolucionária como a uma tática reformista. Assim, a tese da inevitabilidade histórica do declínio do capitalismo e do triunfo do socialismo cumpria uma função ideológica, motivando os trabalhadores na sua luta cotidiana. Consoante nos explica Marek Waldenberg:

A tese correspondia às exigências psicológicas das massas proletárias; e isso em proporção tanto maior quanto mais as relações sociais e o sistema político provocavam a discriminação dos proletários, ao considerá-los como uma categoria de cidadãos perigosos que deviam ser isolados do

\footnotetext{
${ }^{342}$ STEINBERG, Hans-Josef. "O partido e a formação da ortodoxia marxista”. História do marxismo II: o marxismo na época da Segunda Internacional - primeira parte./ Eric J. Hobsbawm (org). Rio de Janeiro: Paz e Terra, 1982, p. 210-211.

${ }^{343}$ Conforme Hans-Josef Steinberg observou, "o que estava presente em Marx sob uma forma tendencial, sob a forma de um princípio dinâmico do capitalismo, passou a aparecer como uma lei histórica universalmente válida; e o que era para Marx um princípio dialético do movimento histórico configurou-se como evolução pura e simples, em cujo término está - quase como um evento natural - a revolução social: o proletariado deve se preparar para ela por meio da organização" (Ibid, p.209).

344 SCHORSKE, Carl E. German social democracy. 1905- 1917: The development of the great schism. New York: Harper Torchbooks, 1972, p.6.

345 Cf. MUSSE, Ricardo. Do socialismo científico à teoria crítica: modificações na autocompreensão do marxismo entre 1878 e 1937. São Paulo: USP/FFLCH [Tese], 1998, cap.III.
} 
resto da nação. Juntamente com a tese sobre a importância histórica do proletariado, ela dava às massas operárias o sentimento de seu próprio valor de classe e o valor do operário singular enquanto elemento da força coletiva que liberaria a humanidade inteira da exploração, da opressão, do envilecimento e da miséria. ${ }^{346}$

Todavia, ao mesmo tempo em que fortalecia a auto-estima e a identidade de classe dos operários, a teoria do colapso - com sua concepção evolucionista e naturalista da história retirava-lhes da condição de sujeitos históricos e atribuía-lhes um papel secundário, de simples expectadores do processo histórico, aplacando, assim, seu ímpeto revolucionário. Como observou Walter Benjamin:

O conformismo que, desde o início, sentiu-se em casa na socialdemocracia, adere não só à sua tática política, mas também às suas idéias econômicas. Ela é uma das causas do colapso ulterior. Não há nada que tenha corrompido tanto o operariado alemão quanto a crença de que ele nadava com a correnteza ${ }^{347}$.

Como veremos adiante, as ambigüidades e contradições presentes no programa e na prática da social-democracia logo foram evidenciadas diante das mudanças conjunturais no final do século XIX, levando à progressiva desagregação do partido em várias correntes.

\section{4- Cisão interna e fortalecimento do reformismo}

Com a abertura política e o êxito eleitoral conquistado ao longo da década de 1890, cada vez mais grupos dentro do partido passaram a pressionar no sentido de uma revisão programática que pusesse fim à proibição de coalizões e participações no governo e assumisse o caráter puramente reformista do SPD. Muitos líderes da social-democracia compartilhavam desta opinião e iam mais além nas suas afirmações. É o caso de Georg von Vollmar, deputado pelo Landtag da Baviera que, até então, fazia parte da ala esquerda do partido. Em um discurso pronunciado em Munique, em junho de 1891, mais conhecido como o "Discurso de Eldorado", Vollmar põe em questão as previsões de Marx a respeito da agricultura e da indústria, ou seja, a tendência à crescente polarização das classes e concentração do capital, à

\footnotetext{
${ }^{346}$ WALDENBERG, Marek. "A estratégia política da social-democracia alemã”. In: História do marxismo II: o marxismo na época da Segunda Internacional - primeira parte./ Eric J. Hobsbawm (org). Rio de Janeiro: Paz e Terra, 1982, p.226.

${ }^{347}$ LÖWY, Michael. Walter Benjamin: aviso de incêndio. São Paulo: Boitempo, 2005, p.100.
} 
ruína dos pequenos proprietários e à proletarização das massas. Com efeito, defendia a lenta evolução orgânica da sociedade realizada através de reformas:

Além do objetivo geral final nós vemos uma meta mais próxima: o avanço das necessidades mais imediatas do povo. Para mim, a conquista das reivindicações mais imediatas é o principal, não apenas porque elas são de grande valor propagandístico e servem para aliciar as massas, mas também porque em minha opinião este progresso gradual, esta socialização gradual, é o método mais forte indicado para a transição progressiva [grifo nosso]. Assim, o caminho da calma, legal, atividade parlamentar no sentido mais amplo, está dado, pois a mudança no sentimento popular trará a correspondente mudança no Reichstag ${ }^{348}$.

Precisamente a defesa do reformismo, não apenas como mero artifício político para arregimentar novos membros e eleitores, mas como meio para a realização do socialismo será a pedra de toque do revisionismo de Eduard Bernstein, como veremos mais à frente. A concepção evolucionista de Vollmar levou-o, igualmente, a rejeitar a idéia de um desenvolvimento histórico realizado por "saltos revolucionários":

Até agora aconteceram grandes crises em que a História dava um salto ou parecia dá-lo. Do mesmo modo em que as relações naturais não se desenvolvem através de transformações em sucessão sincopada súbita e imediata, assim as ordens sociais não se substituem umas às outras como unidades fechadas, imediatas $^{349}$.

A conversão do Estado em mecanismo propulsor de reformas sociais, ou seja, a tática de "utilizar as formas atuais para exercer uma influência sobre as de amanhã" conduziu Vollmar a endossar as teses dos "socialistas de Estado" que olhavam com extremo otimismo para o "novo curso" da política do governo. Do seu ponto de vista, a social-democracia deveria revisar sua tática: lutar para introduzir sobre a base da ordenação social e estatal melhorias políticas e econômicas ${ }^{350}$. Consoante Vollmar,

A social-democracia não tem nenhum motivo para combater com particular zelo as idéias do socialismo de Estado em si. Se, ao contrário, estabelecêssemos uma série de medidas propugnadas por nós para gradualmente dar andamento a uma

\footnotetext{
348 VOLLMAR, apud, GAY, Peter. The dilemma of democratic socialism. New York: Columbia University Press, 1970, p. 258.

349 VOLLMAR, apud, GUSTAFSSON, Bo. Marxismo y revisionismo: La critica bernsteiniana del marxismo y sus premisas histórico-ideológicas. México: Grijaldo, 1975, p.28.

${ }^{350}$ VOLLMAR, apud, DROZ, Jacques. Histoire générale du socialisme - tomo II. Paris: Presses Universitaires de France, 1974, p. 31.
} 
nova ordem social, então poderíamos ver quais destas podem ser caracterizadas justamente como socialistas de Estado ${ }^{351}$.

$\mathrm{Na}$ assembléia do partido, realizada em 1892, em Berlim, Liebknecht expressou seu descontentamento em relação à defesa de Vollmar de um socialismo de Estado e das vantagens da nacionalização, enfatizando os perigos de se estender o poder e a autoridade do Estado existente. Para Liebknecht, "quando o Estado existente se encarrega de algo, não muda sua natureza. Ocupa o lugar do dono de uma empresa privada: os operários não melhoram em nada, mas o Estado reforça seu poder e sua capacidade de opressão". 352

Ainda em 1892, no Congresso do Partido Social-Democrata bávaro, em Ratisbonne, Vollmar apresentou um projeto de reformas, com vistas a atrair o eleitorado rural da influência do Partido do Centro e dos Conservadores. Através desta ação pretendia limitar a influência da Liga dos Proprietários Rurais (Bund der Landwirte) - organização conservadora e protecionista que buscava uma ação conjunta entre os grandes proprietários e os camponeses - pela incorporação de demandas sociais que atendessem tanto aos interesses dos trabalhadores agrícolas como dos pequenos e médios proprietários rurais, como por exemplo, a nacionalização das hipotecas, o monopólio do crédito agrícola pelo Estado, a redução da taxa de juros do crédito agrícola, a possibilidade de exploração de bosques e dos bens comunais e o fomento a cooperativas agrícolas.

Tais proposições já haviam sido alvo das críticas de Engels. Em "O problema camponês na França e na Alemanha", escrito em novembro de $1894^{353}$, o autor identificava os camponeses como "um fator essencial da população, da produção e do poder político". Contudo, segundo a análise de Engels, o avanço do capitalismo conduziria ao seu deslocamento para o segundo plano em termos econômicos e políticos e, por fim, à eliminação deste grupo social $^{354}$. Tendo em vista que o desenvolvimento do modo de

\footnotetext{
${ }^{351}$ Vollmar, apud, Gustaffson, 1975, p.29.

${ }^{352}$ COLE, George Douglas Howard. Historia del pensamiento socialista: la segunda internacional: $1889-1914$. México: Fondo de Cultura Economica, v.1, 1959, p.262.

${ }_{353}$ Publicado na revista Neue Zeit, p.225 a 243 (Marx; Engels, 1980c, p.225-143).

${ }^{354}$ Tal previsão já havia sido apresentada por Engels no segundo prefácio à "Contribuição ao Problema da habitação", de 1887: "Como Marx já demonstrou (....) em certo grau de desenvolvimento a máquina e a fábrica farão soar também para elas a hora da decadência. E essa hora parece estar próxima. Mas a destruição da indústria domiciliar e da manufatura rurais pela máquina e a fábrica significam, na Alemanha, a destruição dos meios de existência de milhões de produtores rurais, a expropriação de quase a metade do pequeno camponês, a transformação não somente da indústria a domicílio em produção fabril, mas também da economia camponesa em grande agricultura capitalista e da pequena propriedade territorial em grandes domínios: uma revolução industrial e agrária em proveito da grande propriedade territorial e em detrimento dos camponeses. Se o destino da Alemanha é passar também por tal transformação nas velhas condições sociais, isso seria indiscutivelmente um ponto de virada" (Marx, Engels, 1980b, p.115).
} 
produção capitalista estaria "matando o nervo vital" da pequena exploração da agricultura que tenderia a decair e a marchar, irremediavelmente, para a ruína ${ }^{355}$ - Engels endereçou algumas críticas aos socialistas franceses de tendência marxista, que formularam o primeiro programa agrário social-democrata, aprovado no Congresso de Marselha de $1892^{356}$ - cuja fundamentação teórica foi exposta no Congresso de Nantes, em setembro de 1894.

Engels considerava improvável que os camponeses pudessem converter-se em aliados da social-democracia, na medida em que a conquista da massa camponesa dependeria da realização de promessas que os social-democratas não poderiam cumprir, uma vez que teriam que assumir a defesa de sua propriedade parcelar contra toda eventualidade decorrente dos "poderes econômicos em ação". Assim, o desejo de proteger os pequenos lavradores, no que se refere a sua propriedade, só faria prolongar uma situação anacrônica na qual aqueles "não podem nem viver nem morrer" 357 . Ao contrário, diz Engels, "o fundamental, hoje e em qualquer época, é que os camponeses compreendam que só poderemos salvá-los e conservar em suas mãos a posse de sua casa e de suas terras através de sua transformação ${ }^{358}$ em propriedade e exploração coletivas" 359 .

\footnotetext{
${ }^{355}$ Ibid, p. 226. De acordo com Engels, a situação do camponês seria agravada pela perda do antigo direito aos bens comunais (do servo ou vassalo), da proteção pela comunidade autônoma de que era membro e da participação no usufruto dos bens comunais. A sobrecarga de impostos, colheitas ruins, partilhas de heranças e litígios os levariam a recorrer a usurários e acumularem dívidas. Assim, "nosso pequeno camponês, como todo resto de um modo de produção já caduco, está irremediavelmente condenado a desaparecer. O pequeno lavrador é um futuro proletário" (Marx, Engels, 1980b, p.228).

${ }^{356}$ Este programa exigia para os trabalhadores do campo: salários mínimos fixados pelos sindicatos e conselhos municipais, tribunais industriais e agrícolas (metade dos quais deveria ser constituída por operários), proibição da venda dos terrenos comunais, arrendamento da terra do Estado aos municípios, arrendamento de todas as terras (próprias ou arrendadas) dos municípios a associações de operários agrícolas sem-terras para que cultivem em comum (sob a fiscalização dos municípios e sob a proibição de emprego de trabalho assalariado), além de pensões para velhos e inválidos (instaurando-se para isso um imposto especial sobre a grande propriedade

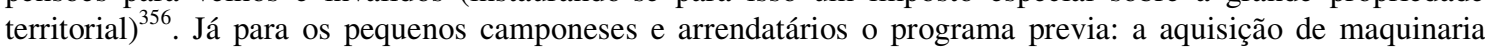
agrícola pelos municípios (a fim de alugá-la, a preço de custo, aos camponeses), criação de cooperativas camponesas para a compra de adubos, sementes, tubos de encanamento para drenagem e irrigação, etc, assim como para a venda de produtos, supressão dos impostos nas transmissões de terras, quando seu valor não exceder 5000 francos, comissões de arbitragem, segundo o modelo irlandês, para fazer baixar as rendas excessivas da terra e para indenizar os colonos e parceiros pelas benfeitorias introduzidas por eles, derrogação do artigo 2102 do Código Civil que outorga ao proprietário da terra o direito de embargo sobre a colheita, abolição do direito dos credores de penhoar a colheita, fixação de um montante impenhorável de instrumentos, sementes, gado, etc, em resumo daquilo que é necessário ao camponês para a exploração de sua economia; revisão do cadastro geral de propriedade, cursos agrícolas gratuitos de aperfeiçoamento e estações agrícolas experimentais (Marx, Engels, 1980b, p.229).

${ }^{357}$ Marx, Engels, 1980b, p.231.

${ }^{358}$ Engels, então adverte que "ao tomarmos posse do poder do Estado, não poderemos pensar em expropriar violentamente os pequenos camponeses (com indenização ou sem ela), como seremos obrigados a fazer com os grandes latifundiários. Face aos pequenos camponeses, nossa missão consistirá, antes de tudo, em orientar sua produção individual e sua propriedade privada para um regime cooperativo - não pela força e sim pelo exemplo e oferecendo-lhes a ajuda social para esse fim" (Marx, Engels, 1980b, p.237).

${ }^{359}$ Ibid, p.238.
} 
A despeito das afirmações de Engels, Vollmar declarou, mais uma vez, diante do Congresso Social-Democrata em Frankfurt, em outubro de 1894, a necessidade de se criar um programa agrário, tendo recebido apoio por parte de Eduard David ${ }^{360}$, deputado de Hesse, e Bruno Schönlank, deputado da Saxônia e redator da Leipziger Volkszeitung. O Congresso criou, assim, uma Comissão Agrária composta por 15 membros, que contava, inclusive, com a participação de $\mathrm{Bebel}^{361}$. Contudo, as proposições da Comissão foram recusadas pelo Plenário do Congresso por maioria de 138 votos contra e somente 6 a favor. No ano seguinte, no Congresso de Breslau de outubro de 1895, as idéias de Vollmar sofreram uma derrota ainda maior. No entanto, havia sido dado o primeiro passo para a formação de uma nova corrente política no interior da social-democracia alemã. ${ }^{362}$

A linha reformista, seguida principalmente pelos social-democratas do sul da Alemanha, suscitou sérias críticas ao Programa de Erfurt, no tocante aos seus objetivos práticos e a forma como estes seriam alcançados. Pertencendo, geralmente, a Estados preponderantemente rurais, estes reformistas exigiam a adequação das táticas às circunstâncias sociais encontradas em seus países. Sendo assim, as questões de ordem teórica não eram atacadas, senão tangencialmente. $\mathrm{O}$ verdadeiro alvo dos reformistas seria a postura "inflexível" e "imobilizadora" sustentada pelos líderes do partido. Para grande parte deles, portanto, a meta socialista poderia permanecer integralmente, desde que não impusesse limites ou obstáculos às mudanças práticas imediatas.

Além de reivindicarem a reformulação da política oficial de alianças, pois necessitavam unir forças com partidos liberais progressistas para não sucumbirem à força política dos Junkers nos Estados do sul e do oeste do Império Germânico, os reformistas defendiam a sua atuação "positiva" nos Landtags, através da sua participação na votação do

\footnotetext{
${ }^{360}$ Eduard David mais tarde rebateria as críticas elaboradas por Kautsky e esboçadas em seu livro "A questão agrária”, de 1899. Neste Kautsky defende que o processo de proletarização dos pequenos camponeses seria inevitável, pois a agricultura se desenvolveria na mesma direção que a indústria, diminuindo o número de proprietários, de modo que os pequenos proprietários de terras tenderiam a desaparecer. Assim, os camponeses representariam elementos reacionários e anacrônicos, aliados aos Junkers contra a burguesia. Em seu livro "Socialismo e agricultura", David coloca em dúvida as conclusões de Kautsky a respeito do processo de concentração da grande propriedade rural e de desaparição dos pequenos proprietários rurais. Almejava a formação de um partido popular que unisse trabalhadores, camponeses e a pequena burguesia contra a classe feudal e capitalista. Para David, a pequena propriedade rural seria a forma ideal de produção rural (Gustafsson, 1975).

${ }^{361}$ Nesta época, Engels publicou na Die Neue Zeit um estudo sobre a questão dos camponeses na França e na Alemanha, onde ele se recusava a apoiar a propriedade privada camponesa.

${ }^{362}$ As orientações reformistas aos poucos foram se agrupando em torno da revista em Sozialistische Monatshefte, órgão independente do partido, dirigido por Josef Bloch, que contava com o apoio de Vollmar, Grillenberger, Max Schippel, Paul Kampffmeyer, Wolfgang Heine, Heinrich Peus, Eduard David, Ignaz Auer e Eduard Bernstein.
} 
orçamento, na medida em que poderiam aprovar medidas que beneficiassem à classe trabalhadora ${ }^{363}$, principalmente nos Estados que desfrutavam de maior liberdade civil e política. Na concepção de Vollmar, portanto, "para obter concessões é necessário negociar, transigir ao invés de lutar" ${ }^{364}$. Deste modo, tanto Vollmar quanto seus correligionários passaram a votar a favor do orçamento na Baviera a partir de 1894, atitude esta que foi repetidamente condenada por praticamente todos os Congressos do Partido Social-Democrata Alemão.

De fato, a ênfase na prática política imediata contribuiu consideravelmente para o triunfo eleitoral do partido nos anos seguintes à sua legalização. Por outro lado, deu início a um processo de fragmentação da social-democracia em correntes antagonistas, que culminaria em sua cisão, após a deflagração da Primeira Guerra Mundial.

Mas a defesa de um pragmatismo político legalista não foi característica exclusiva da facção parlamentar do partido. Outros grupos estiveram empenhados em promover reformas lentas e graduais através da formação de uma tendência eminentemente anti-revolucionária no interior do movimento social-democrata. Dentre estes podemos destacar o grupo constituído por líderes do movimento sindical, como Karl Legien, Robert Schmidt e Paul Umbreit.

Findo o período de repressão, também as organizações sindicais passaram a se ocupar com a redação de um novo programa. Após terem sido quase destruídas depois de 1874, no final da década de 1880 já demonstravam sinais de pronta recuperação. Assim, o número de trabalhadores filiados aos Sindicatos Livres, vinculados à social-democracia, em 1888 era de 90.000, em 1893 era de 294.000, em 1900 chegou a 680.000 e em 1914 o número era de 2,5 milhões de trabalhadores ${ }^{365}$. Contudo, sua incrível abrangência e desenvolvimento não foram acompanhados de uma equivalente disposição para agir. Ao contrário, quanto maior e melhor organizado o movimento sindical na Alemanha tornava-se, mais tímidas e cautelosas eram suas decisões ${ }^{366}$.

A expansão dos sindicatos e de seus quadros permanentes, a disputa interna pelo direcionamento dos recursos, a centralização das decisões no âmbito nacional e a preocupação

\footnotetext{
${ }^{363}$ Como por exemplo, leis protetoras do trabalho, direito de associação, regulação social de consórcios de negociantes, supressão de impostos de consumo, etc.

${ }^{364}$ Cole, 1959, p.261.

365 Gustafsson, 1975, p.21.

${ }^{366}$ Cabe lembrar que nesta época também os empregadores começaram a se organizar. Em 1890 foram criadas associações de empresários da indústria metalúrgica (Unternehmerverbände) e em 1903 foi criada a organização "Liga Central de Industriais Alemães", que gera duas grandes organizações: Hauptstelle deutscher Arbeitgeberverbände - para a indústria pesada e têxtil; Verein deutscher Arbeitgeberverbände - para indústrias leves (Schorske, 1972, p. 30).
} 
com o seu fortalecimento organizacional foram fatores importantes que influíram para a perda de radicalidade do movimento sindical e para a prevalência de uma visão reformista entre os seus dirigentes e grande parte de sua base. Deste modo, priorizava-se a tática de negociações coletivas em detrimento de abordagens mais diretas e agressivas, estimulando na militância a disciplina e a neutralidade política. ${ }^{367}$

A partir de 1890 os Sindicatos Livres criaram uma organização central própria aliada a um novo movimento cooperativo, ambos dissociados do Partido Social-Democrata. Em 1892 o Congresso Sindical, tendo à frente Karl Legien (como Presidente da Comissão Geral), passou a adotar oficialmente o princípio da neutralidade partidária, no intuito de reunir o maior número possível de trabalhadores oriundos das mais diversas facções políticas. $\mathrm{O}$ Congresso do SPD em 1893 acatou tal decisão, ratificando a independência dos Sindicatos Livres. Doravante, os sindicatos estariam isentos do cumprimento das designações do partido e do respeito aos seus princípios doutrinários. O desapego dos líderes sindicais em relação a princípios teóricos que embasassem sua prática política levou-os a aderirem a um instrumentalismo pragmático e reformista.

A autonomia dos sindicatos, no entanto, possibilitou o surgimento de divergências entre estes e o partido, que ocasionalmente levaram ao enfrentamento político de ambos, como ocorreu no início do século XX. Diante das bem-sucedidas greves gerais ocorridas em vários pontos da Europa com vistas à obtenção do sufrágio universal ou da liberdade de associação (como na Bélgica em 1902, Dinamarca e Suécia em 1903 e a Revolução de fevereiro na Rússia no mesmo ano), o congresso do partido em Iena aprovou, em 17 de setembro de 1905, a resolução de Bebel que admitia o uso da greve de massas como instrumento de luta, desde que fosse um meio de defesa contra ataques ao sufrágio universal ou ao direito de associação. Deste modo, a greve política seria utilizada nos casos em que fosse necessário salvaguardar o exercício do poder legitimamente adquirido.

Tendo em vista a grande mobilização popular provocada no exterior e em algumas regiões da Alemanha (como a greve dos trabalhadores das minas de carvão do Ruhr em janeiro de 1905), vários grupos do movimento operário alemão passaram a exercer pressão

\footnotetext{
${ }^{367}$ ELEY, Geof. Forjando a democracia: a história da esquerda na Europa, 1850-2000. São Paulo: Fundação Perseu Abramo, 2005, p.105.
} 
para a realização de grandes greves políticas de massas - principalmente nos Estados em que fossem privados os direitos políticos ao trabalhador ${ }^{368}$.

Entretanto, dirigentes sindicais reportaram-se, em 23 de setembro do mesmo ano, ao Congresso do Partido Social-Democrata de Mannheim para fazerem aprovar a resolução do Congresso Sindicalista de Colônia (de maio de 1905) que condenou a greve de massas, por ser um instrumento que geraria um desgaste político e financeiro prejudicial à organização. Assim, conseguiram implantar o reconhecimento da paridade entre Sindicatos Livres e o partido no tocante à tomada de posição a respeito das greves de massas, o que na prática possibilitou aos líderes sindicais frear os esforços implementados neste sentido.

Enquanto a ala reformista do partido e dos sindicatos, incluindo revisionistas e $\operatorname{ortodoxos}^{369}$, procuravam estabelecer limites à utilização da greve de massas, o grupo radical de esquerda, liderado na Alemanha por Rosa Luxemburg, saudou com entusiasmo os resultados obtidos na Rússia. Em artigo intitulado "Greve de massas, partido e sindicatos" ${ }^{370}$, escrito em 1906, Rosa defendeu o reexame dos objetivos e estratégias do partido, à luz das novas condições históricas e do desenvolvimento da luta de classes ${ }^{371}$.

Assim, Rosa endereçou contundentes críticas aos dirigentes sindicais responsáveis pela resolução do Congresso de Colônia - especialmente Robert Schmidt, Bömelburg e Leimpeters - que condenavam terminantemente a utilização da greve de massas. Segundo a autora, a estreiteza de visão e a mediocridade complacente dos líderes sindicais os impediriam de enxergar as novas condições da luta de classes, que inaugurariam uma nova época na história do movimento operário.

\footnotetext{
${ }^{368}$ Cabe lembrar que, em 1906, ocorreu uma ofensiva pela reintrodução do sufrágio universal na Saxônia (onde o sistema das três classes havia sido restaurado em 1896), em Hamburgo, Alsácia, Brunswick, Hessen e Prússia.

${ }^{369}$ No Congresso da Internacional de Stuttgart Bebel afirmou: "Creio que a greve e a insurreição militar são sacrifícios inúteis" (CARONE, Edgard. A II Internacional pelos seus congressos (1889-1914). São Paulo: Edusp, 1993, p. 94).

${ }^{370}$ LUXEMBURG, Rosa. Oeuvres I - Reforme ou révolution? Grève de masse, parti et syndicats. Paris: François Maspero, 1969.

${ }^{371}$ Convém ressaltar a mudança de posicionamento teórico de Kautsky em relação à greve de massas. Em artigo na Neue Zeit, de 11/3/1905, intitulado "As lições da greve dos mineiros" ele havia afirmado: "as grandes ações decisivas do batalhador proletariado será lutada através de vários tipos de greves políticas. E aqui a prática corre mais rapidamente do que a teoria. Por um tempo nós discutimos a greve política e procuramos sua formulação e justificação teórica, uma poderosa greve política de massas depois da outra incendiará por combustão espontânea das massas - cada greve de massas se torna uma ação política, cada grande teste político de força culmina na greve de massas (...)" (KAUTSKY, apud, LUXEMBURG, Rosa. "Theory and Practice”. In. www.marxists.org, 1910). Após 1907 Kautsky reformulará sua opinião, passando a considerar a greve política de massas inaplicável à Alemanha, sendo concebível somente como um evento único e definitivo, que envolvesse todo o proletariado organizado (Cf. KAUTSKY, "La revolución social”. In: Cuadernos de pasado y presente, n. 68. México, D.F: PYP, 1978).
} 
A seu ver, as greves de massas ocorridas na Rússia, consistiriam em um fenômeno histórico - resultante da atuação de uma multiplicidade de fatores econômicos, políticos, sociais, gerais e locais, materiais e psicológicos ${ }^{372}$-, isto é, uma nova forma de manifestação da luta de classes. Com efeito, nas palavras de Rosa Luxemburg, "na realidade não é a greve de massas que produz a revolução, mas a revolução que produz a greve de massas" ${ }^{\text {,73 }}$. Nestes termos, a greve de massas não seria um ato único; faria parte de todo um período de lutas de classe, ao longo do qual o movimento popular desenvolveria uma unidade e sentido, e seus membros, através da experiência, assumiriam uma consciência de classe ativa e concreta.

Assim, opondo-se à concepção rígida e mecânica da burocracia sindical e partidária, que somente admitiriam a luta como "o resultado de uma organização que chega a um certo grau de força”, Rosa afirma que a organização nasceria como produto da luta, não sendo necessário um movimento previamente organizado e educado ${ }^{374}$. Por conseguinte, anuncia que "não é a organização sozinha que fornece as tropas combatentes, mas a batalha que fornece, em grande medida, os recrutas para a organização",375.

Ao destacar a importância do elemento espontâneo e das massas desorganizadas, tanto no que se refere às ações diretas quanto à política parlamentar ${ }^{376}$, Rosa passa a atribuir um novo papel ${ }^{377}$ ao partido: em lugar de "fabricar" a revolução, deveria orientar politicamente a luta, fornecendo a palavra de ordem e uma tática socialista conseqüente e decidida, capaz de provocar nas massas um sentimento de segurança, confiança e combatividade ${ }^{378}$. O partido, portanto, deveria adaptar-se às condições da luta de classes, tornando-se porta-voz e intérprete da vontade das massas ${ }^{379}$.

Consoante o entendimento de Rosa, a exasperação do conflito de classes daria ensejo a uma situação revolucionária na qual a luta política e a luta econômica vincular-se-iam dialeticamente. A interação recíproca entre conflito político e conflito econômico seria

\footnotetext{
${ }^{372}$ Ibid, p. 135.

${ }^{373}$ Ibid, p. 134.

${ }^{374}$ Ibid, p. 146.

${ }^{375}$ Ibid, p. 147.

376 "Mesmo no plano parlamentar, o poder das luta de classes proletária não se apóia em um pequeno núcleo organizado, mas em uma vasta periferia do proletariado imbuída de simpatias revolucionárias. Se a socialdemocracia quiser vencer a batalha eleitoral unicamente com o apoio de algumas centenas de milhares de organizados, ela se condenará ao fracasso" (Ibid, p.147).

377 De acordo com Rosa, "a revolução faz entrar em cena massas populares tão volumosas que toda tentativa de regrar o avanço ou estimar os custos do movimento" apareceriam como uma atitude desesperada” (Ibid, p.136).

${ }^{378}$ Ibid, p. 137.

${ }^{379}$ Ibid, p.174;
} 
evidenciada pelo fato de que, durante o período revolucionário cada luta parcial ganha a dimensão de uma "explosão geral".

Os operários bruscamente eletrizados pela ação política reagem imediatamente no domínio que lhes é mais próximo: eles se sublevam contra sua condição de escravidão econômica. $\mathrm{O}$ gesto de revolta que é a luta política os faz sentir com uma intensidade desconhecida os pesos de suas cadeias econômicas ${ }^{380}$.

Deste modo, as greves de massas, nascidas de uma grande "fermentação revolucionária", conjugaria a batalha por objetivos econômicos e por objetivos políticos. As greves parciais teriam seu caráter transformado à medida que o instinto e sentimento de classe revolucionário aflorassem. Sendo assim, a tentativa de desvinculação entre luta econômica e luta política, realizada por dirigentes sindicais, seria frustrada.

Para Rosa, portanto, não haveria duas espécies distintas de lutas da classe operária uma de caráter político e outra de caráter econômico - mas sim uma única luta de classes que visa tanto limitar os efeitos da exploração capitalista quanto suprimir esta exploração ${ }^{381}$.

A completa unidade do movimento operário sindical e socialista, indispensável às futuras lutas de massas na Alemanha, já está realizada, ela está encarnada pela enorme massa que constitui ao mesmo tempo a base do partido socialista e a dos sindicatos; os dois aspectos do movimento operário estão confundidos em uma unidade espiritual que constitui a consciência da grande massa ${ }^{382}$.

Neste sentido, a distinção entre a luta política e a econômica seria um produto artificial do período parlamentar. Na realidade, ambas constituiriam duas fases, ou dois níveis da luta pela emancipação da classe trabalhadora, envolvendo a defesa de interesses imediatos e futuros comuns ao proletariado. Desta maneira, a "barreira artificial" elevada entre os sindicatos e a social-democracia seria superada no período revolucionário.

Rosa adverte, então, que a teoria da "igualdade de direitos" e a teoria da "ação paralela" - que apregoam a autonomia completa dos sindicatos em relação ao partido decorreriam de uma confusão teórica ou de uma incompreensão sobre o papel dos sindicatos na luta pelo socialismo. Tais equívocos e descaminhos, representados pelos clamores em favor do distanciamento entre sindicatos e social-democracia, exprimiriam, ainda, a propagação de uma tendência oportunista presente nas duas organizações, que pretenderia

\footnotetext{
${ }^{380}$ Ibid, p. 133.

${ }^{381}$ Ibid, p. 161.

${ }^{382}$ Ibid, p. 168.
} 
reduzir a luta política à luta parlamentar, transformando o caráter revolucionário da socialdemocracia em um caráter reformista pequeno-burguês.

Segundo Rosa, a força de atração dos Sindicatos Livres não residiria em sua aparência de neutralidade, mas, ao contrário, em seu caráter verdadeiramente socialista. Por conseguinte, todas as tentativas de desvinculação dos sindicatos de questões de ordem política seriam vãs - incluindo a condenação das paralisações do $1^{\circ}$ de maio ${ }^{383}$ - pois iriam de encontro com a própria natureza, instinto e sentimento do proletariado.

A seu ver, tal tendência oportunista seria fortalecida pela criação de uma casta de funcionários sindicais permanentes, responsáveis por atividades profissionais especializadas dentro do aparelho administrativo sindical. O "burocratismo" - produzido pelo crescimento dos sindicatos e pela fragmentação das lutas econômicas - seria caracterizado por uma estreiteza de visão e uma sobreestimação da organização, que passaria a ser vista como um fim em si mesma, isto é, "o bem supremo ao qual os interesses da luta devem se subordinar, ${ }^{384}$.

Esta propensão à hesitação, à moderação e à ênfase na luta sindical manifestar-se-ia igualmente dentro do partido, embora em menor proporção ${ }^{385}$. Imersos na luta cotidiana, os social-democratas acabariam aderindo a um "otimismo incondicional" que apontaria na direção de uma nova teoria e prática parlamentar e sindical, imbuídas de uma perspectiva ilimitada de progresso econômico sob o sistema capitalista. Assim, manifestariam considerável hostilidade em relação à crítica teórica e indiferença em relação ao objetivo final do movimento.

A crítica de Rosa à burocracia sindical e partidária foi posteriormente retomada por Max Weber e Robert Michels nas duas primeiras décadas do século XX, em suas análises sobre o SPD. Weber interpretava a burocratização dos partidos como uma consequiência do

\footnotetext{
383 A greve de $1^{\circ}$ de maio consistia em um ato simbólico - transformado em uma tradição do socialismo internacional - com vistas ao fortalecimento da consciência de classe e da solidariedade. A partir de 1905, no Congresso de Colônia, os dirigentes sindicais colocaram em xeque a greve no $1^{\circ}$ de Maio, advogando pela sua conversão em uma celebração pública após o fim da jornada de trabalho, ao invés de uma paralisação das atividades. Estes líderes defendiam que a paralisação somente fosse realizada onde houvesse tal possibilidade, visto que em 1905, 6.404 trabalhadores sofreram represálias após o $1^{\text {o }}$ de Maio, já em 1906 foram 32.000 (Schorske, 1972, p.91).

${ }^{384}$ Ibid, p. 169.

${ }^{385}$ Ibid, p. 171.
} 
mesmo processo inevitável em desenvolvimento no âmbito da sociedade em geral ${ }^{386}$ - seja na economia seja na administração pública.

De acordo com Weber, o crescimento em importância do funcionalismo assalariado, a expansão da máquina eleitoral destinada à obtenção de votos, a racionalização das técnicas de campanha política e a expansão organizacional suscitariam o avanço irresistível da burocratização partidária. Deste modo, alertava para o fato de que seria a "ditadura do funcionário", e não a do operário, que estaria em fase de ascensão ${ }^{387}$.

A medida em que a dominação do espírito burocrático se impõe - juntamente com a ênfase na disciplina, na arrecadação de fundos, na imprensa e na publicidade do partido ocorreria, igualmente, a centralização do poder e a cristalização de um estrato de privilegiados dentro da organização. Entrementes, a atividade dos membros seria restringida à colaboração e votação nas eleições ${ }^{388}$. Neste sentido, a construção de um aparelho burocrático partidário no SPD o teria transformado, de partido fundamentalmente ideológico (Weltanschauungspartei) - destinado a concretizar ideais políticos explícitos - em um partido para concessão de cargos, cujos objetivos voltam-se para a conquista dos principais postos políticos pelos líderes e o êxito na luta eleitoral ${ }^{389}$.

Assim, enquanto nos partidos o surgimento de líderes propiciaria o rompimento da solidariedade de classe e a perda do caráter ideológico, nos sindicatos - lócus de difusão de um "ethos heróico" de fraternidade - ocorreria a concentração nas lutas econômicas

\footnotetext{
386 "A democracia moderna, em cujo contexto os Estados Unidos são uma grande democracia estatal, irá transformar-se em uma democracia burocratizada. E tem que ser assim porque ela substitui os funcionários honorários provenientes da nobreza ou de outras classes por uma burocracia remunerada. $\mathrm{O}$ mesmo ocorre em toda parte,inclusive no âmbito dos partidos. É um processo inevitável, e a primeira coisa que também o socialismo deverá levar em consideração é esta realidade: a necessidade de uma prolongada preparação profissional, de uma especialização cada vez mais refinada e de uma direção nas mãos de uma burocracia profissional formada segundo esses critérios" (WEBER, Max. "Capitalismo e sociedade rural na Alemanha". In: Coleção Os pensadores. São Paulo: Abril Cultural, 1974, p.96).

${ }^{387}$ Ibid, p.113.

388 "As atividades dos membros são muito limitadas, geralmente não fazem mais que pagar suas contribuições, assinar o jornal do partido, comparecer com certa regularidade às assembléias onde oradores do partido se apresentam, e oferecer voluntariamente uma cota moderada de trabalho à época das eleições. Em troca, eles obtêm pelo menos participação formal na eleição do executivo local do partido e dos administradores (Vertravensmänner) e, dependendo do tamanho da localidade, obtêm também o direito de opinar direta ou indiretamente na seleção dos representantes às convenções do partido. Por via de regra, entretanto, todos os candidatos são designados pelo núcleo composto de líderes permanentes e burocratas. As mais das vezes estes candidatos são também recrutados dentre esses últimos, suplementados por alguns dignitários que são úteis e meritórios em virtude de seus nomes bem conhecidos, influência social pessoal ou sua presteza em fazer contribuições financeiras. (...) O eleitor comum, que não pertence a nenhuma organização e é cortejado pelos partidos, é completamente inativo; os partidos notam-no principalmente durante as eleições, de outra forma somente através da propaganda a ele dirigida" (Weber, 1974, p.74).

${ }^{389}$ WEBER, Max. "Parlamentarismo e governo numa Alemanha reconstruída: uma contribuição à crítica política do funcionalismo e da política partidária". In: Coleção Os pensadores. São Paulo: Abril Cultural, 1974, p.27.
} 
imediatas, em oposição a pretensões políticas. Desta maneira, paulatinamente ganhariam um caráter apolítico ou antipolítico ${ }^{390}$.

As tão grandiosas esperanças que o Manifesto Comunista depositara em uma derrubada da sociedade burguesa foram substituídas por expectativas muito mais modestas. Entre essas inclui-se a teoria de que o socialismo amadurece automaticamente no caminho da evolução, posto que a produção econômica "se socializa" de maneira crescente. ${ }^{391}$

O estudo realizado por Michels apontou no mesmo sentido, ao relacionar a expansão da burocracia à perda da substância revolucionária e à hegemonia de uma ideologia e orientação política pequeno-burguesas ${ }^{392}$. Na concepção do autor, a burocracia seria uma força conservadora dentro do partido. A divisão entre uma minoria dirigente e uma maioria dirigida e a diferenciação hierarquizada de órgãos e funções conduziriam a uma tendência aristocratizante. Por conseguinte, Michels conclui que quanto mais o aparelho de uma organização se complexifica, isto é, quanto mais ela vê aumentar o número de seus adeptos, seus fundos crescerem e sua imprensa desenvolver-se, mais terreno perde o governo diretamente exercido pela massa, suplantado pelo crescente poder dos comitês ${ }^{393}$.

Deste modo, a concentração do poder ${ }^{394}$ daria origem a uma "elite operária", uma oligarquia de "chefes profissionais" ${ }^{395}$ desprovidos de motivações idealistas. Outrossim, tais funcionários remunerados seriam orientados pela fidelidade, disciplina e sentimento de dever. Conforme se especializam em questões técnicas e pontuais, os dirigentes perderiam a perspectiva da totalidade.

Em nossos dias, o secretário de cada sindicato procura alistar em sua organização o maior número possível de adeptos,

\footnotetext{
${ }^{390}$ Ibid, p.56.

391 WEBER, Max. "Capitalismo e sociedade rural na Alemanha”. In: Coleção Os pensadores. São Paulo: Abril Cultural, 1974, p.113.

${ }^{392}$ MICHELS, Robert. Os partidos políticos. São Paulo: Senzala, [196-].

${ }^{393}$ Ibid, p. 15.

394 “A especialização técnica, essa conseqüência inevitável de toda organização mais ou menos extensa, torna necessária o que chamamos de direção dos negócios. Disso resulta que o poder de decisão, que é considerado como um dos atributos específicos da direção, é pouco a pouco retirado das massas e concentrado unicamente nas mãos dos chefes. E estes últimos, que no início não eram mais do que os órgãos executivos da vontade coletiva, não tardam em se tornar independentes da massa, subtraindo-se do seu controle" (Ibid, p. 15).

395 Michels ressalta a origem deste processo: "Nos primórdios do socialismo alemão, o homem de confiança, o Vertrauensmann, continuava a exercer sua profissão normal. Quando recebia algum pagamento este era dos mais modestos e concedido apenas a título temporário. Sua função não era, para ele, uma fonte de renda. $O$ empregado da organização era ainda o simples companheiro de trabalho de seus co-associados, participando do gênero de vida e da mesma condição social. Atualmente ele é quase sempre substituído pelo político profissional, o Berzirksleiter, etc. A medida que o partido moderno evolui para uma forma de organização mais sólida, vemos acentuar-se a tendência de substituir os chefes ocasionais pelos chefes profissionais" (Ibid, p.1718).
} 
aprofundar as sutilezas casuísticas dos seguros contra acidentes e invalidez, familiarizar-se com os problemas específicos da fiscalização do trabalho nas fábricas e da jurisdição arbitral, com o sistema de vales aplicado nas lojas das cooperativas e com o controle do consumo de gás na administração municipal. Mas à medida que os dirigentes se especializam nessas questões práticas, perdem a capacidade de apreender o conjunto do movimento operário, senão em sua totalidade, pelo menos em suas manifestações puramente sindicais. Quanto mais se entregam ao estudo de questões técnicas, menos tempo lhes resta, menos desejo e interesse pelo estudo dos grandes problemas da filosofia da história, tornando-se cada vez mais falsa sua maneira de julgar as questões internacionais. (...) $\mathrm{O}$ espírito burocrático rebaixa o caráter e engendra a indigência moral. Em toda burocracia, observa-se a caça aos empregos, a mania das promoções, a servilidade obsequiosa diante dos superiores e uma atitude arrogante para com os subordinados ${ }^{396}$.

Michels observa, portanto, a contradição presente no processo de expansão dos partidos socialistas. Quanto mais fortes e organizados se tornavam, mais subordinados estariam às "exigências efêmeras da vida cotidiana". Em suma, "aquilo que seu ângulo de visão ganhava em precisão, perdia em amplitude e grandeza"397. Como conseqüência, rejeitavam todas as críticas, mesmo quando feitas em nome dos princípios fundamentais do socialismo, a partir do momento em que ameaçavam enfraquecer a situação do grupo parlamentar $^{398}$.

Por esta razão, segundo Michels, inúmeros chefes socialistas teriam se tornado "estranhos àquilo que o socialismo contém de essencial, debatendo-se uns contra o ceticismo,

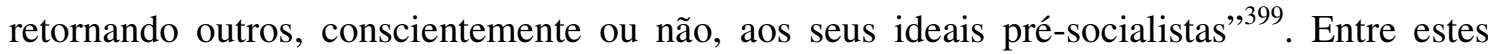
estariam os revisionistas, que permaneceriam apenas "exteriormente fiéis à causa a que um dia sacrificaram o melhor de si mesmos":

Renunciando, porém, ao idealismo, tornam-se oportunistas; os antigos crentes, os altruístas de antes, cujo ardoroso coração só aspirava a dar-se, transformaram-se em céticos, em egoístas cujas ações são guiadas apenas pelo cálculo frio. É certo que à medida que um indivíduo alcança em seu partido, posições cada vez mais elevadas, seu mundo psicológico e intelectual geralmente sofre uma evolução que termina em transformação completa. E quando essa transformação está concluída, o chefe não vê em sua modificação mais do que um reflexo da modificação operada, segundo pretende, no mundo que o

\footnotetext{
${ }^{396}$ Ibid, p. 105.

${ }^{397}$ Ibid, p. 104.

${ }^{398}$ Ibid, p. 85.

${ }^{399}$ Ibid, p. 119.
} 
envolve. As novas circunstâncias, diz ele, exigem uma nova teoria e impõem uma nova tática. 400

Para Michels, portanto, o reformismo e o revisionismo seriam fenômenos produzidos pela expansão e burocratização dos partidos, que, por sua vez, originariam uma elite dirigente pragmática, avessa ao idealismo e afastada das massas. Assim, de acordo com o autor, "é da necessidade psicológica de encontrar uma explicação e uma desculpa para a metamorfoses dos chefes que nasceu em grande parte a teoria reformista e revisionista do socialismo internacional" 401

De fato, se analisarmos o período de maior desenvolvimento das instituições do partido, de 1905 a 1909, veremos que coincide precisamente com o momento de avanço das forças reformistas ${ }^{402}$. Antes de 1905 a organização hierárquica e racional do partido existia apenas em forma embrionária. Os seus vários níveis de atuação - central, regional ou local ainda não estavam bem definidos e coordenados. Não havia um controle eficiente sobre o tamanho da organização e sua estrutura financeira, nem um sistema regular de troca de informações com as unidades locais.

Nesta época, a liderança nacional concentrava-se nas mãos dos parlamentares, únicos social-democratas que sob as leis anti-socialistas desfrutaram de certa imunidade. Embora o Comitê Diretor do partido fosse eleito por uma Assembléia Geral, a delegação parlamentar era sempre consultada na tomada de decisões.

Desde os fins dos anos 90, tal tendência ao centralismo foi colocada em xeque. Com o início da expansão do partido e a necessidade de estabelecer uma administração mais "eficiente" e sistemática, um grande aparato burocrático começou a ser erigido, formado por uma hierarquia estruturada de políticos profissionais. Desta forma, inúmeras reformulações foram incorporadas ao estatuto do partido ${ }^{403}$.

Paulatinamente o centralismo democrático vigente no partido teve que ceder em diversos pontos às tendências federalistas dos reformistas, que buscavam maior liberdade de ação nas organizações regionais. Em 1898, o Congresso de Stuttgart decidiu rever a resolução aprovada no ano anterior - no Congresso de Hamburgo - que embora delegasse às organizações locais a decisão em tomar parte nas eleições, as proibia de firmarem

\footnotetext{
${ }^{400}$ Ibid.

${ }^{401}$ Ibid.

${ }^{402}$ Cf. DROZ, Jacques. Histoire générale du socialisme - tomo II. Paris: Presses Universitaires de France, 1974.

${ }^{403}$ Contudo, já em 1892, no Congresso de Berlim do SPD foi levantada a preocupação com o crescimento do número de funcionários (Schorske, 1975, p.116-145).
} 
compromissos ou alianças com outros partidos. Assim, permitiu-se que as organizações locais realizassem alianças com partidos que se comprometessem a defender o sufrágio universal e a votar contra qualquer lei repressiva ${ }^{404}$.

Com efeito, como as condições de associação política variavam de Estado para Estado, cada grupo local estaria livre para se organizar da melhor forma possível sob as condições políticas que encontravam ${ }^{405}$. Quando, em 1899 , foi revogada a lei que proibia o partido de se organizar através das fronteiras dos Estados, a pressão para estabelecer maior uniformidade entre as unidades locais se elevou. Contudo, o Congresso de Hannover, do mesmo ano, consolidou a vitória dos chefes locais, defensores das alianças eleitorais, ao dispor:

O partido, a fim de atingir seu fim, emprega todos os meios que, estando em harmonia com seus princípios fundamentais, prometem êxito sem fazer nenhuma ilusão acerca da natureza e essência dos partidos burgueses como representantes e defensores da ordem política e social existente, não se nega, em determinados casos, a unir sua ação com alguns deles (grifo nosso), quer se trate de aumentar a força eleitoral do partido, de ampliar os direitos e liberdades do povo, de melhorar consideravelmente a situação social da classe trabalhadora, de fomentar o cumprimento dos deveres frente à civilização, ou de combater projetos hostis à classe operária ou ao povo. Assim, o partido conserva sempre em sua atuação sua completa autonomia e sua independência e considera cada êxito que tenha como um passo que o aproxima do seu objetivo final. $^{406}$

O Congresso de Mainz, de 1900, estabelecia mais um passo na direção da descentralização ao instituir uma separação de poderes administrativos e políticos na cúpula do partido, dividida em um Comitê Diretor (Parteivorstand) - composto por 2 presidentes, 2 secretários, 1 tesoureiro e 2 associados $^{407}$ - e uma Comissão de Controle, com 9 membros com poderes para revisar todas as ações do executivo. O Estatuto aprovado em 1900 deixava ainda aberta a forma de organização local e reafirmava a importância do líder local (Vertrauensmann), que, assim, tornava-se um representante oficial do partido na localidade ${ }^{408}$.

\footnotetext{
${ }^{404}$ Era o caso da Baviera, país católico e predominantemente campesino, onde os socialistas não esperavam obter a maioria. Assim, o Partido Social-Democrata bávaro se aliou com o Partido Católico do Centro.

405 A única instituição comum era o Vertrauensmann - um agente local eleito para manter contato entre a organização local e o Executivo do partido (Schorske, 1975, p.116-145).

${ }^{406}$ COLE, George Douglas Howard. Historia del pensamiento socialista: la segunda internacional: $1889-1914$. México: Fondo de Cultura Economica, v.1, 1959, p. 248.

${ }^{407}$ Entre 1904 e 1906 adicionou-se mais 3 secretários (Droz, 1974, p.33).

${ }^{408}$ Constituiu-se a tendência a fundir organizações locais (Ortsvereine) em organizações correspondentes aos distritos eleitorais (Wahlkreisvereine). No nível dos Estados começam a surgir organizações estaduais permanentes - principalmente nos Estados do sul, onde as leis eram mais liberais e a participação nas eleições
} 
Além da possibilidade de constituir alianças locais com outros partidos, a revisão dos limites à participação dos políticos nos Parlamentos estaduais (Landtags) também foi reivindicada. No Congresso de Lübeck, de 1901, foi adotado um projeto elaborado por Bebel que tornava admissível a participação dos social-democratas na votação do orçamento. Em seu pronunciamento, Bebel justificou sua posição alegando que "a conquista do poder político seria o objetivo principal que um movimento proletário consciente dos antagonismos de classe deve perseguir" ${ }^{\prime 409}$.

Embora as críticas por parte da ala esquerda do partido tenham levado à condenação das correntes revisionistas no Congresso de Dresden ${ }^{410}$, em 1903, sua força e influência já se mostravam evidentes no tocante à determinação da prática do partido. Assim, a reorganização visando o sucesso eleitoral inscrevia-se na ordem do dia.

A crescente importância conferida à atividade eleitoral na vida do partido deu ensejo a mais uma revisão do estatuto de organização do partido, aprovada em 1904, no Congresso de Iena. Neste, fica estabelecido que as unidades básicas do partido seriam distribuídas de acordo com os distritos eleitorais; ou seja, cada "célula" do partido corresponderia a uma circunscrição eleitoral, cabendo-lhe organizar os trabalhos das associações locais visando à disputa das eleições. As unidades locais, por sua vez, deveriam se reportar às organizações estaduais ou provinciais, fornecendo anualmente dados sobre filiação, condições financeiras, despesas, atividades desenvolvidas, etc. Finalmente, os funcionários das organizações estaduais responderiam diretamente ao Executivo ${ }^{411}$.

A limitação da liberdade financeira das organizações estaduais e a sua relativa dependência política - exceto no que se refere à votação do orçamento e à realização de alianças com partidos burgueses - preservou ainda, em grande medida, o poder do Executivo. Todavia, o distanciamento entre a direção central e as unidades locais, executoras das

melhor estabelecidas (Württemberg, Hesse, Baviera, Oldenburg, Mecklenburg, Schleswig-Holstein e AlsáciaLorena). Na Prússia e na Saxônia o desenvolvimento se deu após 1905 (Cf. Cole, 1959).

${ }^{409}$ Droz, 1974, p.31.

${ }^{410}$ A resolução aprovada em Dresden foi ratificada in totum pelo Congresso de Amsterdã, da Segunda Internacional, em 1904. Este dispunha: "O congresso condena de maneira a mais enérgica as tentativas revisionistas, tendendo a mudar nossa tática, comprovada e vitoriosa, baseada sobre a luta de classes, e a substituir a conquista do poder político e a intensa luta contra a burguesia, por uma política de concessão à ordem estabelecida. A conseqüência de tal tática revisionista seria fazer um partido, que pretende a transformação a mais rápida possível da sociedade burguesa em sociedade socialista - de um partido, por conseguinte, revolucionário, no melhor sentido da palavra - em um partido se contentando em reformar a sociedade burguesa" (CARONE, Edgard. A II Internacional pelos seus congressos (1889-1914). São Paulo: Edusp, 1993, p.75).

${ }^{411}$ Cf. Cole, 1959. 
decisões do partido, favoreceu a desaparição de discussões de cunho teórico e político mais aprofundado nestas instituições. Ademais, a proliferação, a nível local, de funcionários e secretários empenhados em tarefas imediatas, como a ampliação do número de membros e a administração de órgãos do partido, acentuou a moderação e a apatia política, culminando no fortalecimento da ala direitista do partido ${ }^{412}$. Como aduz Bo Gustafsson,

a camada de funcionários do partido formava uma base para o revisionismo. É seguro que os funcionários eram receptivos a respeito destas idéias. O revisionismo se distanciava de transformações revolucionárias e colocava, em seu lugar, o trabalho prático diário no Parlamento, municipalidades, sindicatos e cooperativas de consumo em primeiro plano ${ }^{413}$.

Deste modo, o autor relaciona a postura conservadora dos funcionários a atributos inerentes ao desempenho de sua atividade profissional, além de ressaltar a tendência a priorizar a defesa de seus interesses privados e a preservação de seu cargo e posição dentro do aparelho do partido, em detrimento da causa proletária. Como resultado, passariam psicologicamente e economicamente para a pequena-burguesia.

Outro fator relevante que contribuiu para acentuar o caráter reformista do partido consistiu na sub-representação das médias e grandes cidades nos congressos. Antes das leis anti-socialistas toda organização local poderia enviar quantos delegados desejasse aos congressos do partido. Porém, a partir de 1891 foi fixado o número de três representantes por cada distrito eleitoral, reproduzindo, deste modo, a obsolescência presente na distribuição eleitoral do Reich. Mesmo com a mudança deste sistema de representação partidária, em 1909, e a adoção do princípio da proporcionalidade ${ }^{414}$, a sobre-representação dos pequenos distritos se manteve.

Como foi visto, a organização partidária e sindical teve um impressionante crescimento ao longo da última década do século XIX e primeiras décadas do século XX, não somente em termos de número de adesões ${ }^{415}$, mas em relação à sua estrutura organizacional. Devido à sua força e extensão, o Partido Social-Democrata tornou-se um modelo para outros partidos socialistas da Europa.

\footnotetext{
${ }^{412}$ Segundo Bo Gustafsson, entre 1900 e 1914 triplicou a proporção de funcionários do partido em relação ao número de militantes (Gustafsson, 1975, p.31).

${ }^{413}$ Gustafsson, 1975, p.32.

${ }^{414}$ Segundo este sistema, os distritos eleitorais com menos de 1.500 membros teriam direito a 1 delegado, os de até 3.000 teriam 2 delegados, os até 6.000 teriam 3 delegados, os de até 12.000, 4 delegados, os de até 18.000, 5 delegados e os acima de 18.000 teriam 6 delegados (Droz, 1974, p.33).

${ }^{415}$ Em 1906 o SPD reunia 384.000 membros, já em 1914 ele passa a abrigar mais de 1.000 .000 de filiados (Gustafsson, 1975).
} 
Não obstante seus numerosos méritos ${ }^{416}$, a expansão do partido e a criação de um eficiente aparelho burocrático levaram à predominância do elemento pequeno-burguês ${ }^{417}$ tanto entre funcionários, líderes e delegados do partido como em sua bancada parlamentar. Nestes termos, a organização em si passou a constituir uma barreira à ação revolucionária da classe operária, na medida em que o seu funcionamento - e a preservação dos cargos ocupados no partido, no parlamento ou nos sindicatos - dependia da moderação política das massas e da sua acomodação às restrições impostas pelo sistema parlamentar.

A atuação dentro dos limites institucionais da sociedade burguesa, seja através da política parlamentarista seja da ação sindical, conduziu, portanto, à submissão à Realpolitik, à sobrevalorização da via legalista e à renúncia dos objetivos emancipatórios socialistas. As melhorias conquistadas pelo movimento social-democrata no período de expansão do capitalismo eram vistas, então, como sinais de que a política reformista permitiria à classe trabalhadora galgar patamares cada vez mais altos de renda. Assim, passavam a identificar seus interesses com a manutenção do sistema econômico vigente.

Neste sentido, o êxito do movimento trouxe consigo elementos de sua própria destruição. A ênfase na satisfação dos interesses parciais imediatos gerou o enfraquecimento da luta de classes e a ilusão acerca da necessidade de conservação das bases da sociedade capitalista. Por conseguinte, conforme nos explica Mészáros, a refutação da luta de classes levou a social-democracia a negar a própria base de sua existência: a sua consciência e solidariedade de classe ${ }^{418}$.

O surgimento de uma corrente abertamente revisionista - consolidada a partir da elaboração teórica de Eduard Bernstein - cuja pretensão principal residia na reformulação da doutrina do partido a fim de atender aos propósitos práticos e demandas imediatas, conferiu maior força e coesão aos reformistas. No capítulo seguinte pretendemos analisar mais detidamente esta corrente que logrou reunir, em um curto espaço de tempo, uma grande quantidade de adeptos dentro do partido.

\footnotetext{
${ }^{416}$ Consoante observou Jacques Droz, A organização do partido apresenta incontestáveis méritos que a tornaram um modelo para numerosas nações. Com efeito, ele oferece o exemplo mais perfeito de livre discussão, de controle e de crítica, não tolera nenhuma obediência cega a uma "personalidade" qualquer, deixa a cada militante a possibilidade de fazer ouvir sua voz, enquanto ao mesmo tempo obriga a minoria a respeitar as decisões da maioria, uma vez que a discussão esteja fechada, criando por consequiência entre seus membros um cimento moral e uma disciplina consentida que se revela indestrutível (Droz, 1974, p.33).

${ }^{417}$ Em 1911, apenas $10 \%$ dos participantes do Congresso de Iena eram trabalhadores (Gustafsson, 1975, p.32).

${ }^{418}$ MÉSZÁROS, István. O poder da ideologia. São Paulo: Boitempo, 2004, p.433.
} 


\section{3- Eduard Bernstein e a Social-Democracia}

\section{1- A trajetória política de Bernstein}

Se desde o seu aparecimento o Partido Social Democrata Alemão manifestava uma forte tendência interna à fragmentação, ao longo da última década do século XIX inúmeros esforços foram realizados no sentido de alterar o programa político do partido e sua orientação para a ação prática. O revisionismo teórico surgiu, assim, de forma difusa na social-democracia, sendo antes um agregado de vozes dissonantes do que um movimento único e coerente.

Entre as diversas personalidades do partido que ganharam destaque na controvérsia podemos encontrar jornalistas, editores, parlamentares, sindicalistas e secretários do SPD como, por exemplo, Eduard David, Joseph Bloch, Adolph von Elm, Edmund Fischer, Paul Kampffmeyer, Paul Löbe, Heinrich Peus e Robert Schmid. Dedicados à tarefa de desatrelar a tática dos princípios "arcaicos" aos quais estava ancorada, procuraram fornecer, cada um a seu modo, fundamentos teóricos para a revisão da interpretação oficial da obra de Marx e Engels, predominante no partido.

Ironicamente, foi na pessoa de um dos mais proeminentes líderes do partido e excolaborador de Engels que o revisionismo encontrou seu legítimo porta-voz. Eduard Bernstein ganhou notoriedade por conferir coesão e força ao grupo revisionista através da organização e síntese de suas principais teses. Embora não representasse a única referência entre seus adeptos, seu nome passou a ser concebido como sinônimo desta orientação, sendo ora aplaudido ora execrado entre os membros da tradição socialista.

Sua trajetória política peculiar de certa forma espelha o movimento percorrido pelo próprio Partido Social-Democrata, que paulatinamente transitou de uma posição revolucionária para uma posição assumidamente reformista - cujo referencial teórico deslocara-se da perspectiva marxista para a liberal-democrática. Neste sentido, para compreendermos as origens e o desenvolvimento do fenômeno revisionista é oportuno recorrermos à análise do próprio percurso pessoal de Bernstein ${ }^{419}$, desde sua filiação ao partido até sua participação no governo republicano.

\footnotetext{
${ }^{419}$ Para uma exposição minuciosa da vida de Bernstein, veja: STEGER, Manfred B. The quest for evolutionary socialism. New York: Cambridge Press, 1997; GAY, Peter. The dilemma of democratic socialism. New York: Columbia University Press, 1970; e sua autobiografia "My Years of Exile: Reminiscences of a Socialist (1915/1921)", In: <www.marxists.org>, publicada em 1915.
} 
Eduard Bernstein nasceu em 6 de janeiro de 1850, no seio de uma família judia de Berlim. Seu pai, Jakob Bernstein, era maquinista ferroviário, tendo enfrentado muitas dificuldades para garantir o sustento de seus sete filhos. No intuito de contribuir na renda familiar, aos dezesseis anos Bernstein abandonou o curso ginasial e adquiriu um emprego como assistente em um banco. Seu tio Aaron Bernstein era um jornalista liberal, editor da "Berliner Volkszeitung", fato que o incentivou a prosseguir seus estudos em História e Filosofia na qualidade de autodidata.

Seu interesse pela política manifestou-se inicialmente em virtude da Guerra FrancoPrussiana de 1870, quando constituiu um pequeno grupo de discussões filosóficas denominado "Utopia". Embora ainda não tivesse estabelecido contato com a doutrina socialista, Bernstein - que se opunha à propaganda nacionalista difundida pelo governo identificou-se com as posições assumidas por Wilhelm Liebknecht e August Bebel, que na ocasião enfrentavam um julgamento por alta traição devido a suas declarações contrárias à guerra e à anexação da Alsácia e Lorena. A forte convicção ética e a perspectiva internacionalista destes homens despertaram a atenção de Bernstein para a literatura socialista, principalmente os escritos de Ferdinand Lassalle ${ }^{420}$, Eugen Dühring ${ }^{421}$ e Karl $\operatorname{Marx}^{422}$.

Em fevereiro de 1872, Bernstein filiou-se ao Partido Social-Democrata dos Trabalhadores Alemães, entrando em contato direto com Bebel, Ignaz Auer e outros membros importantes do partido. Sua atuação partidária e militante colocou-o rapidamente em evidência, sendo eleito para participar do Congresso de Gotha de 1875, onde foi aprovado o novo programa do partido que consagrava a sua unificação com a Associação Geral dos Trabalhadores Alemães. Bernstein saudou a unificação dos partidos, alertando, no entanto, que tal empreendimento exigiria que fossem feitas concessões práticas e teóricas aos

\footnotetext{
420 "Herr Bastiat Schulze von Delitzsch".

421 "Kritische Geschichte der Nationalökonomie und des Sozialismus" e "Cursus der National und Sozialökonomie".

422 "Mensagem à Liga dos Comunistas" e "A guerra civil na França".
} 
$\operatorname{lassalleanos}^{423}$. Na realidade, o próprio autor possuía grande admiração por Lassalle, cuja memória era amplamente reverenciada entre os socialistas alemães da época ${ }^{424}$.

Durante seus primeiros anos no partido, Bernstein demonstrava igualmente grande simpatia pela obra de Dühring ${ }^{425}$, principalmente seu "Curso de Economia Social e Nacional”, tendo enviado cópias da publicação a vários líderes social-democratas, como Bracke, Fritzsche, Most e Bebel. Neste período o ecletismo liberal e ético de Dühring arregimentara grandes segmentos da social-democracia, o que motivou Engels a rebatê-lo em uma série de artigos no Vorwärts, entre 1877 e $1878^{426}$. Com efeito, a despeito de seu espírito eclético, o ambíguo posicionamento político de Bernstein permanecia eclipsado pelo sectarismo e pela falta de unidade teórica vigente dentro do novo partido. Seu viés teórico reformista, no entanto, não demoraria a despertar a atenção dos líderes social-democratas filiados à tradição marxista.

Em 1878, por ocasião da promulgação das leis anti-socialistas, Bernstein aceitara o convite para ocupar o cargo de secretário particular de Karl Höchberg ${ }^{427}$, simpatizante da social-democracia com quem havia fundado um grupo de discussão denominado Mohren $C l u b^{428}$. Deste modo, Bernstein emigrou para Lugano, Suíça, a fim de auxiliar na editoração do jornal "Die Zunkunft". Tal periódico ${ }^{429}$, marcado por discussões teóricas de cunho idealista, foi proibido pelas autoridades suíças, levando Höchberg a mudar seu centro de operações para Zurique em 1879, onde prosseguiu seu trabalho de difusão de material e propaganda pró-socialista.

\footnotetext{
${ }^{423}$ Em carta de Bernstein a Bebel, de 19 de janeiro de 1875, este afirma: "Eu não sei como você se sente quanto à fusão, mas eu acredito que nós concordamos que a idéia de unidade deve ser mantida o quanto for possível. Eu não possuo ilusões, mas sei que a necessidade de unidade é também muito sentida entre os membros do Verein. Infelizmente, estas pessoas são lassalleanos tão intransigentes que nós teremos que fazer concessões a este respeito" (Bernstein apud Gay, 1970, p.36).

${ }^{424}$ Isto apenas começaria a ser revisto com a publicação da "Crítica ao Programa de Gotha”, na qual Marx dirige sérias críticas ao posicionamento lassalleano.

${ }^{425}$ Peter Gay (1970, p.103) apresenta a seguinte declaração de Bernstein, escrita no final de sua vida: "Não apreciava Dühring como pessoa, mas como um socialista que tinha, em minha opinião, complementado (ou, pode-se dizer, continuado) Marx de maneira mais radical do que qualquer outro. Chame isto de ecletismo ou o que for, mas eu sinto que o movimento socialista é amplo o bastante para conter um Marx e um Dühring ao mesmo tempo (...) o que me agradava em Dühring era sua forte ênfase no elemento liberal do socialismo".

${ }^{426}$ Posteriormente conhecidos sob o nome de "Anti-Dühring".

${ }^{427}$ Karl Höchberg era filho de um banqueiro. Sua perspectiva ética e idealista sofria influência de Lange, Kant e Darwin, além dos economistas próximos aos socialistas de cátedra (Schramm, Rodbertus e Albert Schäffle). Cf. Gay, 1970, p.42-59.

${ }^{428}$ Deste grupo surgiu um projeto para educação de adultos, com escolas noturnas para trabalhadores. Cf..GAY, Peter. The dilemma of democratic socialism. New York: Columbia University Press, 1970, p.39.

${ }^{429}$ Fundado em Zurique, em 1877.
} 
Neste ínterim, Bernstein entrara em contato com o "Anti-Dühring" de Engels, cujo impacto lhe infundira maior entusiasmo com a teoria marxista. Contudo, sua tentativa inicial de aproximação com Marx e Engels foi frustrada. Em 13 de junho de 1879, Bernstein escreveu a Engels requerendo a sua aprovação para a publicação de uma nova revista socialreformista sob a direção de Höchberg - os "Anais de Ciência Social e Política Social”430 _ cujo primeiro exemplar trazia um polêmico artigo de crítica ao Partido Social-Democrata, intitulado "Exame retrospectivo do movimento socialista na Alemanha"431.

O artigo listava os erros cometidos pela social-democracia alemã, particularmente sua recusa a manter relações com as classes liberais burguesas e sua insistência na preservação do caráter proletário do partido. Segundo o artigo, o Partido Social-Democrata deveria realizar uma propaganda enérgica no seio da burguesia, substituindo os objetivos de longo alcance que assustam e afugentam a burguesia - pelas reformas pequeno-burguesas. Com isso, a "catástrofe final" transformar-se-ia num processo de decomposição realizado lentamente e, na medida do possível, de maneira pacífica ${ }^{432}$.

Consoante o artigo, o SPD deveria reunir em torno de si "todas as pessoas de sentimentos verdadeiramente humanitários". Para tanto seria imperativo que o partido renunciasse às "grosseiras paixões proletárias" e se colocasse sob a direção de burgueses cultos que, guiados por sentimentos filantrópicos, possibilitassem às massas populares "adquirir gostos refinados" e "aprender boas maneiras". Assim, não tardariam a aparecer numerosos partidários procedentes das classes cultas e ricas - justamente os elementos que deveriam ser atraídos para que a propaganda social-democrata atingisse êxitos tangíveis:

O socialismo alemão atribuiu demasiada importância à conquista das massas ao mesmo tempo que se descuidou da propaganda enérgica entre as chamadas camadas altas da sociedade, pois faltam ainda ao partido pessoas que possam representá-lo no Parlamento, sendo desejável e mesmo necessário que os mandatos sejam entregues a pessoas que já tiveram tempo e possibilidades para estudar a fundo os problemas. Os simples operários e os pequenos artesãos (...) só excepcionalmente podem dispor dos lazeres necessários para isso $^{433}$.

\footnotetext{
430 "Jahrbuch für Sozialwissenschaft und Sozialpolitik".

431 "Rückblicke auf die sozialistische Bewegung in Deutschland".

432 "Rückblicke auf die sozialistische Bewegung in Deutschland" apud MARX; ENGELS. Obras escolhidas. São Paulo: Alfa-Omega, v.3, 1980, p.276-282.

433 "Rückblicke auf die sozialistische Bewegung in Deutschland" apud MARX; ENGELS. Obras escolhidas. São Paulo: Alfa-Omega, v.3, 1980, p. 277.
} 
Por conseguinte, o partido deveria, através de uma atitude "melancólica e humilde", provar sua renúncia definitiva "aos despropósitos e aos exageros" que deram margem à promulgação da lei contra os socialistas. Com isto deveria acabar com todo o temor de um desenlace inevitável da moderna luta de classes, que intensificaria o ódio da burguesia em relação à social-democracia. $\mathrm{O}$ artigo, deste modo, apelava para o abandono da luta de classes a fim de que a burguesia - e com ela "todas as pessoas independentes" - não mais temesse marchar de mãos dadas com o proletariado. Outrossim, a via legal e pacífica deveria ser priorizada no movimento, que, embora mantivesse intacto seu programa, deveria adiar por tempo indefinido a realização de suas metas de longo prazo:

Precisamente agora, sob a pressão da lei contra os socialistas, o partido demonstra que não tem a intenção de recorrer à violência e de marchar para uma revolução sangrenta, mas ao contrário, está disposto (...) a seguir o caminho da legalidade, isto é, o caminho das reformas [grifo nosso]. Deste modo, se 500 ou 600 mil eleitores social-democratas (...) dispersos, além de tudo, por todo o país, se mostram suficientemente sensatos para não bater com a cabeça na parede e não se lançar, na proporção de 1 contra 10, a uma "revolução sangrenta", isso prova que renunciaram para sempre a utilizar qualquer acontecimento importante da política exterior e o ascenso revolucionário que dele decorra e mesmo a vitória alcançada pelo povo no conflito que, nesta base, se possa produzir. Se Berlim voltar algum dia a dar prova de sua incultura, com outro 18 de março [1848], a social-democracia não tomará parte na luta, como qualquer chusma ansiosa por lançar-se às barricadas (...) Quanto mais sereno, objetivo e circunspecto for ele [o partido] em sua crítica da ordem vigente e em suas propostas para reformá-la, menos possibilidades haverá para que se repita a manobra que agora teve êxito [com a promulgação das leis contra os socialistas] e graças a qual a reação consciente conseguiu pôr em suas mãos a burguesia, assustada com o fantasma vermelho ${ }^{434}$

$\mathrm{O}$ artigo enviado por Bernstein provocou a ira de Marx e Engels, que rapidamente elaboraram uma carta circular, datada de 17 de setembro de 1879, dirigida a Bebel, Liebknecht e Bracke. Nesta resposta, os autores manifestavam profunda preocupação com o que identificaram como um fenômeno inevitável: a incorporação de elementos oriundos da classe dominante ao movimento socialista - o que já fora mencionado no Manifesto do Partido Comunista, no capítulo “O socialismo alemão ou o ‘verdadeiro' socialismo”. Estes elementos exteriores à classe operária defenderiam a submissão do proletariado aos desígnios

434 "Rückblicke auf die sozialistische Bewegung in Deutschland", p.88, apud MARX; ENGELS. Obras escolhidas. São Paulo: Alfa-Omega, v.3, 1980, p. 278. 
das classes burguesas, vistas como intelectual e moralmente superiores, o que significaria nada menos do que a renúncia ao caráter de classe e ao projeto revolucionário de emancipação das classes trabalhadoras:

Tal é o programa dos três censores de Zurique. É de uma clareza meridiana, sobretudo para nós que, desde 1848, conhecemos na ponta da língua todas essas teses. Trata-se de representantes da pequena burguesia, acovardados ante a idéia de que os proletários, impelidos por sua posição revolucionária, possam "ir demasiado longe". Em lugar de uma oposição política resoluta, a conciliação geral; em lugar da luta contra o governo e a burguesia, as tentativas de convencê-los e atraí-los; em vez de uma resistência encarniçada às perseguições vindas de cima, a submissão humilde e o reconhecimento de que o castigo foi merecido. Todos os conflitos impostos pela necessidade histórica são interpretados como mal-entendidos; e dá-se uma saída comum a todas as discussões, com a declaração de que, no fundamental, todos estamos de acordo ${ }^{435}$.

Para Marx e Engels, portanto, as afirmações contidas no artigo revelariam a ingerência de uma ideologia burguesa e pequeno-burguesa na social-democracia, cuja preocupação central consistiria em esfumar, diluir e debilitar a luta de classes. Seu apreço pela república democrática, pela filantropia e pelo estabelecimento de alianças e compromissos com as classes dominantes expressaria uma tentativa vã de conciliar algumas idéias socialistas superficialmente assimiladas com os conceitos políticos mais díspares.

A confusão teórica provocada pelos autores do artigo resultaria, assim, de um esforço precipitado de adaptar a teoria no intuito de construir às pressas uma ciência particular. Em resumo, ao invés de aprofundarem-se, antes de tudo, no estudo da nova ciência marxista e procurarem esclarecer seus pontos fundamentais, provocaram uma confusão espantosa que, por sorte, teria ficado circunscrita quase exclusivamente a eles mesmos.

Diante do evidente conflito entre a orientação política dos autores do artigo e os princípios vigentes na social-democracia, Marx e Engels propuseram a desvinculação partidária destes senhores, de maneira a evitar que a direção do partido caísse nas mãos de homens com este perfil. Segundo os dois socialistas, o partido cometeria uma "traição contra si mesmo" se deixasse que ingressassem em suas fileiras e ocupassem postos de comando homens que, em 1848 e 1849, "levados pelo medo de toda e qualquer atividade, freavam a cada passo o movimento e acabaram por conduzi-lo à derrota; os mesmos que nunca desconfiam da reação e ficam extraordinariamente assombrados quando se vêem num beco

${ }^{435}$ MARX; ENGELS. Obras escolhidas. São Paulo: Alfa-Omega, v.3, 1980, p.279-280. 
sem saída, onde a resistência e a fuga são igualmente impossíveis; são os mesmos que se empenham em aprisionar a história em seu horizonte estreito de filisteus" ${ }^{\natural 36}$ :

Esses senhores, no entanto, como já foi exposto, estão encharcados de idéias burguesas e pequeno-burguesas, que se justificam sem dúvida num país tão pequeno-burguês quanto a Alemanha, mas tão-somente fora do partido operário socialdemocrata. Se esses senhores se agruparem num partido socialdemocrata pequeno-burguês, estarão em seu pleno direito; neste caso, poderíamos entabular negociações, formar com eles uma frente, em determinados momentos, etc. Dentro de um partido operário, no entanto, constituem um elemento de falsificação [grifo nosso]. Se, por enquanto, as circunstâncias aconselham que os toleremos, é necessário compreender que a ruptura com eles é apenas uma questão de tempo, e que devemos apenas tolerá-los, sem permitir que exerçam influência sobre a direção do partido $^{437}$.

Embora o artigo encaminhado por Bernstein e rejeitado por Marx, Engels, Liebknecht e Bebel não estivesse assinado, as contundentes críticas expressas na carta circular foram claramente endereçadas a Höchberg, Bernstein e Lübeck, a quem Engels atribuiu sua autoria $^{438}$. No entanto, de acordo com Peter Gay, o "Manifesto dos três de Zurique", como ficou conhecido, fora na verdade escrito pelo reformista Karl Flesch, com a ajuda de Höchberg e Schramm, tendo contado apenas com uma pequena colaboração de Bernstein ${ }^{439}$.

Não obstante a reduzida participação de Bernstein na redação do "infame" artigo restrita à inclusão de alguns pequenos trechos ao texto final - a influência das idéias de Höchberg em sua formação política não deve ser menosprezada. Sua inclinação ao neokantismo, encarnado na figura de Friedrich Albert Lange, e sua crença na democracia liberal, tão presente entre os socialistas de cátedra (Kathedersozialismus), marcaram-no profundamente. Por incentivo de Höchberg, Bernstein aprofundou seus estudos teóricos calcando-se nas idéias reformistas de Lujo Brentano, Gerhard Schulze-Gävernitz, Gustav Schmoller, Heinrich Herkner, Arthur Salz e Werner Sombart, os quais tentavam conciliar socialismo e liberalismo mediante a defesa da expansão da legislação social e da implementação de reformas graduais.

\footnotetext{
${ }^{436}$ Ibid, p. 280.

${ }^{437}$ MARX; ENGELS. Obras escolhidas. São Paulo: Alfa-Omega, v.3, 1980, p.281-282.

${ }^{438}$ De acordo com Peter Gay (1970, p.44), Bebel atribuiu a autoria a Höchberg, Schramm e Bernstein.

${ }^{439}$ Gay, 1970, p.44.
} 
Oscilando entre posições liberais e conservadoras, estes intelectuais "acomodacionistas" 440 - ou "modernistas" - pretendiam formular uma crítica à política classista de interesses e, ao mesmo tempo, remediar os males do sistema capitalista através de reformas sociais moderadas. Esta parte da elite culta alemã ${ }^{441}$, reunida em torno da Associação de Política Social ${ }^{442}$ (Verein für Sozialpolitik) - criada em 1872 -, aspirava à harmonia social e à resolução de todos os conflitos sociais, principalmente os de classe, mediante a implementação das seguintes propostas: criação de um seguro social, aprovação de leis sobre a inspeção de fábricas, ampliação da auto-gestão local, redução dos privilégios jurídicos e administrativos da aristocracia, estatização das ferrovias, revisão do sistema tributário e adoção de impostos com taxas progressivas, normatização do salário mínimo, formulação de programas limitados de obras públicas e instituição de acordos coletivos entre empregados e empregadores.

Assim, conforme observa Ringer, os socialistas de cátedra consideravam-se acima da luta de classes e fora do quadro do sistema partidário convencional - não obstante sua maior aproximação com os partidos burgueses, particularmente o Partido Nacional Liberal e o Partido Progressista. Repudiavam os interesses econômicos de classe e o utilitarismo, clamando pelo rejuvenescimento ético da vida política em nome do bem-estar da "totalidade" nacional. Deste modo, viam como tarefa sua o convencimento das massas, dos homens de negócios e de seus partidos à prática de uma política "idealista” que gerasse harmonia social e fosse guiada por objetivos culturais e éticos atrelados ao ideal da "Grande Alemanha" - o que exigiria a reconfiguração das forças políticas no cenário mundial ${ }^{443}$.

\footnotetext{
${ }^{440}$ Cf. RINGER, Fritz K. O declínio dos mandarins alemães: a comunidade acadêmica alemã, 1890-1933. São Paulo: Edusp, 2000.

${ }^{441}$ Cabe ressaltar que, de acordo com Ringer, “em 1890, a maioria dos professores e eruditos alemães aprovavam a tradicional estratificação de sua sociedade, toleravam os aspectos pouco liberais do regime político vigente e copmpartilhavam o medo e a hostilidade com que as classes dominantes enfrentavam o movimento socialdemocrata" (Ringer, 2000, p.130).

${ }^{442} \mathrm{O}$ grupo, composto por economistas e cientistas sociais, tinha como objetivo estimular as discussões acadêmicas e técnicas sobre os problemas econômicos e sociais da época, além de exercer uma influência sobre a orientação política do governo e a opinião pública. Criticavam as análises atemporais e ahistóricas, que procuravam atribuir aos homens uma natureza particular (tal como a concepção de homem econômico, oriunda da escola clássica inglesa). Enfatizavam ainda a importância da investigação empírica dos aspectos da vida sócio-econômica e instituições sociais; assim, as generalizações deviam basear-se em observações meticulosas das condições reais de produção e comércio, e não em abstrações e leis gerais sobre a natureza humana (Cf. Ringer, 2000, cap.3).

${ }^{443}$ Esta ênfase nos sentimentos nacionais levou muitos socialistas de cátedra a tornarem-se propagandistas da “causa nacional" e da "expansão colonial” (Ringer, 2000, p.134).
} 
Por conseguinte, a doutrina "social-liberal"444 defendida pelos socialistas de cátedra aderia à defesa de corretivos ao sistema de produção e distribuição com vistas à conciliação nacional e à paz social. Embora considerassem o processo de industrialização e de democratização como irreversíveis, apostavam na possibilidade de acomodação parcial às necessidades e condições modernas e no ajuste do organismo político e social às mudanças sócio-econômicas. Deste modo, em sua concepção, "uma sábia transformação das 'instituições culturais e políticas obsoletas', ajudaria a preservar 'os aspectos sadios e vitais' da antiga ordem social" "445. Logo, diante do "perigo" representado pelo crescimento da socialdemocracia, os acadêmicos alemães veriam uma alternativa intermediária entre a estagnação e a revolução: a conquista dos trabalhadores para o regime vigente, o aumento da influência do governo na solução das disputas industriais e a conversão dos sindicatos em auxiliares inócuos da política social-burocrática ${ }^{446}$. Por meio destas mudanças esperavam orientar as forças sociais e políticas emergentes da Revolução Industrial, afastando os operários do radicalismo social-democrata e do internacionalismo da ortodoxia marxista, inculcando-lhes um respeito mínimo pelas tradições culturais e pelos ideais nacionais ${ }^{447}$.

Evidentemente a maior parte dos líderes da social-democracia não se mostrava receptiva ao discurso reformista propagado pela intelectualidade alemã, reagindo ora com indiferença, ora com profunda desconfiança ${ }^{448}$. No entender de Engels, tais assertivas estariam pautadas em um socialismo burguês ou pequeno-burguês, satisfazendo-se com simples remendos à ordem societária que teriam por escopo abrandar o potencial conflitivo do sistema sem, no entanto, alterar-lhe a estrutura. Ainda de acordo com Engels, esta tendência pequeno-burguesa manifestar-se-ia inclusive dentro do próprio Partido Social-Democrata, expressa particularmente na fração que compunha o Reichstag. Conquanto reconhecessem a exatidão dos conceitos fundamentais do socialismo moderno e a imprescindibilidade de todos

\footnotetext{
444 Alcunhada por Ignaz Jastrow em seu artigo de 1894 "Sozialliberal: Die Aufgaben des Liberalismus in Preussen" (Ringer, 2000, p.148).

445 Ibid. p. 131.

${ }^{446}$ Ibid. p. 147-148.

${ }^{447}$ Ibid., p. 132.

448 “Os socialistas de gabinete não eram particularmente reverenciados pelos trabalhadores social-democratas e também tinham de defender-se de ataques constantes e veementes de panfletistas e porta-vozes políticos da facção empresarial. Tendiam a ver essa impopularidade com ambos os lados do conflito industrial como uma conseqüência e uma prova de sua genuína imparcialidade. Estando "acima" das brigas dos grupos de interesse concorrentes e fortificados ao mesmo tempo contra o manchesterismo e contra o marxismo por seu compromisso lógico com as técnicas históricas, não viram motivo para duvidar de que seus próprios padrões de política social estavam relativamente imunes aos erros de tendência e, portanto, seriam mais ou menos permanentes" (Ringer, 2000, p.149).
} 
os meios de produção serem convertidos em propriedade social, os membros parlamentares da social-democracia freqüentemente sustentariam que sua realização só seria possível num futuro muito remoto, praticamente imprevisível ${ }^{449}$.

O crescente apego à política de "curto alcance" e às exigências e limitações próprias da atividade parlamentar prenunciavam a ulterior reorientação teórica do partido, calcada em um viés político de cunho pragmático fundado na prevalência da prática cotidiana sobre os princípios socialistas, bem como no abandono dos postulados marxistas. Como se vê, tais idéias exerceram igualmente considerável influência sobre o pensamento de Bernstein contribuindo decisivamente em sua posterior iniciativa de trilhar o caminho do revisionismo.

Após o incidente relacionado ao "Jahrbuch für Sozialwissenschaft und Sozialpolitik", Bernstein empreendeu esforços no sentido de apaziguar as relações entre o círculo de Höchberg e os líderes da social-democracia alemã. Juntamente com Bebel, realizou uma visita a Londres em dezembro de 1980, com o objetivo de restabelecer um contato amistoso com Marx e Engels ${ }^{450}$ e ainda receber o aval destes para substituir Georg von Vollmar na editoração do "Sozialdemokrat", único órgão oficial do partido, iniciado em 28 de setembro de $1879^{451}$.

Graças ao apoio de Bebel, Bernstein conseguiu redimir-se da má impressão causada pelo artigo, sendo apontado editor do periódico produzido na Suíça. A nomeação de Bernstein como editor, em janeiro de 1881, impulsionou sua carreira no interior do partido e foi fator decisivo para a sua futura consagração como proeminente teórico da social-democracia. $\mathrm{Na}$ qualidade de editor do principal periódico da social-democracia alemã, estabeleceu uma ligação mais íntima com Engels ${ }^{452}$, criando laços de confiança e amizade ${ }^{453}$. Juntamente com

\footnotetext{
${ }^{449}$ MARX, K, ENGELS, F. “Contribuição ao problema da habitação”. In Obras escolhidas. São Paulo: AlfaOmega, v.2, 1980b, p.110.

${ }^{450}$ Bebel escreveu em suas memórias, "Aus meinem Leben" de 1910, "Eu desejava levar Bernstein comigo à toca dos leões (...) Marx e Engels eram fortemente hostis com ele, e eu queria mostrar a eles que ele não era o rapaz terrível que os dois senhores acreditavam ser" (Gay, 1970, p.46).

451 “Der Sozialdemokrat” foi proclamado o único órgão oficial do SPD no Congresso de Wyden, em 1880.

${ }^{452}$ Especialmente após a segunda visita de Bernstein a Londres, em 1884. A partir de então passam a trocar uma vasta quantidade de correspondências, posteriormente publicadas por Bernstein em 1925.

${ }^{453}$ De acordo com Peter Gay, quando Bernstein, após três meses como editor provisório da revista, pediu sua exoneração, Engels escreveu-lhe uma carta elogiosa, datada de 14/4/1881, enaltecendo suas qualidades de editor: "Nós ficamos desagradavelmente surpresos em receber seu recado de que deseja sair do jornal. Nós não podemos enxergar qualquer razão para isto, e gostaríamos muito se você reconsiderasse. Você editou o jornal habilmente desde o princípio, você lhe deu o tom certo e desenvolveu o necessário bom senso. Ao editar um jornal a erudição não é tão importante como a rápida compreensão das questões no correto espírito, e você sempre demonstrou isto (...) eu não vejo quem poderia ocupar o seu lugar, agora que Liebknecht está na prisão". (Gay, 1970, p.50). Diante dos apelos de Engels, Bebel e Liebknecht, Bernstein reconsiderou sua decisão, tornando-se editor permanente do periódico até 1890 .
} 
Kautsky - que se tornara colaborador do "Sozialdemokrat" por intermédio de Höchberg -, Bernstein passou a ser co-responsável pela tradução e organização de obras de $\mathrm{Marx}^{454}$, principalmente após a morte deste, em 1883. Sua dedicação e temperamento conferiram-lhe um bom conceito junto a Engels, como mostra a carta deste a Bebel, de 11 de fevereiro de 1881:

Eu acredito que Bernstein é mais adequado ao trabalho que Kautsky (...) Recentemente, Kautsky passou algum tempo aqui [em Londres] e tive uma séria discussão com ele. Isto me leva a acreditar que no futuro importantes diferenças de opinião entre ele e nós poderiam surgir ${ }^{455}$.

O contato com Engels propiciou a Bernstein um flerte com posições políticas mais radicais. Durante os anos em que esteve incumbido da editoração da revista, o autor procurara submeter a orientação teórica da publicação ao crivo crítico do "General" "56 . Neste sentido, entre 1882 e 1888, Bernstein assumiu posicionamentos contrários à ala moderada do partido, representada na época fundamentalmente pela fração parlamentar ${ }^{457}$.

Sob o pseudônimo de Leo ou Vitellius, o autor publicou diversos artigos em "Der Sozialdemokrat" 458 seguindo este mesmo perfil, sendo os principais referentes à oposição à lei de subsídios para a indústria naval $(1884)^{459}$, à relevância da organização sindical dos trabalhadores $(1885)^{460}$ e à diferenciação entre propriedade social e propriedade privada $(1885)^{461}$. Neste último, chegou a afirmar "nada é socialista se não subscreve completamente e sem reservas a frase clássica de "O Capital": "a concentração dos meios de produção e a socialização do trabalho chegam a um ponto em que se tornam incompatíveis com o capitalismo","462.

\footnotetext{
${ }^{454}$ Como, por exemplo, "A miséria da filosofia", originalmente escrita em francês.

${ }^{455}$ GUSTAFSSON, Bo. Marxismo y revisionismo: La critica bernsteiniana del marxismo y sus premisas histórico-ideológicas. México: Grijaldo, 1975, p.50.

${ }^{456}$ Como costumeiramente Engels era chamado.

${ }^{457}$ A fração parlamentar era composta por personalidades como Wilhelm Blos, Wilhelm Hasenclever e Ernst Brewel (Gustafsson, 1975, p.51).

${ }^{458}$ Gustafsson, 1975, p.5.

${ }^{459}$ Nesta ocasião Bernstein publicara artigos e cartas pró e contra a lei, mas foi criticado pela ala moderada que, através de uma declaração oficial, repudiou a política editorial de Bernstein e exigiu a submissão do jornal às decisões do grupo parlamentar. Bernstein recebeu esta declaração com ordens de publicá-la na íntegra, mas recusou-se por considerar um atentado à sua independência editorial, colocando seu cargo à disposição do Partido (Gustafsson, 1975, p.52).

${ }^{460}$ Artigo intitulado "Die Bedeutung der Gewerkschaftlichen Organisation der Arbeiter", no qual Bernstein destacara as limitações da luta sindical, vista como tarefa secundária do movimento operário, que necessitaria conferir um sentido político à luta: tarefa do partido político (Gustafsson, 1975, p.107).

${ }^{461}$ Artigo "Gesellschaftliches und Privateigentum", no qual ressalta que o único caminho para o socialismo passaria pela expropriação da propriedade burguesa (Gustafsson, 1975, p.107).

${ }^{462}$ Gustafsson, 1975, p.107.
} 
Como foi visto, a "fase ortodoxa" de Bernstein, caracterizada por sua aproximação com a teoria marxista, fora inequivocamente determinada pela predominante influência exercida pela figura de Engels. Em razão deste forte vínculo pessoal e intelectual, seu rompimento definitivo com o marxismo demorou a se efetivar, levando-o constantemente a reafirmar seu pertencimento à tradição marxista e a definir seu revisionismo como uma complementação - e não descarte - da teoria de Marx. Embora, conforme ulteriormente revelou $^{463}$, sentisse desde cedo a necessidade de adaptar o marxismo, Bernstein exerceu um relevante papel na sua difusão através de sua atividade jornalística. Tal fato foi reconhecido por Mehring:

Bernstein compreendeu bem como manter o jornal como um órgão de todo o partido e de proporcioná-lo, ao mesmo tempo, uma clara, certa e firme direção que se ajustava às demandas táticas sem violar princípios. Em quase nenhuma questão levantada pelas lutas políticas de uma década - certamente em nenhuma decisiva - o Sozialdemokrat manteve-se distanciado. Em virtude de suas atividades como agitador, Bernstein estava familiarizado demais com as condições da luta da classe proletária para não entender as questões em jogo. Ele trabalhava devagar e cuidadosamente; uma natureza ponderada, com um toque de ceticismo que tendia a superestimar o mérito de seus oponentes, ele gostava da briga não pela briga em si, e estava sempre pronto para uma discussão frutífera. Com Engels como seu conselheiro, Bernstein contribuiu pelo menos tanto para o esclarecimento teórico da classe trabalhadora alemã quanto para sua atividade prática. ${ }^{464}$

Contudo, sua fase mais radical logo foi interrompida quando o governo suíço, atendendo a exigências de Bismarck, passou a reprimir e perseguir os social-democratas que encontravam-se em seu território. Deste modo, Bernstein foi expulso da Suíça, refugiando-se em Londres com sua esposa, em 12 de maio de 1888. Na Inglaterra, deu continuidade a seu trabalho no "Sozialdemokrat" até o ano de 1890, quando as leis anti-socialistas foram revogadas e o órgão do partido pôde novamente ser impresso na Alemanha ${ }^{465}$.

\footnotetext{
${ }^{463}$ Cf. Carta de Bernstein a Bebel de 20 de outubro de 1898 (Gay, 1970, p.73).

${ }^{464}$ Gay, 1970, p.60-61.

${ }^{465}$ Engels, em sua carta de despedidas aos leitores, no último número do Sozialdemokrat, afirmara que esta foi "a melhor publicação que o partido já teve (...) Os princípios do Partido foram expostos e mantidos com rara claridade e certeza, e a tática da redação foi, quase sem exceção, correta” (Gustafsson, 1975, p.36).
} 
A partir de então, Bernstein passou a atuar como correspondente do jornal Vörwarts e da revista Die Neue Zeit, além de dedicar-se a estudos de caráter histórico ${ }^{466}$. Ainda impossibilitado de retornar à Alemanha, o autor aproveitou seus treze anos em Londres para estabelecer contato com uma variedade de grupos socialistas ingleses, muitos deles desprovidos de qualquer rigor conceitual e nitidez ideológica. Dentre estes, destacavam-se os "fabianos", um pequeno grupo de intelectuais que fundaram em 4 de janeiro de 1884 a "Fabian Society", organização que não possuía a pretensão de constituir um partido com vistas à tomada do poder, mas sim impregnar outros grupos políticos com suas idéias ${ }^{467}$.

Em suas memórias, Bernstein tenta frisar seu distanciamento em relação aos fabianos, ao afirmar:

Por um longo período eu tive preconceito em relação aos fabianos, esquivando-me de estabelecer relações pessoais com eles. Seu tom e método de procedimento era tão contrário ao espírito do movimento como eu o concebia que quando ouvia suas discussões eu geralmente sentia calafrios. Enquanto vivi na Inglaterra eu mantive pouco contato pessoal com Shaw e se algumas vez tivemos alguma conversa logo ficava óbvio que havia uma discordância entre nós, como se habitantes de dois mundos diferentes estivessem educadamente trocando opiniões sem o auxílio de uma terminologia comum. ${ }^{468}$

No entanto, apesar de evitar atribuir sua "guinada revisionista" à influência dos socialistas fabianos ${ }^{469}$, a poderosa impressão provocada pelo socialismo moderado e eclético por eles propugnado sobre seu pensamento foi observada por todos os seus companheiros mais próximos. Ainda em 1882, em carta a Bebel, Engels ironizava o "cômico respeito" que Bernstein dispensava aos fabianos ${ }^{470}$, em um misto de escárnio e preocupação.

Mediante a análise da teoria e da prática dos socialistas ingleses, Bernstein modificou substancialmente suas idéias sobre o marxismo e a filosofia socialista. Passou a questionar abertamente a teoria do colapso, considerando-a uma ilusão doutrinária, e a advogar pelo redirecionamento da tática empregada pelo partido, de modo que passasse a atender às

\footnotetext{
466 Dentre estes escritos cabe destacar sua obra sobre o movimento cartista "Die Chartisten-Bewegung in England", publicada em Zurique em 1887, seu livro "Ferdinand Lassalle como reformador social", de 1893, e "Cromwell e Comunismo: socialismo e democracia na grande revolução inglesa", de 1895.

${ }^{467}$ Em 1889 publicaram os "Ensaios Fabianos", composto por três artigos de autoria de Georg Bernard Shaw e Sidney Webb ("As bases do socialismo", "A organização da sociedade", "A transição para a socialdemocracia").

${ }^{468}$ BERNSTEIN, E. My years of exile: reminiscences of a socialist, 1915-1921. In: www.marxists.org.

${ }^{469}$ Entre os membros mais destacados dos fabianos estavam Gaham Wallas, Bernard Shaw, Sidney e Beatrice Webb, Stewart Headlam, Keir Hardie, John Burns e Ramsay MacDonald (Gay, 1970, p.68).

${ }^{470}$ Gustafsson, 1975, p.177.
} 
demandas imediatas, consubstanciadas nas reformas sociais graduais e na socialização resultante da pressão democrática.

Em dois artigos de 1895, o primeiro escrito em agosto, intitulado "A evolução dos partidos ingleses", e o segundo em outubro, sendo o posfácio ao trabalho de Sidney e Beatrice Webb sobre "História do trade-unionismo britânico", Bernstein demonstrara grande apreço pelos objetivos e métodos de trabalho do movimento sindical inglês. Nesta última obra realizou uma crítica à teoria da luta de classes, que retomaria alguns anos depois, em meio à querela revisionista:

Em particular na sociedade burguesa moderna com sua extraordinária multiplicidade de grupos de interesses e suas relações recíprocas é quase inevitável que os problemas do movimento substituam temporalmente do horizonte aos antagonismos profundos (...) A teoria da luta de classes de nossos dias, tal como é erroneamente entendida com demasiada freqüência, experimenta assim uma retificação essencial. Não só os inimigos mal intencionados mas também seus fiéis adeptos associam a ela a idéia de uma transformação contínua, homogênea e simultânea das relações industriais. Assim, uma lei de tendência é entendida como se estivesse afirmando um fato acabado, fato que só assinala a direção em que se orienta uma linha de movimento reconhecida. De fato, todavia, estamos muito longe daquela homogeneidade do curso evolutivo e inclusive se fosse alcançada permaneceriam todavia atuantes grandes desigualdades na natureza dos ramos industriais singulares que seria fatal ignorar. ${ }^{471}$

Se o contato com os fabianos despertou-lhe a atenção para a possibilidade de revisão de muitas premissas filosóficas e políticas do marxismo, convém ressaltar que a preocupação de Bernstein com a fundamentação teórica de seu reformismo é o ponto que ele próprio considerava crucial em sua distinção em relação aos fabianos, vistos por ele como pragmáticos e avessos a teorias e princípios $^{472}$. Se, por um lado, a liberdade em relação a dogmas e doutrinas lhes permitiria uma flexibilidade na ação, determinada por critérios pragmáticos e utilitários, o desapego à teoria poderia conduzi-los a posturas aparentemente incoerentes e contraditórias:

Em grande parte Shaw praticava o que nós alemães entendemos como "conflito de classe", mas não aceitava este nome pois, para ele, este teria uma outra conotação. Em sua mente, o movimento socialista estende-se para além da classe que nós vemos como sua real defensora, e sua fé na energia auto-

\footnotetext{
${ }^{471}$ Gustafsson, 1975, p.187.

472 Cf. BERNSTEIN. "Observaciones generales sobre el utopismo y el ecletismo". In: Las premisas del socialismo y las tareas de la socialdemocracia. México: Siglo XXI, 1982.
} 
sacrificadora desta classe era pequena. Ele tem consciência de ser ele mesmo um ideólogo socialista, mas seu pensamento é demasiadamente crítico para jurar fidelidade a idéias abstratas. Em sua ideologia ele é um realista; pode-se dizer, por paradoxal que isto possa soar, um ideólogo crítico, e talvez este paradoxo possa servir como uma chave para muitas aparentes contradições em seu comportamento ${ }^{473}$.

Não obstante as diversas críticas de Bernstein aos fabianos, sua formulação teórica, que começara a tomar forma no início da década de 1890, apresentava uma grande afinidade com o fabianismo, o que levou muitos estudiosos, como Peter Gay, a considerarem-nas concepções políticas indistintas ${ }^{474}$. A crítica à teoria do valor de Marx, a ênfase nas reformas e na gradual implantação de um socialismo municipal, a tática moderada de alianças e compromissos com as classes burguesas e o repúdio à via revolucionária, seriam traços fundamentais da política fabiana igualmente manifestados em Bernstein. Podemos reconhecer tal semelhança ao analisarmos a seguinte passagem de Sidney Webb, extraída dos "Ensaios Fabianos":

Os defensores da reconstrução social aprenderam a lição da democracia e sabem que é através do lento e gradual avanço da consciência popular em direção aos novos princípios que a reorganização da sociedade virá, passo a passo. Qualquer estudioso da sociedade, atualizado com seu tempo, seja ele socialista ou individualista, percebe que mudanças importantes só podem ser (i) democráticas, e portanto aceitáveis pela maioria do povo e assimiláveis por todos; (ii) graduais, não causando portanto deslocamentos, por mais rápido que seja o progresso; (iii) não vistas como imorais pela massa do povo, e portanto não a desmoralizando subjetivamente; (iv) nesse país, em qualquer caso, constitucional e pacífica. ${ }^{475}$

Ademais, podemos notar que o rol de reformas sociais propostas por Bernstein aproxima-se consideravelmente do elenco de reformas apontado pelos socialistas ingleses da Fabian Society. O programa fabiano previa essencialmente seis reformas principais: a reforma fiscal, a ampliação das leis fabris, a reforma do ensino, a reorganização administrativa da lei

473 BERNSTEIN, E. Meus anos de exílio: reminiscências de um social-democrata, 1915-1921. In: Www.marxists.org.

474 Sergundo Peter Gay, "mesmo um observador superficial pode reconhecer o fato de que o fabianismo e o revisionismo alemão são irmãos, senão gêmeos. Ambas as doutrinas originaram-se no mesmo país, com apenas alguns anos de distancia uma da outra, é considerado axiomático que Eduard Bernstein tenha obtido suas idéias fundamentais dos fabianos". Bo Gustaffson, aponta no mesmo sentido ao afirmar que "o revisionismo de Bernstein era uma forma de fabianismo inglês" (Gustafsson, 1975, p.437).

${ }^{475}$ WEBB, Sidney. "As bases históricas do socialismo". In: Utópicos, heréticos e malditos / [org.] Aloísio Teixeira. Rio de Janeiro: Record, 2002, p.348. 
dos pobres, a ampliação das atribuições dos municípios e a reforma do sistema político ${ }^{476}$. Tais reformas decorreriam de um lento e gradual avanço da consciência popular em direção aos novos princípios; ou seja, o "inconsciente abandono do individualismo" levaria a população a aderir a projetos de reforma social de amplo alcance, a serem realizados pelo Estado e pelos Municípios.

Para os fabianos o socialismo seria fruto da própria extensão e consolidação da democracia, isto é, seria o lado econômico do próprio ideal democrático. O aumento constante da regulação governamental sobre a empresa privada, o crescimento da administração municipal e o rápido deslocamento da incidência de impostos diretamente para a renda e os juros delineariam "o irresistível deslizamento em direção ao socialismo coletivista"477.

De acordo com a perspectiva fabiana, portanto, "o irresistível progresso da democracia" estaria levando a sociedade capitalista em direção ao socialismo ${ }^{478}$, uma vez que a cada dia ampliar-se-ia o consenso de que o resultado inevitável da democracia é o controle pelo próprio povo não só de sua organização política mas também dos principais instrumentos de produção de riqueza. Por conseguinte, a substituição gradual da anarquia da concorrência pela cooperação organizada e "a conseqüente recuperação, da única maneira possível, do que Stuart Mill denominou 'a enorme parcela que os proprietários dos instrumentos de produção apropriam do produto", ${ }^{479}$, seriam realizadas de forma consensual, pacífica e legal:

A necessidade de cautela e mudança gradual deve ser óbvia para todos aqui, e poderia ser óbvia para todos, em qualquer lugar, desde que se discutisse com os catastrofistas de forma corajosa e sensata. O que significa, especificamente, então, uma transição gradual para a social-democracia? Significa a extensão gradual do direito de voto; e a transferência da renda e dos juros para o Estado, não de um só golpe, mas aos poucos. Encarada deste ângulo, pode-se ver que já fomos bem longe na caminhada, empurrados por muitos políticos que nem sequer

\footnotetext{
${ }^{476}$ Cf. WEBB, Sidney. “As bases históricas do socialismo”. In: Utópicos, heréticos e malditos / [org.] Aloísio Teixeira. Rio de Janeiro: Record, 2002, p.369. - A reforma fiscal consistiria na completa transferência da carga que incide sobre os trabalhadores para os que recebem rendas e juros, com vistas à extinção gradual e final dessa última classe; a ampliação das leis fabris teria o intuito de elevar universalmente o padrão de conforto pela aprovação geral do salário mínimo e da jornada diária de trabalho máxima ; a reforma do ensino permitiria que todas as crianças obtenham a "melhor educação de que sejam capazes" ; a reorganização administrativa da "lei dos pobres" possibilitaria assistir generosamente, e sem estigma, aos idosos, doentes e desamparados por falta temporária de emprego, "sem relaxar os testes contra os capacitados para o trabalho que permanecem ociosos"; a ampliação das atribuições dos municípios dar-se-ia através da organização gradual do trabalho com objetivos públicos e a supressão dos capitalistas e intermediários privados; e a reforma do sistema político teria como objetivo alcançar a mais rigorosa representação e expressão da vontade da maioria do povo.

${ }^{477}$ Webb, 2002, p. 375.

${ }^{478}$ Webb, 2002, p. 346.

${ }^{479}$ Webb, 2002, p. 348.
} 
imaginam que estão tocando o socialismo - e que repudiariam energicamente esse toque como se fosse contaminá-los. ${ }^{480}$

Logo, Bernstein encontrara nos fabianos a tentativa de sustentação de um "socialismo evolucionário" realizado por meio de reformas graduais cumulativas, algo que já havia buscado entre os socialistas de cátedra alemães. Embora Bernstein atribua sua visão da evolução social à teoria social de Marx, citando, para tanto, a passagem do prefácio de "O Capital" em que este afirma que a "atual sociedade não é um cristal sólido, mas um organismo capaz de mudar e que está em constante processo de mudança"481, sua concepção linear e orgânica da evolução social e seu elevado otimismo assemelham-se ao spencerianismo encontrado entre fabianos como Sidney Webb:

Devido principalmente aos esforços de Comte, Darwin e Herbert Spencer, não podemos mais imaginar a sociedade ideal como um Estado imutável. O ideal social deixou de ser estático para tornar-se dinâmico. A necessidade de crescimento e desenvolvimento constantes do organismo social tornou-se axiomática. Nenhum filósofo hoje em dia procura outra coisa que não a evolução gradual da nova ordem a partir da antiga, sem solução de continuidade nem ruptura abrupta de todo o tecido social em algum momento do processo. O novo torna-se, ele mesmo, velho, muitas vezes antes de ser conscientemente reconhecido como novo; e a história não mostra nenhum exemplo de súbita realização de utopias nem de revoluções romanceadas. ${ }^{482}$

Convém ressaltar, todavia, que tanto Marx como Engels opunham-se ferozmente a tal concepção evolucionista e idealista da história humana. Longe de conceber um desenvolvimento linear, sua postulação teórica baseada na lógica dialética marcava as contradições e descontinuidades do processo histórico. Em resumo, como nos elucida Leandro Konder, para Marx "o presente não engendra automaticamente o futuro através de uma dinâmica fatal ou espontânea: o futuro precisa lutar para nascer, para assumir uma feição determinada; precisa enfrentar criticamente o presente" ${ }^{\text {"483. }}$.

As diferenças entre o marxismo e o fabianismo não se limitavam a discordâncias em termos teóricos. Em entrevista realizada ao Daily Chronicle, em junho de 1893, Engels, ao ser

\footnotetext{
${ }^{480}$ SHAW, Georg Bernard. "A transição para a social-democracia”. In: Utópicos, heréticos e malditos / [org.] Aloísio Teixeira. Rio de Janeiro: Record, 2002, p.392. Escrito em 1888.

${ }^{481}$ MARX, Karl. O Capital: Crítica da Economia Política. vol.1, livro I. São Paulo: Nova Cultural, 1985, p.14.

${ }^{482}$ Webb, 2002, p. 344-345.

${ }^{483}$ KONDER, Leandro. A derrota da dialética. Rio de Janeiro: Campus, 1988, p.20.
} 
indagado a respeito da eventual similitude entre os programas políticos da social-democracia e da Sociedade Fabiana, ressaltou as divergências existentes na prática das duas organizações:

Considero a Sociedade Fabiana nada mais do que um braço do Partido Liberal. Ela não procura por outra salvação social que não aquela fornecida pelo partido. Nós nos opomos a todos os partidos políticos existentes e nós iremos combater a todos eles (...) Nós não acreditamos em permear partidos de classe média. Nós estamos permeando o povo. ${ }^{484}$

A ambigüidade presente no pensamento de Eduard Bernstein e sua afinidade com os fabianos demonstram como o contexto histórico-social vivenciado nos fins do século XIX deu margem às mais diversas interpretações acerca do curso da sociedade capitalista. Seu desvio teórico em direção ao revisionismo, portanto, pode ser melhor compreendido à luz do confronto ideológico existente no seio do próprio movimento socialista - motivado pelas mudanças na conjuntura política e econômica européia do período -, não sendo um simples reflexo de uma postura oportunista ou de uma inclinação particular à defesa dos interesses burgueses.

Por conseguinte, se após 1895 o discurso de Bernstein parece sofrer uma drástica mudança, tal fato não deve ser entendido de forma isolada e descontextualizada. A ascensão eleitoral da social-democracia, a expansão numérica e estrutural do partido e dos sindicatos, a atenuação da repressão política, a promulgação de leis sociais de proteção ao trabalho, o surto industrial e a superação da crise de recessão econômica em voga durante toda a década de 80 foram vistos por Bernstein como sinais de que o capitalismo estaria em vias de transformação, dando origem a uma nova forma social mais aberta e democrática.

Os anos de 1888 a 1895 testemunharam, então, a sua lenta, gradual e hesitante adesão ao revisionismo. No ano de 1889, Bernstein concedeu uma entrevista à revista Justice a respeito do congresso inaugural da Segunda Internacional, em Paris, na qual contestou ardorosamente o Partido Possibilista francês. Nesta ocasião, condenava o fato de que estes "socialistas ministerialistas" estariam no momento "com todas as intenções e propósitos de um partido do governo" 485 , ao aliarem-se à burguesia republicana.

No ano seguinte publicou uma série de artigos no Sozialdemokrat, sob o pseudônimo de Leo, nos quais enfatizava a responsabilidade parlamentar do SPD, mas simultaneamente reafirmava o compromisso com a revolução, advertindo para a possibilidade de degeneração

\footnotetext{
${ }^{484}$ Cf. www.marxist.org.

${ }^{485}$ BERNSTEIN, E. "O Congresso Internacional dos Trabalhadores de 1889". In: www.marxist.org. Publicado na revista Justice, em 1889.
} 
do reformismo em um "cretinismo parlamentar" ${ }^{486}$. Ainda em 1890 a social-democracia começara a colocar em pauta a discussão acerca da questão agrária, na qual Georg von Vollmar aparecera como o epítome do reformismo e da política de alianças. Bernstein, então, exprimiu apoio à formulação de uma política agrária que buscasse a um só tempo atrair a pequena-burguesia para o partido e unir forças com outros partidos políticos comprometidos com as mudanças sociais.

O percalço do pensamento bernsteiniano nestes dois anos demonstra como sua teoria buscava incessantemente acompanhar a prática do movimento social-democrata, adaptando-se às suas necessidades mais imediatas. A sua ênfase na prática em detrimento da teoria é evidenciada mais uma vez quando Bernstein é chamado a colaborar na elaboração da parte prática do novo programa do partido, submetido à aprovação no Congresso de Erfurt, em 1891. Neste documento o autor elencara as reformas a curto prazo que a social-democracia deveria almejar, tais como o sufrágio universal, a supressão de todas as limitações aos direitos políticos, a gratuidade da Justiça e da assistência médica, impostos progressivos sobre os rendimentos e a fortuna e uma eficaz legislação nacional e internacional protetora do trabalho.

Embora dedicado às tarefas práticas do partido, Bernstein ainda debruçava-se sobre questões de cunho teórico. Deste modo, em 1891 direcionou críticas a Lassalle (no prefácio que escrevera à coletânia de trabalhos deste) e a autores liberais reformistas como Gerhart von Schulze-Gaevernitz ${ }^{487}$ - particularmente seus escritos "Zum sozialen Frieden" e "Der Grossbetrieb", que defendiam a tese de que a luta de classes tenderia a diminuir em violência, a miséria do proletariado estaria desaparecendo e a paz social sobreviria ao crescimento industrial, responsável por melhorar a qualidade de vida das classes trabalhadoras.

Em 1893 o autor refutou, ainda com base em argumentos marxistas, Julius Wolf (“Sozialismus und Kapitalistische Gesellschaft”), através do artigo "Der neueste Vernichter des Sozialismus", na Neue Zeit. Embora engajado na tarefa de criticar tais autores, Bernstein reconheceu, posteriormente, as dúvidas teóricas remanescentes de tal debate ${ }^{488}$. A este respeito, Bernstein revelou em sua autobiografia:

\footnotetext{
${ }^{486}$ Estes artigos foram publicados em 2/4/1890, 3/5/1890 e 4/5/1890, sob o título de “Klippen” (Gustafsson, 1975, p.66).

487 Bernstein respondera na Neue Zeit, através do artigo "Carlyle und die Sozialpolitische Entwicklung Englands", em 1891, e "Technisch-ökonomischer und sozial-ökonomischer Fortschritt", em 1893 (Gay, 1970, p.71).

${ }^{488}$ Entre 1891 e 1893 Bernstein escreveu uma série de artigos na Neue Zeit nos quais defendia Marx da crítica acadêmica de autores como Georg Adler (que em 1878 publicou tese de livre-docência intitulada "Pressupostos
} 
Eu não escondi de mim mesmo o fato de que as objeções que eles levantaram não foram totalmente respondidas (...). Por mais que eu lutasse contra isto, comecei a duvidar das doutrinas que eu tinha considerado até então incontroversas. Os anos seguintes trouxeram acontecimentos que aumentaram ainda mais minha incerteza. ${ }^{489}$

A incerteza de Bernstein cresceu à medida que as condições econômicas da Alemanha avançavam e prosperavam. Em sua opinião, persistir na defesa da teoria marxista, com sua descrição da tendência decrescente da taxa de lucro (exposta no terceiro volume do Capital, publicado em 1894), diante de uma realidade substancialmente diferente significaria tentar conciliar o inconciliável.

Em meados dos anos 90 do século XIX, aconteceu na Europa e na Alemanha, não em último lugar, um auge dos negócios de uma potência e duração como não se conhecia há muito tempo. Este auge produziu sobre mim uma forte impressão. Estava em crassa contradição com a teoria do aumento inevitável e da crescente gravidade da crise econômica que havia de culminar finalmente na derrubada total da economia tal como resulta da lógica aparentemente (...) das exposições de Karl Marx no Capital e como havia sido propagado, sobretudo, por August Bebel com grande êxito no Partido Social-Democrata ${ }^{490}$.

Da mesma forma, Bernstein escreveu um artigo na Neue Zeit atacando a política abstencionista praticada na Prússia, no qual recomendava que o partido se aliasse aos burgueses progressistas nas eleições. Essa proposta foi discutida em 1893 pela Assembléia do partido em Colônia, tendo sido rechaçada por unanimidade pelo $\mathrm{SPD}^{491}$.

Este posicionamento ambíguo e titubeante de Bernstein levou Bebel a ironizá-lo em carta a Engels, de 14 de setembro de 1892, ao declarar: "Ede volta a escrever hoje no Vorwärts de seu modo frouxo, de que não se sabe bem se é carne ou pescado" 492 . Engels igualmente demonstrara ter ciência da frágil convicção nos princípios teóricos e na prática revolucionária que Bernstein manifestava ${ }^{493}$. Já em 3 de novembro de 1893, Engels escreve a Kautsky:

da crítica de Marx à atual economia política"); Julius Wolf, professor em Zurique, Lujo Brentano, representante da escola histórica alemã e Schulze-Gavernitz, discípulo de Brentano.

${ }^{489}$ Gay, 1970, p.72.

${ }^{490}$ Bernstein. "Zur Geschichte des Revisionismus", apud, Gustaffson, 1975, p.24.

${ }^{491}$ COLE, George Douglas Howard. Historia del pensamiento socialista: la segunda internacional: 1889- 1914. México: Fondo de Cultura Economica, v.1, 1959, p.247.

${ }^{492}$ Gustaffson, 1975, p.111.

${ }^{493}$ No prefácio à primeira edição de "Os pressupostos do socialismo e as tarefas da social-democracia", escrito em janeiro de 1899, Bernstein deixa clara a anterioridade de suas divergências: "Estou plenamente consciente de que em alguns pontos importantes discrepo das concepções teóricas de Karl Marx e Friedrich Engels, ainda que seus escritos tenham exercido a máxima influência sobre minhas idéias socialistas e, sobretudo Friedrich Engels 
Ede me deixou ontem à tarde o que você escreveu acerca de um artigo sobre a greve como meio de luta política. Eu o desaconselhei decididamente a escrever o artigo. Em minha opinião já deixou suficientemente claro na história da eletividade das três classes [artigo de 1893 que defendia a participação do SPD nas eleições para a Assembléia Legislativa regional prussiana] que se converteu em um homem que perdeu o contato com as massas e que argumenta de fora, do gabinete de estudos, doutrinariamente, sobre questões da práxis imediata $(\ldots) .^{494}$

Engels, com sua aguçada percepção, foi capaz de prever os rumos que iria tomar o pensamento bernsteiniano, embora a lealdade de Bernstein para com seu mestre e amigo tenha procrastinado a sua divergência pública com o marxismo até a morte do General, em 1895. Cabe ressaltar que apesar de sua vacilante orientação teórica, Bernstein inspirara a confiança de Engels que o nomeou seu executor testamentário. ${ }^{495}$

Entre seus primeiros textos assumidamente revisionistas encontram-se a "Introdução para a edição alemã de "History of Trade Unions" de Beatrice e Sidney Webb", escrito em 1895, e o comentário e epílogo elaborados por Bernstein entre 1895 e 1896 para a edição alemã do livro "História da Revolução Francesa de 1848", de Louis Héritier. Nestes escritos Bernstein realiza uma dura crítica aos revolucionários, opondo-se radicalmente à interpretação exposta por Marx em “A Luta de Classes na França - de 1848 a 1850”.

Assim Bernstein descreveu este processo de transição intelectual, no qual desvencilhase dos princípios marxistas:

Esta minha mudança resulta de um longo desenvolvimento, ou melhor, demorou muito tempo até que eu estivesse completamente certo de que esta transformação não estava restrita a questões específicas, mas tangeria os fundamentos do marxismo. Até dois anos atrás eu tentei, através da adaptação

tenha me honrado com sua amizade pessoal até a sua morte, chegando ao grau de deixar-me em seu testamento uma lembrança póstuma de sua grande confiança. Estas discrepâncias não surgiram, obviamente, nos últimos anos, sendo fruto de um conflito interno que data de muitos anos [grifo nosso]; e tenho provas de que não era segredo para Friedrich Engels..." (Bernstein, 1982, p. 99).

${ }^{494}$ Ibid, p. 113.

495 Eleonor Marx, em uma de suas últimas cartas, manifestara preocupação com “o amigo fiel” que após a morte de Engels adotara uma atitude crítica e pessimista, tornando-se prejudicial ao movimento: "No fim de sua vida, foi Bernstein quem inquietou Eleonor que via, com melancolia, a subida das águas do "revisionismo". Apesar de manter a confiança total no homem e na sua lealdade - Ede é um amigo fiel, nem um pouco dado a intrigas Tussy deplora o pessimismo crítico ao qual ele se abandona, após a morte do General. "O Vorwärts cai cada vez mais sob a influência de Bernstein, e seus artigos desanimadores não são nem um pouco oportunos. Evidentemente, uma atitude crítica é necessária e útil. Mas, há momentos em que um entusiasmo, ainda que sem muito espírito crítico, tem mais valor. A posição de Bernstein é nefasta para o movimento (...) Sua atitude é indefensável (...). infelizmente, agora que não temos mais o General (Engels), não há mais ninguém que possa Ter influência sobre Bernstein e fazê-lo cair em si" (Carta de Eleonor Marx a Laura Lafargue de 8/1/1898 apud PERROT, 2005, p. 75) 
dos ensinamentos de Marx torná-los compatíveis com as realidades práticas. Finalmente, eu compreendi completamente a impossibilidade de tal tática quando eu dei uma palestra na Sociedade Fabiana sobre o assunto, "O que Marx realmente ensinou", há cerca de um ano e meio atrás. Eu ainda tenho o manuscrito daquela explanação; é um assustador exemplo de uma tentativa bem-intencionada de resgate. Eu queria salvar Marx; queria mostrar que ele havia previsto tudo que havia acontecido. Quando eu terminei minha "performance artística" e li novamente meu discurso, passou pela minha cabeça o seguinte pensamento: você está fazendo injustiça à Marx, aquilo que você está dizendo não é Marx. E algumas poucas perguntas inofensivas do arguto fabiano Hubert Bland após a palestra, que eu respondi da maneira antiga, realmente me atingiram. Eu disse a mim mesmo - isto não pode continuar. É impossível conciliar o inconciliável. O que se deve fazer é deixar claro aonde Marx acertou e onde ele errou ${ }^{496}$.

Este processo culminou em uma série de artigos publicados pela Neue Zeit, reunidos sob o nome "Problemas do Socialismo" "497, nos quais Bernstein expõe abertamente sua intenção de contrapor-se à teoria de Marx com base em dados empíricos da Alemanha de sua época. Desta forma, Bernstein pretende colocar em xeque a teoria e a prática apregoadas pelo partido, repreendendo a social-democracia por adotar uma posição política calcada em uma fraseologia radical, inteiramente incompatível com a tática adotada.

Assim, tivera início o debate revisionista no seio da social-democracia alemã, que ganhou contornos mais precisos durante o Congresso de Stuttgart, de 1898, ao qual Bernstein enviou uma mensagem apresentando suas teses principais. Em resposta à mensagem de Bernstein Bebel escreveu-lhe a seguinte carta, de 16/10/1898, que na realidade sintetiza a trajetória intelectual de Bernstein até seu revisionismo:

Novamente estás atravessando uma mutação (...), a mutação que considero mais perigosa de todas as que tens sofrido até agora. E isto porque o único remédio que poderia servir de ajuda não se pode utilizar por razões conhecidas; refiro-me a que mudasses para um meio diferente. Como velho amigo e como teu companheiro de luta que sou, quero ser sincero.

\footnotetext{
${ }^{496}$ Carta de Bernstein a Bebel, de outubro de 1898 (Gay, 1970, p.73).

${ }^{497}$ Encontramos nos "Probleme des Sozialismus" os seguintes artigos: "Observações gerais sobre o utopismo e o ecletismo" ("Allgemeines über Utopismus und Eklektizismus", de outubro de 1896); "Uma teoria sobre os domínios e limites do coletivismo" ("Eine Theorie der Gebiete und Grenzen des Kollektivismus", de 1896/1897); "A situação atual do desenvolvimento industrial na Alemanha" ("Der gegenwärtige Stand der industriellen Entwicklung in Deutschland", de 1896/1897); "O novo desenvolvimento das relações agrárias na Inglaterra" ("Die neue Entwicklung der Agrarverhältnisse in England", de 1896/1897); "A significação política e social do espaço e do número" ("Die sozialpolitische Bedeutung von Raum un Zahl”, de 1896/1897); "A luta da socialdemocracia e a revolução da sociedade" ("Der Kampf der Sozialdemokratie und die Revolution der Gesellschaft", de 1897/1898) e "O fator realista e o fator ideológico no socialismo" ("Das realistische und das ideologische Moment im Sozialismus”, de 1897/1898).
} 
Indaguei os motivos que te levaram às posições que manténs atualmente e me dei conta, em primeiro lugar, de que, nos quase trinta anos que nos conhecemos, teus pontos de vista experimentaram uma mudança fundamental sempre que sobre ti atuam durante largo tempo outras influências e impressões. Em estas mudanças não tem sido obstáculo tua tendência a buscar a verdade, nem tua grande agudeza; as mudanças foram impulsionadas muito mais pelo fato de que consideras o meio em que vives em um momento determinado como dotado de uma validade geral que tentas provar, com toda tua agudeza, de um modo diferente. Lembre-se por um momento de todas as mudanças que experimentou ao longo do tempo que nos conhecemos. Entrastes no partido como partidário de Eisenach. Alguns anos depois, sob a influência das conferências e da literatura dühringiana te fizestes dühringiano entusiasta. Depois conheceste Höchberg. Os dois retiraram-se para os idílicos lagos da alta Itália e em contato com ele te convertestes em höchbergiano e, como tal, escrevestes junto com Höchberg e Schramm aquele artigo (1879) que nos encolerizou tanto a todos e que recorda muito a tuas atuais opiniões, só que hoje vais todavia mais longe. Este artigo e o que ocorreu com Höchberg e por sua culpa constituíram a causa, como sabes, de nossa "viagem de penitência" a "Engelsburg" de Londres, em que realmente o único penitente eras tu e eu era o "chefe e patrão protetor" ante a cólera dos dois senhores. Bem, nós voltamos para casa com a necessária "absolvição" e te converteste em redator do Sozialdemokrat e no ambiente de Zurique, entre nossos camaradas, que naquele momento compartilhavam um espírito altamente revolucionário por causa da vergonhosa situação que provocava a lei anti-socialistas, te fizestes o mais perfeito representante de suas posições e aspirações; aquela época foi o momento brilhante de tua vida e nada estava melhor disposto em ti que Marx e Engels. Tua mudança para a Inglaterra e teu constante contato íntimo com Engels, etc., não modificaram, em princípio, nada tuas posições. Mas após sua morte, novamente mudaram teus pontos de vista na atmosfera inglesa, nas condições inglesas e entre os contatos que mantinhas ali, uma mudança que a maioria de nós vê com pesar e preocupação. ${ }^{498}$

A carta apresentada possui extrema relevância para a compreensão das origens do revisionismo de Bernstein e das razões pelas quais uma figura de tamanha importância no movimento social-democrata assumiu uma posição de crítica e contestação à práxis partidária, passando a ser concebido como um "herege" nos círculos marxistas. Ao mesmo tempo em que aponta traços da personalidade de Bernstein como inconstância e sugestionabilidade, revela igualmente a sua honestidade intelectual e preocupação crítica.

\footnotetext{
${ }^{498}$ Gustafsson, 1975, p.177- 178.
} 
Sua sincera modéstia combinada com a necessidade de sua constante legitimação e aceitação nos círculos social-democratas levaram-no a reiterar sua despretensão em formar uma doutrina própria, defendendo antes a revisão e clarificação do socialismo marxista. Em sua opinião, tal esforço não exigiria a completa substituição do marxismo por uma nova teoria ou uma construção sociológica completamente diferente ${ }^{499}$, mas apenas o desenvolvimento ou complementação das idéias políticas marxianas, de forma a considerar a mudança das condições econômicas e políticas.

Com efeito, Bernstein declarara que as únicas correções ao método de Marx que poderiam ser descobertas em seus trabalhos seriam aquelas feitas por ninguém menos do que o próprio Engels ${ }^{500}$. Aludindo à última obra de Engels, a introdução elaborada em 1895 à obra de Marx "As Lutas de Classes na França, de 1848 a 1850",501, Bernstein afirmara que Engels teria aderido ao reformismo, ao condenar abertamente a revolução de minorias e o método de barricadas $^{502}$. Deste modo, a seu ver, o epíteto de "revisionista" - que lhe fora atribuído por correntes rivais - conduziria a erros, na medida em o afastaria definitivamente da tradição marxista, além de aglutinar diferentes matizes teóricos sob uma mesma e única definição ${ }^{503}$.

$\mathrm{Na}$ tentativa de depurar o termo e sistematizar suas idéias, Bernstein publica em 14 de março de 1899 o livro "Os pressupostos do socialismo e as tarefas da social-democracia" (Die Voraussetzungen des Sozialismus und die Aufgaben der Sozialdemokratie), considerado a obra basilar do revisionismo. Tal livro foi objeto de inúmeras polêmicas, sendo debatido em diversos congressos e periódicos do partido.

Alguns meses após a publicação do livro, o Congresso de Hannover coordenou discussões acerca do tema nas quais foram questionadas a pertinência das críticas à teoria marxista e suas implicações práticas. A despeito das inúmeras críticas advindas dos setores à esquerda do partido ${ }^{504}$ e da categórica rejeição de suas idéias, Bernstein não chegou a ser

\footnotetext{
${ }^{499}$ BERNSTEIN. "To my socialist critics". In: Selected writings of Eduard Bernstein: 1900 - 1921. New Jersey: Humanities Press, 1996, p33-34. Prefácio à edição francesa de "Os Pressupostos do socialismo e as tarefas da social-democracia", escrito em 1900 e republicado na Sozialistische Monatshefte no mesmo ano.

${ }^{500}$ Ibid, p. 37.

501 "Só em 1926, após Riazanov haver publicado as passagens retiradas da "Introdução" de Engels, Bernstein cedeu o artigo original ao SPD”, sem os cortes realizados pelos líderes do Partido(Gustafsson, 1975, p.153).

${ }^{502}$ Bernstein, 1982, p.132.

503 BERNSTEIN. "The Marx cult and the right to revise". In: Selected writings of Eduard Bernstein: $1900-$ 1921. New Jersey: Humanities Press, 1996, p. 46. Artigo comemorativo dos vinte anos da morte de Karl Marx, publicado em 1903 pela Sozialistische Monatshefte.

${ }_{504}$ Bernstein recebeu inúmeras críticas sob a forma em artigos de personalidades como Kautsky, na Vorwärts e Neue Zeit, compilados no livro "Bernstein e o Programa Social-Democrata" (Bernstein und das sozialdemokratische Programm) de 1899, Rosa Luxemburg ("Reforma ou revolução?", de 1898) e Mehring, em
} 
expulso do $\mathrm{SPD}^{505}$. O autor, no entanto, não interpretara tal resultado como um sinal de derrota do grupo revisionista:

No ano passado o congresso do Partido Social-Democrata tomou lugar em Hannover. Delegados gastaram uma considerável quantidade de tempo na discussão do meu livro; almas passionais previram um veredicto aniquilador, e não faltaram discursos almejando tal resultado. Contudo, o bom senso e a experiência prática venceram o "espírito de igreja", dando origem a uma resolução que meramente critica a forma de minhas idéias, enquanto faz importantes concessões ao conteúdo delas. Ela proclama a permissividade de coalizões eleitorais, reconhece a utilidade de cooperativas econômicas para o projeto emancipatório do proletariado, e abandona a idéia de que o corrente programa do partido pode vincular mais do que a declaração de princípios e as demandas fundamentais. ${ }^{506}$

Bernstein, portanto, entrevia na postura do partido a vitória e realização concreta de suas idéias. Embora o SPD permanecesse atrelado a uma terminologia revolucionária, na prática estaria corroborando e fortalecendo a tática revisionista, voltada para a obtenção de resultados imediatos. Na realidade, Bernstein percebia o fato de que cada vez mais suas idéias tornavam-se a perspectiva comum dentro do partido ${ }^{507}$, ainda que fossem oficialmente repudiadas. Ignaz Auer, socialista da Baviera, em carta a Bernstein de 8/9/1899, identificou igualmente tal tendência em curso no SPD, que enveredaria inelutavelmente em direção ao reformismo e à desvinculação entre sua teoria e prática:

Crês que é possível que um partido que conta com suas publicações há anos e com uma organização que data de quarenta anos atrás e uma tradição ainda mais antiga mude sua orientação de uma forma tão simples? Para os membros mais influentes do partido seguir a atuação que você propõe significaria deslocar o partido e lançar por terra o trabalho de várias décadas. Querido Ede, não se decide formalmente fazer o que você propõe, não se diz, mas se faz. Toda nossa atuação inclusive em tempos da vergonhosa legislação anti-socialista -

sua revista "Leipziger Volkzeitung”. Além disto Bebel realizou um discurso de 6 horas contra o livro de Bernstein no Congresso de Hannover, 1899.

${ }^{505}$ Sua expulsão do partido chega a ser cogitada por Bebel (Carta de Bebel a Viktor Adler de 8/4/1899). Já Kautsky tentou convencê-lo a deixar o partido voluntariamente e aderir ao socialismo inglês (Carta de Kautsky a Bernstein de outubro de 1898) (Gay, 1970, p.79-80).

${ }^{506}$ BERNSTEIN. "To my socialist critics". In: Selected writings of Eduard Bernstein: 1900 - 1921. New Jersey: Humanities Press, 1996, p.42. Prefácio à edição francesa de "Os Pressupostos do socialismo e as tarefas da social-democracia", escrito em 1900 e republicado na Sozialistische Monatshefte no mesmo ano.

${ }^{507}$ BERNSTEIN. "From someone pronounced dead". In: Selected writings of Eduard Bernstein: $1900-1921$. New Jersey: Humanities Press, 1996, p. 46. Artigo publicado em 1905 pela Sozialistische Monatshefte, p. 64. 
foi a atuação de um partido social-democrata reformista. Um partido que tem em conta as massas não pode ser outra coisa. ${ }^{508}$

Em carta a Bernstein, Georg von Vollmar solidarizara-se com ele e atentara para o paradoxo existente entre a teoria e a prática do SPD, ao declarar que "Desde Erfurt falo menos e atuo mais. E onde tenho que falar, penso mais o que no momento é tolerável ao partido. Só posso dizer que estou completamente satisfeito com o conseguido"509. Deste modo, a polêmica revisionista reuniu vários setores do partido que já aderiam e advogavam em prol de uma prática exclusivamente reformista em torno da defesa de Bernstein.

Assim como Vollmar, Viktor Adler defendeu a permanência de Bernstein no partido, manifestando seu apoio através de uma carta enviada a Bernstein em 17/3/1899, na qual reconhecera a existência de uma crescente corrente revisionista dentro do SPD $^{510}$ : "Eu direi a você e a todos francamente: em minha opinião você não se colocou em nenhum lugar fora da social-democracia, não importa o quanto eu discorde de você em algumas coisas. Você representa, de modo brilhante, uma corrente dentro do partido."

Discorrendo a respeito do Congresso de Hannover, Georg Bernhard Shaw realizou uma entusiástica manifestação de apoio ao revisionismo de Bernstein, que, a seu ver, nada mais seria do que uma revolta fabiana contra os velhos dirigentes ${ }^{512}$ da social-democracia alemã:

O informe da Fabian Society ao Congresso socialista internacional do ano de 1896 lhes mostrava que a luta que Bernstein iniciava naquele momento pela reforma do Partido Social-Democrata da Alemanha era uma luta que a Fabian Society já havia mantido e que já havia acabado felizmente na Inglaterra. Naturalmente que sou muito, muito bernsteiniano. Se Liebknecht quisesse tomar como base para seus discursos simplesmente sua própria tática Fabiana [grifo nosso] em vez das apaixonadas generalizações dos acontecimentos de 1848 e 1871 e o velho radicalismo revolucionário, deixaria claro para todo o mundo que em sua atividade parlamentar já praticou precisamente as modificações que parecem modificações do programa. Na Inglaterra se chama hoje social-democrata ao socialista que ficou sem esperanças atrás do curso dos acontecimentos. Também na Alemanha se poderia chegar a que

\footnotetext{
508 JOLL, James. La Segunda Internacional. Movimiento obrero 1889-1914. Barcelona: Icalia, 1976, p.91.

${ }^{509}$ De 28/10/1899 (Gustafsson, 1975, p.14).

${ }^{510}$ Bebel, igualmente percebe que "toda a questão seria de pouca relevância se houvesse apenas um Bernstein, mas nós temos um monte deles, e a maioria em posições importantes dentro do partido.”. (Bebel a Adler, carta de 8/4/1899) (Gay, 1970, p. 81).

511 Gay, 1970, p.181.

512 Ibid.
} 
essa apelação adquirisse o mesmo significado se o partido se mostra incapaz de adotar as idéias de Bernstein. ${ }^{513}$

De fato, a adesão ao reformismo e a procrastinação do projeto revolucionário para um futuro ainda longínquo e indeterminado, no qual as condições objetivas estariam maduras o suficiente para conduzirem ao colapso da sociedade capitalista e ao nascimento da nova sociedade socialista, não são colocados em questão pelos líderes social-democratas senão a partir de 1905. Até então, a discussão acerca da tática e meta socialistas, que contrapôs revolucionários e reformistas, havia se desenvolvido apenas no plano teórico, não repercutindo diretamente na reorientação da prática do SPD. Com a primeira insurreição russa e as rebeliões populares eclodindo em vários pontos da Europa, a mobilização dos trabalhadores para o enfrentamento revolucionário entra na ordem do dia.

Apesar de os líderes do partido terem combatido com afinco as teses revisionistas nos congressos de Lübeck ${ }^{514}$, em 1901, e Dresden, em 1903, no tocante à utilização da greve de massas como instrumento político revolucionário, tanto revisionistas ${ }^{515}$ quanto "ortodoxos" assumiram o mesmo posicionamento contrário. A aproximação entre o centro e a direita social-democrata alterou o espectro partidário. Paulatinamente, o reformismo galgou maior espaço e influência dentro do Partido Social-Democrata, sendo fortalecido pelos membros dos Sindicatos Livres, da burocracia do partido e da fração parlamentar.

O prestígio de Bernstein entre os setores reformistas do partido garantiu sua eleição para o Reichstag, como representante de Breslau, nas eleições de março de 1902. Bernstein recebeu 14.700 votos -3.000 votos a mais do que a soma de todos os outros ${ }^{516}$. A longa carreira parlamentar de Bernstein perpassou os períodos de 1902 a 1906, 1912 a 1918 e 1920 a 1928; contudo, não abdicaria de sua atividade jornalística, passando a escrever regularmente no órgão teórico dos revisionistas, Sozialistische Monatshefte, editado desde 1897 por Joseph Bloch.

A ascensão dos grupos revisionistas dentro do SPD levou Bernstein a intensificar suas críticas ao marxismo e a assumir abertamente sua identificação com os reformadores liberais

\footnotetext{
${ }^{513}$ Gustafsson, 1975, p.181.

${ }^{514}$ Discutiu-se no congresso o artigo de Bernstein “Como é possível um socialismo científico?”, escrito em 1901.

515 Cf. BERNSTEIN. "Political Mass Strike and Romanticizing Revolution". In: Selected writings of Eduard Bernstein: 1900 - 1921. New Jersey: Humanities Press, 1996, p.130-140.

${ }^{516}$ Gay, 1970, p.56.
} 
em seus artigos na revista Sozialistische Monatshefte ${ }^{517}$. Em 1904, na ocasião da publicação de um estudo sobre Lassalle, intitulado "Ferdinand Lassalle und seine Bedeutung für die Arbeiterklasse", ele escreve:

O julgamento de Lassalle que é expresso neste livro difere em muitos aspectos das opiniões que sustentei na introdução da coletânea de trabalhos de Lassalle [1891]. (...) Onde há diferenças, elas são conseqüência de um estudo mais aprofundado de Lassalle, assim como do fato de meu próprio desenvolvimento teórico ter me aproximado espiritualmente de Lassalle. ${ }^{518}$

Já em 1909, Bernstein apresentou ao partido um esboço de proposta para um novo programa que pudesse substituir o Programa de Erfurt. O novo programa - inspirado no programa minimalista do Parti Ouvrier francês - apresentaria dez pontos fundamentais, antecedidos por uma breve introdução com alguns princípios gerais ${ }^{519}$. Entre os instrumentos políticos de pressão abarcados pelo programa revisionista constam as coalizões políticas, as cooperativas de consumo e os sindicatos. Ademais, a liberdade de associação, o sufrágio universal democrático, o controle social da produção e a transferência de monopólios econômicos para o Estado são concebidos como precondições necessárias para a emancipação da classe trabalhadora no âmbito da sociedade capitalista.

Convém destacar alguns aspectos paradoxais referentes ao último ponto do documento apresentado por Bernstein, que apelava à solidariedade internacional proletária ao propugnar:

A luta da social-democracia não se limita a um único país, inclui todos os países modernos e civilizados. Solidariedade internacional entre trabalhadores, luta contra a exploração e dominação capitalista como a raiz de toda inimizade nacional. Internacionalismo, auto-determinação nacional, solidariedade e humanidade civilizada ${ }^{520}$.

Precisamente a defesa do internacionalismo socialista fora o fator que deu início ao seu distanciamento em relação a outros revisionistas, como Max Schippel, Wolfgang Heine, Gerhard Hildebrand, Eduard David, Friedrich Stampfer, Joseph Bloch, Carl Legien, Friedrich

\footnotetext{
${ }^{517}$ Como, por exemplo, "Idealismo, teoria da luta e ciência" (1901), "O cerne da disputa: uma resposta final à questão "como é possível um socialismo científico" (1901), "O culto a Marx e o direito de revisar" (1903), "De alguém pronunciado morto" (1905), "Classe e luta de classes" (1905), "Greve política de massas e a romantização da revolução" (1906). Cf. BERNSTEIN, E. Selected writings of Eduard Bernstein: 1900 - 1921. New Jersey: Humanities Press, 1996.

${ }^{518}$ Gay, 1970, p.68.

${ }^{519}$ BERNSTEIN, E. "Guiding principles for the theoretical portion of a Social Democratic Party Program". In: Selected writings of Eduard Bernstein: 1900 - 1921. New Jersey: Humanities Press, 1996, p.83-84.

${ }^{520}$ Ibid.
} 
Ebert, Gustav Noske, Ernst Heilmann e Philipp Scheidemann, que endossavam o militarismo e o expansionismo através de um discurso xenófobo e nacionalista.

Embora Bernstein tivesse apoiado a política colonialista do Império alemão ${ }^{521}$ a iminência de um conflito internacional levou-o a reconsiderar sua posição e aderir à campanha anti-militarista realizada pela ala revolucionária do partido e ao estabelecimento de redes de cooperação entre as nações civilizadas ${ }^{522}$. Neste sentido, em 1911, Bernstein escreveu o livro "O perigo inglês e o povo alemão" ("Die englische Gefahr und das deutsche Volk"), no qual criticava a propaganda nacionalista do governo contra a Inglaterra e a sua incorporação pela social-democracia. A seu ver, ao invés de ceder aos apelos militaristas dever-se-ia lutar pela conciliação das nações:

Aquele que reconheceu que o povo alemão não possui inimigo maior do que aqueles que constantemente declamam: "Inimigos, inimigos por todos os lados!" deve ousar lutar persistentemente pela criação de uma verdadeira liga pela paz das nações e pela realização da grande república popular. ${ }^{523}$

Apesar de sua oposição ao conflito entre as potências, ao estourar a guerra, em agosto de 1914, Bernstein aliou-se à ampla maioria do partido no Reichstag na aprovação dos créditos orçamentários destinados ao financiamento do combate. Com exceção de 14 deputados, dentre eles Karl Liebknecht, Georg Ledebour, Hugo Haase e Otto Rühle, os parlamentares do SPD anunciaram seu apoio ao que consideraram uma "guerra defensiva"

\footnotetext{
${ }^{521}$ Bernstein combateu as iniciativas propostas por Karl Liebknecht favoráveis a ações e propagandas antimilitaristas, durante as discussões do partido em 1907. Em artigo publicado na Sozialistische Monatshefte, intitulado "Patriotismo, militarismo e social-democracia" (julho de 1907), Bernstein defendeu a atitude de Bebel e Noske de repreensão à Liebknecht e condenou o uso de greves de massa contra ações militares. Sobre a propaganda anti-militarista Bernstein escreveu: "isto pode facilmente aumentar, ao invés de diminuir, o perigo que ele deseja afastar. É verdade que nem todo tipo de propaganda anti-militarista deve ser descartada. Militarismo é uma idéia muito ambígua. Se significa ser controlado pelos militares ou formar um exército separado do resto do povo por uma posição especial, então a social-democracia se opõe a isto desde que existe e continuará a se opor. (...) Mas se significa treinar o povo para manejar armamentos e preparar a nação para sua eficiente auto-defesa, que inclui a capacidade de, se necessário, expulsar o adversário do país, e de mantê-lo fora, então isto são coisas que a social-democracia nunca questionou e sempre defendeu" (Bernstein, "Patriotism, Militarism and Social-Democracy". In: www.marxists.org).

${ }^{522}$ A idéia de ampliação e expansão das relações internacionais foi visto por Bernstein de forma extremamente otimista: "agora que a dependência mútua das nações em todas as dimensões da vida social é já em grande parte realidade e está se ampliando, quando o estreitamento da rede de relações econômicas de todos os tipos está se alastrando no mundo civilizado, e jurisprudência, ciência, arte, política social estão se tornando mais internacionais, nos coloca na posição de realizar os deveres internacionais de um partido de trabalhadores e de um partido da paz com mais energia" (Bernstein, "Patriotism, Militarism and Social-Democracy". In: www.marxists.org).

${ }^{523}$ Gay, 1970, p.276.
} 
contra o czarismo e sua adesão à política de união nacional (Burgfrieden $)^{524}$. Esta capitulação da social-democracia alemã à política de guerra do governo imperial deixou claro às correntes revolucionárias o quanto o partido havia se afastado de seus princípios e ideais socialistas, encetando o processo que culminaria no inevitável cisma do partido.

Conquanto Bernstein tenha de início engrossado as fileiras do grupo majoritário contra o grupo de esquerda ${ }^{525}$ no tocante ao apoio à guerra, o autor não demonstrava absoluta convicção na posição assumida. Logo no mês seguinte ao início do conflito Bernstein desferiu uma série de críticas ao chauvinismo do partido e à anexação da Bélgica pelo Império ${ }^{526}$ que o indispuseram com seus partidários revisionistas. Seu isolamento foi evidenciado quando em setembro do mesmo ano Bernstein teve um artigo recusado na Sozialistische Monatshefte, no qual expunha seus argumentos contrários à propaganda anti-britânica difundida pelo governo. Como decorrência, em 10 de dezembro de 1914, Bernstein escreveu a Joseph Bloch:

Nós temos divergido durante algum tempo quanto à atitude que deve ser adotada pela social-democracia na questão das relações internacionais e nos problemas práticos da política internacional (...) Por esta razão eu não vejo necessidade de tratar deste assunto pessoalmente (...) Neste momento só daria ensejo a uma violenta discussão, já que eu me deixaria levar pelas emoções ${ }^{527}$.

Mesmo após o rompimento com seus companheiros revisionistas, Bernstein decidiu aprovar novamente os créditos de guerra em 2 de dezembro de $1914^{528}$. Somente em 20 de março de 1915, quando é novamente colocado em pauta no Reichstag, ele opta por abster-se da votação. A partir de então passa a pronunciar-se publicamente contra a guerra e à política anexionista alemã em artigos da Neue Zeit e Vorwärts. Em junho de 1915, Bernstein escreveu junto com Kautsky e Hugo Haase um manifesto intitulado "As exigências do momento",

\footnotetext{
${ }^{524}$ Em reunião, a fração parlamentar do SPD decidiu pelo apoio à guerra por 96 a favor e 14 votos contra. Cf. LOUREIRO, Isabel Maria. A revolução alemã, 1918-1923. São Paulo: UNESP, 2005, p.43.

${ }^{525}$ Em 1919, Bernstein refletiu sobre sua atitude no limiar da guerra: "Eu somente posso repetir o que eu disse no outono de 1914 em Berlim, (...) 3 e 4 de agosto foram os dias mais sombrias de minha vida política (...) a meu ver, nossos votos foram um desastre para o nosso próprio povo assim como para o mundo civilizado. Se disséssemos "não", como nós tínhamos o direito de fazer, ou se tivéssemos nos abstido (...) o povo alemão certamente não estaria tão mal como agora. Mas milhões de soldados não teriam sido mortos, milhões não teriam ficado incapacitados." (Gay, 1970, p.293).

${ }^{526}$ Cf. Gay, 1970, p.281.

${ }^{527}$ Gay, 1970, p.282.

${ }^{528}$ A bancada parlamentar do SPD tradicionalmente votava em bloco, conforme a decisão da maioria. Em 2 de dezembro de 1914 Karl Liebknecht rompeu pela primeira vez com a disciplina partidária e votou sozinho contra uma nova concessão dos créditos de guerra (Loureiro, 2005, p.44). A decisão de Liebknecht de opor-se aos créditos resultou em uma moção, proposta por Carl Legien, para sua expulsão da bancada por motivo de indisciplina. Tal proposta, no entanto, não foi acatada.
} 
condenando a crueldade da guerra e o expansionismo alemão, que fora publicado na Leipziger Volkszeitung.

A oposição de Bernstein à guerra, portanto, foi tornando-se gradativamente mais intensa. Se na votação de agosto de 1915 ainda absteve-se da aprovação dos créditos de guerra, na ocorrida em 29 de dezembro Bernstein finalmente votara contra a decisão da maioria da bancada parlamentar do SPD pela primeira vez. Com isto havia dado o primeiro passo na direção de seu desligamento do Partido Social-Democrata Alemão ${ }^{529}$.

Em 24 de março de 1916, em meio ao estado de sítio declarado pelo governo, a fração oposicionista - composta por dezoito representantes, dentre eles Bernstein - foi expulsa da bancada parlamentar, aumentando sua revolta em relação à Executiva do SPD. Durante o congresso do partido, em setembro do mesmo ano ${ }^{530}$, foi discutida mais uma vez a posição sustentada pela social-democracia perante a guerra e sua atitude para com a corrente antimilitarista. Na ocasião, os líderes do partido apresentaram à votação um texto redigido por Eduard David, intitulado, "Manifesto sobre a Paz", que declarava apoio à política de guerra do governo fundamentando-se no dever de defesa nacional contra os "inimigos do povo alemão”. Tal manifesto foi aprovado por dois terços do partido.

Como resposta à resolução, Bernstein escreveu o artigo "Crítica ao 'Manifesto sobre a Paz' da social-democracia alemã" na Neue Zeit, onde asseverara que a social-democracia deveria reafirmar sua oposição ao expansionismo imperialista e se ater à defesa de relações internacionais baseadas em princípios democráticos de autodeterminação nacional e de solidariedade internacional do proletariado. Segundo o autor, o dever de defesa nacional seria tão auto-evidente quanto o de salvar vidas humanas, sendo estes "princípios éticos fundamentais que não necessitam de ênfase em uma retórica especial”,531.

Seu artigo criticara ainda o fato de o partido ter assumido a linguagem de um partido governista - apesar de a social-democracia se encontrar excluída da política de guerra do governo imperial - com concepções de paz e guerra que lembram a dos partidos burgueses e termos como "povo" que excluem a noção de classe social. Por fim, Bernstein advertira que

\footnotetext{
${ }^{529}$ Cf. SCHORSKE, Carl E. German social democracy. 1905- 1917: The development of the great schism. New York: Harper Torchbooks, 1972.

${ }^{530}$ Realizado em Berlim, de 21 a 23/9/1916.

531 BERNSTEIN, E. "Critique of the German Social Democrat's Peace Manifesto". In: Selected writings of Eduard Bernstein: 1900 - 1921. New Jersey: Humanities Press, 1996, p.170.
} 
"para manter a coalizão de guerra com outros partidos burgueses, a social-democracia alemã renunciou aos seus mais importantes vínculos com o socialismo internacional" ${ }^{532}$.

Como foi visto, durante a guerra Bernstein pôde testemunhar a ascensão do revisionismo no seio do SPD e o seu resvalo para uma postura simultaneamente autoritária em termos partidários e complacente em relação ao governo imperial e às classes dominantes. Não obstante, sua ruptura com o partido em janeiro de 1917 foi realizada a contragosto, mediante as ordens da direção, liderada por Ebert e Scheidemann, para a expulsão da totalidade da ala oposicionista.

Bernstein, assim como Kautsky, ofereceu resistência à idéia de formação de um novo partido, temendo que este pudesse ser controlado pelos grupos radicais que viam na guerra a oportunidade de efetivar a revolução. Contudo, em abril de 1917, sob o impacto da Revolução Russa, foi criado o Partido Social-Democrata Alemão Independente (Unabhängigen Sozialdemokratischen Partei Deutschlands), tendo Bernstein ingressado em suas fileiras.

Quando em novembro de 1918 foi deflagrado o movimento insurrecional na Alemanha e estabelecido o governo provisório da nova república parlamentar, Bernstein passaria a clamar pelo entendimento e colaboração entre o SPD e o USPD ${ }^{533}$. As inúmeras e profundas divergências entre os dois partidos, no entanto, levaram o USPD a retirar-se do governo em 27 de dezembro. Bernstein, que havia ocupado o cargo de Secretário-Assistente (Beigeordneter) do Ministro do Tesouro, permaneceu no governo até fevereiro de 1919, após refiliar-se ao SPD.

A posição assumida por Bernstein durante os anos que se seguiram à chegada ao poder da ala majoritária da social-democracia na Alemanha colocaram em evidência todas as fragilidades e contradições de seu posicionamento político. Em um período extremamente favorável de vacância política, após a derrota da monarquia parlamentar e estabelecimento das instituições republicanas, Bernstein - acompanhando a ala majoritária do SPD - passa a advogar pelo refreamento das mudanças políticas, econômicas e sociais em nome da manutenção da ordem. O programa socialista é desconsiderado, dando lugar a uma política de moderação e conciliação com as velhas elites dirigentes do império: a alta burocracia, a burguesia e o oficialato.

Assim, da postulação pela implementação de uma democracia social, passara a exortar a contenção das massas populares e trabalhar contra a radicalização da revolução, conferindo

\footnotetext{
${ }^{532}$ Ibid, p.177.

${ }^{533}$ Cf. LOUREIRO, Isabel Maria. A revolução alemã, 1918-1923. São Paulo: UNESP, 2005, p. 67.
} 
apoio às medidas de repressão do movimento popular democrático, como a dissolução dos conselhos de trabalhadores e soldados, a conservação da estrutura conservadora do Exército e sua utilização como arma contra-revolucionária.

Sua defesa da república parlamentar contra os "perigos" do "revolucionarismo bolchevique" procurava justificar assim a atitude do governo social-democrata, liderado por Ebert, em relação aos grupos oposicionistas. Não obstante ter criticado o alto grau de violência perpetrada sob o comando do Ministro da Guerra, Gustav Noske, na repressão militar contra seus ex-companheiros de partido no início de 1919, Bernstein fazia coro à opinião difundida pela imprensa que considerava tal movimento insurrecional como uma tentativa de golpe bolchevista.

Para o autor, a possibilidade de instauração de um governo nos moldes bolchevistas seria algo inadmissível, a ser evitado a todo custo. Bernstein via o governo revolucionário na Rússia como uma extensão do despotismo czarista:

O bolchevismo é um fenômeno específico da Rússia que deriva de longos séculos de absolutismo e habituação com o pior tipo de opressão. Ele definitivamente não serve como modelo a ser imitado. Bolchevismo é o melhor exemplo dos terríveis efeitos de uma teoria errônea, cego às leis fundamentais da sociedade e desconsideração pelos princípios evolucionistas que guiam os seres humanos da barbárie à civilizaçãa ${ }^{534}$.

Em sua opinião a política bolchevique seguiria um curso desastroso causado pela ignorância das leis econômicas, pela desconsideração das condições materiais e ideais do processo econômico e pela cegueira às funções das instituições econômicas. Seus planos relativos à educação, ao bem-estar-social, à distribuição e organização da produção e à utilização de recursos naturais não sairiam do papel em virtude da ausência de precondições materiais necessárias e de um proletariado educado. Deste modo, Bernstein condenava os bolcheviques por trazerem a desordem ao eliminarem as livres forças do mercado, que, em sua visão, seriam essenciais à recuperação econômica ${ }^{535}$.

A Revolução Russa teria ocasionado ainda a queda de $25 \%$ da população das cidades, aumentado a miséria, criado uma vasta e poderosa burocracia que regeria o Estado e a produção industrial e suprimido as liberdades políticas, levando à opressão da classe

\footnotetext{
${ }^{534}$ BERNSTEIN, E. "The Bolshevist Brand of Socialism”. In: Selected writings of Eduard Bernstein: 1900 1921. New Jersey: Humanities Press, 1996, p.190. Artigo publicado em Der Sozialismus Einst und Jetzt, em 1921.

${ }^{535}$ Ibid, p. 189.
} 
trabalhadora. Em suma, Bernstein dirigiu à ditadura do proletariado severas críticas e repreensões a seus métodos e objetivos, enquanto, simultaneamente, via como legítima a violência praticada contra os social-democratas em seu próprio país, em nome da república parlamentarista burguesa.

Bernstein considerava que a rebelião na Rússia e a revolta na Alemanha seriam tão diferentes em sua natureza e em sua ideologia que seria quase impossível defini-las pela mesma palavra: "revolução". Neste sentido, em artigo na revista Justice, de 7 de dezembro de 1922, escrevera: ${ }^{.36}$

Em 7 de novembro, houve um típico coup d'état, que, acredito, pode ser definido como uma "revolução" apenas no sentido daqueles atos de violência nos países asiáticos que resultam em uma mudança de regime (...) em sua essência foi uma rebelião efetuada com o auxílio de brutos soldados não-educados politicamente - a rebelião contra a Revolução e contra os acontecimentos revolucionários.

O autor interpreta, portanto, a Revolução Russa como um golpe sobre a verdadeira revolução - a burguesa - realizada por um partido despótico que teria conseguido manter-se no poder através de uma ditadura militar. Segundo o autor, a supressão de toda vida intelectual e o extermínio de toda imprensa independente revelariam maior proximidade com o velho czarismo do que com qualquer outro partido que tenha tomado parte na revolução de 1905. Por mais honestos que fossem os objetivos dos líderes do coup d'etat, estariam criando em seu próprio país uma nova ordem capitalista que diferiria da anterior apenas por seu nível inferior de cultura.

A seu ver, portanto, a história nunca daria o nome de revolução a esta rebelião, posto que os bolcheviques teriam subjugado "um grande país à escravidão espiritual e moral". Diferentemente, a revolta na Alemanha teria propiciado maior liberdade política aos trabalhadores alemães, não importando o partido a que eles pertencessem, e, conseqüentemente, poderia ser definida como uma "revolução", no próprio sentido da palavra:

A nova situação política criada na Alemanha em 9 de novembro de 1918 ainda não realizou aquilo que era esperado pelos muitos participantes destes acontecimentos. A República Alemã estabelecida pelos trabalhadores de Berlim não é uma república operária. E se não é uma república da burguesia, ela ainda permanece uma república burguesa no antigo sentido democrático da palavra. Contudo, não é apenas na forma que a

${ }^{536}$ BERNSTEIN, E. “On the Russian and German Revolutions". In: www.marxists.org. 
presente república se diferencia do antigo Império. No tumultuado novembro de 1918, não somente tronos foram esmagados e coroas despedaçadas: naqueles dias as cadeias que impediam o futuro desenvolvimento do movimento operário foram quebradas. A revolução deu aos trabalhadores alemães não apenas direitos políticos, mas melhorou suas condições sociais $^{537}$.

Embora Bernstein tenha se reintegrado ao partido e se posicionado ao lado do governo - sendo novamente eleito para ocupar uma cadeira no Reichstag em 1920 - a sua influência sobre o SPD havia declinado consideravelmente. Sua oposição à guerra lhe garantiu o dissabor do grupo direitista e seu repúdio à via revolucionária conduziu-o a definitivamente cortar relações com a esquerda. Mesmo assim, em 1921, Bernstein foi convidado a tomar parte na redação do Programa de Görlitz, que substituíra o Programa de Erfurt, de $1891^{538}$. O novo programa trazia um conteúdo reformista e moderado, destinado a transformar o SPD de um partido proletário em um "partido do povo trabalhador"

Visando à clara diferenciação em relação aos social-democratas de esquerda, o programa declarava que qualquer atentado contra a república democrática seria concebido como uma ameaça aos direitos fundamentais do povo. Previa ainda como metas a concessão de maior poder às municipalidades e comunidades locais, a descentralização do poder, a criação de uma burocracia permanente e profissional e o planejamento racional de um coletivismo pragmático, capaz de oferecer o melhor bem-estar econômico, político e moral possível a todos. Através de reformas pacíficas e legais seria alcançada a crescente igualdade econômica e estendida a cidadania a todos.

Entre as políticas sociais, recebiam destaque as questões relativas à nacionalização parcial da economia, ao seguro social, à moradia, à alimentação, à ampliação das possibilidades legais de expropriação, e à conservação de um Estado democrático e representativo. Apesar de o programa ter expressado a concepção hegemônica no partido, em 1925 o SPD adotou um novo programa mais à esquerda - conhecido como o Programa de Heidelberg - no intuito de atrair os membros anti-bolcheviques do USPD e afastá-los do Partido Comunista Alemão (KPD).

\footnotetext{
537 Ibid.

${ }^{538}$ O programa foi aprovado em 23 de setembro de 1921.

539 Assim é apresentado o programa: "Die Sozialdemokratische Partei Deutschlands ist die Partei des arbeitenden Volkes in Stadt und Land. Sie erstrebt die Zusammenfassung aller körperlich und geistig Schaffenden, die auf den Ertrag eigener Arbeit angewiesen sind, zu gemeinsamen Erkenntnissen und Zielen, zur Kampfgemeinschaft für Demokratie und Sozialismus" (Sozialdemokratische Partei Deutschlands das Görlitzer Programm, in: www.marxists.org).
} 
Em outubro de 1923, com a morte de sua esposa, Bernstein, com setenta e três anos, passa a sentir com maior intensidade o peso de seu isolamento político. Ressentia-se, sobretudo, do desdém manifestado pelos membros do partido na rejeição de inúmeros artigos seus em periódicos como o Gesellschaft, editado por Rudolf Hilferding e Vorwärts, publicado por Friedrich Stampfer. A partir de então, sua saúde passa a se deteriorar, tendo sofrido dois derrames em 1925. Em 1928 se afastou do trabalho parlamentar e passou a dedicar-se inteiramente ao jornalismo e à participação em cursos e conferências.

Deste modo, Bernstein dedicou os últimos anos de sua vida a alertar a socialdemocracia para os diferentes "perigos" que cercariam a República de Weimar: o bolchevismo, o ultra-nacionalismo de direita e o pragmatismo do próprio partido - que cada vez mais estaria concentrado nas vitórias eleitorais sem se preocupar com a educação política das massas trabalhadoras.

Apenas seis meses antes de Adolf Hitler assumir o poder, no dia 18 de dezembro de 1932 Bernstein morre em Berlim. Por mais controversas que tenham sido suas teses, por mais censuráveis que tenham sido as posições políticas assumidas ao longo de sua vida, a relevância de Bernstein na trajetória da social-democracia alemã é inegável, sendo um dos principais protagonistas políticos de seu tempo.

\section{2- A revisão do marxismo}

Como pudemos verificar através da análise da trajetória política de Bernstein, seus posicionamentos básicos não sofreram uma reviravolta radical, como querem nos fazer crer muitos estudiosos de seu pensamento ${ }^{540}$. As incongruências e ambigüidades presentes desde o início de seu percurso intelectual, marcado predominantemente por uma evidente inclinação ao ecletismo e ao antidogmatismo, já sinalizavam para o fato de que Bernstein não adotaria, ao longo de sua vida, um viés teórico estritamente marxista.

\footnotetext{
${ }^{540}$ Bo Gustafsson (1975, p.115) identifica como momento marcante desta ruptura o comentário e epílogo elaborados por Bernstein em 1895/1896 para a edição alemã do livro "História da Revolução Francesa de 1848", de Louis Héritier. Nestes escritos Bernstein realiza uma dura crítica aos insurretos, opondo-se radicalmente à interpretação de Marx exposta em "A Luta de Classes na França - de 1848 a 1850". Contudo, na literatura a versão mais corrente localiza a "conversão" de Bernstein ao revisionismo ainda no ano de 1896, na série de artigos reunidos sob o nome "Problemas do Socialismo", publicados pela Neue Zeit (Gay, 1970; Fetscher, 1982; Kolakowski, 1985; e Schorske, 1972).
} 
Seja no âmbito de sua atividade jornalística, de seus escritos teóricos ou de sua atuação partidária e parlamentar, Bernstein declarava-se acima de doutrinas e alinhamentos políticos, assinalando seu compromisso com a verdade. Compreendida como princípio científico, a verdade seria instrumento fundamental à orientação da prática política voltada para a produção de resultados. Consoante argumentara em "O novo desenvolvimento das relações agrárias na Inglaterra", artigo escrito em 1896, mesmo não sendo algo sempre agradável a verdade seria útil e indispensável, pois nos ensinaria a voltarmos forçosamente nossa atenção para as tarefas que podemos efetivamente resolver, afastando-nos do imobilismo derivado de idéias que não se encontram amparadas na realidade ${ }^{541}$.

Como na doutrina positivista, a "verdade" apurada cientificamente seria o antídoto contra a contaminação pelo utopismo e por outras mistificações a que os indivíduos estariam sujeitos. Dentre estas mistificações encontrar-se-ia ainda o culto a personalidades. Ao propugnar que o interesse da "grande causa" não poderia ser ofuscado pela glória de um único indivíduo, Bernstein alertava que a social-democracia não deveria possuir lendas nem fazer de seus precursores "santos". Tais personalismos e glorificações impediriam a submissão dos líderes e expoentes da social-democracia à devida análise crítica ${ }^{542}$ tanto no plano teórico quanto no plano das ações político-organizativas.

Tendo isso em vista, Bernstein realizou em seu estudo biográfico sobre Ferdinand Lassalle, escrito entre 1889 e 1890, uma incisiva censura ao culto erigido ao seu redor, promovido por discípulos como Hasselmann, Hasenclever e Tölcke - responsáveis, em sua concepção, pela conversão da Associação Geral dos Trabalhadores Alemães em uma espécie de "seita" 543 . Se nesta fase contava ainda com o relevante apoio e orientação de Engels na tarefa de dessacralizar a figura de Lassalle - e assim minar a influência deste sobre o movimento operário - em apenas alguns anos Bernstein voltou suas armas em direção ao arcabouço teórico marxiano.

Mesmo não sendo possível ou apropriado determinar no tempo o momento preciso do "desvio teórico" bernsteiniano em direção ao revisionismo, pode-se facilmente constatar que no final da última década do século XIX, sobretudo após a morte de Engels em 1895,

\footnotetext{
541 BERNSTEIN. "Problemas del socialismo". 1896-1897. In: Las Premisas del socialismo y las tareas de la socialdemocracia. Problemas del socialismo. El revisionismo en la socialdemocracia. México: Siglo Veintiuno, 1982 , p.39.

542 BERNSTEIN, Eduard. Ferdinand Lassale: le réformateur social. Paris: Marcel Rivière, 1913, p.227.

${ }^{543}$ Ibid, p. 226.
} 
Bernstein passou a dedicar-se com maior afinco à tarefa de sublinhar e esclarecer seus pontos de discordância em relação ao marxismo oficial do partido.

Embora suas críticas fossem endereçadas à direção do Partido Social-Democrata Alemão - que a seu ver seria responsável por obstaculizar o progresso prático da socialdemocracia através da adoção intransigente de fórmulas rígidas preestabelecidas, oriundas da doutrina marxista -, Bernstein passou a defender a polêmica proposta de elaboração de uma ampla e profunda revisão das teses fundamentais de Marx e Engels, no intuito de oferecer fundamentos teóricos à prática reformista.

Recorrendo tanto à tradição socialista precedente, como é o caso de Proudhon, quanto a autores declaradamente liberais, como Lujo Brentano e Julius Wolf, e escorando-se ainda na análise de dados empíricos relativos ao progresso da economia alemã provenientes do censo industrial de 1895, Bernstein pretendia apontar erros e contradições nos ensinamentos dos pais fundadores do socialismo científico, desferindo sérios ataques contra a teoria do colapso, a teoria da concentração do capital, a teoria da polarização das classes, a teoria do depauperamento do proletariado, a teoria do valor e a própria concepção materialista da história.

Com efeito, o revisionismo socialista, "com base na ciência e nas exigências da luta prática" ${ }^{444}$, procurava enxergar as mudanças políticas, econômicas e sociais geradas no seio da sociedade capitalista, investigar suas conseqüências e atestar seu impacto sobre a teoria marxista, a fim de determinar quais conclusões e pressuposições da doutrina teriam se tornado obsoletas frente ao desenvolvimento histórico subseqüente.

Em resumo, conquanto anunciasse sua filiação à tradição marxista, o empreendimento teórico bernsteiniano possuía claros objetivos práticos: extirpar do programa político da social-democracia os elementos considerados indesejáveis e ultrapassados constantes do projeto socialista, expor a divergência entre os meios e os fins defendidos pela ala "ortodoxa" e fundar alicerces teóricos que servissem de sustentação à tática gradualista, já defendida por diversos segmentos do partido.

Opondo-se ao dogmatismo imperante entre os membros da "ortodoxia" - que, de acordo com Bernstein, privaria a teoria marxista de seu genuíno caráter científico ao transformá-la em uma "sectária profissão de fé" 545 - asseverava que qualquer teoria socialista

\footnotetext{
544 BERNSTEIN. "The Marx cult and the right to revise". In: Selected writings of Eduard Bernstein: 1900 1921. New Jersey: Humanities Press, 1996, p.46. Artigo publicado pela Sozialistische Monatshefte, em 1903. ${ }^{545}$ Ibid, p. 45.
} 
que clamasse aderir aos imperativos do método científico deveria admitir invariavelmente a necessidade de revisão da construção marxiana. Sendo assim, um culto a Marx seria justificado apenas enquanto permanecesse no estrito limite da razão e do método científico.

Os primeiros esforços do autor no sentido de realizar uma ampla revisão da teoria marxista foram efetuados por intermédio de uma série de artigos intitulados "Problemas do Socialismo"546 publicados na Neue Zeit entre 1896 e 1898 e desenvolvidos, a pedido de Karl Kautsky e Viktor Adler, no livro "Os Pressupostos do Socialismo e as Tarefas da Socialdemocracia”, em $1899^{547}$. Nestes escritos, Bernstein dedica-se a compor os princípios basilares do revisionismo, aos quais manteve-se fiel até o final de sua vida ${ }^{548}$. Seu objetivo primordial consistia na refutação da teoria do colapso, propagada, ainda que de modo paradoxal, pelos líderes da social-democracia alemã e firmada na parte teórica do Programa de Erfurt. Estes aliavam à prática imediatista de luta por reformas políticas e econômicas uma confiança inabalável na iminente derrocada final do capitalismo resultante do agravamento das crises econômicas, conforme Marx e Engels haviam propugnado.

Bernstein, ao contrário, opunha-se frontalmente à idéia de que a sociedade burguesa estivesse à beira de um colapso. De acordo com sua perspectiva evolucionista, a economia capitalista teria desenvolvido inúmeros mecanismos de adaptação que a teriam tornado praticamente imune a crises econômicas gerais. Deste modo, todas as previsões marxianas relativas às conseqüências funestas da lei geral da acumulação capitalista - a concentração do capital, a queda tendencial da taxa de lucro, a expansão do exército industrial de reserva, o agravamento do pauperismo e a polarização das classes, isto é, os fatores que desvelariam o caráter contraditório da acumulação capitalista - estariam, para Bernstein, sob muitos aspectos, superadas.

Seu diagnóstico, no entanto, explora de modo ligeiro e superficial a nova faceta apresentada pelo capitalismo em sua fase expansionista. Limita-se a enunciar os efeitos produzidos pelas mudanças circunstanciais, que em sua análise ganham caráter definitivo e invariável. Nestes termos, o largo e contraditório processo histórico de expansão industrial atravessado pela Alemanha a partir de meados do século XIX assume, na otimista e

\footnotetext{
${ }_{546}^{546}$ Ver seção 3.1 .

${ }^{547}$ Ao tempo da publicação do respectivo livro, as teses de Bernstein já haviam sido rechaçadas e condenadas no Congresso do Partido Social-Democrata Alemão, em Stuttgart, realizado em 20/10/1898.

${ }^{548}$ Não observamos uma mudança substancial entre o pensamento de Bernstein até 1899 , quando escreve "Os Pressupostos...", e seu pensamento após 1900. Deste modo, não aderimos à conceituação proposta por Manfred Steger (1997) que faz a diferenciação entre o "revisionismo de juventude" e o "revisionismo maduro" de Bernstein.
} 
problemática análise bernsteiniana, o caráter de processo civilizador, no qual a sociedade dirigir-se-ia progressiva e linearmente no sentido da maior estabilidade, organização e harmonia social.

Deste modo, sua predição entrevê no âmbito da própria sociedade capitalista a passagem da anarquia da produção ao controle social a cargo do Estado, a suplantação da reificação das relações sociais e da alienação do trabalho pelo despertar moral de todas as classes sociais e a substituição da luta de classes pela cooperação geral.

\subsection{1- Bernstein e o desenvolvimento do capitalismo moderno}

Entre os intelectuais evocados por Bernstein no intuito de fornecer bases teóricas à sua revisão há que se ressaltar a preeminente influência exercida pelo economista John Atkinson Hobson $^{549}$. Embora Bernstein tenha constantemente reafirmado seu distanciamento político e ideológico em relação aos socialistas fabianos ${ }^{550}$, sua afinidade com Hobson foi por ele assumida em mais de uma ocasião. Uma breve análise da teoria esboçada por Hobson em uma de suas obras de maior repercussão, "A evolução do capitalismo moderno",551 - primeiramente publicada em $1894^{552}$ - revela quão próximo Bernstein estava de suas idéias e a grande dívida que possuía para com o autor, no que concerne à estruturação e fundamentação de sua doutrina revisionista.

Em seu livro, Hobson investiga a dinâmica interna em curso nas sociedades industriais avançadas, particularmente verificada na Inglaterra e nos Estados Unidos. Deste modo, o autor pretende apreender e explicar tanto os efeitos produzidos em função do desenvolvimento dos métodos industriais modernos (como, por exemplo, a aplicação geral da

\footnotetext{
549 John A. Hobson (1858-1940), economista e jornalista inglês vindo da classe média, adotava uma postura teórica que alcunhava de "humanismo econômico", com forte influência de John Stuart Mill, Herbert Spencer e Werner Sombart (principalmente de sua obra "Der Moderne Kapitalismus"). Participou de movimentos liberais como a Sociedade Ética de Londres e mais tarde aproximou-se da Sociedade Fabiana (TEIXEIRA, A. Utópicos, heréticos e malditos. Rio de Janeiro: Record, 2002, p.413-414).

${ }^{550}$ Segundo Maria da Conceição Tavares, em sua apresentação ao livro "A evolução do capitalismo", Hobson é habitualmente considerado um marxista fabiano, embora tenha sofrido influência de diversas correntes de pensamento, de Marx a Sombart e Veblen, tendo criado uma longa carreira como economista "vigoroso, criativo e essencialmente herético" ( Hobson, 1983, p.VII).

551 "The evolution of modern capitalism: a study of machine production". Ver HOBSON, John A. "A evolução do capitalismo moderno: um estudo da produção mecanizada". In: Os economistas. São Paulo: Abril Cultural, 1983.

552 Convém destacar a sua reedição em 1906, na qual Hobson introduz um estudo detalhado acerca do processo de concentração na indústria moderna, utilizando como exemplo os Estados Unidos, e do papel desempenhado por financistas. Em seu prefácio o próprio autor atesta que os acréscimos e alterações são tão significativos que constituem efetivamente um novo livro (Hobson, 1983, p.3).
} 
maquinaria e do motor à vapor na produção) quanto o processo de progressiva concentração e combinação do capital, expresso pelo surgimento de cartéis e trustes em vários ramos da economia. Além disto, Hobson ressalta ainda o papel desempenhado pelos capitalistas financeiros - resultantes da fusão de interesses do capital industrial com o bancário - sobre a indústria, promovendo a ampliação do grande capital monopolista ${ }^{553}$ e a expansão do comércio internacional.

Hobson, todavia, não associava a concentração do capital na indústria moderna, representada pelo crescimento das fusões, trustes e cartéis, com o declínio da taxa geral de lucro ${ }^{554}$. Ao contrário, considerava a força expansiva da produção e dos mercados o prenúncio de um aumento significativo da margem de lucro das empresas. A concentração e a monopolização em certos setores tampouco fariam desaparecer por completo a concorrência, proporcionando um novo impulso à produção especializada, desenvolvida a nível local nas pequenas cidades e distritos agrários. Assim, a produção em larga escala da grande empresa que introduz novos métodos de produção seria responsável pela expansão e unificação do mercado.

Em suma, de acordo com o autor, a diferenciação, integração e interdependência dos mercados (empresas e indústrias) assegurariam a sobrevivência das pequenas empresas perante a produção em grande escala. Sob este prisma, ainda que o sistema capitalista coloque sob o controle de um punhado de proprietários um número crescente de negócios e processos, estabeleceria, em contrapartida, ligações comerciais e unidade de interesses entre uma diversidade de empresas, negócios e mercados que se manteriam em pleno funcionamento.

A perspectiva hobsoniana, no entanto, enxerga na sociedade industrial moderna um desajuste econômico estrutural, manifesto nos seguintes termos:

O desenvolvimento real de riqueza material, apesar de grande, não tem sido absolutamente proporcional às potencialidades imensamente acrescidas de produção de bens materiais, propiciadas pelas descobertas da ciência moderna; e a utilização parcial dessas descobertas vem sendo acompanhada por uma distribuição muito desigual das vantagens desse aumento no

\footnotetext{
${ }^{553}$ Hobson, assim, alerta contra o papel dominante que exercem os banqueiros nas sociedades industriais avançadas, na medida em que são convertidos em uma classe especial de financistas que tendem a parasitar sobre a indústria. "Como o crédito se converte cada vez mais na força vital dos negócios modernos, a classe dos que controlam o crédito torna-se mais poderosa e embolsa como "ganhos" um percentual maior do produto industrial” (Hobson, 1983, p.188). Ver capítulo X, "O financiador" (ibid, p.175-200).

${ }^{554}$ Consoante Marx (1985b, p.163-176), em “O Capital”, a mudança na composição orgânica do capital em todas as esferas da produção decisivas (com o crescimento do capital constante em relação ao variável), típico das grandes empresas, resultaria em uma queda gradual na taxa de lucro geral.
} 
que se refere ao acervo de conhecimento geral e controle da natureza ${ }^{555}$.

Segundo Hobson, portanto, a rapidez e a irregularidade da descoberta e aplicação dos novos métodos de produção impediram o ajustamento imediato da estrutura da ordem social às novas condições tecnológicas. Logo, a excessiva utilização de maquinarias é concebida pelo autor como o fator responsável pelo surgimento de inúmeras enfermidades materiais e morais que prejudicariam a "saúde" das sociedades industriais modernas. Neste sentido, desloca-se mais uma vez as origens das deficiências e contradições produzidas no âmbito do modo de produção capitalista das formas históricas de relações sociais nela atuantes para as máquinas, que desta maneira ganham o status de categoria econômica - o que já havia sido analisado por Marx em sua crítica à teoria proudhoniana ${ }^{556}$.

Este desajuste ocasionado pela introdução de mais máquinas na produção, no entanto, estaria, na visão de Hobson, fadado ao desaparecimento. Aderindo a uma perspectiva evolucionista inspirada em Herbert Spencer, o autor afirma que a sociedade estaria caminhando lenta e progressivamente rumo ao seu reajuste. Esta "adaptação natural" poderia ser acelerada através da ação consciente e reguladora da sociedade que, assim, remediaria os males e defeitos da indústria moderna e asseguraria à humanidade os "usos, sem os abusos, da maquinaria",557.

Como a tendência geral da indústria, na medida em que se submete a economias modernas de maquinaria e método, é tender para a concorrência ruinosa ou para o monopólio, devese esperar que haja uma expansão contínua da interferência do Estado e do volume de seus empreendimentos. Essa crescente socialização da indústria deve ser considerada como um ajustamento da sociedade às novas condições da produção mecanizada $^{558}$.

O progresso rumo a uma organização industrial estável e coerente, apta a proporcionar o bem-estar geral, implicaria a adoção de formas de controle social sobre a produção, seja através da imposição de uma legislação restritiva - consubstanciada nos dispositivos governamentais de proteção contra males de ordem econômica e contra abusos aos

\footnotetext{
${ }^{555}$ HOBSON, John A. "A evolução do capitalismo moderno: um estudo da produção mecanizada". In: Os economistas. São Paulo: Abril Cultural, 1983, p.300.

556 "A máquina tem tão pouco de categoria econômica quanto o boi que puxa o arado. A atual utilização das máquinas pertence às relações de nosso atual sistema econômico, mas o modo como as máquinas são exploradas é algo totalmente diverso das próprias máquinas" (Marx, Engels, 1983, p.435). Carta de Marx a P. V. Annenkow, 28 de dezembro de 1846.

${ }_{557}$ Hobson, 1983, p.303.

${ }^{558}$ Hobson, 1983, p.304.
} 
consumidores - seja mediante a encampação de empresas e indústrias em ramos estratégicos da economia. A passagem de vários segmentos da indústria (tais como o dos transportes terrestres e hidroviários, o dos correios e telégrafos, o das minas de carvão e minério de ferro, o das companhias de água, gás e eletricidade, e até no tocante às terras ${ }^{559}$ ) e dos serviços básicos (como a educação, a saúde pública, a assistência judiciária, a cultura e a recreação) para as mãos do governo federal ou municipal, daria lugar a um "coletivismo limitado" 560 , determinado pela conveniência social.

A solução apontada por Hobson - e posteriormente retomada por Keynes - tem como pressuposto a idéia de que cabe à sociedade a salvaguarda do interesse público ${ }^{561}$ em detrimento dos interesses egoísticos particulares ${ }^{562}$. As limitações à liberdade individual no âmbito da indústria e a contestação dos princípios do laissez faire, entretanto, não prenunciariam a desaparição do sistema capitalista. Hobson coaduna em sua teoria o controle público da produção mecanizada com a implementação de reformas que visem ao livre comércio e à livre-concorrência ${ }^{563}$, propiciando o rompimento de todas as barreiras que obstruem o livre fluxo do comércio, a migração de capital e mão-de-obra e a ampla difusão de informações sobre a indústria ${ }^{564}$. Como explica Maria da Conceição Tavares, em Hobson

a liberdade de competição e de iniciativa particular na indústria e no comércio das empresas vai a par com a ênfase no caráter público e socialista que devem ter os grandes monopólios. Estes são considerados como uma etapa necessária de transição para libertar os homens das necessidades mais prementes, que não se

\footnotetext{
${ }^{559}$ Hobson advoga que também as terras devem estar sujeitas ao controle do Estado (restringindo-se o seu uso privado), de modo que este assegure o atendimento dos interesses públicos.

${ }^{560}$ Para Hobson existem dois tipos de indústrias que apresentam caráter coletivo: aquelas que em função de seu tamanho e estrutura não oferece proteção ao público consumidor (monopólios) e aquelas nas quais o desperdício e os prejuízos decorrentes da competição pesam mais que as perdas empresariais ("concorrência ruinosa"). Deste modo, as indústrias só tenderiam a passar para a administração pública quando o objeto do monopólio fosse um artigo de consumo geral e indispensável, e onde a elevação de preços não conseguisse encorajar uma competição efetiva (Hobson, 1983, p.303-304).

561 "Muitas, senão a maioria, das grandes catastrofes das sociedades mercantis modernas podem ser atribuídas precisamente ao fato de que o crédito das grandes empresas mercantis, que é sobretudo uma questão de interesse público, antes da bancarrota é considerado como puramente privado" (Hobson, 1983, p.301).

562 "A necessidade de um controle social crescente sobre a produção mecanizada moderna, quando a produção fica, no fundamental, sob a direção de empreendimento individual, é reconhecida por todos, embora o desenvolvimento desse controle tenha sido desigual e determinado pela pressão de injustiças flagrantes e não referendado por qualquer teoria específica de responsabilidade pública" (Hobson, 1983, p.303).

563 "A diafaneidade perfeita das operações industriais, a perfeita fluidez do trabalho e da riqueza realizariam economias imensamente grandes na criação de riqueza comercial" (Hobson, 1983, p.301).

564 "Na complexidade do intercâmbio comercial moderno, deve-se reconhecer que não há lugar para esse "interesse exclusivo" ou atividade reservada. Nenhum fato relacionado com preços, salários, lucros, métodos de produção etc., afeta somente uma única firma ou um único contingente de operários” (Hobson, 1983, p.301).
} 
deriva nem se compadece automaticamente com o livre comércio $^{565}$.

Consoante o autor, a nova sociedade em vias de construção seria "socialista" na produção dos bens em grande escala (que afetam o consumo das massas), mas "individualista e criativa" em relação ao fornecimento de bens vinculados ao lazer, à arte e à produção intelectual. A sociedade, portanto, seria configurada pela existência de grandes empresas e indústrias de propriedade estatal, caracterizadas pela produção em série de bens e insumos socialmente relevantes, e uma grande variedade de pequenas empresas cuja produção seria individualizada e qualitativamente diferenciada. A sobrevivência destes pequenos negócios, vitalizados por atributos individuais, exigiria, no entanto, o aprimoramento da qualidade do consumo. A correção do consumo e o combate à "paixão pelo consumo quantitativo", que sufocaria a personalidade dos consumidores com produtos padronizados e homogeneizados, seria, a seu ver, suficiente para afastar a lei dos rendimentos decrescentes.

A similaridade entre a formulação teórica hobsoniana e o reformismo bernsteiniano é evidente. É possível perceber o alcance de sua influência já nos primeiros escritos assumidamente revisionistas de Bernstein, publicados a partir de 1896. Bernstein chega a dedicar um artigo inteiro na Neue Zeit à análise do livro de Hobson, publicado sob o título "Uma teoria sobre os domínios e limites do coletivismo"566. Neste, Bernstein valida a perspectiva reformista do autor e endossa suas teses acerca dos limites naturais do coletivismo:

Se não estamos de acordo com diferentes detalhes das explicações de Hobson, nos parece que a idéia fundamental das mesmas é irrefutável. De todo modo, por muito tempo temos que nos desembaraçar da idéia de que nos aproximamos de um estado social totalmente coletivista. Temos que nos familiarizar com a idéia de uma comunidade coletiva parcial ${ }^{567}$.

Calcando-se nos conceitos de "socialismo progressivo" ou de "socialismo viável", esboçados por Hobson, Bernstein encontra bases para a sua crítica ao que considera "o caráter utópico do socialismo" e à "esterilidade" da tática revolucionária, a qual retornará em seu livro de 1899, "Os pressupostos do socialismo e as tarefas da social-democracia".

\footnotetext{
${ }^{565}$ Hobson, 1983, p.X.

566 "Eine Theorie der Gebiete und Grenzen des Kollektivismus".

${ }^{567}$ BERNSTEIN. "Una teoría sobre los limites del colectivismo". 1896-1897. In: Las Premisas del socialismo y las tareas de la socialdemocracia. Problemas del socialismo. El revisionismo en la socialdemocracia. México: Siglo Veintiuno, 1982, p.18.
} 
Seguindo fielmente o modelo formulado por Hobson, Bernstein tenta reproduzir ponto por ponto a análise do autor, desta vez aplicada à situação da Alemanha. Através do estudo comparativo das estatísticas fornecidas pelos censos industriais de 1882 e $1895^{568}$, Bernstein constatou que o número de possuidores na Alemanha crescera consideravelmente, acompanhando o enorme incremento da riqueza social. Partindo deste fato, deduz que a sociedade alemã não estaria assistindo a um processo de concentração dos meios de produção nas mãos de um pequeno número de magnatas do capital, mas sim ao progressivo aumento do número total de capitalistas.

Uma das causas explicativas apresentadas por Bernstein para tal fenômeno consiste na proliferação de sociedades por ações em inúmeros campos da economia. Cabe ressaltar que embora fossem vistas como potencialmente benéficas para a economia, em virtude da ampliação da distribuição do "produto social excedente" para maior número de indivíduos, para o autor a expansão das sociedades por ações, no entanto, seria igualmente responsável pelo surgimento de cada vez mais "capitalistas-parasitas", ou seja, proprietários que não possuem qualquer relação funcional com o processo produtivo - do qual participam apenas como acionistas - partilhando de seus lucros, mas não da responsabilidade ${ }^{569}$.

Outro fator a ser considerado seria o aumento significativo da quantidade de grandes e médias empresas e sua convivência com as pequenas empresas e manufaturas. Estas confirmariam a sua sobrevivência diante das grandes não somente em função de sua distribuição geográfica, mas em função do processo de diversificação e complementação dos ramos produtivos ${ }^{570}$. No comércio e na agricultura a integração entre o pequeno, o médio e o grande negócio seria mais forte do que na indústria, de modo que se asseguraria, igualmente, a coexistência de grandes, médios e pequenos proprietários - ainda que a significação social deste último grupo em termos de participação no volume total da produção tivesse sofrido uma importante diminuição ${ }^{571}$.

\footnotetext{
${ }^{568}$ Ver tabelas incluídas no item "Anexo", ao final da dissertação.

569 BERNSTEIN. "Las premisas del socialismo y las tareas de la socialdemocracia". In: Las Premisas del socialismo y las tareas de la socialdemocracia. Problemas del socialismo. El revisionismo en la socialdemocracia. México: Siglo Veintiuno, 1982, p.309. Publicado em 1899.

${ }^{570}$ Cf. BERNSTEIN. "La situación actual del desarrollo industrial en Alemania". In: Las Premisas del socialismo y las tareas de la socialdemocracia. Problemas del socialismo. El revisionismo en la socialdemocracia. México: Siglo Veintiuno, 1982, p.27. Artigo integrante da coleção "Problemas do Socialismo", publicado em 1896-1897 pela Neue Zeit, vol.XV, I.

571 BERNSTEIN. "El nuevo desarrollo de las relaciones agrarias en Inglaterra". In: Las Premisas del socialismo y las tareas de la socialdemocracia. Problemas del socialismo. El revisionismo en la socialdemocracia. México: Siglo Veintiuno, 1982, p.64. Artigo integrante da coleção "Problemas do Socialismo", publicado em 1896-1897 pela Neue Zeit, vol.XV, I.
} 
Ao lado da diversificação dos ramos produtivos e da ampliação dos mercados, Bernstein acrescenta ainda outras causas econômicas de fundamental relevância para a estabilidade econômica e o progresso social, como, por exemplo, o desenvolvimento e a difusão do sistema creditício moderno, a formação de cartéis e trusts ${ }^{572}$, a ampliação e aceleração do comércio, a rapidez da propagação das informações sobre as condições do mercado (devido ao aperfeiçoamento dos mecanismos de comunicação - como o serviço postal, telegráfico e de transporte de pessoas e bens) e o desenvolvimento da estatística comercial.

Deste modo, a seu ver, o domínio das indústrias e de seus mercados seria demasiadamente vasto e organizado para que pudesse ser golpeado por uma única crise de alcance geral. Da mesma forma, a probabilidade de ocorrência de crises simultâneas de igual gravidade em todos os ramos produtivos seria praticamente nula, dependendo, para tanto, de acontecimentos extraordinários, aptos a espantar por igual ao mundo dos negócios e a paralisar o crédito em todo o conjunto dos países ${ }^{573}$.

Tendo em vista estas mudanças sócio-econômicas geradas no interior do modo de produção capitalista, Bernstein defende que a caracterização sumária da tendência resultante do processo de acumulação do capital apresentada por Marx em "O Capital" não se realizaria completamente na prática, pois poderia ser "abafada", e, sob certas circunstâncias, até "aniquilada"574.

A capacidade de adaptação, estabilização e auto-regulação desenvolvidas pelo progresso técnico e econômico do capitalismo seria prova suficiente, segundo Bernstein, da refutação da teoria do colapso e da desqualificação de quaisquer pretensões utópicorevolucionárias baseadas na tomada violenta do poder político. Assim, a "era das revoluções políticas" estaria condenada, na medida em que os períodos de crise econômica mostrar-seiam menos intensos e ocorreriam em intervalos de tempo cada vez mais esparsos. Os gráficos

\footnotetext{
${ }^{572}$ As associações formadas por capitalistas infligiriam uma alta artificial dos preços, de modo que conseguiriam evitar a queda vertiginosa dos preços de seu setor em tempos depressão.

573 BERNSTEIN. "La lucha de la socialdemocracia y la revolución de la sociedad". In: Las Premisas del socialismo y las tareas de la socialdemocracia. Problemas del socialismo. El revisionismo en la socialdemocracia. México: Siglo Veintiuno, 1982, p.72. Artigo da Die Neue Zeit, vol. XVI, I, em 1897/1898.

574 BERNSTEIN. Socialismo evolucionário. Rio de Janeiro: Zahar, 1997, p. 150. Esta publicação apresenta a tradução de "Os pressupostos do socialismo e as tarefas da social-democracia" para o português, com introdução de Antonio Paim.
} 
apresentados abaixo representariam, de acordo com Bernstein, as duas concepções a respeito das crises econômicas na sociedade capitalista, vigentes na social-democracia ${ }^{575}$.

Fig.1

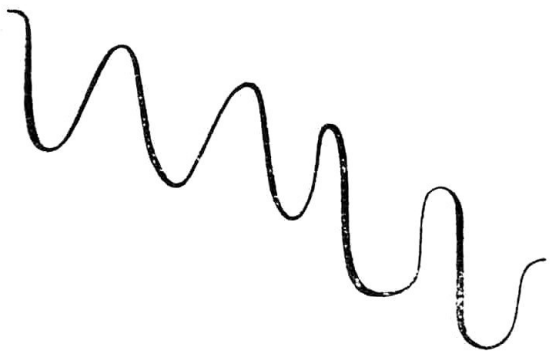

Fig.2

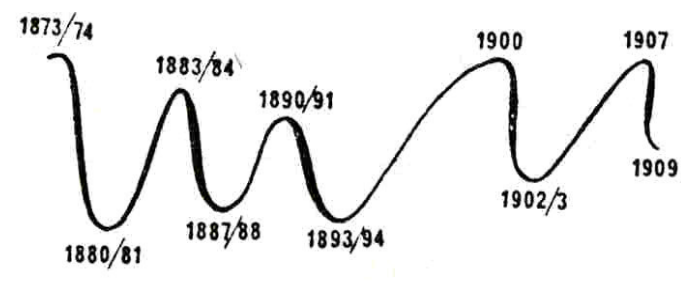

A primeira figura estaria em conformidade com a perspectiva do marxismo ortodoxo, qual seja, a expectativa de incidência de ciclos econômicos alternados de prosperidade e depressão em intervalos de tempo cada vez mais curtos, percorrendo uma trajetória descendente em direção a patamares sócio-econômicos mais graves ${ }^{576}$. Já a segunda figura representaria o ponto de vista revisionista, ao indicar a progressiva mitigação das crises, enfatizando o prolongamento dos períodos de crescimento econômico, interrompidos unicamente por crises de efeitos limitados a certos setores produtivos, corroborando a idéia de uma trajetória ascendente da sociedade capitalista, rumo ao progresso econômico e social.

Tal progresso social e econômico cogitado por Bernstein não se processaria à margem da classe trabalhadora. $\mathrm{O}$ abrandamento das crises, a crescente produtividade da economia, a rentabilidade do trabalho social global e a abertura de novos ramos produtivos em função do avanço tecnológico levariam à gradual melhora das condições de vida dos trabalhadores. Assim, embora as distâncias sociais entre as classes mais abastadas e as mais pobres da sociedade aumentassem consideravelmente, isto não representaria a piora da situação do proletariado. Ao revés, não apenas a classe proletária seria beneficiada pelo célere aumento da riqueza $\operatorname{social}^{577}$ - o que desmentiria a tese marxiana da pauperização - como também desfrutaria de uma maior possibilidade de ascensão social. A seguir apresentamos a

\footnotetext{
575 BERNSTEIN. "El revisionismo en la socialdemocracia". In: Las Premisas del socialismo y las tareas de la socialdemocracia. Problemas del socialismo. El revisionismo en la socialdemocracia. México: Siglo Veintiuno, 1982, p. 310-311. Gráficos extraídos do informe apresentado por Bernstein à Associação dos Trabalhadores de Amsterdã em 4 de abril de 1909, intitulado "O Revisionismo na Social-Democracia".

${ }^{576}$ Observe-se que Engels, no Prefácio à primeira edição de "Miséria da filosofia”, de Karl Marx, adverte que "o período de prosperidade geral que precede as crises nem sempre aparecerá; e, na sua falta, uma estagnação crônica, com ligeiras flutuações, tornar-se-ia o estado normal da indústria moderna" (Marx, 1976, p.16).

${ }^{577}$ Ver tabela 6, no item “Anexo", ao final da dissertação.
} 
representação gráfica ${ }^{578}$ da "nova tendência da divisão social" conjeturada por Bernstein, em contraste com a visão tradicional da social-democracia:

Fig.3

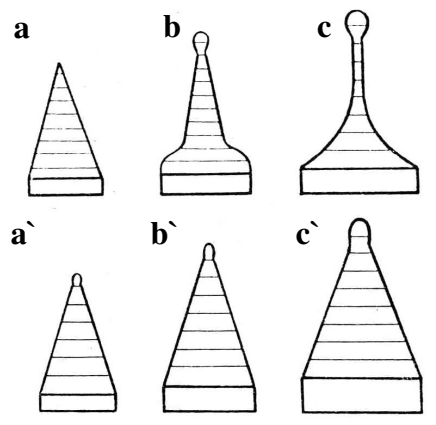

A primeira seqüência de imagens $(a, b, c)$ representa a tese social-democrata condizente com a doutrina marxista que considera os efeitos da concentração de capital e da pauperização na transformação da estratificação social, redundando na progressiva polarização das classes sociais e no acirramento da luta de classes. A segunda série de figuras (a', b', c') expressa a concepção bernsteiniana da evolução da divisão social no âmbito da sociedade capitalista avançada. Esta ressalta o fortalecimento das classes capitalistas mais altas sem, contudo, menosprezar o crescimento do restante das camadas sociais intermediárias, compostas tanto por profissionais autônomos, funcionários do Estado e trabalhadores qualificados quanto por médios e pequenos proprietários.

Segundo Bernstein, a incessante diferenciação e evolução do complexo organismo social provariam que a luta de classes não poderia ser confinada a um simples esquema, isto é, não poderia ser explicada pela "fácil dicotomização social" 579 .

Até um certo ponto estas dicotomias [burguesia e proletariado, capitalistas e trabalhadores assalariados, ricos e pobres] são úteis, mas a complexidade da sociedade contemporânea mostra que estas polarizações simplistas refletem insuficientemente a exigência de uma exatidão científica. Formações partidárias políticas e sociais atuais que não mais se encaixam nas velhas categorias dicotômicas provam que a questão da classe não pode ser vista meramente como uma tergiversação teórica. ${ }^{580}$

\footnotetext{
${ }^{578}$ BERNSTEIN. "El revisionismo en la socialdemocracia”. In: Las Premisas del socialismo y las tareas de la socialdemocracia. Problemas del socialismo. El revisionismo en la socialdemocracia. México: Siglo Veintiuno, 1982, p. 309. Representação gráfica extraída do informe apresentado por Bernstein à Associação dos Trabalhadores de Amsterdã em 4 de abril de 1909, intitulado "O Revisionismo na Social-Democracia".

579 BERNSTEIN. "Class and class struggle". In: Selected writings of Eduard Bernstein: 1900 - 1921. New Jersey: Humanities Press, 1996, p.128. Artigo publicado pela Sozialistische Monatshefte, em 1905.

${ }^{580}$ Ibid, p. 124.
} 
Por conseguinte, do ponto de vista bernsteiniano, conforme a sociedade evoluiria, aumentaria em complexidade, tornando inválida e errônea a projeção da polarização das classes sociais. Este fato tornaria os conceitos de "classe" e "luta de classes" frágeis e fluidos, posto que já não corresponderiam a fenômenos empíricos simples e delimitados, tal como na teorização marxista. Neste sentido, o progressivo processo de aumento e diversificação das camadas sociais médias, somado ao interesse da própria classe trabalhadora no progresso econômico e social - já que o proletariado como um todo se beneficiaria do incremento da produção e da acumulação de capital - redundariam na atenuação dos antagonismos de classe.

Bernstein argumenta então que a luta de classes tenderia a assumir naturalmente um caráter "mais civilizado" nas sociedades industriais desenvolvidas. Justamente este "refinamento da luta de classes em uma nova forma política e econômica" ${ }^{581}$ asseguraria a realização do socialismo, pois, desta maneira, a social-democracia poderia transformar-se no "partido do povo", e os trabalhadores tornar-se-iam o fator social decisivo em torno do qual outros grupos sociais iriam se agrupar ${ }^{582}$.

Bernstein, no entanto, não contradiz a análise de Marx que atribui aos fatores que causam o desenvolvimento da força expansiva do capital a causa da ampliação da força de trabalho disponível. Todavia, mesmo admitindo que o crescimento da acumulação capitalista seria acompanhado pelo aumento relativo do exército industrial de reserva rejeita a teoria da pauperização.

Ao contrário do entendimento marxiano de que "todos os meios que perseguem o desenvolvimento da produção se convertem em meios de dominação e de exploração a serviço do proprietário", e de que "à medida que se opera a acumulação do capital, a situação do operário - quer ele ganhe pouco ou muito - só pode piorar" ${ }^{\text {"583 }}$, Bernstein desvincula o processo de acumulação de riquezas nas mãos dos proprietários da crescente "acumulação de misérias, de sofrimento, de escravidão, ignorância, embrutecimento e degradação moral" do proletariado $^{584}$.

Para Bernstein, a regulação da economia e uma legislação social protetora, combinadas com períodos de prosperidade e avanço produtivo, conseguiriam manter e até

\footnotetext{
${ }^{581}$ BERNSTEIN. "What is socialism?". In: Selected writings of Eduard Bernstein: 1900 - 1921. New Jersey: Humanities Press, 1996, p.158. Artigo publicado em 1918.

582 BERNSTEIN. "Guiding principles for the theoretical portion of a social democratic party program." In: Selected writings of Eduard Bernstein: 1900 - 1921. New Jersey: Humanities Press, 1996, p.82. Artigo publicado em 1909.

${ }_{583}$ Marx, 1969, p. 170 .

${ }^{584}$ Ibid.
} 
incrementar o nível de vida da classe trabalhadora, uma vez que forneceriam condições para a progressiva socialização da riqueza produzida.

Este deslocamento da noção de exploração do âmbito da produção para o âmbito da distribuição leva Bernstein a concentrar mais uma vez seus esforços revisionistas para empreender a crítica da teoria do valor marxiana. Do ponto de vista bernsteiniano, a teoria do valor apresentada por Marx estaria fundada em dois princípios incomensuráveis, a saber, o tempo de trabalho socialmente necessário à produção e a utilidade social:

Eu estou mais do que nunca convencido da natureza abstrata das investigações de Marx. Embora originalmente fundamentada, não pode ser mantida se lidamos com uma análise do valor como fator de determinação dos preços. ${ }^{585}$

Com efeito, para investigar a lei da mais-valia, Marx teria abstraído a questão da utilidade (demanda), assumindo para determinados períodos de tempo uma equalização entre oferta e demanda. Para superar tal "lacuna" na teoria de Marx, Bernstein defende a complementaridade entre a teoria do valor-trabalho e a teoria da utilidade marginal da escola anglo-austríaca (de Jevons e Böhm-Bawerk) ${ }^{586}$, que introduzem uma teoria subjetivista do valor baseada no interesse.

Procedendo desta forma, Bernstein acaba por endossar a concepção de Werner Sombart, para quem o conceito de valor em Marx seria uma contribuição puramente teórica que não corresponderia a nenhuma formação social histórica ${ }^{587}$. Segundo esta perspectiva, a teoria do valor - retomada no terceiro livro ${ }^{588}$ de "O Capital", publicado em 1894 - baseada

\footnotetext{
${ }^{585}$ BERNSTEIN. "La significación política y social del espacio y del número". In: Las Premisas del socialismo y las tareas de la socialdemocracia. Problemas del socialismo. El revisionismo en la socialdemocracia. México: Siglo Veintiuno, 1982, p.40. Artigo publicado pela Die Neue Zeit, vol XV, II, em 1896/1897.

${ }^{586}$ Eugen von Böhm-Bawerk, em "Zun Abschluss des Marxschen Systems", de 1896, defendeu que nenhuma prova dedutiva ou empírica da teoria do valor-trabalho pode ser sustentada com sucesso (Steger, 1997). O político, economista e jurista Böhm-Bawerk (1851-1914) foi aluno do marginalista Carl Menger, tendo desenvolvido sua "teoria positiva do capital" ("Positive Theorie des Kapitales") em 1889. Neste o autor refuta a teoria da exploração, difundida pelos socialistas, de acordo com a qual o trabalhador, no sistema capitalista, não percebe o valor pleno do produto de seu trabalho. Segundo o economista liberal, paga-se aos trabalhadores a totalidade do valor por eles empregado à produção na forma de prestações, imediatamente após a realização de cada serviço (Böhn-Bawerk, 1986, p.99-103).

${ }^{587}$ Segundo Engels, a formulação de Sombart, em "Archiv für soziale Gesetzgebung" - revista política editada por Heinrich Braun - sobre a teoria do valor "não esgota de maneira alguma a significação completa da lei do valor" (ENGELS, F. "Suplemento ao Livro Terceiro de "O Capital”". In: O Capital. São Paulo: Nova Cultural, 1986, p.324).

${ }^{588}$ O terceiro volume do Capital, que trata do processo global da produção capitalista, mais particularmente a sua terceira parte referente à lei tendencial da queda da taxa de lucro, que aponta os fatores atuantes no processo como a elevação do grau da exploração do trabalho, a compressão do salário abaixo de seu valor, o barateamento dos elementos do capital constante, a superpopulação relativa, o comércio exterior e o aumento do capital por ações - suscitou muitas dúvidas em Bernstein, contribuindo para seu afastamento definitivo da teoria econômica marxiana.
} 
no tempo de trabalho socialmente necessário, seria uma construção derivada de categorias especulativas ${ }^{589}$, próprias da filosofia hegeliana. Deste modo, “à medida que um determinado artigo ou uma categoria de artigos é considerado, o valor perde toda e qualquer qualidade concreta e converte-se num conceito puramente abstrato" ${ }^{, 590}$.

Ao considerar o conceito de valor-trabalho exclusivamente como uma formulação especulativa ou hipótese científica, a mais-valia torna-se, igualmente, apenas uma "fórmula apoiada sobre uma hipótese" ${ }^{\circledR 591}$. Assim como a teoria do valor foi descartada, a teoria da maisvalia também seria reduzida a uma mera ilustração, uma imagem metafísica que não corresponderia à realidade social. A mais-valia seria "enganadora" sobretudo porque seria apresentada como a medida da real exploração do trabalhador pelo capitalista, sendo caracterizada a taxa de mais-valia como taxa de exploração.

Segundo Bernstein, na realidade, "a teoria do valor empresta uma norma tão insignificante à justiça ou injustiça da partilha do produto do trabalho quão diminuta é a influência da teoria atômica na beleza ou fealdade de uma obra de escultura" ${ }^{\text {"592 }}$. Isto significaria que uma base científica para o socialismo não poderia desconsiderar imperativos éticos e se apoiar exclusivamente no fato de o trabalhador assalariado não receber o valor integral do produto do seu trabalho.

Para contornar este problema Bernstein propõe que a concepção de exploração não esteja baseada unicamente em termos econômicos, devendo a teoria do valor enfatizar seus componentes morais, escorados em princípios transcendentais de igualdade e justiça ${ }^{593}$. Desta forma, Bernstein resgata a concepção idealista de justiça tal como esta se apresentara nas obras de Proudhon ${ }^{594}$ - cuja crítica à sociedade capitalista valia-se de preceitos extraídos de

\footnotetext{
${ }^{589}$ Contrariamente às teses que concebem a teoria do valor como uma categoria abstrata, uma mera especulação metafísica ou hipótese dissociada da realidade, a entendemos como instrumento teórico capaz de dar conta da complexidade e ambigüidade do modo de produção capitalista. Seguindo Oskar Negt, trata-se da "quintessência e o núcleo das categorias da realidade, das leis que estruturam a realidade social e asseguram a conexão intrínseca no real", ou seja, "uma lei estrutural da história, na medida em que esta conhece a produção de mercadorias" (Hobsbawm, 1989, p.148).

${ }^{590}$ BERNSTEIN. Socialismo evolucionário. Rio de Janeiro: Zahar, 1997, p.48.

${ }^{591}$ Ibid.

592 Ibid., p.53.

${ }^{593}$ Steger, 1997, p.128.

${ }^{594}$ Bernstein deixa claro no prefácio à edição francesa de "Os pressupostos do socialismo e as tarefas da socialdemocracia" (publicado em 1900, na Sozialistische Monatshefte, sob o título "Aos meus críticos socialistas") sua intenção de resgatar e revalidar idéias da tradição socialista já rechaçadas por Marx e Engels: "Não fui eu, mas as atualidades da vida real que ressuscitaram o autor de Capacités Politique de la Classe Ouvrière. Isto não significa que a crítica de Marx a Proudhon está inteiramente fora de questão, mas simplesmente que não mais se aplica a tudo que Proudhon afirmou. O mesmo vale para as contribuições de outros socialistas geralmente vistos
} 
uma "justiça eterna" derivada da própria "essência da humanidade",595, uma vez que a justiça nada mais seria do que o "instinto de sociedade que nos governa"596.

Aderindo a tal fraseologia idealista, típica da pequeno-burguesia ${ }^{597}$, Bernstein passa a sustentar que a mais-valia dispensaria uma prova dedutiva por ser um fato empírico demonstrável pela experiência, isto é, pela injusta distribuição da riqueza social. O revisionismo bernsteiniano, portanto, pretende retirar da análise científica marxiana os alicerces fundamentais que sustentam a crítica ao modo de produção capitalista: o valortrabalho, que desvela o caráter social do trabalho abstrato, e a mais-valia, prova objetiva do caráter antagônico intrínseco ao processo produtivo operado na sociedade capitalista. Utilizando-se deste artifício duvidoso Bernstein consegue fazer esmaecer a oposição fundamental entre capitalistas e assalariados, de modo que ambas as classes passam a partilhar do mesmo interesse comum, qual seja, o aumento da produtividade e o progresso da economia capitalista.

O abrandamento do antagonismo de classe, por sua vez, levaria o proletariado a unir forças com grupos sociais progressistas e, conseqüientemente, ampliar paulatinamente seu poder social de modo a viabilizar a construção do socialismo. Por este motivo, o autor propõe uma nova palavra de ordem à social-democracia que implicaria na reformulação de toda sua postura política: "a linguagem do reformismo é a linguagem da moderação" 598 . Este apelo à moderação não será demovido mesmo em face da maior e mais expressiva conquista realizada pela classe trabalhadora até o presente, consubstanciada na Revolução Russa de 1917, movimento repudiado tanto pela ala direitista quanto centrista do Partido Social-Democrata Alemão.

como antiquados e que foram em grande parte esquecidos. O grande movimento socialista contemporâneo ressuscitou-os ao realizar parcialmente suas idéias" (Bernstein, 1996, p. 42).

595 MARX \& ENGELS. "Contribuição ao problema da habitação". In: Obras escolhidas. São Paulo: AlfaOmega, v.2, 1980b, p.170. Escrito por Engels em 1872.

${ }^{596}$ PROUDHON. O que é a propriedade?. Lisboa: Estampa, 1997, p. 199. Para Proudhon, portanto, "praticar a justiça é obedecer ao instinto social; fazer um ato de justiça é fazer um ato de sociedade" (Proudhon, 1997, p.197).

597 Tal como Proudhon, Bernstein estaria "ofuscado pela magnificência da grande burguesia" resguardando ainda certa "simpatia pelos sofrimentos do povo", algo que Marx considera típico da pequena-burguesia: "Ele (o pequeno-burguês) é burguês e povo ao mesmo tempo. Em seu for íntimo, orgulha-se de ser imparcial, de ter encontrado o equilíbrio justo, e tem a pretensão de ser algo mais do que o áureo meio-termo". Cf. Carta de Marx a P.V. Annenkow, de 28 de dezembro de 1846 (Marx, Engels, 1983, p.466).

598 BERNSTEIN. "Guiding principles for the theoretical portion of a social democratic party program." In: Selected writings of Eduard Bernstein: 1900 - 1921. New Jersey: Humanities Press, 1996, p.81. Artigo publicado em 1909. 
Contudo, mesmo ao sustentar que a política da classe trabalhadora não estaria necessariamente em oposição absoluta com os interesses de outras classes, defendendo então uma política de abertura a coalizões com outras classes sociais, Bernstein não coloca em dúvida a "missão histórica" do proletariado e o papel de liderança a ser exercido pelo Partido Social-Democrata no que diz respeito à concretização das transformações sociais no sentido do socialismo. Neste aspecto, segundo Bernstein, a social-democracia preservaria seu caráter "revolucionário":

Temos que ter em mente que um partido proletário - seja ele organizado em torno de sindicatos, como o Partido Trabalhista Inglês, ou organizado politicamente, como o Partido SocialDemocrata Alemão - deve permanecer revolucionário no sentido de que deve endossar o amplo progresso nas dimensões econômica, social, política e ética da sociedade [grifo nosso]. . $^{99}$

Com efeito, a implementação do socialismo, processo este tido como já iniciado, seria conseqüência da crescente influência do movimento operário e de seu desenvolvimento econômico, político e ético. Não sobreviria de uma única e decisiva batalha política, mas do resultado de uma série de vitórias políticas e econômicas do proletariado em várias dimensões da vida social. Bernstein, portanto, não enxerga a sociedade socialista brotando do "inexorável caos", mas sim emergindo lentamente de uma combinação de conquistas de uma classe trabalhadora criativa e de um processo de democratização efetivado em todos os níveis da sociedade:

$\mathrm{O}$ amadurecimento do proletariado moderno dispensa utopias; ele pode levar adiante a luta socialista sem um impreciso "objetivo final". (...) a sua crescente importância para a sociedade moderna e a missão histórica de sua classe se expressa na busca de verdadeiro progresso no conhecimento, na tecnologia e na economia. ${ }^{600}$

Tanto a pressão exercida pelo movimento operário quanto a influência das instituições democráticas seriam, a seu ver, responsáveis pela mobilização social contra as tendências exploradoras do capital, concentração esta que estenderia cada vez mais o campo de suas operações $^{601}$. Como prova deste fato, Bernstein apresenta a ampliação das leis fabris, a

\footnotetext{
599 BERNSTEIN. "What is socialism?". In: Selected writings of Eduard Bernstein: 1900 - 1921. New Jersey: Humanities Press, 1996, p.152. Artigo publicado em 1918.

${ }^{600}$ BERNSTEIN. "Revisionism in social democracy". In: Selected writings of Eduard Bernstein: 1900 - 1921. New Jersey: Humanities Press, 1996, p.79. Artigo publicado em 1909.

${ }^{601}$ BERNSTEIN. "The socialist conception of democracy". In: Selected writings of Eduard Bernstein: 1900 1921. New Jersey: Humanities Press, 1996, p. 145. Artigo publicado pela Die Neue Zeit em 1916.
} 
democratização da administração municipal e a expansão de seu campo de atuação, a emancipação das instituições sindicais e corporativas de toda trava legal e a tomada em consideração das organizações operárias para todos os trabalhos executados pela administração pública.

Assim, a democratização das instituições políticas modernas tornaria não somente improvável, mas igualmente desnecessária a ocorrência de grandes "catástrofes políticas", além de propiciar um certo comodismo e indisposição psicológica, entre os membros da social-democracia, para uma tomada violenta do Estado ${ }^{602}$.

A democracia, portanto, é apresentada simultaneamente como o meio e o fim do socialismo. Não apenas seria a sua via de concretização, mas também a sua mais pura essência, na medida em que o socialismo nada mais seria do que a concretização dos ideais democráticos herdados do liberalismo político ${ }^{603}$. Para Bernstein, portanto, a incorporação das exigências libertárias advindas do liberalismo burguês - sua ênfase nos direitos humanos, na individualidade e na igualdade perante a lei - seria a base para a implementação da democracia, não somente dentro do próprio partido, mas também na sociedade.

A importância atribuída por Bernstein às instituições democráticas burguesas para a conversão gradual da sociedade capitalista em uma sociedade socialista culmina na necessidade de uma redefinição do caráter do Estado moderno. Este não mais seria visto exclusivamente como o "balcão de negócios da burguesia", mas como um órgão administrativo central fundado em princípios racionais, apto a ser colocado a serviço do interesse geral. A reorganização do Estado pela social-democracia, seja através da participação no Parlamento e na administração ou da simples pressão popular, tornaria possível a utilização de seu aparato como propulsor da reforma social.

Todavia, para que o Estado desempenhasse a função de "guardião nacional dos interesses comuns do povo" seria indispensável que fossem asseguradas as liberdades políticas básicas para todos os cidadãos, isto é, que fossem abolidos privilégios de classe através da implantação do sufrágio universal e da liberdade de associação e imprensa. Desta maneira, aonde a maioria da população dos centros urbanos fosse representada pela moderna

\footnotetext{
602 Ibid.

${ }^{603}$ Cf. BERNSTEIN. "Las Premisas del socialismo y las tareas de la socialdemocracia.". In: Las Premisas del socialismo y las tareas de la socialdemocracia. Problemas del socialismo. El revisionismo en la socialdemocracia. México: Siglo Veintiuno, 1982, p. 218-223. Publicado em 1899.
} 
classe operária, o sufrágio universal representaria a submissão gradual do poder do Estado à vontade do proletariado ${ }^{604}$.

Conseqüentemente, a conquista do sufrágio universal é vista por Bernstein como "a verdadeira revolução social", enquanto que o "genuíno parlamentarismo", baseado no sufrágio universal, representaria na sociedade moderna industrial "a ferramenta mais efetiva para a implementação de profundas e graduais reformas, sem derramamento de sangue" ${ }^{\mathrm{605}}$ :

O sufrágio universal e a ação parlamentar devem ser vistas como o ápice, a forma mais completa da luta de classes - uma revolução orgânica e permanente que é lutada dentro dos parâmetros legais, refletindo o nível de desenvolvimento cultural que corresponde à moderna civilização. ${ }^{606}$

Devido à importância deste instrumento, Bernstein endossa a utilização da greve política de massas com vistas à sua aquisição. Contudo, a greve de massas deveria ser vista apenas como uma medida de emergência, não devendo ser utilizada como um "jogo pseudorevolucionário de românticos insurretos", tal como em sua concepção estaria ocorrendo na Rússia em $1905^{607}$. Nesta ocasião, contrapôs-se energicamente ao entusiasmo de Rosa Luxemburg $^{608}$ e dos sindicalistas revolucionários, argumentando que tal instrumento estaria sendo utilizado de modo irracional, desconsiderando-se as condições temporais e espaciais concretas.

Pelo fato de a greve política atingir não apenas o regime político, mas também afetar todo o setor comercial e, indiretamente, a própria classe trabalhadora, o autor impõe uma série de restrições à sua utilização. Em sua concepção, os únicos casos em que a greve possui condições de sair vitoriosa ocorrem quando a greve é apoiada por toda a sociedade civil, ou se detiver poder suficiente para se impor tanto às partes hostis da sociedade civil quanto ao governo.

Nestes termos, a greve política deveria ser exercida simplesmente como um forte apelo à consciência pública, no intuito de despertar um adormecido senso de justiça nas demais classes sociais. Neste caso acima de tudo a greve representaria uma "espada

\footnotetext{
${ }^{604}$ BERNSTEIN. "Idealism, theory of struggle and science". In: Selected writings of Eduard Bernstein: 1900 1921. New Jersey: Humanities Press, 1996, p.109. Artigo publicado pela Sozialistische Monatshefte, em 1901.

${ }^{605}$ Cf. BERNSTEIN. "Political mass strike and romanticizing revolution". In: Selected writings of Eduard Bernstein: 1900 - 1921. New Jersey: Humanities Press, 1996, p.138. Artigo publicado pela Sozialistische Monatshefte em 1906.

${ }^{606}$ Ibid., p. 139.

${ }^{607}$ Ibid., p. 136

${ }^{608}$ Ver LUXEMBURG, Rosa. Grève de masse, parti et syndicats. Paris: François Maspero, 1969.
} 
econômica empunhada por propósitos éticos" ${ }^{609}$, a profunda expressão da luta por justiça que, usada na hora certa, transformar-se-ia em uma poderosa conclamação a que outras classes se engajassem na luta do proletariado.

Uma vez obtido o sufrágio universal, no entanto, outros meios de luta obteriam maior destaque e credibilidade. Além da atuação legislativa no âmbito parlamentar, formas de organização e associação de trabalhadores - como sindicatos ${ }^{610}$ e cooperativas de consumo ${ }^{611}$ - tornar-se-iam fatores cruciais na luta emancipatória, por despertarem sentimentos de solidariedade e responsabilidade. Estas instituições contribuiriam para organizar e disciplinar politicamente a classe trabalhadora, preparando-a para a democracia. Isto se deve ao fato de que, como todos os corpos democráticos, os sindicatos e as cooperativas seriam órgãos bem estruturados que censurariam severamente as infrações ao dever e que, ao mesmo tempo, saberiam estimular a responsabilidade de seus membros e cuidar para que esta fosse cumprida $^{612}$. Assim, gradualmente a classe desenvolveria uma moral e uma consciência jurídica que a habilitariam a participar da administração do Estado e da economia ${ }^{613}$.

Do ponto de vista revisionista, portanto, as tarefas incumbidas à social-democracia consistiriam no estímulo à formação de cooperativas de consumo e sindicatos, além do total apoio à luta parlamentar. Desta forma, progressivamente o proletariado ocuparia espaços políticos, econômicos e morais na sociedade, influindo nos rumos do desenvolvimento social. Logo que uma nação atingisse uma posição em que os direitos da minoria proprietária cessassem de ser um sério obstáculo ao progresso social, onde as tarefas negativas da ação

\footnotetext{
${ }^{609}$ BERNSTEIN. "Political mass strike and romanticizing revolution". In: Selected writings of Eduard Bernstein: 1900 - 1921. New Jersey: Humanities Press, 1996, p.138. Artigo publicado pela Sozialistische Monatshefte em 1906, p.138.

${ }^{610}$ Não obstante seu apreço pelos sindicatos, Bernstein admite que os sindicatos podem revestir-se, por vezes, de um caráter egoísta ou mesmo reacionário, seja por defenderem interesses particulares, não extensivos a toda a classe trabalhadora, seja por realizarem pressões com vistas a obstaculizar o progresso das forças produtivas (Bernstein, 1982, p. 51).

${ }^{611}$ Segundo Bernstein, enquanto as cooperativas de produção teriam experimentado um significativo fracasso econômico, em função das dificuldades administrativas encontradas que levaram à sua oligarquização mostrando-se inadequadas à grande produção moderna -, a cooperativa de consumo ter-se-ia mostrado muito mais eficiente e em consonância com os interesses do proletariado. Estas representariam uma força econômica real, um organismo com grande capacidade de direção e desenvolvimento, cujo interesse não estaria em oposição ao interesse coletivo, por resultar na baixa geral dos preços das mercadorias (Bernstein, 1982, p.195).

${ }^{612}$ BERNSTEIN. "La significación política y social del espacio y del número". In: Las Premisas del socialismo y las tareas de la socialdemocracia. Problemas del socialismo. El revisionismo en la socialdemocracia. México: Siglo Veintiuno, 1982, p.51.

${ }^{613}$ BERNSTEIN. "El factor realista y el factor ideológico en el socialismo". In: Las Premisas del socialismo y las tareas de la socialdemocracia. Problemas del socialismo. El revisionismo en la socialdemocracia. México: Siglo Veintiuno, 1982, p.79. Artigo publicado pela Die Neue Zeit, vol. XVI, II, em 1897/1898.
} 
política fossem menos prementes do que as positivas, então "o apelo à revolução pela força" converter-se-ia numa "frase sem sentido" 614 .

\subsection{2- A evolução social em direção ao socialismo}

Sob o prisma bernsteiniano, apesar de mais vagarosa do que o caminho revolucionário, no tocante à remoção dos obstáculos que uma pequena minoria colocaria no caminho do progresso social, a evolução social por via de reformas legislativas seria mais sólida, permanente e melhor adaptada ao trabalho político-social positivo. Enquanto no esquema revolucionário, "os preconceitos e os horizontes limitados da grande massa do povo surgem como grande obstáculo ao progresso social", na legislação, "o intelecto prevalece sobre a emoção",615.

A ação parlamentar - percebida como ética e racional - levada a efeito pela "aristocracia" do partido seria, portanto, a condutora por excelência do processo evolutivo rumo ao socialismo, orientando e restringindo os impulsos revolucionários das massas nãoeducadas. Como consequiência, o processo de transformação histórica passa a ser concebido como resultado dos desígnios de uma elite intelectual atuante na esfera governamental. Evidentemente, tal deslocamento do sujeito da ação histórica transformadora reflete o grau de distanciamento de Bernstein em relação à teoria marxiana, cuja assertiva principal consiste em afirmar que a chave para a emancipação do proletariado reside em suas própria organização. Ao mesmo tempo, mostra a sua sintonia com uma vertente liberal-democrática que se encontrou fortalecida no início do século XX, na medida em que ressalta a iniciativa de traçar estratégias e programas de planejamento econômico e social, no interior da sociedade capitalista, com vistas à remodelação da ordem social.

Seguindo o raciocínio do autor, o SPD deveria assumir seu caráter anti-revolucionário e declarar-se um partido reformista, concentrando-se na sua atividade prática imediata, dirigida à criação de circunstâncias e condições que tornem possível e garantam uma transição lenta, pacífica e sem sobressaltos da moderna ordem social à outra mais evoluída ${ }^{616}$. Neste sentido, Bernstein afirma que o movimento (a série de processos), é tudo, ao passo que a meta final é irrelevante, utópica.

\footnotetext{
${ }^{614}$ BERNSTEIN. Socialismo evolucionário. Rio de Janeiro: Zahar, 1997, p.156.

${ }^{615}$ Ibid.

${ }^{616}$ Ibid., p. 115.
} 
O lento caminho a ser trilhado em direção ao socialismo ${ }^{617}$ envolveria, assim, a intensificação do processo de democratização do Estado e da administração pública através da expansão da democracia para a área social - como educação, saúde, artes e transporte - e econômica. A democratização da esfera econômica, segundo Bernstein, implicaria no controle racional da economia e na eliminação de todas as formas de produção e expropriação "parasitárias" ${ }^{\text {618 }}$, de modo a subordinar os interesses da minoria privilegiada ao interesse comum.

Como Hobson, Bernstein não subscreve a necessidade de uma completa coletivização da economia, pois, em sua opinião, a socialização não implicaria fundamentalmente na nacionalização ou municipalização de todas as empresas, podendo ser desenvolvida gradualmente através de leis e regulamentos que restrinjam o controle privado. Neste sentido, alega que "uma boa legislação fabril pode conter mais socialismo do que a nacionalização de várias centenas de corporações" pois "leva em consideração os interesses do público e apóia o bem-estar do povo em um grau muito mais elevado do que uma rápida nacionalização",619 .

Embora, a seu ver, o interesse da classe proletária exigisse a transferência de monopólios à propriedade pública e o gerenciamento de fábricas e corporações exclusivamente em benefício de toda a sociedade - expandindo-se, desta forma, o controle social sobre a produção e a distribuição -, a passagem gradual da gestão privada à pública poder-se-ia dar de diversas maneiras:

Como representante do povo, o Estado poderia adquirir partes das empresas privadas, e, enquanto deixa a maioria das companhias nas mãos dos capitalistas, o Estado ativamente se envolveria na prevenção de abusos de preços, de lucros excessivos e do desenvolvimento monopolístico de trustes. Ao assumir maior poder de decisão sobre a produção econômica, o público ganharia mais direitos em face da economia privada. ${ }^{620}$

\footnotetext{
${ }^{617}$ Bernstein considera que "o número de pessoas, (...) o tamanho do espaço territorial que elas ocupam, o crescente número de ramos em que se diferencia a produção e a grande quantidade, a diversidade e a extensão das unidades de produção, tudo isto converte em uma grande improbabilidade a harmonização automática de todos os interesses individuais em um interesse comum, que se confirma unificadamente em toda parte e em todo sentido" (Bernstein, 1982, p.49).

${ }^{618}$ Como Bernstein não é adepto da total coletivização da produção, pode-se concluir que as "empresas parasitárias" a que ele se refere são, fundamentalmente, as sociedades por ações - cujos proprietários desfrutariam de lucros exorbitantes sem nenhuma contrapartida em termos de responsabilidade e gerenciamento - e empresas que viveriam da especulação financeira.

${ }^{619}$ BERNSTEIN. “What is Socialism?”. In: Selected writings of Eduard Bernstein: 1900 - 1921. New Jersey: Humanities Press, 1996, p.156. Artigo publicado em 1918.

${ }^{620}$ Ibid, p. 155.
} 
Os limites impostos à coletivização justificar-se-iam não somente em virtude do grande número de empresas industriais e agrícolas existentes na Alemanha, mas pela necessidade de se manter um alto nível de produção e eficiência - algo que, segundo Bernstein não conseguiria ser obtido pela gestão de burocratas do Estado ou dos próprios trabalhadores $^{621}$. Além disto, a enorme diferenciação produtiva proporcionada pelas pequenas e médias empresas atenderiam a demandas por produtos heterogêneos ${ }^{622}$. Deste modo, a transformação de corporações privadas em públicas seria um processo que deveria ser cuidadosamente decidido na base da análise de cada caso em particular, averiguando-se quais ramos produtivos e empresas seriam mais adequados à socialização, de maneira a não prejudicar o avanço das forças produtivas e o pleno funcionamento da economia.

Por conseguinte, Bernstein acredita não ser possível nem desejável eliminar o capitalismo "por decreto", uma vez que não se poderia prescindir dele ${ }^{623}$. Entretanto, as empresas que permanecessem em mãos privadas estariam submetidas ao controle público, atendendo prioritariamente aos interesses gerais da população e não à ambição de seus proprietários. ${ }^{624}$

Além da democratização da esfera econômica, a evolução em direção ao socialismo exigiria a descentralização do poder público, seja através do desenvolvimento da autonomia administrativa nas comunas, distritos e províncias (e da ampliação de suas funções), seja por intermédio da difusão de organismos autônomos - como sindicatos, comissões de arbitragem industriais, câmaras de trabalho e cooperativas de consumidores, ou ainda instituições econômicas semi-públicas, como seguradoras para trabalhadores e empresas de natureza econômica mista.

\footnotetext{
${ }^{621}$ Bernstein opõe-se à idéia de transformar trabalhadores em proprietários do dia para a noite. Em sua visão, uma das causas principais da crise vivida na Russa após 1917 teria sido a coletivização de fábricas e a repartição das grandes propriedades agrícolas, pois os trabalhadores, convertidos em proprietários, barrariam os avanços tecnológicos e colocar-se-iam em oposição ao interesse geral. Para Bernstein, estas medidas não seriam efetivamente socialistas (Bernstein, 1996, p.189-190).

${ }^{622}$ Neste ponto, Bernstein adere à defesa da coletivização parcial, tal como esta é apresentada por Hobson: este antevê a conveniência de adaptar-se à idéia de uma comunidade parcialmente coletivista, em que as necessidades gerais, universais dos homens, seriam satisfeitas por "indústrias de rotina" (mecanizadas e coletivistas) - para se atender à demanda por produtos homogêneos ("consumo de massa"). Contudo, as pequenas empresas que atendem a necessidades e gostos especiais e individuais seriam indispensáveis (Cf. Bernstein, 1982, p.17).

${ }^{623}$ BERNSTEIN. "La lucha de la socialdemocracia y la revolucion de la sociedad". In: Las Premisas del socialismo y las tareas de la socialdemocracia. Problemas del socialismo. El revisionismo en la socialdemocracia. México: Siglo Veintiuno, 1982, p.74. Artigo publicado pela Die Neue Zeit, vol. XVI,I, em $1897 / 1898$.

${ }^{624}$ Cf. BERNSTEIN. "Una teoría sobre los domínios y limites del colectivismo". In: Las Premisas del socialismo y las tareas de la socialdemocracia. Problemas del socialismo. El revisionismo en la socialdemocracia. México: Siglo Veintiuno, 1982. Artigo publicado pela Die Neue Zeit, XV, I, e, 1896/1897.
} 
A democracia socialista seria caracterizada, portanto, tanto pela difusão de formas de controle público sobre a produção e a distribuição e pela adoção de um coletivismo limitado, como pela descentralização do poder através da ampliação da democracia política e da participação da sociedade civil. Logo, para Bernstein, a esfera pública deveria funcionar como um fórum aberto à troca de idéias entre cidadãos iguais, não oprimidos por relações econômicas de classe - pressuposto neokantiano que será retomado posteriormente por Jürgen Habermas ${ }^{625}$.

$\mathrm{O}$ estabelecimento de relações equilibradas entre Estado e organismos populares autônomos e democráticos nas municipalidades e províncias permitiria, de acordo com o autor, um incremento do poder popular e a possibilidade de barrar a influência dos interesses particulares e de formas de dominação de classe dentro do governo. Contudo, a importância e necessidade de órgãos intermediários e corpos democráticos auto-administrativos não tornariam o Estado, enquanto ente político, supérfluo. Por mais descentralizada que seja a administração sempre restará tarefas sociais e funções a serem desempenhadas por um órgão central.

Sendo assim, "não se trata, como disse Marx em "A Guerra Civil na França", de desfazer a unidade das nações que se tornaram historicamente grandes, mas de colocá-las sobre uma nova base" ${ }^{, 626}$ :

\begin{abstract}
Não se visualiza uma razão para que no futuro as grandes nações, historicamente construídas, deixem de ser unidades administrativas. Uma fusão total das nações entre si não é esperável nem desejável. As nações podem atender muito bem aos interesses culturais comuns através de convênios e do desenvolvimento do direito internacional, sem por isto renunciarem à sua individualidade. ${ }^{627}$
\end{abstract}

Decerto a ideologia do progresso propugnada pelo autor apresentava traços nacionalistas presentes na cultura alemã dos séculos XIX e XX. Como Norbert Elias assinalou $^{628}$, tal período foi marcado pela mudança na mentalidade dos representantes da intelligentsia das classes médias, cuja identificação com valores e ideais humanistas

\footnotetext{
${ }^{625}$ Cf. HABERMAS, J. Direito e democracia: entre facticidade e validade. Rio de Janeiro: Tempo Brasileiro, 1997.

${ }^{626}$ BERNSTEIN. "La significación política y social del espacio y del numero". In: Las Premisas del socialismo y las tareas de la socialdemocracia. Problemas del socialismo. El revisionismo en la socialdemocracia. México: Siglo Veintiuno, 1982, p. 52. Artigo publicado pela Die Neue zeit, vol. XV, II, e, 1896/1897.

${ }_{627}$ Ibid, p.44.

${ }^{628}$ ELIAS, Norbert. Os alemães: a luta pelo poder e a evolução do habitus nos séculos XIX e XX. Rio de Janeiro: Zahar, 1997, p.119- 158.
} 
orientados para o futuro - e particularmente sua confiança no progresso moral da humanidade - começa a dar lugar à ênfase em valores nacionais, fortalecidos devido à gradual ascensão do Império unificado ao status de grande potência.

Os componentes idealistas da tradição cultural burguesa alemã, que ao longo do século XVIII foram invocados no intuito de afirmar a oposição da burguesia em relação à nobreza, passaram a entrar em declínio à medida que a própria burguesia passava a ocupar posições de destaque no âmbito do Estado. Com efeito,

como símbolo de um desígnio global, como um ideal, o conceito de "progresso" perdeu status e prestígio entre a intelligentsia de classe média dos países onde grupos de classe média se aliaram ou substituíram grupos aristocráticos como os grupos dominantes de seus países. Deixou de ser o auspicioso símbolo de um futuro melhor, iluminado pelo fulgor de fortes sentimentos positivos. No seu lugar, uma imagem idealizada de sua nação passou a ocupar o centro de sua auto-imagem, de suas crenças sociais e de sua escala de valores ${ }^{629}$.

A incorporação de estratos da burguesia à elite política dominante propiciou, portanto, o aburguesamento do código aristocrático, baseado em valores militares de estímulo à coragem, obediência, honra, disciplina, responsabilidade e lealdade. A ampla difusão do código aristocrático e do ethos guerreiro - agora orientados por ideais nacionais - entre os membros da burguesia e da pequena-burguesia repercutiu, por mais paradoxal que possa parecer, no seio da social-democracia, onde setores significativos mostravam-se favoráveis à política colonial e expansionista de Guilherme II.

A posição assumida por Bernstein expressava igualmente tal dualidade. Embora partisse em defesa da conservação das unidades nacionais, posicionava-se simultaneamente a favor da solidariedade internacional entre trabalhadores e da autodeterminação nacional dos países modernos civilizados. Sendo assim, apoiava a idéia de criação de uma Sociedade das Nações, empenhada na solução pacífica dos conflitos internacionais ${ }^{630}$. Todavia, em se tratando de países "mais atrasados" a social-democracia deveria assumir uma postura diferenciada. Segundo Bernstein, nem todo levante de uma nacionalidade ou de uma raça contra seus soberanos deveria suscitar o apoio moral ou ativo da social-democracia, não

\footnotetext{
${ }^{629}$ ELIAS, Norbert. Os alemães: a luta pelo poder e a evolução do habitus nos séculos XIX e XX. Rio de Janeiro: Zahar, 1997, p.129.

${ }^{630}$ BERNSTEIN. Las Premisas del socialismo y las tareas de la socialdemocracia. Problemas del socialismo. El revisionismo en la socialdemocracia. México: Siglo Veintiuno, 1982, p. 234.
} 
obstante toda a justificada simpatia que a social-democracia sentiria pelas lutas de libertação ${ }^{631}$.

A seu ver, a social-democracia deveria opor-se a todo chauvinismo colonial sem cair no extremo oposto de apoiar indistintamente a toda reivindicação por direitos nacionais. Sua posição a respeito da política colonial dependeria, portanto, das instituições e das condições do país que levasse adiante semelhante política, da natureza das colônias projetadas e da forma como o país em questão coloniza e administra suas colônias: ${ }^{632}$

Não quero ver os nativos da África ou de qualquer outro continente explorados ou degolados e tampouco estou de acordo com que lhes imponham modos de vida não apropriados ao seu clima. Foi assinalado, e eu mantenho, o direito da civilização mais elevada sobre a inferior [grifo nosso] - e é incompreensível que um socialista possa negá-lo -, isto não significa que a civilização inferior careça absolutamente de direitos e que os direitos da primeira não imponham obrigações. ${ }^{633}$

Desta maneira, Bernstein acreditava ser possível que os Estados europeus efetivassem medidas colonizadoras que não ferissem os direitos fundamentais dos "selvagens", visando assim uma "regulação humana do problema dos nativos". No seu entender, não apenas não seria necessário que a ocupação das terras tropicais por parte dos europeus prejudicasse a vida dos indígenas, como isto sequer viria ocorrendo até então, posto que os nativos gozariam de ampla proteção ${ }^{634}$.

Com efeito, Bernstein entende que a social-democracia deveria criticar principalmente a forma como são submetidos os "selvagens" e não a dominação em si mesma, uma vez que reconhecia apenas um direito condicionado dos povos nativos sobre os territórios que ocupam. Em sua concepção a civilização superior teria, em última instância, também um direito superior, por representar o "direito da civilização e do progresso contra o espírito retardatário"635. Assim, defendeu que ante as tribos que se adjudicaram o direito de comercializar com escravos ou tribos de ladrões que fizeram do saque a tribos vizinhas de

\footnotetext{
631 BERNSTEIN. "La lucha de la socialdemocracia y la revolución de la sociedad". In: Las Premisas del socialismo y las tareas de la socialdemocracia. Problemas del socialismo. El revisionismo en la socialdemocracia. México: Siglo Veintiuno, 1982, p.55. Artigo publicado pela Die Neue Zeit, vol. XVI, I, em $1897 / 1898$.

${ }^{632}$ Ibid, p. 75-76.

633 Ibid, p. 58.

${ }^{634}$ BERNSTEIN. Las Premisas del socialismo y las tareas de la socialdemocracia. Problemas del socialismo. El revisionismo en la socialdemocracia. México: Siglo Veintiuno, 1982, p. 241.

635 Íbid.
} 
agricultores um oficio permanente, a social-democracia permanecesse indiferente e, dado o caso, as enfrentasse como suas inimigas ${ }^{636}$.

A colonização, portanto, seria benéfica para povos "bárbaros" e "primitivos", tanto econômica quanto culturalmente. A expansão do capitalismo para estas áreas levaria consigo todo o progresso tecnológico e a abundância de mercadorias produzidas nos países centrais, proporcionando maior desenvolvimento social e conforto aos nativos. Além disto, a difusão da cultura moderna - com seus princípios de valorização da personalidade e da vida humana e suas "instituições civilizadoras" - justificaria, por si só, a ocupação destes territórios. Logo, nestes casos, desde que a colonização seja efetuada sem prejuízo dos povos colonizados, a "proteção da dominação européia" conduziria à "difusão da civilização", ao progresso cultural e a um "desenvolvimento geral da humanidade"637. Diz Bernstein:

Por maior que tenha sido a violência, fraude e outras infâmias que acompanharam a expansão da dominação européia nos séculos passados e que atualmente continua em vigor em muitos casos, no entanto, o outro lado da medalha mostra que em geral os selvagens estão melhor agora, sob uma dominação européia ${ }^{638}$.

Apesar de oferecer razões humanistas para a colonização de "povos bárbaros", o autor aponta ainda a importância das colônias para o desenvolvimento dos países capitalistas e o fato de que a ampliação dos mercados e das relações comerciais internacionais seria uma alavanca poderosa para o desenvolvimento social europeu, favorecendo o incremento das forças produtivas e da riqueza destas nações ${ }^{639}$. Destarte, tal como Hobson, Bernstein atribui ao colonialismo um papel relevante na obtenção de mercados externos e na expansão do modo de produção capitalista em âmbito mundial. Longe de representar uma ameaça à socialdemocracia, deveria ser visto como uma aproximação da meta socialista, uma vez que, de acordo com o autor, quanto mais rica for a sociedade, mais fáceis e seguras serão as realizações socialistas ${ }^{640}$.

\footnotetext{
${ }^{636}$ BERNSTEIN. "La lucha de la socialdemocracia y la revolución de la sociedad. In: Las Premisas del socialismo y las tareas de la socialdemocracia. Problemas del socialismo. El revisionismo en la socialdemocracia. México: Siglo Veintiuno, 1982, p. 55. Artigo publicado pela Die Neue Zeit, vol. XVI, I, em 1897/1898.

${ }^{637}$ Ibid, p.61.

${ }^{638}$ Ibid, p.60.

${ }^{639}$ Ibid, p.76.

${ }^{640}$ Ibid, p. 75.
} 
Esta defesa de uma "política colonial positiva", proferida em seu artigo "A luta da social-democracia e a revolução social" ${ }^{\prime 641}$ foi retomada posteriormente nos inúmeros debates travados em congressos e publicações do partido acerca da questão colonial. Contrariando a posição bernsteiniana, o Congresso de Mainz de 1900 aprovou uma resolução condenando a política colonial e militarista do Reich, orientação esta que foi confirmada nos Congressos de Paris (1900) e de Amsterdã (1904) da Internacional.

Embora consagrada em vários documentos oficiais do partido, tal determinação fora cada vez mais questionada pela fração revisionista do SPD. Esta encontrou nos resultados eleitorais de 1907 uma justificativa para a mudança definitiva no discurso da socialdemocracia, de maneira a torná-lo mais palatável aos membros da pequena-burguesia, do campesinato e da burguesia-liberal.

A dissolução do Reichstag, decorrente da primeira "crise do Marrocos" (em 1905) ${ }^{642}$, e o processo eleitoral que a seguiu foram marcados pelo intenso estímulo aos sentimentos nacionalistas, operado tanto pelos canais oficiais do governo como através de organizações não-partidárias conservadoras e liberais - dentre elas destacavam-se a Liga Naval, a Liga PanGermânica, a Liga Imperial contra a Social-Democracia, além de diversos grupos compostos por colonos e militares ${ }^{643}$. A propaganda direcionada contra o Partido Social-Democrata Alemão, e sua caracterização como "traidor" e "antipatriótico", produziu efeitos consideráveis, afastando as classes médias progressistas, seduzidas com as novas promessas da Weltpolitik imperial. Como resultado, a social-democracia sofreu em 1907 uma significativa derrota eleitoral, passando de 81 assentos (conquistados em 1903) para 43 assentos.

Diante do retrocesso nas eleições os representantes do partido no Parlamento passaram a amenizar as suas críticas à política externa do governo e a pressão para a reformulação da política colonial no sudoeste da África. Se antes pronunciavam palavras de ordem contra o

\footnotetext{
${ }^{641}$ BERNSTEIN. "La lucha de la socialdemocracia y la revolución de la sociedad". In: Las Premisas del socialismo y las tareas de la socialdemocracia. Problemas del socialismo. El revisionismo en la socialdemocracia. México: Siglo Veintiuno, 1982, p. 484-548. Artigo publicado pela Die Neue Zeit, vol. XVI, I, em 1897. Neste artigo, Bernstein pretende responder às acusações de filisteísmo dirigidas por Berfort Bax, em seu artigo "Kolonialpolitik und Chauvinismus" (publicado em Die Neue Zeit, n.14, 1896), realizando a defesa da colonização inglesa na Turquia.

${ }^{642}$ A crise contrapunha o governo alemão, que partia em defesa da autonomia nacional do Marrocos - no intuito de afirmar seu poderio frente às antigas potências - ao francês, que planejava o controle político daquele território. Este episódio despertou a população européia para o perigo de novos conflitos internacionais.

${ }^{643}$ Cf. SCHORSKE, C. German social democracy. 1905- 1917: The development of the great schism. New York: Harper Torchbooks, 1972, p.62-63.
} 
militarismo e a exploração colonial $^{644}$, os discursos dos líderes da social-democracia, especialmente de August Bebel e Gustav Noske, mostravam-se cada vez mais condescendentes: alegavam não condenar de antemão a política imperialista, restringindo-se a advogar em nome dos "interesses nacionais" contra os "abusos do militarismo" - a forma de tratamento dos soldados e a rigorosa justiça militar. Na tribuna, Bebel passa a utilizar como argumento para a rejeição das leis de armamentos e das verbas orçamentárias destinadas ao exército e à marinha o simples fato de que o fardo financeiro recairia sobre o povo, através da taxação direta, ao invés de impostos indiretos ${ }^{645}$.

Enquanto a fração parlamentar e a ala direita do partido progressivamente capitulavam perante os apelos nacionalistas e imperialistas do governo, aderindo à preleção pelo fortalecimento do exército alemão e a preparação para eventuais "guerras defensivas", a ala esquerda, composta por personalidades como Karl Liebknecht, Rosa Luxemburg e Hermann Dunker, alertava para a necessidade de congregar a juventude contra o militarismo ${ }^{646}$.

A divisão do partido expressou-se de forma clara no Congresso de Stuttgart da Internacional, em agosto de 1907, onde foram colocados em pauta o militarismo e o colonialismo - a despeito da declarada oposição da delegação alemã ${ }^{647}$. A comissão encarregada da elaboração de uma resolução sobre a questão colonial cindiu-se em uma corrente minoritária, liderada por Ledebour, e uma majoritária, sob a direção de Eduard David, Bernstein e Van Koll. Enquanto a minoria apoiou a manutenção das resoluções dos Congressos de Paris (1900) e Amsterdã (1904) que condenavam os métodos bárbaros da colonização capitalista, "fundados em uma política de roubos e de conquista", a maioria da comissão posicionou-se favoravelmente à "política colonial positiva", enunciando os "benefícios" da colonização para a classe operária ${ }^{648}$. Na ocasião dos debates Van Koll, membro da delegação holandesa, chegara a afirmar:

\footnotetext{
644 “Diesem System keinen Mann und keinen Groschen” (“À este sistema, nem homem nem vintém”) (Scorske, 1982, p. 62).

${ }^{645}$ Schorske, 1982, p.76.

${ }^{646}$ Desde 1904, no Congresso de Bremen, Karl Liebknecht havia apresentado propostas de ações anti-militaristas que foram peremptoriamente rejeitadas pelos líderes do Partido. Isto se repetiu nos congressos de Iena (1905) e de Mannheim (1906). Em 1907 Liebknecht foi condenado a um ano e meio de prisão, acusado de alta traição pelo conteúdo de seu artigo "Militarismo e Anti-Militarismo". Em 1908, Rosa Luxemburg publicou sua brochura "A questão nacional", em defesa da autodeterminação nacional dos países colonizados.

${ }^{647}$ Em março de 1906 os delegados do SPD se opuseram à inclusão da questão militar na pauta do Congresso. Cabe ressaltar que metade da representação alemã no Congresso era composta por pessoas escolhidas entre os sindicatos, o restante vinha de organizações provinciais, principalmente da Baviera, Baden, Württemberg, Hessen, e Hannover.

${ }^{648}$ Cf. CARONE, Edgard. A II Internacional pelos seus congressos (1889-1914). São Paulo: Edusp, 1993.
} 
As colônias são tão antigas quanto a humanidade e continuarão a existir durante muito tempo. Não haverá nenhum socialista que acredite que as colônias são desnecessárias para a ordem futura. (...) Eu pergunto a Ledebour se ele possui coragem para abrir mão das colônias agora, sob o regime capitalista. Talvez ele nos diga o que fará com a população excedente da Europa: em que países aqueles que necessitam emigrar devem procurar suas cidades, se não nas colônias? O que Ledebour fará com a crescente produção da indústria européia, se não forem criados novos mercados nos territórios coloniais? Ele, enquanto socialdemocrata, rejeitará seu dever de trabalhar no sentido de civilizar e desenvolver povos subdesenvolvidos ${ }^{649}$

Os argumentos de Bernstein apontavam no mesmo sentido, exigindo que a socialdemocracia reconhecesse a necessidade das colônias para o avanço da economia alemã e adotasse uma posição ativa, propositiva, para solucionar o problema das colônias. Através de reformas e da constituição de um "Direito Colonial Internacional", a social-democracia deixaria de ocupar uma posição puramente negativa, aproximando-se de uma "política colonial socialista”. Assim, de acordo com Bernstein, dever-se-ia afastar a idéia utópica que implica em abrir mão de colônias:

As colônias estão aqui para ficar: nós devemos nos dar conta disto. Povos civilizados devem exercer certa tutela sobre povos não-civilizados - até mesmo os socialistas devem reconhecê-lo. Deixe que nos baseemos em fatos reais, que nos levarão a opor a política colonial capitalista com uma socialista. Muito de nossa vida econômica depende de produtos das colônias que os nativos não foram capazes de utilizar ${ }^{650}$.

Eduard David também desempenhou um papel relevante na vitória da deliberação prócolonialista dentro da comissão. Segundo sua visão, a política colonial não seria prejudicial aos nativos, porquanto sem a tutela européia cairiam novamente na "barbárie". A "ação civilizadora" européia levaria ao desenvolvimento econômico das colônias e à implantação do capitalismo nestes territórios, pré-condição esta necessária para uma ordem econômica socialista. Para fundamentar sua posição, David utilizou como referência a seguinte declaração de Bebel, apresentada em $1^{\circ}$ de dezembro de 1906:

A efetivação de uma política colonial não é por si só um crime. Uma política colonial pode em certas circunstâncias ser um fator civilizador. Depende de como a política colonial é executada. Se os representantes de sociedades civilizadas vão para povos estrangeiros como amigos, bem-feitores, educadores de humanidade, para ajudá-los a utilizar os tesouros de suas

\footnotetext{
${ }^{649}$ KAUTSKY, Karl. "Socialism and colonial policy”. In: <www.marxists.com>, acesso em 20/2/2006.

${ }^{650}$ Ibid.
} 
terras em seu próprio benefício e de toda a humanidade civilizada, então nós estamos de acordo com isto ${ }^{651}$.

O texto produzido pela corrente majoritária da comissão reproduziu o teor destes discursos, anunciando que "o congresso não rejeita a política colonial, em princípio, posto que pode operar como fator civilizador sob um regime socialista" e que "a ocupação e a exploração de toda terra são indispensáveis ao bem-estar da humanidade" ${ }^{\text {652 }}$. Contudo, tal resolução foi rejeitada pelo Congresso, tendo recebido 108 votos favoráveis e 127 votos contrários (originados principalmente das delegações francesa, inglesa e italiana).

A proposição vitoriosa na Internacional reconhecia que a política colonial capitalista "por sua própria essência conduz necessariamente à servidão, ao trabalho forçado ou à destruição das populações indígenas", pois “em lugar de fazer crescer as forças produtivas, as

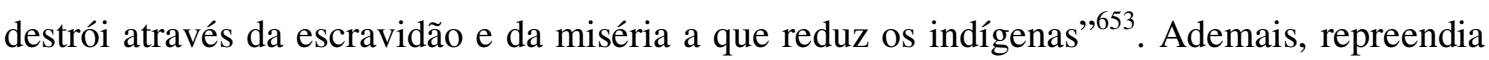
os social-democratas que tentavam encobrir a exploração dos povos nativos sob o pretexto de levarem adiante uma missão civilizadora:

Os socialistas têm o dever de lutar contra a situação de exploração colonial por todos os meios, entre eles o Parlamento, que deve impor reformas para melhorar a sorte dos indígenas, cuidando para manter os direitos destes, impedindo toda exploração, e trabalhando pela educação destes povos pela independência ${ }^{654}$.

Ainda no ano de 1907 a resolução elaborada e apoiada pela maioria da socialdemocracia alemã - que contrariara a deliberação anti-colonial do Congresso de Mainz - foi novamente colocada em questão no Congresso de Essen do SPD. De acordo com Kautsky em sua obra "Socialismo e política colonial" "655, escrita especialmente para a ocasião, as discussões no encontro giraram em torno da tentativa de conciliar as duas posições, minorando e menosprezando os aspectos divergentes. Kautsky, contrariamente, advertira para o fato de que as diferenças apresentadas entre as duas propostas concernindo à questão colonial são mais do que aparentes, repousando em diferentes posturas teóricas e práticas.

Deste modo, Kautsky sublinhara as disparidades existentes entre os socialistas e os revisionistas, ressaltando que as divergências referentes à política colonial contrapõem a visão otimista dos revisionistas - com sua crença na humanização e no progresso da sociedade

\footnotetext{
${ }^{651}$ Ibid.

${ }^{652}$ Carone, 1993, p.91.

${ }^{653}$ Ibid.

654 Ibid.

${ }^{655}$ KAUTSKY, Karl. “Socialism and colonial policy”. In: <www.marxists.com>, acesso em 20/2/2006.
} 
capitalista - à visão "realista", hegemônica no partido, de que o capitalismo seria tão danoso à humanidade que produziria as condições históricas de sua própria superação, mediante uma sucessão de crises econômicas que levariam ao colapso da ordem social vigente e ao surgimento da nova ordem socialista.

Kautsky, contudo, não se deu conta de que a concepção predominante entre os chamados "marxistas ortodoxos", embora substancialmente díspar do ideal revisionista, trazia em si as mesmas vicissitudes decorrentes da ideologia do progresso. Seja pelo prenúncio de uma mudança gradual e progressiva nas entranhas da própria sociedade burguesa, seja pela perspectiva de um movimento natural desaguando inequivocamente no caos de onde brotaria a nova sociedade, ambas interpretações da história redundaram em uma visão fatalista que, conquanto fortalecesse e impulsionasse a luta cotidiana por reformas imediatas, contribuiu para a acomodação e perda de radicalidade do movimento operário ${ }^{656}$.

\subsection{3- Entre o materialismo e o Idealismo}

Como foi visto, a concepção bernsteiniana de uma evolução "orgânica” da sociedade em direção ao socialismo - isto é, a uma ordem social democrática e libertária que conduz a uma distribuição mais justa do produto social, à estabilização da economia e à emancipação econômica e moral - tende a obscurecer a oposição fundamental entre liberalismo e socialismo, sempre presente nas obras de Marx e Engels.

A superestimação da capacidade de adaptação e aperfeiçoamento das instituições liberais no âmbito do modo de produção capitalista, no tocante ao combate aos privilégios de classe e à desigualdade econômica, levou Bernstein a condicionar tais mudanças à elevação moral das demais classes sociais. Tal solução exigira a reavaliação de seu posicionamento teórico em relação ao materialismo histórico, o que o manteve em permanente tensão entre o materialismo e o idealismo. Segundo Bernstein, ao identificar o modo de produção como o fator determinante do desenvolvimento social, o marxismo teria oferecido à teoria social uma nova e inabalável base:

O que Darwin descobriu a respeito da emergência de novas formas e tipos de plantas e animais, Marx desenvolveu no domínio da evolução histórica da sociedade humana. (...)

\footnotetext{
${ }^{656}$ Como conseqüência, a postura passiva e o expectativismo da social-democracia conduziram grande número de suas fileiras a negarem apoio à Revolução Russa e à insurreição alemã de 1919, vistas como momentos de ruptura drástica de um processo predeterminado, desvios do caminho natural.
} 
Assim, a teoria social evolucionista de Marx não pode ser nunca interpretada como uma mera questão de vontade. Em seu curso gradual de desenvolvimento os seres humanos continuam ligados às suas condições de existência. Em outras palavras, é a economia que representa, em último caso, o fator decisivo na história da evolução da sociedade humana ${ }^{657}$.

A ênfase na vinculação da esfera sócio-política com o desenvolvimento econômico seria, para o autor, o aspecto característico e essencial da teoria do desenvolvimento social de Marx e Engels, bem como sua mais valiosa contribuição ${ }^{658}$. Bernstein, entretanto, apresentara reservas ao que considerava um "materialismo puro", determinista ${ }^{659}$. A seu ver, o materialismo puro ou absoluto seria tão especulativo quanto o idealismo puro ou absoluto, pois ambos considerariam idênticos o ser e o pensar, embora sob diferentes perspectivas ${ }^{660}$.

De acordo com Bernstein, portanto, a idéia de que relações de produção determinam as instituições sociais e a direção do pensamento humano facilmente conduziria ao "culto incondicional da matéria" ${ }^{\circ 61}$ :

Pode-se escolher interpretar esta teoria unilateralmente. Por exemplo, pode-se exagerar a força determinante dos fatores técnico-econômicos; pode-se esquecer do fato de que seres humanos possuem cérebros que refletem, desenvolvem ideologias, moralidade e leis ou desconsiderar os efeitos determinantes das idéias sobre o desenvolvimento cultural e a produção. Além disto, pode-se ver o conceito de "modo de produção" superficialmente e assim subestimar a concepção histórica de Marx, uma interpretação que pode levar a uma sobrestimação, ou do momento econômico, ou do papel das idéias. ${ }^{662}$

\footnotetext{
657 BERNSTEIN, E. "Revisionism in Social Democracy". In: Selected writings of Eduard Bernstein: 1900 1921. New Jersey: Humanities Press, 1996, p.69. Artigo escrito em 1909.

${ }^{658}$ Bernstein deixa claro, no entanto, que o materialismo, aplicado à história, não é especificamente socialista, tendo sido difundido nos movimentos liberais dos séculos XVII e XVIII na Inglaterra e na França (Bernstein, 1996, p.46).

${ }^{659}$ Em artigo publicado em 1905 pela Sozialistische Monatshefte, intitulado "De alguém pronunciado morto", Bernstein revela que não pretende contrapor-se ao materialismo histórico, mas sim à interpretação determinista do materialismo histórico: "Materialismo histórico e luta de classes sempre foram colocadas erroneamente como matérias de disputa, pois os revisionistas nunca discordaram que mudanças econômicas influenciam crucialmente a política, a sociedade e o pensamento. $O$ único desacordo era com a extensão dessas forças determinantes sobre fatores ideológicos na história" (Bernstein, 1996, p.58).

${ }^{660}$ BERNSTEIN. "El factor realista y el factor ideológico en el socialismo". In: Las Premisas del socialismo y las tareas de la socialdemocracia. Problemas del socialismo. El revisionismo en la socialdemocracia. México: Siglo Veintiuno, 1982, p. 79. Artigo publicado pela Die Neue Zeit em 1897/1898.

${ }^{661}$ BERNSTEIN, E. "The Marx cult and the right to revise". In: Selected writings of Eduard Bernstein: 1900 1921. New Jersey: Humanities Press, 1996, p.52. Artigo publicado pela Sozialistische Monatshefte., em 1903.

${ }^{662}$ BERNSTEIN, E. "Revisionism in Social Democracy". In: Selected writings of Eduard Bernstein: 1900 1921. New Jersey: Humanities Press, 1996, p.70. Artigo publicado em 1909.
} 
A crítica de Bernstein à concepção materialista da história - a pedra de toque da teoria marxista - incidiria sobre aspectos de uma teoria que, em sua opinião, os próprios fundadores teriam oferecido definições divergentes. Deste modo, a fórmula do materialismo histórico, tal como fora apresentada por Marx e Engels, necessitaria de suplementação, haja visto que ela apenas proporcionaria a base para uma investigação da origem das grandes transformações sociais, faltando-lhe a sutileza necessária para uma explanação minuciosa dos processos evolutivos da história.

Segundo Bernstein, apesar de Marx e Engels terem basicamente compreendido este fato, eles repetidamente negligenciaram importantes fatores na aplicação de sua teoria, dando uma ênfase unilateral aos aspectos econômicos. Esta ênfase excessiva nas causas econômicas teria resultado em uma série de erros de cálculo que levariam a prognósticos sociais equivocados, como, por exemplo, o processo de dissolução e atomização da família ${ }^{663}$, a teoria da luta de classes e a teoria do colapso ${ }^{664}$. Por conseguinte, a influência da ideologia teria sido mal-compreendida nos escritos iniciais de Marx e Engels, ou ao menos não estaria definida adequadamente ${ }^{665}$. Diante desta conclusão, Bernstein, asseverara que qualquer um que pretendesse aplicar o materialismo histórico de Marx e Engels deveria aderir à versão "madura e refinada" que Engels ${ }^{666}$ proporcionou nos seus escritos posteriores, principalmente em seu "Anti-Dühring" 667 :

Quem aplica hoje a teoria materialista da história está obrigado a aplicá-la em sua forma mais avançada e não em sua forma primitiva; tem a obrigação de tomar em conta plenamente, além do desenvolvimento e a influência das forças produtivas e das relações de produção, as concepções morais e jurídicas, as tradições históricas e religiosas de cada época, a influência dos

\footnotetext{
${ }^{663}$ Para Bernstein, a dissolução ou transformação radical da família não estaria no horizonte. A idéia de que só em círculos burgueses se encontraria a forma desenvolvida da família burguesa, verificando-se a ausência de família no proletariado, pelo fato de os vínculos familiares terem sido abalados pela emergência da grande indústria, não se sustentaria. Ao invés de desaparecer a forma tradicional de família burguesa teria sido assimilada pelas demais classes sociais, sendo a família ainda considerada uma "unidade de produção".

${ }^{664}$ BERNSTEIN, E. "The Marx cult and the right to revise". In: Selected writings of Eduard Bernstein: 1900 1921. New Jersey: Humanities Press, 1996, p.48. Artigo publicado pela Sozialistische Monatshefte., em 1903.

${ }^{665}$ Segundo Bernstein, Engels admitiria isto em suas famosas cartas de 1890, como por exemplo a carta a Conrad Schmidt, de 27/10/1890, em que admite a autonomia relativa de elementos da superestrutura, como o Estado, e a noção de "última instância". Cf. BERNSTEIN, E. "To my socialist critics". In: Selected writings of Eduard Bernstein: 1900 - 1921. New Jersey: Humanities Press, 1996, p.37. Prefácio à edição francesa de "Os pressupostos do socialismo e as tarefas da social-democracia", publicado em 1900.

${ }^{666}$ De acordo com Bernstein, "as únicas correções do método de Marx que podem ser encontradas em seu livro são aquelas realizadas pelo próprio Engels" (Bernstein, 1996, p. 37).

${ }^{667}$ Bernstein atribui à Engels a idéia de que quanto maior o domínio humano sobre o desenvolvimento da natureza e da economia, menor os efeitos deterministas das leis objetivas do desenvolvimento histórico. Assim Bernstein interpreta a idéia da realização do socialismo como a "passagem do reino da necessidade para o reino da liberdade".
} 
fatores geográficos e de todos os demais fatores naturais, dos que forma parte também a natureza do homem mesmo e de suas atitudes espirituais. ${ }^{668}$

Assim, embora concordasse que "a economia é sempre o fator decisivo, o ponto arquimediano de todos os grandes desenvolvimentos na história" ${ }^{669}$, Bernstein ressaltara a influência concomitante de fatores não-econômicos sobre o curso histórico. A perspectiva revisionista de Bernstein, portanto, pretendia conciliar materialismo e idealismo, no intuito de abarcar a multiplicidade e complexidade de fatores atuantes na vida social. Neste sentido, argumentara que os fatores sociais, políticos e ideológicos possuiriam certa autonomia, conquanto reconhecesse que "a ordem legal geral, a composição da sociedade, e a natureza das classes são, em última instância ${ }^{670}$, enraizadas nas condições econômicas"671 ${ }^{\text {. }}$

Em sua concepção, o grau de desenvolvimento econômico alcançado pela sociedade alemã conferiria aos fatores ideológicos, e sobretudo aos éticos, uma autonomia muito mais ampla do que no passado. Por conseguinte, o vínculo causal entre o desenvolvimento técnicoeconômico e o desenvolvimento das demais instituições sociais dar-se-ia de forma cada vez mais mediata e menos decisiva ${ }^{672}$.

Ao mitigar a idéia da existência de uma "necessidade férrea da história", Bernstein acreditava conferir à social-democracia um papel mais significativo na evolução gradual ao socialismo do que aquele atribuído pelo "expectativismo revolucionário" dos líderes do partido. Através da atuação partidária e parlamentar seria possível despertar o interesse subjetivo do proletariado - o elemento ético do socialismo. Segundo Bernstein, esta dimensão “ideológica” do socialismo seria incontestável, uma vez que a deliberação de uma meta e a realização de uma idéia não seriam ditadas por uma necessidade objetiva, refletindo antes forças subjetivas ${ }^{673}$.

\footnotetext{
${ }^{668}$ BERNSTEIN. Las Premisas del socialismo y las tareas de la socialdemocracia. México: Siglo Veintiuno, 1982, p.117.

${ }^{669}$ BERNSTEIN, E. “The Marx cult and the right to revise”. In: Selected writings of Eduard Bernstein: 1900 1921. New Jersey: Humanities Press, 1996, p.46. Artigo publicado pela Sozialistische Monatshefte., em 1903.

${ }^{670}$ Pelo fato de a economia continuar sendo o fator decisivo, embora não exclusivo, da história, Bernstein sugeriu a substituição do nome "materialismo histórico", por "concepção econômica da história" (Bernstein, 1982, p. 119).

${ }^{671}$ BERNSTEIN, E. "Revisionism in Social Democracy". In: Selected writings of Eduard Bernstein: 1900 1921. New Jersey: Humanities Press, 1996, p.70. Artigo publicado em 1909.

${ }^{672}$ BERNSTEIN. Las Premisas del socialismo y las tareas de la socialdemocracia. México: Siglo Veintiuno, 1982 , p.119.

673 “Onde a vontade humana não indica a direção (como por exemplo, na competição econômica), pode-se falar confiantemente em uma força objetiva. Mas onde a vontade determina a direção, estamos enfrentando forças subjetivas" (Bernstein, 1996, p.36).
} 
De acordo com Bernstein, o desejo de melhorar as condições de um grupo social específico nunca poderia ser considerado algo "objetivo". Mesmo reconhecendo a influência crucial do ambiente e das condições sociais e naturais na formação da base objetiva da vontade, esta base não seria puramente material: as concepções éticas, legais, religiosas e científicas também desempenhariam papel importante na composição da consciência proletária $^{674}$. O caráter ético das idéias proletárias e, particularmente, do marxismo, residiria no "ponto de vista do proletariado", responsável pelo estímulo moral que daria força ao movimento socialista em sua busca por uma ordem social mais justa e racional. Consoante Bernstein,

Toda teoria do desenvolvimento futuro, por mais materialista que seja, está necessariamente tingida de ideologia. Justamente quando se apóia em fenômenos econômicos concretos, pois as correntes espirituais, os conceitos morais, etc, são coisas absolutamente reais, ainda quando só existam nas cabeças das pessoas. O socialismo marxista não se diferencia de outras teorias socialistas no sentido de que está livre de toda ideologia. Isto não ocorre com nenhuma doutrina orientada para o futuro. Sem ideologia cessa em geral toda a atividade reformista de grande alcance. ${ }^{675}$

Logo, apesar de o movimento socialista estar firmemente ancorado na realidade graças a Marx e Engels que o teriam "removido do domínio da fantasia e o colocado na base da vida social real", devido a seu esforço de fundamentação científica - não poderia prescindir de elementos ideológicos que exprimiriam a nobre meta social da moderna luta de classes. Como doutrina o socialismo representaria, então, a teoria da luta de classes; como movimento não seria nada mais do que a concentração em um objetivo específico, qual seja, a transformação da sociedade capitalista em uma economia organizada coletivamente. ${ }^{676}$

Por conseguinte, o socialismo, seja enquanto teoria de uma ordem social, seja como movimento em direção a uma certa ordem, seria imbuído de um elemento idealista - é algo que deve ser ou o movimento em direção a algo que deve ser. Sem o fator subjetivo - o

\footnotetext{
674 A consideração da ação simultânea de forças materiais e ideológicas afastar-nos-ia tanto do fatalismo histórico quanto do voluntarismo inconsequiente, já que a "vontade é importante, mas para sair vitoriosa depende de certas forças e condições sociais e do grau de sua maturidade" (Bernstein, 1996, p.187).

${ }^{675}$ BERNSTEIN. "El factor realista y el factor ideológico en el socialismo". In: Las Premisas del socialismo y las tareas de la socialdemocracia. Problemas del socialismo. El revisionismo en la socialdemocracia. México: Siglo Veintiuno, 1982, p. 91. Artigo publicado pela Die Neue Zeit em 1897/1898.

${ }^{676}$ BERNSTEIN, E. "How is scientific socialism posible?". In: Selected writings of Eduard Bernstein: 1900 1921. New Jersey: Humanities Press, 1996, p.96. Palestra apresentada na Associação Estudantil para Ciência Social, na Universidade de Berlim em maio de 1901.
} 
interesse e a moral - não haveria qualquer ação social, pois embora a cognição seja capaz de despertar ou liderar o interesse, por si só ela seria inativa.

Uma teoria socialista baseada no materialismo histórico retira o socialismo do domínio da pura ideologia. Ao mesmo tempo mostra que o socialismo não é meramente voluntário, mas que a aspiração ao socialismo, longe de ser casual, é condicionada por circunstâncias históricas particulares. Contudo, estas circunstâncias históricas não podem regular a vontade nem (...) prever o futuro [grifo nosso]. ${ }^{677}$

Como a luta de classes, para Bernstein, representaria um conflito de interesses, sua meta seria igualmente produto das aspirações coletivas do proletariado. Sendo assim, a idéia de um objetivo final em um futuro longínquo perderia quase inteiramente seu caráter científico. Diante disto, quanto mais a teoria socialista fosse influenciada pela "meta final",678, menos científica ela seria. Do mesmo modo, ela ganharia em estatura científica ao limitar-se a simples proposições, baseadas nas tendências e forças empíricas atuantes no momento, que visassem criar, no presente, as condições para uma transformação socialista da sociedade ${ }^{679}$.

Contudo, mesmo limitada a estas tarefas imediatas, a teoria socialista nunca poderia chegar ao patamar de uma "ciência pura". Na concepção de Bernstein, para ser considerado uma "ciência pura" o socialismo teria que renunciar a ser uma doutrina de classe, uma vez que a teoria socialista apenas seria científica se suas proposições pudessem ser aceitas por qualquer "desinteressado e objetivo não-socialista" ${ }^{680}$

Desta forma, Bernstein simultaneamente contestara o caráter científico da doutrina socialista - na medida em que todas as projeções históricas conteriam um elemento hipotético - e exaltara sua fundamentação empírica, característica que a distinguiria de outras doutrinas políticas:

A ciência é livre de tendências; ao meramente reconhecer a facticidade da vida social, ela não pertence nem a partido nem a classe. Ao contrário, o socialismo expressa tendências e como uma doutrina de um partido progressista ele não pode estar vinculado a simples fatos. Mas porque o objetivo do socialismo está de acordo com o desenvolvimento social - como constantemente mostrado pela pesquisa científica relativa às forças motoras da sociedade moderna - é possível para a teoria

\footnotetext{
${ }^{677}$ BERNSTEIN, E. "The Marx cult and the right to revise". In: Selected writings of Eduard Bernstein: 1900 1921. New Jersey: Humanities Press, 1996, p.47. Artigo publicado pela Sozialistische Monatshefte em 1903.

${ }^{678}$ O conceito de "meta final", portanto, seria útil heuristicamente, mas não científico.

${ }^{679}$ BERNSTEIN, E. "The core issue of the dispute: a final reply to the question: how is scientific socialism possible?". In: Selected writings of Eduard Bernstein: 1900 - 1921. New Jersey: Humanities Press, 1996, p.116. Artigo publicado pela Sozialistische Monatshefte em 1901.

${ }^{680}$ Ibid.
} 
socialista, mais do que para qualquer outra teoria política, encontrar demandas científicas. A social-democracia, o partido do socialismo, é então superior a qualquer outro partido político por ajustar seus objetivos e demandas à teoria e exigências das ciências sociais. ${ }^{681}$

Nestes termos, embora não fosse considerado por Bernstein como uma ciência pura ${ }^{682}$, o socialismo se beneficiaria sobremaneira do conhecimento científico dos fatores que contribuem para o desenvolvimento social. A utilização da ciência na escolha dos métodos e estratégias apropriados para a consecução dos objetivos almejados pelos social-democratas seria uma tarefa de extrema importância a ser efetivada pelo partido - pois, para alcançar as metas estipuladas, o socialismo necessitaria compreender as causas e efeitos, forças e interdependências em voga na sociedade. ${ }^{683}$

Sendo assim, apesar de depender de fatores subjetivos, a realização do socialismo não seria nunca uma questão de mera arbitrariedade, porquanto, se subjugassem a ciência à vontade petrificar-se-ia o dinamismo da crítica em um dogmatismo estático. Outrossim, consoante o autor:

Negligenciar esta divisão entre ciência e vontade pode provocar tentativas teóricas rígidas para fazer o socialismo depender de provas de sua necessidade imanente. Tais esforços não podem nunca coincidir com o método científico. Meu kantismo socialista emerge das tentativas realistas de derivar a "razão da vontade socialista" de um método que leva em conta condições históricas realmente existentes e tendências evolucionistas. ${ }^{684}$

A oposição bernsteiniana à cientificidade do socialismo levou-o a questionar o conceito de "socialismo científico", introduzido por Engels. De acordo com sua opinião, além de evocar idéias errôneas, este rótulo também traria um grande risco para o socialismo ao instituir a premissa de imparcialidade científica em um movimento social parcial por natureza, devido à sua perspectiva de classe. Bernstein, então, recomenda que se substitua o termo

${ }^{681}$ BERNSTEIN, E. "How is scientific socialism possible?". In: Selected writings of Eduard Bernstein: 1900 1921. New Jersey: Humanities Press, 1996, p.101. Palestra apresentada na Associação Estudantil para Ciência Social, na Universidade de Berlim em maio de 1901.

${ }^{682}$ Para Bernstein, enxergar o socialismo como uma ciência pura significaria aderir a uma especulação metafísica ao invés de se lidar com a realidade.

${ }^{683}$ BERNSTEIN, E. "How is scientific socialism possible?". In: Selected writings of Eduard Bernstein: 1900 1921. New Jersey: Humanities Press, 1996, p.100. Palestra apresentada na Associação Estudantil para Ciência Social, na Universidade de Berlim em maio de 1901.

${ }^{684}$ BERNSTEIN, E. "Idealism, theory of struggle, and science". In: Selected writings of Eduard Bernstein: 1900 - 1921. New Jersey: Humanities Press, 1996, p.110. Artigo publicado pela Sozialistische Monatshefte.em 1901. 
"socialismo científico" por "socialismo crítico"685, alegando, contudo, que não estaria negando as linhas científicas básicas do marxismo. A seu ver, simplesmente estaria afirmando que o socialismo nunca poderia ser "exclusivamente" científico, sem colocar em xeque a possibilidade de fundamentação científica da teoria socialista. ${ }^{686}$

Mais uma vez, portanto, Bernstein contrapôs-se radicalmente às teses de Marx e Engels. Estes não possuíam quaisquer dúvidas a respeito da cientificidade de seu empreendimento teórico. Para tais pensadores, tratava-se de descobrir, através de investigação empírica, as leis e tendências que governam o modo de produção capitalista e as relações de produção e de troca a ele inerentes:

É, sem dúvida, necessário distinguir o método de exposição formalmente, do método de pesquisa. A pesquisa tem de captar detalhadamente a matéria, analisar as suas várias formas de evolução e rastrear sua conexão íntima. Só depois de concluído esse trabalho é que se pode expor adequadamente o movimento real. Caso se consiga isso, e espelhada idealmente agora a vida da matéria, talvez possa parecer que se esteja tratando de uma construção a priori ${ }^{687}$

Bernstein não realiza a distinção supracitada entre método de exposição e método de pesquisa, passando a vislumbrar, em meio à obra de Marx, um dualismo ${ }^{688}$ que macularia o potencial científico da teoria marxista. Segundo o autor, Marx teria repetidamente ajustado os resultados de sua análise ao objetivo último do esquema demonstrativo, comprometendo assim seus prognósticos relativos ao desenvolvimento do modo de produção capitalista.

Em sua opinião, "no fundo, esta grande mente científica encontrava-se prisioneira de uma doutrina" ${ }^{689}$ que influenciaria o resultado final de sua análise acerca das tendências operantes na sociedade capitalista. Bernstein considerou o capítulo XXIV de "O Capital",

\footnotetext{
${ }^{685}$ Bernstein utiliza "crítica" no mesmo sentido do criticismo de Kant. O autor deriva esta nova nomenclatura da mudança já sugerida por Antonio Labriola, que substituíra o termo "socialismo científico" por "comunismo crítico".

${ }^{686}$ Ibid, p. 113.

${ }^{687}$ MARX, Karl. O Capital: Crítica da Economia Política. vol.1, livro I. São Paulo: Nova Cultural, 1985, p. 20. Posfácio à segunda edição de "O Capital".

${ }^{688}$ Bernstein não foi o primeiro autor a atribuir a Marx uma postura dualista e contraditória. Assim, no Posfácio da segunda edição de "O Capital", Marx constata este fato: "O método aplicado em O Capital foi pouco entendido, como o já demonstraram as interpretações contraditórias do mesmo. Assim, a Revue Positiviste me acusa de que eu, por um lado, trato a Economia metafisicamente e, por outro - adivinhem! -, de que eu me limitaria à mera análise crítica do dado, em vez de prescrever receitas (comteanas?) para a cozinha do futuro" (Marx, 1985, p.18).

${ }^{689}$ BERNSTEIN. Las Premisas del socialismo y las tareas de la socialdemocracia. México: Siglo Veintiuno, 1982, p.266. Ao contrário de Marx, que concebe a passagem do socialismo utópico ao socialismo revolucionário como a passagem de uma ciência doutrinária a uma ciência revolucionária (Marx, 1976, p. 99-100), Bernstein considera como sinônimos "doutrina' e "revolucionarismo".
} 
onde Marx discorrera a respeito da tendência histórica da acumulação capitalista, um exemplo significativo desta contradição:

Em minha opinião o capítulo revela mais um dualismo que circula por toda a obra monumental de Marx (...) que consiste nisto: que a obra pretende ser uma análise científica apesar de tratar uma tese já bem definida muito antes de a obra ser concebida; que esta se baseia em um esquema no qual o resultado a que devia conduzir o desenvolvimento já foi conseguido de maneira antecipada. O retorno ao Manifesto Comunista denota aqui um resíduo efetivo de utopismo no sistema de Marx. ${ }^{690}$

Justamente a censura a este "utopismo", apontado por Bernstein como o responsável pelos desvios especulativos de Marx em direção a uma perspectiva revolucionária, será agora analisada mais detidamente.

\subsection{4- A perspectiva anti-revolucionária e a rejeição da dialética}

Conforme mostramos anteriormente, Bernstein adverte que a teoria "científica" marxista poderia levar ao utopismo quando seus resultados fossem interpretados dogmaticamente. Este tipo de "utopismo" - que consistiria no extremo oposto do velho utopismo - especularia sobre um "hipotético" salto brusco da sociedade capitalista à socialista, mas não discutiria os pormenores desta nova organização social. Diz Bernstein:

A social-democracia moderna se orgulha de haver superado teoricamente o utopismo socialista e, indubitavelmente com razão, na medida em que entra em consideração a elaboração de um modelo de estado futuro. Nenhum socialista responsável descreve atualmente cenas futuras com o objetivo de dar à humanidade uma receita que irá conduzir com maior rapidez e segurança ao objetivo desejado para que reine sobre a Terra a felicidade perfeita. As especulações sobre o futuro que, todavia, são feitas do lado socialista são tentativas de esboçar a traços largos o curso provável do desenvolvimento à ordem socialista, ou quadros esboçados, com mais ou menos talento, de um estado socialista que não pretendem ser outra coisa mais que imagens fantasiosas. ${ }^{691}$

\footnotetext{
${ }^{690}$ BERNSTEIN. Las Premisas del socialismo y las tareas de la socialdemocracia. México: Siglo Veintiuno, 1982, p. 265.

${ }^{691}$ BERNSTEIN. “Observaciones generales sobre el utopismo y el eclectismo”. In: Las Premisas del socialismo y las tareas de la socialdemocracia. México: Siglo Veintiuno, 1982, p.4. Artigo publicado pela Die Neue Zeit, vol.XV, I, em 1896/1897.
} 
Tal "utopismo" consideraria os intentos de reforma da sociedade atual como um simples remendo ou paliativo, enquanto que as verdadeiras soluções seriam trazidas pela sociedade socialista. Assim, estes "utopistas" não se empenhariam em um trabalho sistemático no interior da sociedade capitalista; apenas viveriam o dia "deixando-se levar pelos acontecimentos" ${ }^{, 692}$. Além disto, usariam a referência à luta de classes e ao desenvolvimento econômico para superar todas as suas dificuldades teóricas, adiando todas as soluções para o dia da vitória definitiva do socialismo.

Bernstein apontara como uma das conseqüências desta espécie de "utopismo" o fortalecimento do "romantismo revolucionário", típico dos revolucionários franceses de 1848 e 1871, com sua "desconsideração irracional das condições temporais e espaciais concretas". Este teria vindo à tona novamente com a Revolução Russa de 1917. Para Bernstein, o bolchevismo seria o melhor exemplo dos terríveis efeitos de uma teoria errônea, que seria "cega às leis fundamentais da sociedade e indiferente aos princípios evolucionistas que guiam os seres humanos da barbárie à civilização". 693

$\mathrm{Na}$ visão de Bernstein, portanto, os bolcheviques teriam sido responsáveis pela distorção dos escritos ulteriores de Marx, através da "vulgarização" e "barbarização" do pensamento marxista. Desconsiderariam a visão de $\operatorname{MarX}^{694}$ segundo a qual, até um certo ponto no desenvolvimento capitalista as funções empresariais seriam elementos indispensáveis ao progresso ${ }^{695}$. Para os bolcheviques, segundo a perspectiva bernsteiniana, não haveria "limites históricos ao poder da vontade revolucionária", sendo sua inteira concepção de política obscurecida pela falta de entendimento destes limites ${ }^{696}$. Ao mesmo tempo, utilizariam a violência como fonte criativa e glorificariam a força como remédio social $^{697}$.

\footnotetext{
${ }^{692}$ Ibid.

${ }^{693}$ BERNSTEIN, E. "The bolshevist brand of socialism". In: Selected writings of Eduard Bernstein: 1900 1921. New Jersey: Humanities Press, 1996, p. 190. Artigo publicado em 1921.

${ }^{694}$ Exposta no capítulo XXIV de "O Capital".

${ }^{695}$ Segundo Bernstein, "em tempos remotos, quando a Alemanha já desfrutava de um nível econômico e cultural superior ao da Rússia em 1918, os fundadores do moderno socialismo endossaram uma estratégia proletária de apoio temporário à burguesia progressista" (Bernstein, 1996, p.185).

${ }^{696}$ Cabe ressaltar que Bernstein considerava o bolchevismo como um fenômeno específico da Rússia, que derivaria de longos séculos de absolutismo e convívio com o pior tipo de opressão. Assim, acreditava que ele definitivamente não serviria como modelo a ser imitado pelos países do Ocidente. A classe operária na Rússia estaria lidando com uma fraca burguesia e um regime político totalmente em descrédito e internamente paralisado, ou seja, encontraria uma impotência temporária das outras classes e da autoridade pública (Bernstein, 1996, p.181).

${ }^{697}$ BERNSTEIN, E. "The bolshevist brand of socialism". In: Selected writings of Eduard Bernstein: 1900 1921. New Jersey: Humanities Press, 1996, p. 186. Artigo publicado em 1921.
} 
Bernstein, por fim, acusara os bolcheviques de omitirem todas as partes da teoria marxista que não se encaixavam em sua estratégia. Assim, a tomada revolucionária do poder político, que lhes permitiria direcionar o curso da sociedade, não levaria em conta as exigências e precondições necessárias à transformação socialista, qual seja, a maturidade do proletariado e o desenvolvimento econômico. ${ }^{698}$

Desta maneira, Bernstein opõe aos bolcheviques as mesmas críticas que já havia direcionado ao blanquismo, isto é, a condenação tanto do recurso à "força criadora da violência política revolucionária" como da superposição da mera vontade em detrimento das necessidades econômicas, das relações de força e do nível de desenvolvimento das classes sociais.

De acordo com Bernstein, Marx e Engels teriam propiciado a aproximação do marxismo com o blanquismo ao preservarem o dualismo em sua teoria, tendo realizado a síntese entre a concepção "revolucionária" e a concepção "socialista" - conciliando a luta pela emancipação dos trabalhadores e a ênfase nas precondições econômicas e sociais necessárias a esta emancipação ${ }^{699}$. Contudo, embora em inúmeros escritos estivessem imbuídos deste "espírito blanquista" - como, por exemplo, no programa de ação revolucionária do "Manifesto Comunista”, em "As lutas de classes na França”, em "O dezoito Brumário de Luís Bonaparte" e na "Mensagem à Liga dos Comunistas" - Bernstein alegara que os escritos ulteriores de Engels, no seu entender, teriam abandonado definitivamente a idéia da conquista do poder político através de golpes revolucionários.

As contradições presentes, segundo Bernstein, na teoria marxista seriam a razão para que uma teoria que parte da influência determinante da economia sobre o poder político desembocasse em "uma verdadeira fé milagrosa na virtude criadora do poder político" e na subordinação de todas as pretensões científicas à utopia. Tal ambigüidade teria raízes na incorporação da dialética hegeliana e de suas premissas - notadamente a confluência recíproca dos opostos e a transformação da quantidade em qualidade - ao marxismo. Deste modo, com base na dialética hegeliana, Marx e Engels teriam chegado a elaborar uma doutrina totalmente afim ao blanquismo.

A grande "armadilha" da lógica hegeliana da contradição, em sua opinião, seria responsável pela adoção de construções arbitrárias, uma vez que trataria de adiantar

\footnotetext{
698 Ibid.

${ }^{699}$ BERNSTEIN. Las Premisas del socialismo y las tareas de la socialdemocracia. México: Siglo Veintiuno, 1982, p.136.
} 
dedutivamente certas evoluções com base em princípios predeterminados. Este risco seria tanto maior quanto mais complexo fosse o objeto cuja evolução se pretendesse descrever.

Quando se trata de um objeto normalmente simples, a experiência e o juízo lógico deixam-nos geralmente a salvo do perigo de deixar-nos arrastar, por princípios analógicos como o da "negação da negação", a conclusões inverossímeis sobre suas possibilidades de mudança. Mas quanto mais complexo é um objeto - pelo número e heterogeneidade de seus elementos e pela multiplicidade de suas relações dinâmicas -, a capacidade de tais princípios para revelar algo de sua evolução é menor. Adotá-los como base de dedução significa, então, perder todo critério de valoração. ${ }^{700}$

Assim, Bernstein segue o entendimento de Friedrich Albert Lange, para quem "tanto na vida do indivíduo como na história, o desenvolvimento por antíteses não se apresenta em uma forma tão fácil e radical, nem de um modo tão preciso e simétrico como na construção especulativa"701. Por conseguinte, embora não pretendesse negar todo o método dialético de Hegel, Bernstein opunha-se à sua influência sobre a investigação histórica, rejeitando a filosofia da história hegeliana e sua idéia de desenvolvimento por antíteses.

Após condenar a adesão ao método dialético, que conduziria ao abandono do mundo empírico em prol da especulação metafísica, Bernstein propunha aos socialistas de seu tempo uma maior aproximação com o neokantismo. Assim, aderira ao movimento intelectual de "retorno à Kant", propugnado por acadêmicos alemães ${ }^{702}$ desde a década de $1870^{703}$. Seu ecletismo teria recebido não apenas a influência de Lange ${ }^{704}$ e sua concepção do socialismo como algo eticamente desejável), como também de Hermann Cohen (para quem os postulados éticos tornariam Kant "o verdadeiro fundador do socialismo alemão"), Conrad Schmidt (e sua tentativa de conciliar Marx e Kant) e Ludwig Woltmann (com sua ênfase no retorno à Filosofia Crítica de Kant).

\footnotetext{
700 BERNSTEIN. Las Premisas del socialismo y las tareas de la socialdemocracia. México: Siglo Veintiuno, 1982, p.128.

${ }^{701}$ Ibid.

702 Autores como, por exemplo, F.A.Lange, H. Vaihinger, Hermann Cohen, Paul Natorp, Rudolf Stammler, F.Staudinger e Ernst Cassirer.

${ }^{703}$ Sobre a influência do pensamento de Kant na academia, Ringer observa: "Nem todo professor alemão de filosofia do século XIX foi neokantiano. Mas, entre os que não o foram, um número considerável foi "além de Kant" e ingressou em alguma forma de idealismo. Além disso, ensinou-se tão freqüentemente que a crítica kantiana era um ponto de partida de todo pensamento filosófico que isso influenciou muitos eruditos que não eram filósofos profissionais" (Ringer, 2000, p.98-99).

${ }^{704}$ Tendo como referência obras como "História do materialismo" e "Die Arbeiterfrage".
} 
Bernstein, no entanto, não acolheu completamente a teoria do conhecimento de $\mathrm{Kant}^{705}$, tendo sido muito criticado pelos membros da Escola de Marburg ${ }^{706}$ - que efetivamente retomavam questões epistemológicas e reexaminavam os fundamentos racionais do conhecimento à maneira de Kant - por sua inclinação ao positivismo e ao empirismo ${ }^{707}$. A conjugação do criticismo kantiano com a doutrina positivista tinha como conseqüência a limitação da ciência estritamente ao "estabelecimento de regularidades entre elementos empiricamente observáveis" ${ }^{\text {,708, }}$, retirando, assim, da Ética o status de disciplina racional. Deste modo, o conceito de "Wissenschaft" é empregado por Bernstein em um sentido diverso ao de Kant, na medida em que considera que os juízos morais não poderiam ser compreendidos a priori ou submetidos ao entendimento racional, sendo taxados como nãocientíficos.

Para autores como Peter Gay, esta divergência seria sinal de que Bernstein não teria verdadeiramente compreendido Kant, tendo recorrido ao filósofo como recurso para efetuar uma crítica objetiva e precisa do dogmatismo proveniente da dialética hegeliana ${ }^{709}$. Já de acordo com a análise de Manfred Steger, Bernstein conscientemente teria seguido os passos de Friedrich Albert Lange em sua recusa a qualquer fundamentação metodológica do idealismo ético, o que significaria que não teria falhado em apreender os princípios filosóficos kantianos ${ }^{710}$.

Conforme pretendemos mostrar, o objetivo fundamental de Bernstein em sua polêmica com o marxismo seria - como ele próprio resume em seu prefácio a "Os Pressupostos do Socialismo e as Tarefas da Social-democracia" - "reforçar ao mesmo tempo o elemento

\footnotetext{
${ }^{705}$ Cabe lembrar que Kant realizava uma crítica às investigações empíricas que confundiam de forma simples as impressões e idéias com os objetos físicos ou eventos (a coisa em si). A verdade não seria a correspondência entre a idéia e o objeto, mas a ordenação lógica das sensações e conceitos, de acordo com certos elementos racionais pré-existentes, ou seja, os axiomas necessários a todo o conhecimento. As normas do raciocínio correto assegurariam a ordem e a certeza de nossa experiência (Cf.Ringer, 2000).

${ }^{706}$ Os membros da Escola de Marburg concentravam-se nas críticas às especulações metafísicas, ao empirismo e ao cientificismo. A seu ver, os "problemas de cognição continuavam a exigir uma análise lógica e filosófica", em face do avanço do empirismo e do materialismo. O seu principal representante foi Herman Cohen (Ringer, 2000, p.285-286).

${ }^{707}$ Cf. STEGER, Manfred B. The quest for evolutionary socialism. New York: Cambridge Press, 1997, p.116119.

${ }^{708}$ Steger, 1997, p.117.

${ }^{709}$ GAY, Peter. The dilemma of democratic socialism. New York: Columbia University Press, 1970, p.156.

${ }^{710}$ Steger, 1997, p.118.
} 
realista e o elemento idealista do movimento socialista, combatendo os vícios de uma mentalidade utopista que se encontrariam dentro da teoria socialista". 711

O elemento "realista" do socialismo conduziria o partido a concentrar suas ações em metas "factíveis" e imediatas: a luta por reformas sociais e econômicas, visando à evolução social no sentido da democratização de todas as esferas da sociedade. Já o seu elemento "idealista" serviria para impulsionar o proletariado e as demais classes da sociedade em direção às reivindicações por justiça social e igualdade, materializadas nas metas socialistas.

Desta forma, Bernstein projetara um novo caminho a ser seguido pelo movimento social-democrata que não mais contaria com a perspectiva de um colapso geral do sistema e de subseqüentes revoluções políticas. Em substituição a este prognóstico, Bernstein apresentara a perspectiva de uma evolução "orgânica" e "criativa", partindo do interior do próprio sistema capitalista.

Bernstein atribuíra esta perspectiva evolucionista das sociedades humanas à influência de Marx e Engels, que, a seu ver, subordinariam o desenvolvimento socialista ao desenvolvimento econômico pleno do modo de produção capitalista. Para justificar sua teoria, Bernstein cita a seguinte passagem do prefácio à primeira edição de "O Capital":

Em si e para si, não se trata do grau mais elevado ou mais baixo de desenvolvimento dos antagonismos sociais que decorrem das leis naturais da produção capitalista. Aqui se trata dessas leis mesmo, dessas tendências que atuam e se impõem com necessidade férrea. O país industrialmente mais desenvolvido mostra ao menos desenvolvido tão-somente a imagem do seu próprio futuro [grifo nosso].$^{712}$

Neste sentido, não seria possível saltar estágios evolutivos, passando-se diretamente de um sistema escravista ou feudal ao socialista. Mesmo que a sociedade reconhecesse sua própria lei do movimento ela não poderia "nem pular as suas fases naturais de desenvolvimento nem aboli-las por decreto", embora possa "encurtar e diminuir os espasmos do nascimento" ${ }^{\text {713 }}$. Ademais, Marx e Engels teriam ressaltado a necessidade da consolidação e expansão do modo de produção capitalista para o desenvolvimento das forças produtivas até um nível que "torne possível um desenvolvimento igual e humanamente digno para todos os

\footnotetext{
711 BERNSTEIN. Las Premisas del socialismo y las tareas de la socialdemocracia. México: Siglo Veintiuno, 1982 , p.99.

${ }^{712}$ MARX, Karl. O Capital: Crítica da Economia Política. vol.1, livro I. São Paulo: Nova Cultural, 1985 , p.12.

${ }^{713}$ Marx, 1868, apud Bernstein, 1996, p.73.
} 
membros da sociedade", uma vez que "somente a produção capitalista cria as riquezas e as forças produtivas necessárias para atingir esse objetivo" ${ }^{\text {, } 14}$.

De acordo com Bernstein, justamente a apreensão deste processo evolutivo seria o que de mais forte e profundo diferenciaria Marx dos socialistas passados e de seus contemporâneos:

A sociedade moderna seria como um organismo em perene desenvolvimento que não poderia ser mudado por pura vontade nem petrificada em um determinado momento da história. Marx reconheceu leis sociais inerentes ao desenvolvimento que precisariam ser expostas detalhadamente antes que quaisquer reformas fossem realizadas. ${ }^{715}$

Bernstein não considerara uma simples coincidência o fato de Marx ter escrito seu "Prefácio à Crítica da Economia Política" no mesmo ano em que Darwin publicara seu trabalho sobre a evolução orgânica da natureza. Ambos os escritos teriam emergido "como uma reflexão de uma mesma época histórica, partilhando do mesmo espírito e apresentando a mesma idéia fundamental"716. Desta maneira, Bernstein corroborou e levou às últimas conseqüências a analogia expressa por Engels em seu "Discurso diante da sepultura de Marx", no qual afirmara que assim como Darwin havia descoberto a lei do desenvolvimento da natureza orgânica, Marx haveria descoberto a lei do desenvolvimento da história humana ${ }^{717}$.

Para Bernstein, tanto no prefácio quanto na introdução ao primeiro volume de "O Capital”, Marx teria revelado sua concepção evolucionista, segundo a qual a sociedade presente não seria um cristal sólido, mas um organismo capaz de mudar e que está em constante processo de modificação. Bernstein identifica nestes textos, bem como na explanação a respeito das leis fabris (integrante do primeiro volume do Capital), "passagens que mostram uma forte inclinação reformista no pensamento, em geral revolucionário, de Marx" "718. Ressalta ainda o trecho do prefácio à edição inglesa de "O Capital" - escrito por Engels em 1886 - que, em sua opinião, revelaria que Marx teria chegado à conclusão de que a Inglaterra seria o único país da Europa "onde a inevitável revolução social poderia realizar-se inteiramente por meios pacíficos e legais". Contudo, Bernstein preferiu desconsiderar a frase de Engels que segue a afirmativa anterior: "Certamente ele [Marx] nunca se esqueceu de

\footnotetext{
${ }_{714}^{714}$ MARX; ENGELS. “O Capital de Marx”. In: Obras escolhidas. São Paulo: Alfa-Omega, v.2, 1980, p. 31.

${ }^{715}$ BERNSTEIN, E. "Revisionism in Social Democracy". In: Selected writings of Eduard Bernstein: 1900 1921. New Jersey: Humanities Press, 1996, p. 69. Artigo publicado em 1909.

${ }^{716}$ Ibid.

${ }_{717}^{71}$ Marx; Engels, 1980b, p. 351.

${ }^{718}$ BERNSTEIN, E. "The bolshevist brand of socialism". In: Selected writings of Eduard Bernstein: 1900 1921. New Jersey: Humanities Press, 1996, p. 183. Artigo publicado em 1921.
} 
acrescentar que não esperava que as classes dominantes da Inglaterra se submetessem a essa revolução pacífica e legal sem tentar uma proslavery rebellion"719.

A interpretação evolucionista das obras de Marx efetuada por Bernstein possibilitou a sua adesão a uma concepção linear do progresso social e a uma prática reformista sem necessariamente desvinculá-lo por completo da tradição marxista, ao contrário do que ocorrera com os fabianos, que substituíram a teoria marxiana pelas contribuições de Comte, Darwin e Spencer.

Ao rechaçar a idéia da "ruína necessária" do modo de produção capitalista, Bernstein recorre aos elementos éticos para justificar a transformação social, conferindo às idéias "vida própria" e autonomia. Desta maneira, adere tanto ao idealismo quanto ao positivismo, uma vez que realiza a separação entre juízos de fato e de valor - buscando a complementaridade entre Comte e Kant ${ }^{720}$, igualmente defendida por Max Weber ${ }^{721}$.

Rebelando-se contra o método dialético da teoria marxista, Bernstein excluíra de seu sistema teórico todas as patentes contradições do modo de produção capitalista, explicitadas pela teoria do valor-trabalho e da mais-valia, colocando os antagonismos sociais em segundo plano e partindo em defesa de um reformismo não atrelado ao compromisso revolucionário. Como consequiência, esvaziou a teoria marxista de todo conteúdo crítico e transformador, levando a social-democracia a endossar as teses liberais e a legitimar o sistema capitalista.

Como Mészàros aponta,

O grande atrativo da racionalização ideológica apresentada por Bernstein foi que, por intermédio dela, a tendência do desenvolvimento sócio-econômico e político que então se manifestava - e que, em relação às exigências objetivas da emancipação socialista, era extremamente problemática e contraprodutiva - podia não só ser apresentada como uma tendência totalmente livre de suas implicações negativodestrutivas; pior ainda, podia ser até saudada como um grande

\footnotetext{
${ }^{719}$ Marx, 1985, p.34.

${ }^{720}$ Bernstein defende a existência de uma ciência social empírica, cientificamente neutra, fundamentada em fatos bem delimitados, e de uma moral ideal, pura, absoluta e eterna.

721 Assim como Weber, Bernstein argumenta que a grande complexidade da sociedade humana moderna e a incrível multiplicidade de forças sociais interdependentes que agem sobre ela levariam à divisão fundamental entre ciência e suposição, conhecimento e inclinação (vontade) (Bernstein, 1996, p.106). Propõe ainda que para se apreender as múltiplas formas da realidade social, dever-se-ia recorrer a métodos sincréticos e ecléticos, embora, em se tratando de teoria, fosse freqüientemente impelido pela necessidade a apontar claramente a influência de um único princípio ou força (Bernstein, 1996, p.42). Portanto, na visão de Bernstein, diferentemente das ciências naturais a sociologia não poderia prever com absoluta certeza se uma sociedade imaginada pelo socialismo irá realmente se materializar um dia, a ciência social só poderia antecipar as condições sob as quais o socialismo poderia possivelmente aparecer, estimando a probabilidade desta ocorrência (Bernstein, 1996, p.96).
} 
avanço positivo: a tranqüilizadora prova e a garantia da obtenção do resultado desejado ${ }^{722}$.

Seja pela importância pessoal de Bernstein e seu papel de executor testamentário de Engels, seja pelo fato de representar em suas teses os anseios de uma parcela significativa do Partido Social-Democrata Alemão em processo de expansão, o revisionismo de Bernstein teve ampla ressonância no seio do movimento socialista, sendo responsável pela deflagração do Bernstein-Debatte. Suas idéias, embora aplaudidas por variados grupos - como liberais progressistas, sindicalistas e membros da burocracia do partido -, foram repetidamente condenadas pelos dirigentes partidários e rebatidas por uma vasta gama de intelectuais oriundos das mais diferentes correntes teóricas. No capítulo seguinte procuraremos apresentar algumas destas críticas e suas repercussões no seio do movimento socialista alemão.

${ }^{722}$ MÉSZÀROS, István. O poder da ideologia. São Paulo: Boitempo, 2004, p.377. 


\section{4 - O Bernstein-Debatte e sua Repercussão}

\section{1- A indefinição da "ortodoxia"}

A recepção às idéias de Bernstein entre os dirigentes do partido, no início do século $\mathrm{XX}$, foi marcada por uma clara ambigüidade. Apesar de oficialmente rejeitadas nos textos e congressos da social-democracia alemã, a postura dos principais dirigentes era não apenas de cautela e hesitação como de franca capitulação diante das correntes reformistas ${ }^{723}$. A seu ver, a manutenção da unidade do partido justificaria a adoção de uma postura menos enérgica do que a dispensada aos grupos de inclinação anarquista, que foram expulsos do partido em 1890.

Com a querela revisionista, a preocupação existente desde a fundação do SPD quanto à necessidade de se empreender esforços com vistas à conciliação de tendências divergentes dentro do partido, viu-se redobrada. Por conseguinte, a tática política de se evitar a desagregação a todo custo sobrepôs mais uma vez os interesses práticos imediatos visados pelos líderes do partido à salvaguarda dos princípios socialistas e do "objetivo final" "724.

Neste sentido, Karl Kautsky ${ }^{725}$, considerado o principal porta-voz da "ortodoxia marxista", estando encarregado do estabelecimento da linha teórica oficial do partido, enveredou cada vez mais para a ala direita da social-democracia, apregoando a utilização tática de um "radicalismo passivo". A conciliação entre a adoção de uma fraseologia revolucionária e de uma prática reformista, consubstanciada no apego ao método pacífico e à via institucional, levou à caracterização do SPD como um "partido revolucionário que não faz revoluções" ${ }^{726}$.

Deste modo, "o kautskismo permitia conservar a ficção do caráter revolucionário da social-democracia" 727 , sendo que esta imagem - da qual a direção do partido se servira

\footnotetext{
${ }^{723}$ Em carta a Adler de 8/3/1899, Bernstein observou: "Ninguém crê mais que August [Bebel] na teoria do colapso, mas ninguém se deixa determinar menos que ele em sua ação prática por esta teoria (...) seria capaz de me mandar decapitar se eu o demonstrasse teoricamente o que ele realiza na prática" (Ibid, p.31).

${ }_{724}$ Cf. MUSSE, Ricardo. Do socialismo científico à teoria crítica: modificações na autocompreensão do marxismo entre 1878 e 1937. São Paulo: USP/FFLCH [Tese], 1998, cap.IV.

${ }^{725}$ Karl Kautsky (1854-1938) nasceu em Praga e cursou a Universidade de Viena. Começou seu trabalho como jornalista do SPD em 1880, tornando-se editor da Neue Zeit em 1883. Esta se tornou a principal revista teórica marxista até o seu fechamento, em 1914. Entre seus primeiros escritos de maior peso destacam-se "As doutrinas econômicas de Karl Marx" (1887), "O Programa de Erfurt" (1892), "A revolução social" (1902), "Ética e concepção materialista da história" (1906) e "O caminho do poder" (1909).

${ }^{726}$ Cf. KAUTSKY. "El camino del poder". In: Cuadernos de pasado y presente, n. 68. México, D.F: PYP, 1978.

${ }^{727}$ MATTHIAS, Erich. "Kautsky y el kautskismo" In: La revolución social. El camino del poder. Cuadernos de pasado y presente, n. 68. México, D.F: PYP, 1978, p.20.
} 
conscientemente - seria concebida como indispensável ao processo de integração interna e de cooptação das massas trabalhadoras. A unidade do partido, portanto, seria realizada às custas do sacrifício da práxis revolucionária e da crítica radical ao sistema.

Não obstante a adesão à "tática do desgaste" em detrimento da "tática do aniquilamento", a crítica de Kautsky ao revisionismo lhe valeu o apoio de vários grupos de esquerda. Bernstein, na ocasião das discussões de seu livro observara:

O livro de Kautsky foi recebido com entusiasmo por aqueles que me atacam do campo marxista, e também formou a base teórica do discurso de 6 horas de Bebel contra meu livro no Congresso de Hannover (1899). O trabalho de Kautsky, portanto, incorpora tudo o que é dirigido contra mim neste campo $^{728}$.

O livro de Kautsky - "Bernstein und das sozialdemokratische Programm. Eine Antikritik”, escrito em 1899 - buscava, assim, angariar a simpatia e aprovação da maioria do partido ao apresentar uma série de refutações e objeções à teoria de Bernstein, sem, no entanto, sugerir a sua desqualificação apriorística. Devido à antiga amizade nutrida entre ambos, Kautsky manifestou evidente desconforto ao realizar o "difícil, desagradável e infrutífero" trabalho de crítica ao revisionismo ${ }^{729}$. Logo no início de sua explanação o autor lamenta a existência de divergências de natureza individual, local, profissional e teórica dentro do partido, embora ressalte que tais diferenças seriam não só inevitáveis como necessárias à vida intelectual. Assim, ao mesmo tempo em que saúda a discussão teórica levantada por contribuir para evitar que o partido se converta de uma "legião de lutadores" em "uma assembléia de retóricos", Kautsky demonstra certa irritação com a "perda de tempo" e "desgaste de forças" em conflitos internos que poderiam levar à quebra da unidade, da coesão e da ação comum da social-democracia.

Segundo o autor, os membros da social-democracia deveriam fazer a distinção entre questões táticas e de propaganda: enquanto a propaganda poderia variar, sendo ajustada às condições individuais e locais, fazendo-se uso dos recursos dos quais se dispõe ${ }^{730}$, a tática, isto é, a ação política, deveria ser única ${ }^{731}$. Deste modo, apesar de a unidade de ação não excluir as divergências de pensamento e as diferenças de pontos de vista teóricos, ela

\footnotetext{
${ }^{728}$ BERNSTEIN. "To my socialist critics". In: Selected writings of Eduard Bernstein: 1900 - 1921. New Jersey: Humanities Press, 1996, p.34. Prefácio à edição francesa de "Os pressupostos do socialismo e as tarefas da social-democracia", escrito em 1900 e republicado no mesmo ano na Sozialistische Monatshefte.

${ }^{729}$ KAUTSKY. La doctrina socialista. Buenos Aires: Claridad, 1966, p.17.

${ }^{730}$ Ibid, p. 21 .

${ }^{731}$ Ibid, p.13.
} 
demandaria certo sacrifício da individualidade em nome da organização - sacrifício este ignorado por Bernstein.

Após estas considerações iniciais, Kautsky prossegue em sua tarefa de rebater os argumentos apresentados por Bernstein, que, em sua opinião, não teria exposto sua teoria "de modo claro e conseqüente" ${ }^{, 732}$. A primeira e principal objeção feita pelo autor refere-se ao ataque bernsteiniano ao método marxista. Segundo Kautsky, Bernstein consideraria idênticos o mecanicismo e a hipótese de que o desenvolvimento das forças produtivas determina o desenvolvimento das condições sociais - algo que levaria a inúmeros enganos.

Mas a sociedade não pode abreviar e amenizar as dores do parto das novas fases da evolução social? Certamente, mas como? Encarregando-se da necessidade destas fases. Mas este ato não é uma coisa arbitrária: depende da natureza de nosso intelecto, do poder de nossos meios de investigação, do meio que determina nosso ponto de vista. Não posso descobrir em nenhuma parte menor atenuação, a menor limitação do determinismo. Não confundirá Bernstein o determinismo com o mecanicismo? Sem dúvida, a evolução social não se verifica em nenhum lugar mecanicamente; é o resultado da ação e do esforço de seres conscientes; não se verifica maquinalmente do mesmo modo em todas as partes, mas não quer dizer que não seja necessária. ${ }^{733}$

De acordo com a argumentação de Kautsky, a formulação inicial da concepção marxista da história seria de fato economicista. Contudo, o autor ressalta que Marx e Engels teriam paulatinamente amenizado seu entendimento ${ }^{734}$ em obras posteriores. A perspectiva kaustkiana rejeitava, porém, a interpretação oferecida por Bernstein no tocante à evolução do materialismo histórico, afirmando que tanto Marx quanto Engels teriam permanecido materialistas até o fim de suas vidas. Sendo assim, não seria "a concepção de Marx, mas a de Bernstein, que se modificou (...) alijando-se da concepção marxista"735.

Para Kautsky, portanto, "o grande mérito de Marx e Engels consiste em terem feito entrar, com mais êxito que seus antecessores, os fatos históricos no domínio dos fatos

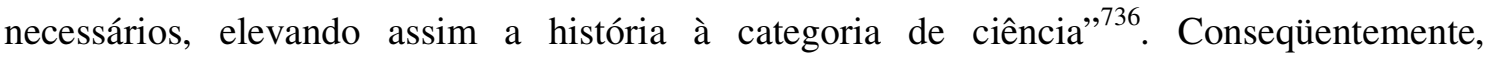
Bernstein erraria ao concluir que a concepção materialista da história não seria em si determinista, uma vez que segundo esta perspectiva, o modo de produção determina "com a

\footnotetext{
732 Ibid, p. 12.

${ }^{733}$ Ibid, p. 25.

${ }^{734}$ Ibid, p. 23.

${ }^{735}$ Ibid, p. 30 .

${ }^{736}$ Ibid.
} 
força de leis da natureza" os fenômenos sociais. No intuito de validar seu argumento, Kautsky faz uso de inúmeras metáforas tomadas das ciências naturais, embora sublinhe que nestas as relações são mais simples e evidentes do que nas ciências sociais ${ }^{737}$.

Aderindo, portanto, a um determinismo econômico e a um naturalismo darwinista, Kautsky oferece sua própria interpretação da teoria de Marx. Cabe lembrar que sua defesa do determinismo histórico - atribuído a Marx e Engels - e a rejeição, inclusive, da diferenciação entre o conceito de "lei" e "tendência" tiveram grande significado e repercussão na teoria e prática pregadas por Kautsky, contribuindo particularmente na justificação de seu "radicalismo passivo". Sua concepção histórica fatalista e anti-dialética, portanto, serviria como base de seu posicionamento político, isto é, de sua apologia ao "expectativismo revolucionário".

Como desdobramento de seu determinismo econômico, a "teoria do colapso" advogada por Kautsky, estaria em franca oposição à perspectiva bernsteiniana e sua análise otimista do capitalismo. Para o autor, o juízo de Bernstein seria motivado por um curto período de prosperidade e alta econômica, carecendo de solidez histórica. Esta situação de momentânea estabilidade econômica e política o teria levado a deduzir precipitadamente uma lei histórica da sociedade moderna e a descartar o materialismo histórico ${ }^{738}$. Neste sentido, Bernstein abriria mão de uma visão mais ampla do processo histórico, resvalando em fórmulas idealistas prenunciadas pelos neokantianos.

Com efeito, Kautsky realiza igualmente uma crítica à concepção moral bernsteiniana, ao rejeitar a existência de uma moral independente acima das forças econômicas, capaz de "vencer as resistências, suavizar as oposições, substituir a luta pela evolução pacífica da reconciliação",739:

A maneira como Bernstein concilia a necessidade histórica e a liberdade moral em sua filosofia da história significa que na prática o Partido Socialista deve aceitar um compromisso entre a necessidade da evolução econômica e a liberdade do utopismo, entre a luta de classes e a reconciliação das classes pelo interesse coletivo ${ }^{740}$.

Cabe lembrar que Kautsky voltaria a concentrar esforços no intuito de desenvolver seus argumentos contra a corrente kantiana em inúmeras ocasiões. Sete anos após a

\footnotetext{
${ }^{737}$ Ibid, p. 28 .

${ }^{738}$ Ibid, p. 33 .

${ }^{739}$ Ibid, p.36.

${ }^{740}$ Ibid.
} 
publicação da "Antikritik", o autor publicou uma obra completa, intitulada "Ética e concepção materialista da história", destinada a rebater aos adeptos do movimento de "retorno a Kant”, na qual ressaltaria as diferenças entre a ética clássica e cristã, a ética iluminista, a ética kantiana, a ética darwinista e a ética marxista. Esta última possuiria um caráter histórico e materialista, baseada em um "instinto social".

Kautsky não somente partira em defesa do materialismo e do determinismo - que vislumbra na obra de Marx - mas também reprovara o descarte da dialética realizado pelo revisionismo. Sob este prisma, o autor levantaria o seguinte questionamento: "O que resta da doutrina marxista quando se retira a dialética, que era "sua melhor ferramenta" e "sua arma mais potente"? "Não eram Marx e Engels dialéticos com toda a força da palavra"? Todavia, em sua resposta, Kaustky mostrara-se titubeante em seu resgate da dialética, encarando-a como mero método de investigação histórica:

É evidente que a dialética não deve ser mais que um instrumento para estudar a realidade e compreendê-la, e não um meio de se evitar estudá-la; que não é uma fórmula mágica que produz por si só resultados definitivos, e que não tem valor a não ser em quanto seus resultados são justificados pelos fatos. Isto se passa com a dialética e com todo o método de observação $^{741}$.

Nestes termos, Kautsky aliara à sua concepção fatalista e determinista do desenvolvimento histórico, uma interpretação particular da dialética hegeliana baseada no "Anti-Dühring" que deságua em uma evolução social e econômica cujos desdobramentos possuem a força de leis naturais. Entretanto, a seu ver, a "teoria do colapso" - expressão esta cunhada pelo próprio Bernstein -, refletiria de forma incorreta o sentido da evolução histórica vislumbrado pelas teses de Marx e Engels. Estas partiriam da premissa que o desenvolvimento avançado do capitalismo geraria crises periódicas que se repetiriam em um tempo relativamente curto, tendo como resultado o agravamento das condições sociais e o acirramento das lutas de classes. Para Kautsky, no entanto, isto não significaria concluir que a revolução social seria precedida inevitavelmente de uma crise industrial ou que o proletariado não poderia conquistar o poder político sem o advento da crise industrial.

De acordo com o autor, Bernstein conferiria à teoria das crises um alcance muito maior daquele originalmente reconhecido, promovendo a confusão entre a idéia de necessidade histórica e de fatalismo, isto é, uma "obrigatoriedade irresistível". Desta forma,

\footnotetext{
${ }^{741}$ Ibid, p.41.
} 
Bernstein acabaria "por criar uma situação em que os homens não terão mais remédio que introduzir o socialismo" ${ }^{, 742}$, culminando na afirmação de que Marx e Engels teriam fundado a necessidade do socialismo sobre aspectos exclusivamente econômicos, e não na "maturidade e poder crescentes do proletariado". Partindo deste ponto de vista, Bernstein acabaria por concluir que o marxismo levaria à concepção de que o capitalismo se destruiria por si mesmo:

Bernstein toma das teorias de Marx o suposto fatalismo da concepção materialista primitiva da história, a idéia de que o homem não é mais do que um simples autômato movido pelas forças econômicas, e descobre nas teorias de Engels, que este reconhece a influência de fatores morais na história (...)". ${ }^{743}$

Kautsky não reconhecia, no entanto, que sua própria interpretação da teoria marxista dava margem à imputação de tais rótulos ao marxismo, por conceber a vitória do proletariado como o resultado necessário de uma lei fatal ${ }^{744}$. Por conseguinte,

vê no modo de produção capitalista o fator que impulsiona o proletariado à luta de classes contra os capitalistas, que aumenta suas forças numéricas, sua coesão, sua inteligência, o sentimento que tem de sua força, sua maturidade política, que acresce cada vez mais sua importância econômica, que faz inevitável sua organização em partido político e a vitória deste partido, e não menos inevitável também o modo de produção socialista, como conseqüência desta vitória (grifo nosso). Esta é a teoria que deve ser examinada em um estudo sobre o futuro do Partido Social-Democrata; ela é a base dos programas dos partidos socialistas; ela é que não podemos perder de vista na discussão seguinte e não a ridícula teoria do colapso, que Bernstein nos atribui. ${ }^{745}$

A exatidão da teoria de Marx, para Kautsky, não seria comprovada pela maior ou menor incidência de crises econômicas, nem pela rapidez da evolução, mas unicamente pelo sentido e direção tomados pela evolução histórica. Nestes termos, as objeções de Bernstein ao marxismo não se mostrariam relevantes, uma vez que os dados por ele coligidos quanto à sobrevivência das grandes e pequenas explorações capitalistas, ao aumento do número de possuidores e à expansão das classes médias, não seriam suficientes para negar esta evolução.

\footnotetext{
${ }^{742}$ Ibid, p. 68 .

${ }^{743}$ Ibid, p. 70 .

744 "Não sabemos nem quando nem como se estabelecerá esta supremacia do proletariado, se será depois de uma grande tormenta ou a consequiência de uma série de catástrofes, ou se se realizará pouco a pouco gradualmente. Tampouco sabemos como serão então a sociedade e o proletariado, porque estes dois fatores se modificam sem interrupção; não sabemos quantas coisas, todavia, imprevistas se realizarão então, nem como se dificultarão ou se facilitarão mais os problemas do regime proletário. Não podemos mais do que reconhecer a lei fatal (grifo nosso) que obrigará ao proletariado vitorioso a substituir a forma de produção capitalista pela forma de produção socialista" (Ibid, p. 226).

${ }^{745}$ Ibid, p. 70.
} 
Além de apontar para a existência de lacunas na crítica de Bernstein à dialética e ao determinismo econômico, Kautsky advertiu ainda para a falta de clareza de sua "nova" teoria do valor, de maneira que não se saberia se esta seria a mesma de Marx, de Jevons, de Buch ou uma síntese das três. Curiosamente, o autor considerara, tal como Bernstein, a teoria da utilidade marginal tão válida quanto a teoria marxista do valor, sendo que ambas representariam partes de um mesmo objeto. Assim, a crítica kautskiana recairia sobre o seguinte ponto: o fato de Bernstein não ter especificado quando seria necessário utilizar a teoria marginalista e quando seria necessário recorrer à teoria marxista:

Não conhecemos um só exemplo, em toda a história da economia política de que um escritor tenha partido em um caso da doutrina de Marx e em outro caso da teoria da utilidade mínima ou que tenha achado possível empregar semelhante método. Bernstein deveria ter dito quando e como isto é possível $^{746}$.

Deste modo, segundo Kautsky, devido a suas falhas e inépcia pessoais, Bernstein não teria chegado a um resultado positivo como crítico da teoria do valor nem como crítico da concepção materialista da história, terminando por substituir a unidade da teoria de Marx por um ecletismo incapaz de preencher as lacunas presentes na teoria de Marx ${ }^{747}$. Em lugar de fornecer uma explicação para o duplo caráter do valor das mercadorias (como valor de uso e valor de troca), Bernstein teria subsumido estas duas dimensões em uma única categoria, denominada "valor econômico", sem, no entanto, apresentar suas bases empíricas.

No tocante à tática política defendida por Bernstein, Kautsky rejeitou sua tentativa de transformar o SPD em um "partido do povo". Embora o proletariado pudesse aliar-se momentaneamente às frações de classes pequeno-burguesas e camponesas para obter certos objetivos políticos e reformas administrativas, não deveria, contudo, cooperar com eles em uma organização duradoura. A preservação do caráter de classe, portanto, possibilitaria a organização do proletariado em um partido político autônomo, consciente da luta de classes que deve travar e de seus objetivos: supressão da propriedade individual dos meios de produção capitalista. Ao contrário, a fusão do proletariado em um partido único com todas as classes populares implicaria na renúncia à revolução e na obrigação de se contentar com algumas reformas sociais.

\footnotetext{
${ }^{746}$ Ibid, p.56.

${ }^{747}$ Ibid, p.59.
} 
Deste modo, segundo o autor, "não se deve considerar que o socialismo aperfeiçoará, mas sim vencerá o liberalismo; não se pode contentar em ser um partido que se limite às reformas democrático-socialistas; deve-se ser o partido da revolução social"748, pois "a revolução social (...) é o objeto fatal ao qual tende toda organização política autônoma do proletariado" ${ }^{\text {749 }}$. Para tanto, Kautsky argumentara que todo partido deveria se dispor à conquista do poder político para "modelar o Estado" e fazer com que as suas forças atuem sobre as formas sociais em adequação às metas partidárias. Assim,

todo partido que tenha vitalidade deve também estar preparado para quando alcançar o poder; deve, pelo mesmo, saber que uso dará à sua força. (...) Um partido que desde o começo declarara que só pode trabalhar utilmente na oposição, que não trata de obter mais que a influência e não o poder, semelhante partido se inutilizaria com essa declaração e perderia completamente a confiança das massas populares. Logo, todo partido deve ter um objetivo final, não como término da evolução social (esta não tem nem término nem objeto final), mas como um fim proposto à sua atividade prática. ${ }^{750}$

Durante a primeira década do século XX, Kautsky manteve praticamente inalterado seu posicionamento teórico radical-revolucionário, embora no tocante à prática do partido defendesse soluções moderadas ${ }^{751}$. Em artigo publicado na Neue Zeit em 24 de novembro de 1900, intitulado "Luta de classes e ética", o autor voltou a ressaltar a missão histórica do proletariado e seu objetivo final, ao proclamar que o proletariado "é a única classe revolucionária, isto é, a única que não se limita a trabalhos menores por vantagens momentâneas, mas luta por um objetivo social, neste sentido é a única classe em que será encontrado idealismo",752.

Para Kautsky, através do método de pensar socialista, a atividade política do proletariado é elevada a um patamar ético mais alto. Nestes termos, "aonde este método de pensar falha, o proletariado pensa da maneira das classes médias", isto é, praticamente. Ao revés, aonde o proletariado pensa como um socialista revolucionário, a luta política é uma luta por princípios: "sua luta diz respeito a toda a vida social (...) não apenas a obtenção de vantagens individuais". Não obstante, a luta por estas vantagens imediatas seria considerada

\footnotetext{
${ }^{748}$ Ibid, p. 226.

${ }^{749}$ Ibid, p. 228.

${ }^{750}$ Ibid, p.224-225.

${ }^{751}$ Isto pode ser constatado em sua postura com relação às greves gerais e aos sindicatos.

752 KAUTSKY. "Class War and Ethics”. In: www.marxists.org.
} 
apenas meios para um fim, promovendo "a regeneração do proletariado para fazê-lo merecedor de sua grande missão histórica"753:

A luta de classes faz crescer uma alta força ética, o sacrifício por um objetivo mais elevado, e a luta revolucionária do proletariado se torna o terreno aonde os campeões do idealismo mais capazes e argutos de todas as classes da sociedade vem a se reunir. (...) Quanto mais revolucionária, mais idealista a luta de classes, mais o objetivo final é acentuado, maior é a força ética, a força para a regeneração moral do proletariado ${ }^{754}$.

O autor, portanto, colocou em xeque a concepção ética bernsteiniana, contrastando-a com o que considera a autêntica "ética socialista". Ao mesmo tempo, diferencia entre a ciência burguesa, conservadora, e a ciência proletária, revolucionária, que consistiria no ponto de vista do proletariado ${ }^{755}$. Desta forma, ressalta que a ciência burguesa vê a catástrofe como perturbação e cessação do processo de evolução, e, assim, "recua instintivamente diante de qualquer progresso no terreno político, social e até mesmo científico, porque sente que qualquer progresso, em vez de servi-la, lhe será infinitamente prejudicial”,756.

Segundo Kautsky, para Marx, a luta de classes não passaria, ao contrário, "de uma forma particular da lei geral da evolução natural, que nada pode ter de pacífico”:

Aos seus olhos (...) a evolução é dialética, isto é, é o produto de uma luta entre antinomias que se manifestam necessariamente. Mas toda luta entre elementos irreconciliáveis não pode deixar de terminar pela derrota de um dos antagonistas, isto é, por uma catástrofe. É possível que essa catástrofe se prepare lentamente, que a força de um dos combatentes aumente de modo insensível, ao passo que a do outro diminua de maneira absoluta ou relativa; pouco importa, pois o aniquilamento de uma das partes se torna, por fim, inevitável, não como um fato natural, mas porque há uma luta e porque a força de um acaba por vencer a do outro ${ }^{757}$.

Neste sentido, Kautsky destaca que, para o proletariado, "o que é mais urgente e mais decisivo é a conquista do poder político", embora a emancipação econômica da classe operária seja o fim principal ao qual todo movimento político deva estar subordinado como um simples meio secundário ${ }^{758}$. Sendo assim, a tentativa de Bernstein de revisar a teoria

\footnotetext{
753 Ibid.

${ }^{754}$ Ibid.

${ }^{755}$ Discurso pronunciado em 1908, por ocasião do $25^{\circ}$ aniversário de Marx e publicado em brochura, sob o título "Die historische Leistung von Karl Marx" (KAUTSKY. As três fontes do marxismo. São Paulo: global, 1982, p.26).

756 Ibid, p. 27.

${ }^{757}$ Ibid, p. 26.

${ }^{758}$ Ibid, p. 67.
} 
marxista teria como conseqüência o "esvaziamento" do próprio marxismo e a fragmentação da classe operária ${ }^{759}$ :

Os operários sabem perfeitamente qual é a força que criam pela sua união. A seus olhos, essa união vale mais do que qualquer clareza teórica e amaldiçoam todas as discussões teóricas, se estas ameaçam conduzir a uma cisão. Têm razão, porque a procura de clareza teórica levaria ao contrário da finalidade almejada, enfraquecendo a luta da classe proletária, em lugar de fortalecê-la. Um marxista que levasse uma divergência teórica ao ponto de provocar uma cisão numa organização de combate proletária, não agiria de conformidade com a doutrina de Marx, para quem qualquer passo para a frente num movimento real tem mais importância do que uma dúzia de programas ${ }^{760}$.

O contundente rechaço de Kautsky ao revisionismo e sua defesa de uma evolução histórica originada de uma sucessão de catástrofes levou a que os dirigentes da socialdemocracia vetassem a reimpressão de seu livro "O caminho do poder", escrito em 1909. Tais dirigentes apresentaram como justificativa a necessidade de se evitar um processo contra o partido e o fechamento dos jornais.

Se nesta época, Kautsky revelara-se um crítico da ala moderada, sua concepção teórica e prática sofreu uma considerável transformação. Após haver aderido à ala direitista, votado os créditos de guerra em agosto de 1914 e se posicionado contra os apelos dos revolucionários pela convocação de uma greve geral contra a guerra, sua postura tornou-se cada vez mais conservadora. Tal mudança fez-se evidente a partir da deflagração do processo revolucionário na Rússia em 1917. Em sua obra "A ditadura do proletariado", escrita em 1918, Kautsky realiza um severo ataque ao partido bolchevique, anunciando que

Em verdade não é o socialismo nosso objetivo final, mas a abolição de "toda espécie de exploração e de opressão, quer seja dirigida contra uma classe, um partido, um sexo ou uma raça". Por essa luta [de classes], nós nos propomos a estabelecer um modo de produção socialista, dado que parece ser, hoje, o único meio que corresponde às condições técnicas e econômicas dadas para conseguir nosso fim. Se se chegasse a demonstrar que estamos errados em não acreditar que a liberdade do proletariado e da humanidade em geral possa realizar-se, unicamente, ou mais comodamente, na base da propriedade privada dos meios de produção - como Proudhon continuou a crer - então deveríamos rejeitar o socialismo, sem

\footnotetext{
${ }^{759}$ Em carta a Adler, de 11/2/1915, Kautsky conclui que: "aqueles ao redor de David e dos sindicalistas acreditam que o momento é oportuno para livrarem o partido de todo "marxismo". Eles não conseguirão nos expulsar simplesmente, mas eles dominam o Executivo e preenchem um cargo atrás do outro com sua gente. Assim, estabeleceram um terrorismo quase intolerável”. (Steger, 1997, p.216).

${ }^{760}$ Kautsky, 1972, p. 72.
} 
renunciar, entretanto, a nosso fim, e deveríamos fazê-lo, precisamente, no interesse de nosso objetivo final ${ }^{761}$.

O autor passara então a realizar a defesa dos meios pacíficos e a rejeitar uma idéia de "ditadura do proletariado" que não incluísse a forma democrática-parlamentar de governo. Deste modo, em sua concepção "não se poderia opor democracia e socialismo e dizer que um é o meio e o outro é o fim", uma vez que "todos os dois são meios para um mesmo fim"762. A seu ver, o socialismo como meio de emancipação do proletariado seria impensável sem democracia, contudo "uma democracia pura" seria possível sem o socialismo ${ }^{763}$.

A visão da democracia parlamentar como único instrumento para se chegar ao socialismo e propiciar o processo de "amadurecimento do proletariado"764, o que havia sido defendido anos antes por Bernstein, passara então a ser incorporado aos discursos de Kautsky. Com efeito, sustentara que para que o socialismo pudesse se desenvolver seria preciso que "a maturidade do proletariado se acrescente à maturidade das condições e ao nível necessário de desenvolvimento industrial". Para tanto a democracia seria indispensável, posto que não somente permitiria, mais do que qualquer outro meio, acelerar o processo de amadurecimento do proletariado, como ainda ajudaria a reconhecer o momento em que essa maturidade seria alcançada ${ }^{765}$. Assim, se o proletariado fosse "bastante forte e inteligente para tomar em mãos a organização social" ${ }^{\prime 766}$, ele poderia então transferir a democracia do plano político para o econômico.

Deste modo, Kautsky adere ao reformismo que anteriormente havia criticado, contrapondo o "método pacífico" - "a tática menos dramática", "teatral" e que "exige menos sacrifícios" - a "métodos revolucionários", agora vistos como demasiadamente "violentos"767: confio que a revolução social do proletariado revista formas inteiramente diferentes das que tomou a revolução burguesa; que a revolução proletária, contrariamente à revolução burguesa, possa ser alcançada por meios "pacíficos" de natureza econômica, legislativa e moral - e não recorrendo aos

\footnotetext{
${ }^{761}$ KAUTSKY. A ditadura do proletariado. São Paulo: Ed. Ciências Humanas, 1979, p. 5-6.

762 Ibid, p.6.

763 Ibid.

764 Ibid, p.9.

765 Ibid, p. 17

${ }^{766}$ Ibid, p. 16.

${ }^{767}$ Em artigo escrito na ocasião da morte de Lênin (em 28 janeiro 1924), Kautsky opôs-se mais uma vez ao regime bolchevista, comparando a figura de Lênin a de Bismarck, em razão de seu "autoritarismo": "Lênin começou por garantir ao proletariado plena liberdade. Mas as conseqüências políticas e econômicas de seu método começaram a restringi-la" ("Epitaph of Lênin", revista Izvestia. In: www.marxists.org).
} 
meios da força física - em todo o lugar onde a democracia esteja enraizada ${ }^{768}$.

Em resposta ao livro de Kautsky, Trotsky endereçou-lhe inúmeras críticas, reunidas em um artigo intitulado "Terrorismo e comunismo" (1919). Nesta obra, Trotsky denunciara o caráter conservador da social-democracia alemã, que sob o pretexto de salvaguardar a "democracia", acomodava-se à ordem burguesa e legitimava e prolongava a opressão da classe trabalhadora.

A guerra civil revestiu na Alemanha um caráter cada vez mais renhido. $\mathrm{O}$ aparente poder da antiga organização socialdemocrata do partido e dos sindicatos, longe de facilitar a passagem pacífica e "humanitária" para o socialismo, - o que resultaria da atual teoria de Kautsky - foi, pelo contrário, uma das principais causas do prolongamento da luta e do seu crescente agravamento. Quanto mais a social-democracia se tornava inerte e conservadora tanto mais o proletariado alemão que ela traiu tem de despender forças, sangue, vida, nos seus perseverantes ataques contra a sociedade burguesa, a fim de se criar, no decorrer dessa mesma luta, uma nova organização suscetível de o conduzir à vitória definitiva. O complot dos generais alemães, os seus sucessos momentâneos e as suas conseqüências sangrentas, revelaram novamente a que mesquinha e insignificante mascarada se reduziu o que chamam a democracia nas condições geradas pelo desmoronamento do imperialismo e pela guerra civil. Sobrevivendo a si própria, a democracia não resolve nenhum problema, não apaga nenhuma contradição, não cura nenhuma ferida, não previne contra as insurreições da direita nem da esquerda: é impotente, insignificante, enganadora e só serve para enganar as camadas atrasadas da população e nomeadamente a pequena burguesia $^{769}$.

Portanto, de acordo com Trotsky, as "formas democráticas”, caracterizadas pela sujeição da política aos meandros burocráticos e "malabarismos parlamentares", tão arduamente defendidas pela ideologia tradicional dos partidos da Segunda Internacional, teriam perdido todo o significado, conduzindo à inércia conservadora. O kautskismo "medroso", "equívoco" e "hipócrita" só levaria, então, ao "ceticismo pequeno-burguês", à "apatia" e ao "medo",770. Por conseguinte, os dirigentes dos partidos social-democratas não ousando, não sabendo ou não querendo tomar o poder no momento mais crítico da história da

\footnotetext{
${ }^{768}$ Kautsky, 1979, p.26.

${ }^{769}$ TROTSKI, Leon. O Anti-Kautsky. Coimbra: Nosso tempo, 1972, p. 12-13.

${ }^{770}$ Ibid, p. 14.
} 
humanidade, teriam conduzido o proletariado ao extermínio mútuo, transformando-se na "força decisiva da contra-revolução"771.

O "conservadorismo repulsivo" e a "inépcia vil" dos líderes da social-democracia teriam, portanto, como conseqüência a própria adesão à política imperialista ${ }^{772}$ e a defesa da ordem burguesa. Embora a rotina e inércia do "rame-rame quotidiano" e a "hipnose da legalidade" não tivessem dominado por completo o proletariado, elas constituiriam um obstáculo para que ele enveredasse conscientemente e sem reservas pelo caminho das lutas revolucionárias abertas, levando-o a hesitar nos seus últimos momentos de equilíbrio instável $^{773}$. Com efeito, o próprio partido passaria a criar empecilhos à emancipação proletária:

Um partido socialista que se beneficie de uma influência tradicional, mas que não se aperceba do que se passa à sua volta, que, por não compreender a situação revolucionária, não pode achar solução para ela, que não tem fé em si nem no proletariado, um partido desta natureza, na nossa época, constitui o mais deplorável obstáculo histórico, uma causa de perturbação e de um caos destruidor (grifo nosso). É esse o papel de Kautsky e dos seus discípulos, hoje. Ensinam o proletariado a não ter confiança em si próprio mas a considerarem verdadeira a imagem que lhes restitui o imperfeito espelho da democracia, reduzido hoje a estilhaços pela bota do imperialismo. $\mathrm{Na}$ sua opinião, a política revolucionária do proletariado não deve ser determinada pela situação internacional, pelo desmoronamento real do capitalismo, pela ruína social que daí resulta, pela necessidade objetiva do domínio da classe operária que clama a sua revolta nos escombros fumegantes da civilização capitalistas; nada disto deve determinar a política do partido revolucionário proletário; ela depende unicamente do número de votos que lhe reconhecem, a partir dos seus cálculos inteligentes, os escribas do parlamentarismo. ${ }^{774}$

Assim como Trotsky, Lênin assumiu igualmente a tarefa de rebater ferozmente às críticas de Kautsky. Desde 1902 Lênin havia se posicionado no debate contra o revisionismo, que a seu ver seria resultado de uma "tendência transplantada diretamente da literatura

\footnotetext{
${ }^{771}$ Ibid, p. 25-26.

772 "A inércia das forças políticas que se revelaram incapazes de destruir os velhos grupos de classe; a inércia, a estupidez e a traição dos partidos socialistas dirigentes, assumindo de fato a defesa da sociedade burguesa, tudo isto conduziu à revolta espontânea, elementar, das forças produtoras sob os aspectos da guerra imperialista" (Ibid, p.26).

773 Ibid, p. 27.

${ }^{774}$ Ibid, p.28-29.
} 
burguesa para a literatura socialista"775. Sendo assim, para Lênin o "social-reformismo burguês" nada mais seria do que uma crítica burguesa das idéias fundamentais do marxismo, cuja demonstração prática seria o "bernsteinianismo prático" de Millerand e a conversão do partido em um partido de reformas, que pregue a colaboração democrática das classes, a democracia como supressão da dominação das classes, a não-oposição entre liberalismo e socialismo e a negação da luta de classes, do objetivo final, da pauperização e da proletarização.

Em “Que fazer?", Lênin advertira para o fato de que os grupos revisionistas estariam se expandindo em praticamente todos os partidos social-democratas europeus, sob a bandeira do repúdio ao marxismo "dogmático". Desta maneira, bernsteinianos, fabianos, ministerialistas franceses, legalistas russos, entre outros, constituiriam "uma só família", elogiando-se mutuamente e aprendendo uns com os outros, internacionalmente ${ }^{776}$. Diante desta expansão a batalha contra o oportunismo socialista só poderia ser realizada igualmente a nível internacional.

Em "Um passo em frente, dois passos atrás" (1904), o autor apontava sua divergência em relação à posição sustentada por Plekhánov (em artigo de novembro de 1903, intitulado "O que não se deve fazer"), que advogara pela necessidade de se fazer o máximo de concessões pessoais a fim de "evitar o mal maior": a cisão do partido. Ou seja, Plekhánov argumentara que, em termos práticos, não se deveria ser "inoportunamente áspero" e intransigente com os revisionistas ${ }^{777}$.

Em sua discussão com Kautsky, consubstanciada no artigo "O Estado e a Revolução" (1917), Lênin contrapôs-se à postulação kautskiana segundo a qual a ditadura do proletariado

\footnotetext{
${ }^{775}$ LÊNIN. “Que fazer?”. In: Obras escolhidas. $3^{\text {a }}$ ed. São Paulo: Alfa-Omega, v. 1, 1986, p. 84.

${ }^{776}$ Ao examinar o fenômeno revisionista, que considerava reflexo de uma infiltração inevitável de mentalidade pequeno-burguesa no seio dos grandes partidos operários, Lênin escreveu: "A divisão no seio do socialismo internacional contemporâneo estabelece-se hoje, nos diversos países do mundo, essencialmente numa mesma linha, o que mostra um formidável passo em frente que se deu em comparação com o que ocorria há trinta ou quarenta anos, quando lutavam nos diversos países tendências heterogêneas dentro de um movimento socialista internacional único (...) O caráter inevitável do revisionismo é determinado pelas suas raízes de classe na sociedade atual. O revisionismo é um fenômeno internacional. Para nenhum socialista um pouco informado e consciente pode existir a menor dúvida de que a relação entre ortodoxos e os bernsteinianos na Alemanha, entre os guesdistas e os jauressistas (agora, em particular, os broussistas), em França, entre a Federação SocialDemocrata e o Partido Trabalhista Independente, em Inglaterra, entre De Brouckère e Vandervelde, na Bélgica, os integralistas e os reformistas, em Itália, os bolcheviques e os mencheviques na Rússia, é por toda a parte essencialmente a mesma, e não obstante a gigantesca diversidade das condições nacionais e dos fatores históricos na situação atual de todos esses países". LÊNIN. "Marxismo e revisionismo". In: Obras escolhidas. $3^{\mathrm{a}}$ ed. São Paulo: Alfa-Omega, v. 1, 1986b p.43-45.

${ }^{777}$ LÊNIN. "Um passo em frente, dois passos atrás". In: Obras escolhidas. $3^{\mathrm{a}}$ ed. São Paulo: Alfa-Omega, v. 1, 1986, p.336.
} 
contrariaria a democracia. Consoante o autor, Kautsky ter-se-ia desviado para o lado dos democratas pequeno-burgueses, recaindo no oportunismo. Sua nova postura antirevolucionária o levara ao extremo de ora esquecer, ora deturpar a experiência da Comuna de Paris, vista por Lênin como um modelo de reorganização socialista da sociedade a um só tempo socialista e democrática. Com efeito, repetindo Pannekoek, Lênin atribuíra a Kautsky a propugnação de um "radicalismo passivo" através da difusão de uma "teoria da espera inativa" que abandonaria inteiramente o marxismo e passaria ao oportunismo ${ }^{778}$.

Deste modo, tal como Trotsky ${ }^{779}$, Lênin acusara Kautsky de haver "deturpado e vulgarizado" a teoria marxista, fazendo desaparecer a necessidade de destruição da máquina do Estado (incluindo o exército permanente, a polícia e a burocracia) e, assim, transformando a "conquista" do poder político na "simples obtenção da maioria". Ao invés da conquista do poder do Estado pregar-se-ia a modificação da correlação de forças nos quadros da república parlamentar burguesa ${ }^{780}$, o que na realidade significaria uma concessão aos oportunistas:

Isto não é uma polêmica contra Bernstein, mas, no fundo, uma concessão a ele, uma entrega de posições ao oportunismo, pois, de momento, os oportunistas não precisam de nada mais do que "deixar muito tranqüilamente ao futuro" todas as questões fundamentais das tarefas da revolução proletária ${ }^{781}$.

A perspectiva leninista, desta forma, considerava que nos interstícios do sistema capitalista o democratismo estaria limitado, comprimido, truncado e mutilado por todo o ambiente de escravidão assalariada, de necessidade e miséria das massas ${ }^{782}$. A opressão do proletariado sob a dominação burguesa, portanto, colocaria por terra a "veneração supersticiosa do Estado".

É relevante destacar igualmente a controvérsia emergida entre Lênin e Kautsky no tocante à interpretação do imperialismo enquanto fenômeno histórico. Para Kautsky o imperialismo não seria a nova fase do capitalismo, mas apenas uma de suas possíveis formas

${ }^{778}$ LÊNIN. “O Estado e a revolução”. In: Obras escolhidas. 2a ed. São Paulo: Alfa-Omega, v. 2, 1988, p.298.

779 Trotsky chegou a afirmar que "os políticos rotineiros, incapazes de abarcar o processo histórico na sua complexidade, nas suas contradições e nas suas discordâncias interiores, imaginaram que a história preparava simultânea e racionalmente, em toda a parte ao mesmo tempo, o advento do socialismo, de modo que a concentração da indústria e a moral comunista do produtor e do consumidor tivessem podido evoluir e amadurecer com as charruas elétricas e as maiorias parlamentares. Daí vem uma atitude puramente mecânica em relação ao parlamentarismo que, aos olhos da maioria dos políticos da II Internacional, indicaria um grau de preparação da sociedade para o socialismo do mesmo modo que um manômetro indica a pressão do vapor. No entanto, nada mais absurdo do que uma tal representação mecânica do desenvolvimento das relações sociais (grifo nosso).” (Trotsky, 1972, p.25).

${ }^{780}$ LÊNIN. "O Estado e a revolução". In: Obras escolhidas. 2a ed. São Paulo: Alfa-Omega, v. 2, 1988, p.299.

${ }^{781}$ Ibid, p. 295.

${ }^{782}$ Ibid, p.300. 
políticas. Todavia, acreditava que a disputa e os conflitos entre nações tenderia a desaparecer em função da adoção de uma política de conciliação que deixaria intactas as bases da economia capitalista. O "ultra-imperialismo", vislumbrado por Kautsky, representaria a união dos imperialismos de todo o mundo - em lugar da luta entre eles - e a cessação das guerras sob o capitalismo. Assim, a exploração geral do mundo pelo capital financeiro, unido internacionalmente, atenuaria (ao invés de acentuar) as contradições da economia mundial ${ }^{783}$.

Partindo de uma interpretação diametralmente oposta, o pensamento leninista apregoava que o imperialismo seria uma fase superior do capitalismo, isto é, "a véspera da revolução social do proletariado". Na medida em que promoveria a concorrência de vários países em escala internacional e o predomínio do capital financeiro sobre o comercial, o imperialismo prenunciaria uma época de intenso conflito em que as alianças interimperialistas só poderiam ser concebidas como "tréguas entre guerras"784.

A principal e mais conhecida investida de Lênin contra Kautsky foi expressa em seu texto "A revolução proletária e o renegado Kautsky", de 1918. Neste, Lênin responsabiliza a ruptura dos partidos social-democratas em relação ao marxismo pela bancarrota da Segunda Internacional. Embora aqueles conferissem um "reconhecimento verbal" ao marxismo, esvaziavam-no de sua alma revolucionária, descartando os meios revolucionários de luta.

Tal crítica ao chamado "marxismo ortodoxo" foi aprofundada no início da década de 1920 pelo teórico e jurista Karl Korsch. Este atentou para o fato de que a rejeição ou desconsideração do pensamento dialético entre os membros da Segunda Internacional culminara na descaracterização da concepção marxista produzindo desvios na doutrina. Neste sentido, a concepção de Kautsky representaria o despojamento do caráter essencialmente revolucionário do marxismo e da equívoca suplantação da teoria da luta de classes $^{785}$. Neste sentido, o marxismo ortodoxo de Kautsky seria "a outra face, o reflexo teórico e o complemento simétrico do revisionismo de Bernstein"

A seu ver, a postura assumida pela ortodoxia dera início a uma crise dentro do marxismo, suscitando o declínio de sua posição hegemônica no âmbito do movimento operário. Segundo Korsch, seria imperativo um esforço de reforma da teoria e prática marxistas e a modificação de sua posição quanto ao Estado burguês, de modo a privilegiar a

\footnotetext{
${ }^{783}$ LÊNIN. "O imperialismo, fase superior do capitalismo". Obras escolhidas. $3^{\mathrm{a}}$ ed. São Paulo: Alfa-Omega, v. 1, 1986, p.646. Escrito de 1916.

${ }^{784}$ Ibid, p.664.

${ }^{785}$ KORSCH, Karl. Marxisme et philosophie. Paris: Les éditions de minuit, 1964, p.29.

${ }^{786}$ Ibid, p.33.
} 
ação subjetiva da classe trabalhadora e recuperar o elemento crítico, pragmático e ativo da teoria social de Marx contra a teoria cientifico-positivista da Segunda Internacional. Seria igualmente indispensável para o avanço do movimento a reunificação entre a teoria e a prática - cuja separação existiria desde o princípio do movimento:

A concepção materialista da história, que se originou no período revolucionário anterior a 1850 como parte integrante direta da ação subjetiva da classe revolucionária e que continuamente criticou na teoria e subverteu na prática as falsas aparências e os aspectos transitórios de todas as condições sociais imperantes, posteriormente se desenvolveu até se converter, cada vez mais, em uma teoria contemplativa e meramente abstrata acerca do curso objetivo da evolução social, determinado por leis exteriores ${ }^{787}$.

Assim, de todas as formas assumidas pelo marxismo, o marxismo ortodoxo apareceria como a mais nociva para o movimento progressista da classe proletária, pois além de o haver petrificado como uma mera ideologia, também o teria transformado em uma amarra para o ulterior desenvolvimento da teoria e da prática da luta da classe proletária ${ }^{788}$. Como nos lembra Ricardo Musse,

No combate a esse "marxismo vulgar" que pretende suprimir, sem mais, a filosofia e a ideologia, Korsch procura restabelecer alguns dos princípios do materialismo dialético, em especial, a teoria que afirma que as formações espirituais devem ser concebidas, teoricamente, e tratadas, na prática, como realidades sociais. Concede, assim, à filosofia (e às demais formações ideológicas) a possibilidade de "exprimir, na sua forma particular, o todo da sociedade burguesa. Juntamente com a arte e a religião, a filosofia pertenceria, portanto, à "estrutura espiritual da sociedade burguesa, que corresponde à estrutura econômica dessa sociedade, no mesmo sentido em que sobre esta estrutura econômica se ergue a superestrutura jurídica e política desta sociedade ${ }^{789}$.

Com efeito, Korsch, assim como Lukács, entreviu a necessidade do resgate da filosofia como arma de combate no campo ideológico, no intuito de forjar uma teoria mais adequada à ação revolucionária, traduzindo uma posição política revolucionária para o terreno da luta ideológica ${ }^{790}$.

\footnotetext{
${ }^{787}$ KORSCH. Teoría marxista y acción política. México: Pasado y Presente, 1979, p. 169.

${ }^{788}$ Ibid, p. 171.

${ }^{789}$ MUSSE, Ricardo. Do socialismo científico à teoria crítica: modificações na autocompreensão do marxismo entre 1878 e 1937. São Paulo: USP/FFLCH [Tese], 1998.

${ }^{790}$ Ibid.
} 
Como observou Matthias, a doutrina de Kautsky, cuja "íntima essência revisionista correspondia ao reformismo mascarado da prática do partido, com sua fraseologia revolucionária, mas não comprometida", não estava certamente em condições de satisfazer a pretensão oficial de ser uma teoria da política social-democrata ${ }^{791}$. Frente às vacilações e hesitações esboçadas pela direção do Partido Social-Democrata Alemão na querela revisionista, uma corrente mais radical começou a se organizar dentro do partido, a fim de defender os princípios revolucionários, alvo dos ataques de Bernstein.

Conforme veremos a seguir, enquanto os "ortodoxos" concentravam seus esforços na unificação do movimento com vista à salvaguarda da tática eleitoral, as alas à esquerda passaram a lhes direcionar severas críticas, repreendendo os dirigentes da "ortodoxia" por não terem esboçado uma reação suficientemente dura no Congresso de Paris no ano de 1900, quando estes se recusaram a expulsar os militantes revisionistas do seio do Partido. Tal fato principiaria o gradual afastamento das duas correntes, culminando no seu definitivo rompimento em 1914, em razão da capitulação das social-democracias européias à política de guerra de seus países.

\section{2- O contra-ataque da ala revolucionária}

A publicação dos artigos de Eduard Bernstein na Neue Zeit, em 1897 e 1898, provocou grande turbulência no interior da social-democracia alemã. Esta encontrava-se, então, sob a ameaça de ser novamente colocada na ilegalidade, devido à submissão de um novo projeto de lei anti-socialista ao Reichstag. Assim, a conclamação revisionista pela renúncia ao objetivo final revolucionário e a defesa de uma tática puramente pacífica, a ser concretizada de forma lenta e gradual por via de reformas, gerou um clima de grande indignação entre as correntes revolucionárias do partido.

Não somente a proposta de revisão teórica das teses marxistas - vista com profunda desconfiança -, mas, sobretudo, a mera conjectura de abdicação da luta de classes e adoção de uma política conciliatória, considerando o estabelecimento de alianças com os mesmos grupos que se empenhavam em mais uma vez relegar os social-democratas à clandestinidade, era concebida como uma traição política e uma capitulação prévia à burguesia.

791 MATTHIAS, Erich. "Kautsky y el kautskismo". In: La revolución social. El camino del poder. Cuadernos de pasado y presente, n. 68. México, D.F: PYP, 1978, p. 30. 
Sem dúvida, uma das primeiras e mais contundentes respostas ao revisionismo partiu de Rosa Luxemburg ${ }^{792}$, em seu ensaio "Reforma social ou Revolução?” (1899). Rosa percebia a vital importância de se refutar os argumentos apresentados por Bernstein, procurando fornecer bases para a fundamentação do socialismo, sem, no entanto desconsiderar as novas condições históricas encontradas. Em carta a Leo Jogiches, de 2 de julho de 1898, a autora expôs as dificuldades enfrentadas para a realização de tal tarefa:

Agora o mais importante - Bernstein. Consegui ter uma idéia boa a respeito do conjunto do artigo, porém nem por isso está melhor, porque vejo enormes dificuldades. Tenho já um plano excelente. Há dois problemas difíceis: 1) escrever sobre a crise; 2) demonstrar de modo inequívoco que o capitalismo fracassará. É indispensável prová-lo, mas isto significa escrever concisamente um novo argumento para o socialismo científico. Ajude-me, pelo amor de Deus, ajude-me. A rapidez é essencial porque 1) se alguém se adianta a nós, perde-se todo o trabalho; 2) porque o acabamento toma muito tempo. Começamos muito bem. As notas que escrevi em Zurique são a massa (contudo só meio assada) de que precisamos - se soubesse o que escrever, a forma aí então se delinearia, sinto-o em meus ossos. Acho-o tão importante, daria metade de minha vida por este artigo. ${ }^{793}$

Tendo finalizado a sua réplica a Bernstein em fins de 1898, a autora ganhou notoriedade dentro do partido por seus vastos conhecimentos de economia e filosofia combinados a uma crítica radical ao oportunismo pequeno-burguês, que pretendia modificar os objetivos do partido no intuito de influir na prática adotada. Para Rosa, o revolucionarismo seria da própria essência do socialismo; sendo assim, o dilema entre reforma social ou revolução corresponderia à questão de "ser ou não ser" da social-democracia. A tentativa revisionista de converter a reforma social, de simples meio da luta de classes em seu fim último esvaeceria a distinção entre o movimento socialista e as demais organizações da democracia burguesa ou do radicalismo burguês.

Prosseguia ainda afirmando que entre a reforma social e a revolução, a socialdemocracia veria um elo indissolúvel: a luta pela reforma social seria o meio e a revolução social o fim ${ }^{794}$. Por conseguinte, na polêmica erigida por Bernstein e seus partidários o que estaria em jogo afinal não seria os métodos de luta ou o emprego de táticas, mas a própria

\footnotetext{
${ }^{792}$ Rosa Luxemburg (1871-1919), de origem judia e polonesa, viu-se obrigada a deixar a Polônia em 1889, onde ajudou a fundar o Partido Social-Democrata Polonês. Doutorou-se em Economia em Zurique, chegando à Alemanha em 1898, no auge dos debates com os revisionistas (Cf. LOUREIRO, Maria Isabel. Rosa Luxemburg: vida e obra. São Paulo: Expressão Popular, 2003).

${ }^{793}$ LUXEBURG, Rosa. Camarada e amante: cartas de Rosa Luxemburg a Leo Jogiches. Rio de Janeiro: Paz e Terra, 1983, p.81.

${ }^{794}$ LUXEMBURG, Rosa. Reforma social ou revolução. São Paulo: Global Editores, 1986, p. 23.
} 
existência do movimento socialista. Rosa, portanto, advertia que a teoria de Bernstein estaria em absoluta contradição com os princípios do socialismo científico:

Se o revisionismo se limitasse à previsão de uma evolução do capitalismo muito mais lenta do que é normal atribuir-lhe, poder-se-ia unicamente inferir um espaçamento da conquista do poder pelo proletariado, o que na prática resultaria simplesmente num abrandamento da luta. Mas não se trata disso. O que Bernstein põe em causa não é a rapidez dessa evolução, mas a evolução do capitalismo em si mesma e, por conseqüência, a passagem ao socialismo ${ }^{795}$.

Quanto à crítica bernsteiniana da teoria do colapso, Rosa opôs-lhe uma minuciosa análise no intuito de demonstrar a possibilidade objetiva do advento de crises gerais, baseando-se em três fundamentos do capitalismo: a crescente anarquia da produção, a socialização crescente do processo produtivo e a organização e consciência de classe. Cabe destacar que apesar de nesta época a autora ainda identificar-se com o "marxismo ortodoxo" apregoado pelos dirigentes do partido, não fazia a defesa do automatismo de tais tendências históricas nem lhes conferia a insígnia de leis naturais ${ }^{796}$.

Ademais, a ênfase atribuída por Rosa à consciência de classe, sem a qual o socialismo não seria possível, afastaria a idéia de um processo histórico predeterminado e fatalista ${ }^{797}$. Neste sentido, somente a interferência consciente, a luta política da classe operária, poderia conduzir à transformação socialista ${ }^{798}$ :

É evidente que a tática social-democrata não consiste em esperar o ponto extremo das contradições capitalistas para que se produza uma mutação revolucionária da situação. Pelo contrário, a essência da tática revolucionária consiste em

\footnotetext{
795 Ibid, p. 28.

${ }^{796}$ Ibid, p. 29.

797 Segundo Isabel Maria Loureiro: "Mesmo em obras de forte caráter economicista como "Reforma Social ou Revolução?”, “A acumulação do capital” e "Anticrítica”, em que insiste na teoria do colapso, Luxemburg repete que o socialismo não resulta automaticamente das contradições objetivas do capitalismo, que é necessário o "conhecimento subjetivo, por parte da classe operária, da inelutabilidade da supressão da economia capitalista por meio de uma revolta (Umwälzung) social". Ou seja, ela compreendeu, desde o início da sua carreira política, que a economia por si só não levará ao socialismo" (LOUREIRO, Isabel Maria. Rosa Luxemburg: os dilemas da ação revolucionária. São Paulo: UNESP, 1995, p. 32-33).

${ }^{798}$ Na brochura Junius, escrita em 1915, Rosa deixa clara a sua perspectiva anti-mecanicista e dialética: "Os homens não fazem sua história de cabo a rabo. Mas a fazem eles mesmos. O proletariado depende em sua ação do grau de desenvolvimento social da época, mas a evolução social não se produz a margem do proletariado; este é seu impulso e sua causa, tanto como seu produto e sua conseqüência. Sua ação forma parte da história contribuindo para determiná-la. (...) A vitória do socialismo não cairá do céu como algo fatal; esta vitória não poderá ser alcançada senão graças a uma larga série de enfrentamentos entre as forças velhas e as novas, choques no decurso dos quais o proletariado internacional realiza sua aprendizagem sob a direção da social-democracia e tenta tomar em suas mãos seu próprio destino, de apoderar-se do timão da vida social. Quem era um joguete passivo da história tenta converter-se em lúcido condutor (LUXEMBURG. La crisis de la socialdemocracia. México: Roca, 1972, p.22).
} 
reconhecer a tendência do desenvolvimento e daí transpor as suas conseqüências últimas para a luta política ${ }^{799}$.

Não obstante, neste ensaio Rosa concebia a revolução socialista como uma necessidade histórica objetiva. Nestes termos, os fenômenos que Bernstein apontara como sinais da "capacidade de adaptação" do capitalismo - as fusões, o crédito, o aperfeiçoamento dos meios de comunicação, a elevação do nível de vida da classe operária - não conseguiriam evitar o desmoronamento do sistema e assegurar sua sobrevivência através da anulação ou atenuação de suas contradições internas ${ }^{800}$.

O crédito - instituição que aumenta a capacidade extensiva da produção e facilita a troca - contribuiria para a concentração de grande número de capitais privados, como, por exemplo, através da ampliação do número de sociedades por ações. Deste modo, incrementaria a capacidade de expansão da produção em proporções inauditas, levando-a a ultrapassar constantemente os limites do mercado. Sendo assim, o crédito seria uma "faca de dois gumes", uma vez que colaboraria para a intensificação das crises de superprodução, e, consequientemente, para a "destruição radical das forças produtivas que por ele foram movimentadas".

Desde os primeiros sintomas de estrangulamento do mercado, o crédito funde-se, abandona a sua função de troca precisamente no momento em que seria indispensável; revela a sua ineficácia e inutilidade quando ainda existe, e contribui, no decurso da crise, para reduzir ao mínimo a capacidade de consumo do mercado $^{801}$.

De "fator de adaptação", o crédito passa a ser entendido como um elemento agravante das contradições e das crises do capitalismo. O mesmo processo verificar-se-ia com as associações patronais, tais como fusões e monopólios, que, ao invés de colocarem fim à anarquia da produção não passariam de paliativos para a baixa fatal da taxa de lucro em certos setores da produção ${ }^{802}$ :

\footnotetext{
${ }^{799}$ Luxemburg, 1986, p.67.

${ }^{800}$ Ibid, p.31.

${ }^{801}$ Ibid, p.34.

802 "No conjunto, as fusões, tal como o crédito, aparecem como fases bem determinadas do desenvolvimento que, em última análise, apenas contribuem para aumentar a anarquia do mundo capitalista, manifestando em si próprias e levando à exaustão todas as contradições internas. Agravam o antagonismo existente entre o modo de produção e o modo de troca, agudizando a luta entre produtores e consumidores (...). Agravam, por outro lado, a contradição entre o modo de produção e o modo de apropriação, opondo à classe operária, da maneira mais brutal, a força superior do capital organizado, conduzindo assim ao extremo o antagonismo entre o capital e o trabalho" (Ibid, p.38).
} 
O objetivo econômico final e a ação das organizações é, excluindo a concorrência no interior de um setor da produção, influenciar a repartição do lucro bruto realizado no mercado, de maneira a aumentar a parte desse setor da indústria à custa de outros, precisamente por estar generalizada. Prolongada a todos os setores industriais importantes, anula por si própria o seu efeito. ${ }^{803}$

Deste modo, os acordos patronais estariam muito longe de suprimir as crises econômicas, resultando antes no agravamento da concorrência no exterior e reforçando, assim, a anarquia no mercado mundial. Rosa analisa, portanto, as consequiências do desenvolvimento do mercado mundial, esgotado pela concorrência dos países capitalistas, que incluiriam a imobilização parcial ou forçada do capital em dimensões consideráveis.

Ao ocupar-se do estudo da nova fase do desenvolvimento do capitalismo, caracterizado pelo agravamento dos antagonismos entre o modo de produção e a troca, o modo de produção e o modo de apropriação e o capital e o trabalho, Rosa dera o primeiro passo para a construção de sua teoria acerca do imperialismo, posteriormente apresentada no livro "A acumulação do capital”, de 1913. Neste destacara a impossibilidade de uma acumulação contínua do capital que garantisse o bem-estar e o progresso econômico ${ }^{804}$, na medida em que o processo de capitalização da mais valia e de acumulação do capital dependeriam do contato com formações sociais pré-capitalistas e do acesso a seus mercados e produtos ${ }^{805}$.

Consoante Rosa, Bernstein teria ainda se equivocado em suas conclusões relativas ao aparente fenômeno de preservação e expansão das classes médias. De modo assaz original, Rosa conferiu um sentido alternativo à idéia de desaparição progressiva das classes médias que diferia da perspectiva comumente difundida entre os "ortodoxos". Ao invés de encarar o crescimento do número de possuidores como uma negação do processo histórico de polarização de classes, ou como mera "paragem", uma "letargia" desse desenvolvimento, Rosa, mediante uma interpretação dialética, compreende-o enquanto parte integrante do desenvolvimento complexo e contraditório do capitalismo.

Logo, o processo de polarização não poderia ser representado por uma linha reta descendente que iria do declínio progressivo à desaparição total, mas sim por uma evolução dialética que oscilaria constantemente de acordo com as contradições inerentes ao sistema

\footnotetext{
${ }^{803}$ Ibid, p.36.

${ }^{804}$ LOUREIRO, Isabel M. “Introdução”. In: A revolução russa. Petrópolis: Vozes, 1991, p.18.

805 "O capitalismo necessita das organizações sociais pré-capitalistas como base do seu desenvolvimento, (mas) opera por assimilação das mesmas condições que são as únicas que podem assegurar a sua própria existência" (LUXEMBURG, R. apud GERAS, N. A actualidade de Rosa Luxemburg. Lisboa: Antídoto, 1978, p. 15).
} 
econômico. Sendo assim, as classes médias capitalistas sofreriam a influência de duas tendências antagônicas, uma ascendente e outra descendente:

A tendência descendente é o crescimento contínuo da escala de produção que ultrapassa periodicamente o quadro dos capitais médios, desviando-os regularmente do campo da concorrência mundial. A tendência ascendente é constituída pela depreciação periódica do capital existente, o que faz baixar por um certo tempo a escala da produção segundo o valor do capital mínimo necessário, tal como a penetração da produção capitalista em novas empresas ${ }^{806}$.

A disputa entre empresas médias e o grande capital não resultaria necessariamente na diminuição absoluta das primeiras, podendo ser constatado ou um aumento progressivo do capital mínimo necessário para o funcionamento das empresas, ou ainda uma diminuição constante do intervalo de tempo durante o qual os pequenos capitalistas detêm a exploração dos setores de produção no qual atuam. Deste modo, nas palavras de Rosa, seria como se "os pequenos capitais fossem periodicamente ceifados para apressar seu florescimento a fim de serem novamente ceifados pela grande indústria" ${ }^{\circ 07}$.

As abundantes estatísticas citadas por Bernstein tendo por escopo comprovar, com base em fundamentos econômicos, a elevação do número de proprietários - e assim desacreditar a teoria da concentração - indicando a emergência de sociedades por ações, seriam, para Rosa mal-interpretadas pelo autor ${ }^{808}$. Na realidade o aumento da quantidade de sociedades por ações teria um significado completamente diverso: assinalaria o crescente processo de socialização da produção no interior do capitalismo, combinado com a concentração do capital. Assim, Rosa assevera:

Hoje uma empresa capitalista não corresponde, como outrora, a um único proprietário do capital, mas a um número cada vez mais considerável de capitalistas e que por conseqüência, a noção econômica do "capitalista" não dissimula um indivíduo isolado, significa que o atual capitalista industrial é uma pessoa coletiva composta por centenas ou mesmo milhares de indivíduos, e que a própria categoria capitalista tornou-se, nos quadros da economia capitalista, uma categoria social, que se socializou. ${ }^{809}$

\footnotetext{
${ }^{806}$ Loureiro, 1991, p. 42.

${ }^{807}$ Ibid, p.42.

${ }^{808}$ Rosa adverte que para ter valor comprobatório, as estatísticas deveriam se reportar aos mesmos setores da indústria, e, então, demonstrar se as pequenas empresas surgem em substituição às grandes empresas, ao invés de em setores onde predomina o capital familiar, o artesanato ou a micro-empresa. De acordo com Rosa, a substituição de inúmeras empresas médias ou pequenas por sociedade por ações só poderia ser explicada pela penetração, em novos setores da produção, do sistema das sociedades por ações (ibid, p.77).

${ }^{809}$ Ibid, p.78.
} 
A socialização crescente da produção consistiria, portanto, na reunião de "um grande número de pequenas fortunas num grande capital de produção", separando-se, por outro lado, a produção da propriedade do capital ${ }^{810}$. Destarte, segundo Rosa, Bernstein teria novamente se equivocado ao entrever no fenômeno das sociedades por ações uma dispersão e não uma concentração do capital - além de conceber o capitalista, não como uma unidade econômica, mas como uma unidade fiscal. Deste modo, graças à "confusão herdada da economia vulgar", "todo o mundo lhe surge como um formigueiro de capitalistas". 811

Por conseguinte, para a autora, a "teoria da adaptação", enunciada por Bernstein, não seria mais do que uma generalização teórica do ponto de vista do capitalista isolado, isto é, uma vertente da economia vulgar burguesa, na qual se toma os fenômenos de forma independente e parcial. Com efeito, seus "antídotos" contra os males do capitalismo seriam igualmente restritos e ineficazes ${ }^{812}$, posto que, em sua visão, "não há nenhuma erva medicinal que cresça no lixo da sociedade capitalista que possa ajudar a curar a anarquia capitalista" ${ }^{\natural 13}$.

Consoante aponta Luxemburg, recorrendo à economia burguesa Bernstein tentou destruir as fundações da teoria marxista do valor - baseada em uma perspectiva histórica - de modo a obscurecer as contradições presentes na economia capitalista. Nestes termos, passa a conceber a economia capitalista como uma realidade perene, erigindo a sociedade burguesa à "última etapa da evolução da humanidade" ${ }^{814}$. Para tanto, ao mesmo tempo em que tentaria transformar a lei do valor-trabalho de Marx em uma "simples abstração", uma "construção do espírito", Bernstein recorreria a construções idealistas a respeito de uma sociedade socialista baseada no princípio do cooperativismo ${ }^{815}$ - cujo objetivo seria a "repartição mais justa" e

\footnotetext{
${ }^{810}$ Ibid, p.77-78.

${ }^{811}$ Ibid, p.78-79.

${ }^{812}$ Ibid, p.71.

${ }^{813}$ LUXEMBURG, R. apud GERAS, N. A actualidade de Rosa Luxemburg. Lisboa: Antídoto, 1978, p. 13.

${ }^{814}$ Ibid, p.84.

${ }^{815}$ De acordo com Rosa, as cooperativas seriam instituições de natureza híbrida dentro do capitalismo, por constituírem uma produção socializada em miniatura que é acompanhada por uma troca capitalista. Na economia capitalista, devido a concorrência, para que a empresa possa sobreviver seria necessária uma "impiedosa exploração da força do trabalho, quer dizer, a dominação completa do processo de produção pelos interesses capitalistas. Praticamente, isso traduz-se numa necessidade de intensificação do trabalho, de encurtar ou prolongar a sua duração conforme a conjuntura, de contatar ou dispensar a força de trabalho conforme as necessidades do mercado, numa palavra, praticar todos os métodos, sobejamente conhecidos, que permitam a uma empresa capitalista sustentar a concorrência de outras empresas" (Ibid, p.87-88). Deste modo seus membros passariam a desempenhar o papel de empresários capitalistas. Assim, "uma reforma socialista baseada no sistema de cooperativas abandona a luta contra o capital da produção (...) e se contenta em dirigir os seus ataques contra o capital comercial, mais exatamente o pequeno e o médio capital comercial. Só ataca os ramos secundários do tronco capitalista" (Ibid, p.89).
} 
cuja legitimação histórica seria a idéia de "justiça" - que surgiria nos interstícios da sociedade burguesa.

A "política de compensação", neste sentido, seria uma "política de mistificação" ${ }^{816}$, uma vez que traduziria uma perspectiva fantasiosa que vincularia a realização "automática" de reformas à transformação gradual da sociedade em uma sociedade socialista. Em resumo, ao negar as contradições internas do sistema capitalista, rejeitando assim a teoria do colapso, Bernstein buscaria embasar o socialismo em um "conhecimento puro", conferindo, desta forma, um fundamento idealista do socialismo. Com efeito, o autor cairia no seguinte dilema: “ou o revisionismo tem razão - e nesse caso a transformação socialista da sociedade é uma utopia - ou o socialismo não é uma utopia e, nesse caso, a teoria dos "fatores de adaptação" perde a sua base" ${ }^{\natural 17}$.

Outrossim, de acordo com Rosa, o desenvolvimento ininterrupto da democracia antevisto pelo revisionismo - à maneira do liberalismo burguês - como uma lei fundamental da história humana, revelar-se-ia uma "miragem", pois o regime político seria sempre o resultado de um conjunto de fatores políticos internos e externos. Ademais, Rosa constata que as instituições democráticas teriam chegado ao fim de sua intervenção no desenvolvimento da sociedade burguesa, após a concretização da unificação dos grandes Estados modernos.

Assim, o liberalismo se tornaria "inútil para a sociedade burguesa, chegando mesmo a entravar o seu desenvolvimento" ${ }^{\text {} 818}$. Diante disso, a autora reprova as tentativas efetuadas por Bernstein de aconselhar o operariado a "recuperar o liberalismo assustado e afastá-lo do redil da reação onde se refugiou" ${ }^{819}$. O abandono do objetivo último do socialismo pela classe operária em nome da "ressurreição da democracia burguesa", significaria tão somente a rendição à ordem capitalista ${ }^{820}$. Com efeito, diferentemente de Bernstein, Rosa aduz que "não é a sorte do movimento socialista que está ligada à democracia burguesa, mas pelo contrário, é a democracia que se encontra ligada ao movimento socialista" ${ }^{~}{ }^{21}$. Deste modo, em lugar de abrirem mão de sua emancipação em nome da democracia, seria indispensável realizá-la para

\footnotetext{
${ }^{816}$ Ibid, p. 65.

${ }^{817}$ Ibid, p. 32

${ }^{818}$ Ibid, p. 95 .

${ }^{819}$ Ibid, p.96.

820 "Fazendo do abandono do socialismo uma condição primeira das premissas sociais da democracia burguesa, demonstra clara e simultaneamente que a democracia contradiz a atual orientação interna da evolução social e que o movimento operário é uma resultante direta dessa orientação” (Ibid, p.96).

${ }^{821}$ Ibid, p. 97 .
} 
que a democracia pudesse avançar. Portanto, nas palavras de Rosa, "renunciar à luta pelo socialismo é renunciar simultaneamente ao movimento operário e à própria democracia” ${ }^{\Perp 22}$.

Segundo Rosa, o empirismo de Bernstein o tornaria incapaz de examinar os fenômenos sob o ponto de vista da totalidade do desenvolvimento econômico e social. Este fato acarretaria a elaboração de uma concepção histórica mecânica e antidialética ${ }^{823}$. À perspectiva totalizante e revolucionária de Marx, Bernstein contraporia uma visão parcial, baseada na análise de fatos empíricos isolados, sem uma conexão entre si $^{824}$. A adoção desta perspectiva poderia explicar vários aspectos de sua teoria, como, por exemplo, a crença na possibilidade de implantação do socialismo por intermédio de reformas legais balizadas pelo Estado. Para Rosa, ainda que assumisse medidas e funções de interesse geral, o Estado não deixaria de ser uma organização da classe capitalista dominante. Desta forma, o Estado somente alinharia-se com o proletariado na medida em que o interesse geral e o desenvolvimento social coincidissem com os interesses da classe dominante" ${ }^{, 825}$.

O atual Estado não é uma "sociedade" no sentido de "classe obreira ascendente", mas o representante da sociedade capitalista, quer dizer, um Estado classista. Eis porque a reforma por ele proposta não constitui aplicação do "controle social", isto é, do controle da sociedade de trabalhadores livres sobre seu próprio trabalho, mas um controle da organização da classe do capital sobre os processos de produção do capital. Aliás, as reformas chocam-se com os limites dos interesses do capital $^{826}$.

Portanto, a evolução linear e gradual em direção ao socialismo, seja por intermédio da atuação parlamentar e sindical, seja pela democratização política do Estado, não poderia concretizar-se, posto que este conservaria seu caráter de classe. Estes elementos, de acordo com Rosa, poderiam, no melhor das hipóteses, manter a exploração capitalista no interior dos limites "normais" determinados em cada momento pela conjuntura, mas estariam longe do processo de suprimir a exploração em si mesma, mesmo que progressivamente ${ }^{827}$.

Os sindicatos, por exemplo, teriam como função principal "permitir aos operários a realização da lei capitalista dos salários", ou seja, "a venda da força de trabalho ao preço

\footnotetext{
${ }^{822}$ Ibid, p.97.

${ }^{823}$ Cf. LOUREIRO, Isabel Maria. Rosa Luxemburg: os dilemas da ação revolucionária. São Paulo: UNESP, 1995, p. 25.

${ }^{824}$ Luxemburg, 1986, p. 27.

${ }^{825}$ Ibid, p. 56.

${ }^{826}$ Ibid, p.50.

${ }^{827}$ Ibid, p.46.
} 
conjuntural do mercado" 828 . Neste sentido, os sindicatos serviriam aos interesses do proletariado tendo em vista as conjunturas do mercado. Por esta razão, não poderiam suprimir a lei dos salários nem exercer uma "influência reguladora progressiva na produção" em prol do interesse geral do proletariado:

A atividade dos sindicatos reduz-se, essencialmente, à luta para o aumento dos salários e para a redução do tempo de trabalho, procura unicamente ter uma influência reguladora sobre a exploração capitalista, segundo as flutuações do mercado; toda a intervenção no processo de produção é-lhe, pela própria natureza das coisas, interdita ${ }^{829}$.

Por conseguinte, de acordo com Rosa, "mesmo no interior dos limites de sua esfera de influência, o movimento sindical não aumenta indefinidamente a sua expansão, como o supunha a teoria da adaptação ao capitalismo" ${ }^{\Perp 830}$, ao contrário, ele tenderia a encontrar pela frente cada vez mais dificuldades, representadas pelos limites impostos pelos interesses do capital $^{831}$. Deste modo, a idéia de uma expansão ilimitada do sindicalismo não passaria de uma ilusão.

Em seu discurso ao Congresso de Hannover, de 1899, Rosa voltou a questionar a idéia de uma evolução linear e mecânica da sociedade em direção ao "socialismo", destacando sua incapacidade para promover a emancipação econômica e política do proletariado:

Camaradas que pensam que podem conduzir a sociedade para o socialismo de modo pacífico, sem um cataclismo, não possuem base histórica nos fatos. Por revolução nós não precisamos dizer banho de sangue. Uma revolução também pode ser efetivada num nível cultural, e se algum momento houvesse a possibilidade disto seria numa revolução proletária, já que somos os últimos a aderir a meios violentos, os últimos a desejar uma revolução brutal sobre nós. Mas esta questão não depende de nós, depende de nossos oponentes. Nós devemos colocar de lado a questão da forma pela qual nós tomaremos o poder, pois não podemos prever tais condições. Nós estamos interessados na essência do processo, que é a nossa luta pela total transformação da ordem econômica capitalista vigente, que pode ser obtida apenas pela conquista do poder do Estado e nunca pelo caminho da reforma social dentro dos limites da sociedade existente. Estes que cedem a esta esperança baseiam-

\footnotetext{
${ }^{828}$ Ibid.

${ }^{829}$ Ibid, p.48.

${ }^{830}$ Ibid.

${ }^{831}$ Segundo Rosa, "quando o desenvolvimento da indústria atingir seu apogeu e o mercado mundial iniciar a fase descendente, a luta sindical tornar-se-á mais difícil: $1^{\circ}$ - porque as conjunturas objetivas do mercado serão desfavoráveis à força de trabalho, a procura da força de trabalho aumentará mais lentamente e a oferta mais rapidamente o que não é o caso atual; $2^{\circ}$ - porque o próprio capital para se compensar das perdas sofridas no mercado mundial, se esforçará por reduzir a parte do produto pertencente aos operários” (Ibid, p.49).
} 
se ou na ignorância em relação ao passado ou no otimismo em relação ao futuro ${ }^{832}$.

A perspectiva revolucionária de Rosa Luxemburg colocava-a em conflito não somente com o grupo revisionista, mas também com a direção do partido, adepta de uma tática exclusivamente parlamentar. Já em seu ensaio, Rosa punha em xeque a confiança cega na "via democrática", dispondo que o caráter contraditório do Estado capitalista manifestar-se-ia "de forma explosiva" no parlamentarismo moderno. Segundo a autora, "é evidente que formalmente o parlamentarismo serve para exprimir na organização do Estado os interesses do conjunto da sociedade"; "mas, por outro lado, o que o parlamentarismo representa aqui é unicamente a sociedade capitalista, quer dizer, uma sociedade onde predominam os interesses capitalistas". Por conseqüência, continua Rosa, "nessa sociedade, as instituições formalmente democráticas reduzem-se, no seu conteúdo, a instrumentos dos interesses da classe dominante" ${ }^{, 833}$.

Também a idéia da conquista por uma maioria parlamentar aparece como um cálculo errado: preocupando-se unicamente, à semelhança do liberalismo burguês, com o aspecto formal da democracia, descuida-se totalmente do outro aspecto, o do seu conteúdo real $^{834}$.

Para Rosa, portanto, o Estado tenderia a assumir mais abertamente seus interesses de classe, uma vez que a propriedade privada ganharia a forma de uma exploração capitalista cada vez mais brutal. As contradições internas do capitalismo se acentuariam - assim como a conscientização da classe operária - abrindo caminho para a realização de um golpe revolucionário ${ }^{835}$. Contrariamente à Bernstein, Rosa concebia as crises como sendo manifestações orgânicas, inseparáveis do conjunto da economia capitalista ${ }^{836}$, que corrigiriam periodicamente o desequilíbrio existente entre a capacidade ilimitada de expansão da produção e os limites estreitos do mercado:

[A] concepção mecânica e antidialética manifesta-se na idéia de Bernstein de que a cessação das crises é um sintoma "da adaptação" da economia capitalista. Para ele as crises reduzem-

\footnotetext{
${ }^{832}$ Discurso de Rosa Luxemburg de 11/10/1899, no Congresso de Hannover (<www.marxists.org $>$ ).

${ }^{833}$ Luxemburg, 1986, p.59.

${ }^{834}$ Ibid, p.60.

835 “As relações de produção da sociedade capitalista aproximam-se sucessivamente das relações de produção socialista. Em contrapartida, as suas relações políticas constroem entre sociedade capitalista e a sociedade socialista um muro cada vez mais alto. Nesse muro, nem as reformas sociais nem a democracia abrirão brechas, contribuirão, pelo contrário, para o segurar e consolidar. Apenas um golpe revolucionário, isto é, a conquista do poder político pelo proletariado, o poderá abater" (Ibid, p.61).

${ }^{836}$ Ibid, p. 69.
} 
se a desordens produzidas no mecanismo da economia; se as desordens param o mecanismo, recomeça o movimento. Ora, de fato, as crises não são desordens no sentido exato da palavra, ou melhor, são desordens mas sem as quais a economia capitalista não poderia desenvolver ${ }^{837}$.

Embora entre os social-democratas e os revisionistas não houvesse divergências em termos práticos, a luta cotidiana endossada pelo partido possuiria um sentido diferente. Tanto a luta sindical como a luta parlamentar seriam encaradas, na visão de Rosa, como meios de dirigir e educar, pouco a pouco, o proletariado para a conquista do poder político, e não apenas com vistas a aquisição de melhorias pontuais imediatas.

Deste modo, tais lutas revestir-se-iam de um significado socialista, pelo fato de consistirem em uma preparação para o processo de transformação revolucionária, do qual tomará parte o proletariado. Através da experiência da luta sindical e política, o proletariado adquiriria a convicção de que é impossível transformar radicalmente a sua situação por meio de uma única luta, e, assim, sentir-se-ia motivado a apoderar-se do poder político, constituindo o fator subjetivo da transformação socialista ${ }^{838}$. Por atuar sobre a consciência do proletariado, organizando-o como classe, o objetivo revolucionário não poderia ser descartado sem, com isso, abandonar-se a própria perspectiva de classe. Portanto, a desvinculação entre as reformas sociais e a revolução tornaria esta última irrealizável, além de enfraquecer simultaneamente a coesão do movimento e a busca pelos objetivos traçados a curto prazo ${ }^{839}$.

Em síntese, o abandono do objetivo último - a revolução - em prol das reformas sociais, vistas como objetivos autônomos, conduziria à perda do caráter de classe do partido, incutindo uma mentalidade pequeno-burguesa, ou mesmo burguesa, no proletariado. Sob este aspecto, a definição do objetivo final não seria uma questão meramente acadêmica, sem relação imediata com a prática, na medida em que constitui o caráter socialista de todo o movimento. Sendo assim, para um "partido proletário revolucionário, não existe questão mais prática do que a referente ao objetivo final" 840 .

\footnotetext{
${ }^{837}$ Ibid, p.69.

${ }^{838}$ Ibid, p.64.

839 "Qualquer que seja a tática utilizada, e porque as reformas sociais são e continuarão a ser, no regime capitalista, nozes ocas, a etapa seguinte será, muito logicamente, a desilusão, mesmo no concernente ao valor próprio das reformas (...)" (Ibid, p.66).

${ }^{840}$ Discurso de Rosa ao Congresso de Stuttgart, de 3/10/1898 (www.marxists.org). Rosa complementa: "por objetivo final não se quer dizer a imagem de um Estado futuro, mas o pré-requisito para qualquer sociedade futura, a conquista do poder político.(...) Esta concepção de nossa tarefa está intimamente relacionada com a nossa concepção da sociedade capitalista: imersa em insolúveis contradições que vão requerer ulteriormente uma explosão, um colapso".
} 
Tendo isso em vista, Rosa conclui que a "reforma e a revolução não são métodos diferentes do progresso histórico que se possam escolher à vontade", "mas fatores diferentes da evolução da sociedade classista, que se condicionam e completam reciprocamente" ${ }^{\prime 41}$. Enquanto a revolução seria um ato de criação política, a legislação seria uma expressão, no plano político, da existência "vegetativa e contínua" da sociedade. Assim, as reformas estariam subordinadas à direção histórica - ou forma social - conferida pela última revolução. Seria, portanto, errôneo apresentar - como faz Bernstein - "o trabalho de reformas como uma revolução diluída no tempo, e a revolução como uma reforma condensada":

Uma revolução social e uma reforma legal não são elementos que se distingam pela sua duração, mas pelo seu conteúdo; todo o segredo das revoluções históricas, da conquista do poder político reside precisamente na passagem de simples modificações quantitativas, numa nova qualidade ou, concretizando, na passagem de uma dada forma de sociedade a outra num período histórico. ${ }^{842}$

A escolha pela via das reformas legais em detrimento da conquista do poder político, isto é, da revolução social, implicaria na escolha de um diferente objetivo: ao invés de almejar a edificação de uma nova sociedade, contentar-se-ia com a introdução de modificações parciais à sociedade existente ${ }^{843}$. Destarte, seria impossível transformar as relações fundamentais da sociedade capitalista através de reformas legais que necessariamente respeitariam o alicerce institucional burguês ${ }^{844}$.

Sob o pretexto de que a conquista do poder pelo proletariado não deveria ser realizada prematuramente, Bernstein condenaria o movimento operário à inação, culminando na "traição passiva de sua própria causa" ${ }^{845}$. Para Rosa, ao contrário, a grande massa popular consciente somente poderia realizar a revolução prematuramente, uma vez que ela seria parte de um processo de amadurecimento do próprio proletariado, que travaria uma longa e intensa batalha até a sua concretização definitiva. Destarte, opõe-se à concepção de que a revolução proletária não deveria chegar demasiado cedo por não encontrar "maduros" nem as condições econômicas nem o proletariado. A seu ver, a revolução nunca chegaria demasiadamente cedo

\footnotetext{
${ }^{841}$ Ibid, p. 100 .

${ }^{842}$ Ibid, p. 101.

843 "Marx e Engels nunca puseram em dúvida a necessidade da conquista do poder político pelo proletariado. Estava reservado a Bernstein considerar o pântano do parlamentarismo burguês como o instrumento chamado a realizar a transformação social mais formidável da história, quer dizer, a transformação das estruturas capitalistas em estruturas socialistas" (Ibid., p.106).

${ }^{844}$ Ibid, p. 103.

${ }^{845}$ Ibid.
} 
posto que a simples existência das forças revolucionárias do proletariado já indicariam a maturidade das condições econômicas e o avanço produzido pela experiência da ação revolucionária.

Cabe lembrar, portanto, que embora Rosa acreditasse ser a democracia burguesa um importante instrumento para a organização da classe operária - por criar formas políticas que serviriam ao proletariado como "trampolim e sustentáculo na sua luta pela transformação revolucionária da sociedade burguesa" e possibilitar que, ao lutar pela democracia e exercer os seus direitos, o proletariado ganhe a consciência dos seus interesses de classe e de suas tarefas históricas -, ela de modo algum tornaria inútil ou desnecessária a conquista do poder político $^{846}$.

Como foi visto, Rosa, à frente do grupo revolucionário - que passaria a distanciar-se do centro partidário a partir da grande divergência suscitada pela Revolução Russa de 1905 -, condenou enfaticamente as teses expostas por Bernstein. A seu ver estas traduziriam a "primeira e última" tentativa de legitimar cientificamente o oportunismo prático, fenômeno este visto por Rosa como inevitável, fruto das condições da luta e da expansão do movimento social-democrata.

A teoria de Bernstein foi a primeira e a última tentativa para fornecer ao oportunismo uma base teórica. Dizemos "última" porque com a doutrina de Bernstein, o oportunismo foi tão longe - negativamente na abjuração do socialismo científico e positivamente na confusão teórica, amálgama incoerente de todos os elementos disponíveis nos outros sistemas - que nada fica para lhe acrescentar. O livro de Bernstein marca o fim da evolução teórica do oportunismo, extraindo-lhe as últimas conseqüências $^{847}$.

Rosa procurou compreender o revisionismo como fenômeno histórico produzido no decorrer da evolução do partido $^{848}$, sendo resultado da luta permanente contra a ordem estabelecida. Como nos elucidara Rosa,

se se considerar a enorme expansão do movimento no decurso dos últimos anos e o caráter complexo das condições em que se deve travar a luta, assim como os objetivos que deve ter, era inevitável que num determinado momento se manifestasse uma

\footnotetext{
${ }^{846}$ Ibid, p. 105.

${ }^{847}$ Luxemburg, 1986, p.120.

848 “o movimento proletário, mesmo na Alemanha, não se fez de repente socialista, faz-se um pouco em cada dia, faz-se corrigindo os desvios opostos: o anarquismo e o oportunismo; um ou outro erro são fases do movimento considerado como um processus contínuo. Nessa perspectiva não é a aparição de uma corrente oportunista que deve surpreender, é sobretudo a sua fragilidade. Tanto quanto se manifestou em ocasiões isoladas, a propósito da ação prática do partido, poder-se-ia imaginar que se apoiava numa base teórica séria” (Ibid, p.122).
} 
certa flutuação: ceticismo quanto à possibilidade de atingir os grandes objetivos finais, hesitações quanto ao elemento teórico do movimento. O movimento operário não pode e não deve progredir de outra forma; os instantes de hesitação, de descrença, estão muito longe de surpreender os marxistas, pelo contrário, foram previstos e preditos desde há muito por $\operatorname{Marx}^{849}$.

Conforme exposto em seu artigo "Questões de organização da social-democracia russa" $^{\natural 50}$, escrito em 1904, Rosa acreditava ser impossível manter o oportunismo afastado do movimento operário. Ao contrário de Lênin, que responsabilizava a incorporação de elementos estranhos ao operariado nas organizações proletárias pelo oportunismo ${ }^{851}$, a autora via o afluxo em massa de elementos dispersos da sociedade como uma consequiência da progressiva dissolução da sociedade burguesa, ou seja parte do desenvolvimento histórico ${ }^{852}$.

A solução para a questão revisionista residiria na habilidade do partido em "assimilar e digerir" tais elementos. Para tanto, seria necessário que a social-democracia subordinasse-os ao objetivo final da classe operária, dissolvendo o "espírito não-proletário de oposição à ação proletária revolucionária” ${ }^{\circledR 53}$. Esta assimilação, por sua vez, dependeria de um núcleo socialdemocrata proletário forte e educado que arrastasse consigo "seguidores desclassificados e pequeno-burgueses" mediante a aplicação mais rigorosa da disciplina partidária.

Embora o estatuto do partido possa servir de auxílio na luta contra o oportunismo, ele não deveria ser visto como uma arma capaz de substituir a necessária e decisiva influência exercida pela maioria proletária revolucionária dentro do partido. Nestes termos, seria uma ilusão pensar que dispositivos estatutários possam assegurar de antemão a defesa total contra desvios oportunistas e salvaguardar a tática revolucionária.

\footnotetext{
${ }^{849}$ Ibid, p. 121.

${ }^{850}$ LUXEMBURG, R. A revolução russa. Petrópolis: Vozes, 1991.

851 "É perfeitamente natural que a mentalidade pequeno-burguesa irrompa repetidamente nas fileiras dos grandes partidos operários. É perfeitamente natural que isso suceda, e assim sucederá sempre, chegando às próprias peripécias da revolução proletária, pois seria um profundo erro pensar que é necessário que a maioria da população se proletarize "por completo" para que essa revolução seja realizável. (...) A luta ideológica do marxismo revolucionário contra o revisionismo, no final do século XIX, não é mais que o prelúdio dos grandes combates revolucionários do proletariado, que, apesar de todas as vacilações e debilidades dos elementos pequeno-burgueses, avança para o triunfo completo da sua causa" (LÊNIN. "Marxismo e revisionismo". In: Obras escolhidas. $3^{\text {a }}$ ed. São Paulo: Alfa-Omega, v. 1, 1986, p.46).

852 "O afluxo em massa de elementos não proletários para a social-democracia é resultado de causas sociais profundamente enraizadas, tais como o rápido colapso econômico da pequena burguesia, o colapso ainda mais rápido do liberalismo burguês e o deperecimento da democracia burguesa. Portanto, não passa de ilusão ingênua imaginar que esta onda tempestuosa poderia ser contida por tal ou qual formulação dos parágrafos do estatuto do partido." (Luxemburg, 1991, p.56).

${ }^{853}$ Ibid, p.57.
} 
Para Rosa, conquanto a doutrina marxista forneça subsídios para superar os erros oportunistas, constituindo "uma arma devastadora contra todos os tipos fundamentais de pensamento oportunista", este fenômeno seria produto do próprio desenvolvimento histórico do movimento operário, sendo o resultado do "inevitável tatear e experimentar da tática, da necessidade de sintonizar a luta presente, em todas as suas peculiaridades, com os princípios socialistas" ${ }^{854}$. Assim, o oportunismo faria parte da essência da própria luta social-democrata, refletindo suas contradições internas:

O avanço histórico-mundial do proletariado até a vitória consiste num processo cuja particularidade reside no fato de que aqui, pela primeira vez na história, as próprias massas populares, contra todas as classes dominantes, impõem sua vontade. Porém, esta vontade só pode ser realizada fora e além da atual sociedade. Mas, por outro lado, as massas só podem formar essa vontade na luta quotidiana com a ordem estabelecida, portanto dentro dos seus limites. A unificação da grande massa do povo com um objetivo que vai além de toda a ordem estabelecida, da luta quotidiana com a transformação revolucionária, nisto consiste a contradição dialética do movimento social-democrático (grifo nosso), o qual, conseqüente com o processo de desenvolvimento total, precisa avançar entre dois escolhos: entre a perda do seu caráter de massa e o abandono do objetivo final, entre a recaída no estado de seita e a queda no movimento de reformas burguês ${ }^{855}$.

Enquanto expressão teórica do fortalecimento das correntes oportunistas dentro do partido, o revisionismo pretenderia minar do programa partidário todos os aspectos da teoria que representassem um entrave ao livre jogo das barganhas políticas, de modo que pudesse mudar sua tática ao sabor das circunstâncias mais imediatas. Por consequiência, Bernstein abandonaria as categorias do pensamento do proletariado revolucionário - a dialética, a concepção materialista da história, etc. - recaindo em princípios oriundos da ciência, da moral e da democracia burguesas.

Como Rosa nos mostra, os ataques bernsteinianos miraram de forma certeira o centro nervoso da luta revolucionária. Através da rejeição da dialética, a pedra de toque de toda a concepção histórica marxista, permitia-se a acomodação à sociedade existente, a perpetuação da relação de forças sociais e a negação das contradições inerentes aos fenômenos sociais, fechando-se as portas, assim, às possibilidades de transformação pela ação proletária consciente e revolucionária.

\footnotetext{
${ }^{854}$ Ibid.

${ }^{855}$ Ibid, p.58.
} 
Reservando os ataques mais violentos contra a dialética, não estará a visar o modo de pensar específico do proletariado consciente, lutando pelas suas aspirações? Não será a dialética o instrumento que deve ajudar o proletariado a sair das travas onde mergulha o seu futuro histórico, a arma intelectual que permite ao proletariado, ainda sob o jugo material da burguesia, triunfar, convencê-la de que está condenada a morrer, a provarlhe a certeza infalível da sua vitória? Esta arma não terá desempenhado a sua obrigação no âmbito do espírito da revolução? Bernstein, abandonando a dialética, entrega-se ao jogo intelectual menor das fórmulas equilibristas tais como "sim, mas", "por um lado, por outro lado", "ainda que, contudo", "mais ou menos", adota logicamente o modo de pensar histórico da burguesia decadente, modo de pensar que reflete fielmente a sua existência social e a sua ação política ${ }^{856}$.

Por conseguinte, Rosa frisou inúmeras vezes, seja em artigos ou em seus discursos, a necessidade de se refrear a corrente oportunista - "hostil à teoria" e aos princípios socialistas - dentro do partido, o que significaria na prática a expulsão de seus adeptos. Contudo, seus apelos não foram atendidos pelos dirigentes do SPD, que embora recriminassem as teses de Bernstein oficialmente - principalmente nos Congressos de Stuttgart (1898), Hannover (1899), Dresden (1903) e no Congresso da Internacional de Amsterdã (1904) - não consideravam que pudessem representar uma séria ameaça à organização, uma vez que seus desvios teóricos não incidiam na prática já adotada.

Demonstrando preocupações com o descarte dos princípios socialistas, tanto pela direita quanto pelo centro partidário, Rosa concentrou-se em explorar a forma como a teoria marxista havia sido interpretada e apropriada dentro do movimento. Em artigo publicado pelo Vorwärts, em 14 de março de $1903^{857}$, Rosa analisou as razões pelas quais a teoria de Marx e Engels havia passado por um processo de vulgarização e enrijecimento. A autora concluiu que a herança de Marx continuava não-aproveitada pelos chefes ideológicos da social-democracia. Segundo Rosa, se nada fora acrescentado ao edifício construído por Marx não seria pelo fato de o quadro ser rígido demais, nem porque estivesse completamente acabado ${ }^{858}$, mas porque as condições históricas ainda não teriam colocado na ordem do dia questões que Marx havia trabalhado em sua teoria ${ }^{859}$.

\footnotetext{
${ }^{856}$ Luxemburg, 1986, p.115.

${ }^{857}$ Cf. LUXEMBURG, R. "Estacionamentos e progressos do marxismo". In: In: Marxismo. São Paulo: Unitas, [198-], p.179-189.

858 Ibid, 181.

859 "Essa obra que constitui, como descoberta científica, um todo gigantesco, já ultrapassa as necessidades diretas da luta de classe do proletariado, para as quais foi criada. Na análise completa e detalhada da economia capitalista, como no método de pesquisas históricas, com as suas infinitas possibilidades de aplicação, Marx nos
} 
Se sentimos, agora, em nosso movimento, um certo estacionamento das pesquisas teóricas, não é porque a teoria de Marx, de que somos discípulos, não possa desenvolver-se, nem porque tenha "envelhecido", e sim porque nos apoderamos, para a nossa luta, de todas as armas intelectuais mais importantes do arsenal marxista de que tínhamos necessidade até aqui. E nem por isso está esse arsenal esgotado. Não "ultrapassamos" Marx no decurso de nossa luta prática; ao contrário, Marx, com suas criações científicas, é que nos ultrapassou como partido de combate. Marx não só produziu o bastante para as nossas necessidades, como também as nossas necessidades ainda não foram suficientemente grandes para que utilizássemos todas as suas idéias ${ }^{860}$.

Deste modo, Rosa relaciona a falta de forças intelectuais pertencentes ao movimento capazes de continuar a teoria de Marx com as condições históricas encontradas - que fixariam limites bastante estreitos para a atividade intelectual da classe operária ${ }^{861}$ - tendo em vista que "cada época forja, por si mesma, o seu material humano, e se a nossa tivesse verdadeiramente necessidade de trabalhos teóricos, criaria sozinha as forças necessárias à sua satisfação" 862 .

Ao chamar atenção para a necessidade de desenvolver e atualizar a teoria de Marx, Rosa deixa claro que suas críticas a Bernstein não decorrem de uma aversão a uma visão crítica das obras de Marx ou de sua conversão em dogmas sagrados. A reprovação ao revisionismo incide, portanto, sobre as conclusões e conseqüências práticas extraídas desta teoria, que conduziriam ao abandono da meta revolucionária e à rejeição ao método de pesquisa histórica.

Para Rosa, "a parte mais preciosa dos escritos de Marx" seria a concepção materialista e dialética da história. Esta nada mais seria do que "um método de pesquisa, um grupo de idéias gerais, que permitem a visão de um mundo novo, que abrem perspectivas infinitas às

deu muito mais do que era necessário para a prática da luta de classe. Só recorremos ao grande depósito de idéias de Marx, para trabalhar e valorizar alguma parcela de sua doutrina, na medida em que o nosso movimento progride de estágio e se vê em face de novas questões práticas. O nosso movimento, porém, como toda luta verdadeira, se contenta com as velhas idéias diretrizes, ainda muito tempo depois delas terem perdido o valor. Por outro lado, a utilização teórica das lições de Marx não progride senão com extrema lentidão" (Ibid, p.188).

${ }^{860}$ Ibid, p. 188-189.

861 “A classe operária só poderá criar uma arte e uma ciência próprias depois de se libertar completamente de sua atual situação de classe. Tudo o que pode fazer hoje é proteger a cultura da burguesia contra o vandalismo da reação burguesa e criar as condições sociais necessárias ao livre desenvolvimento da cultura. Na sociedade atual, só pode fazer obra positiva nesse domínio, forjando as armas intelectuais necessárias à sua luta emancipadora" (Ibid, p.187).

${ }^{862}$ Ibid, p. 182. 
iniciativas individuais, que dão asas ao espírito para as incursões mais audaciosas nos domínios inexplorados" ${ }^{\prime 863}$.

Já no início da década de 1920, Georg Lukács, em "História e Consciência de Classe" (1923), reconheceu a importância da contribuição de Rosa Luxemburg no combate ao oportunismo e ao marxismo vulgar, destacando igualmente sua ênfase no método como o elemento diferencial em relação a outros marxismos do período ${ }^{864}$. Para o “jovem” Lukács, Rosa Luxemburg teria sido "o único discípulo de Marx que prosseguiu realmente a obra da sua vida, tanto no plano dos fatos econômicos, como no plano do método econômico e que, deste ponto de vista, se ligou concretamente ao nível presente da evolução social” ${ }^{, 865}$.

Lukács ressaltara que a conservação da essência revolucionária do método formaria o ponto de vista do legítimo "marxismo ortodoxo". Neste sentido, não seria necessário se agarrar ao conteúdo doutrinário das obras de Marx, mas apenas zelar pela aplicação correta do método dialético:

Um marxista ortodoxo sério poderia reconhecer
incondicionalmente todos estes novos resultados, rejeitar todas
as teses isoladas de Marx, sem, por um só momento, se ver
forçado a renunciar à sua ortodoxia marxista. O marxismo
ortodoxo não significa, pois, uma adesão sem crítica aos
resultados da pesquisa de Marx, não significa uma fé numa ou
noutra tese, nem a exegese de um livro sagrado. A ortodoxia em
matéria de marxismo refere-se, pelo contrário, e
exclusivamente, ao método $^{866}$.

Assim, segundo Lukács, o método dialético constituiria um método correto para a compreensão adequada das condições históricas passadas e presentes. A dialética, como centro vital do método, permitiria constantemente relacionar o instante presente e as tarefas em relação ao processo histórico, permitindo a unidade entre teoria e prática, considerando-se a relação dialética entre sujeito e objeto no processo histórico.

O que surgiu com o materialismo histórico foi, ao mesmo tempo, a doutrina das "condições da libertação do proletariado" e a doutrina da realidade do processo total de desenvolvimento

\footnotetext{
${ }^{863}$ Segundo Rosa, os "chefes ideológicos" do proletariado estariam deixando "enferrujar essa arma maravilhosa" (Ibid, p.181).

${ }^{864}$ Para Lukács o autêntico "marxismo ortodoxo" , que tem Rosa Luxemburg como principal expoente, diferiria radicalmente do marxismo propagado pelos dirigentes da Segunda Internacional. Cf. LUKÁCS. História e consciência de classe. Rio de Janeiro: Elfos, 1989.

${ }^{865}$ Ibid, p.7. Convém ressaltar que Lukács paulatinamente aproximou-se do leninismo, tendo passado a afirmar que o "renascimento do marxismo" manifestou-se através de duas obras fundamentais: "A acumulação do capital" (1913) - de Rosa Luxemburg - e "Estado e a Revolução" (1917) - de Lênin; por retomarem o modo de exposição histórico e dialético de Marx (Ibid, p.49).

${ }^{866}$ Ibid, p. 15.
} 
histórico, e isto unicamente porque é, para o proletariado, uma necessidade vital, uma questão de vida ou morte, atingir a visão mais perfeitamente clara da sua situação de classe; porque a sua situação de classe só no conhecimento da sociedade total é compreensível; porque os seus atos têm este conhecimento como condição prévia, inelutável. A unidade da teoria e da práxis é pois, apenas a outra face da situação social e histórica do proletariado; do ponto de vista do proletariado, conhecimento de si mesmo e conhecimento da totalidade coincidem, ele é ao mesmo tempo sujeito e objeto do seu próprio conhecimento. ${ }^{867}$

Neste sentido, a primazia do método possibilitaria não somente a interpretação das transformações em processo e das forças recíprocas atuantes, mas a ação dos sujeitos históricos, que assumiriam o ponto de vista da totalidade, isto é, a percepção do caráter fetichista das formas econômicas, da reificação das relações humanas, do caráter histórico e transitório dos fatos e do caráter antagônico da ordem capitalista. Desta maneira, o método dialético - em si, produto da luta de classes - é visto como veículo da revolução. Tal ênfase na atividade crítica e prática afastaria, assim, as concepções fatalistas e voluntaristas.

Para Lukács, "a ruptura revisionista do movimento e da finalidade última", consistiria em um "recuo até o nível mais primitivo do movimento operário" ${ }^{868}$, no isolamento em relação à própria classe, pois "ao separar o que é indivisível, os oportunistas privaram-se desse conhecimento ativo de si, do proletariado" ${ }^{\text {"699 }}$. De forma irônica Lukács afirmara que Bernstein teria exprimido "com a maior clareza" e formulado "com a melhor precisão" a objeção ao método dialético, por não ser perturbado por nenhum conhecimento filosófico:

as consequiências reais, políticas e econômicas que ele deduz do seu desejo de libertar o método das "ratoeiras dialéticas" do hegelianismo, mostram claramente até onde este caminho nos leva. Mostram precisamente que há que separar a dialética do método do materialismo histórico quando se quiser fundar uma teoria conseqüente do oportunismo, da "evolução" sem revolução, da "passagem natural" e sem luta ao socialismo ${ }^{870}$.

Deste modo, ao render-se a um "empirismo tacanho", Bernstein demonstraria sua "repugnância instintiva e profunda por toda a teoria". Por conseguinte, "crê poder encontrar em cada dado, em cada número estatístico, em cada factum brutum da vida econômica, um fato importante para ele". Portanto, "não vê que a mais simples enumeração de fatos, a

\footnotetext{
${ }^{867}$ Ibid, p. 35 .

${ }^{868}$ Ibid, p. 38 .

${ }^{869}$ Ibid, p.57.

${ }^{870}$ Ibid, p. 19 .
} 
justaposição mais despida de comentários é já uma interpretação, que a este nível os fatos foram captados a partir de uma teoria, de um método, que os abstraímos do contexto da vida em que originariamente se encontravam e os introduzimos no contexto de uma teoria" ${ }^{\text {871. }}$.

Como foi visto, o esforço empreendido por Rosa na defesa dos princípios socialistas, isto é da união entre teoria e prática revolucionárias, foi merecidamente destacado por Georg Lukács. Em prefácio à "Greve de massas, partido e sindicatos”, escrito em 1921, Lukács sublinhara o relevante papel desempenhado por Rosa como a "verdadeira líder da revolução proletária" que "cultiva com maior profundidade o marxismo, a dialética revolucionária, a ciência da luta de classes" $" 872$.

Rosa Luxemburg nunca esqueceu a prática e a colocou junto à teoria. A teoria mais profunda e verdadeira só era válida para ela à medida que mostrasse uma nova via para a ação proletária, assim como a crítica foi para ela apenas um meio para a descoberta de meios de luta positivos ${ }^{873}$.

Tal como Rosa havia feito, Lukács procurou extrair o verdadeiro sentido do marxismo: "a revolucionarização do proletariado". Rosa teria sido a primeira a opor a teoria da revolução proletária contra a teoria do oportunismo, retornando ao verdadeiro método de Marx em suas análises a respeito da acumulação do capital e da nova etapa do desenvolvimento capitalista. Assim, Rosa buscava compreender os problemas dos novos tempos como forma de reorientar a práxis revolucionária.

Não obstante todo seu empenho, os "oportunistas" ganharam enorme espaço dentro da social-democracia, privilegiando "seus interesses mesquinhos e míopes" e "viciando as reflexões e os sentimentos do proletariado durante décadas":

habituaram-nos a não observar os acontecimentos do ponto de vista dos interesses de classe gerais do proletariado, mas a fazer que cada um se preocupe antes de tudo com seus interesses pessoais, ou seja, os referidos à profissão ou à fábrica, estritamente. Ao fazê-lo, conseguiram obscurecer a consciência do proletariado, dirigir a classe trabalhadora numa direção oportunista e pequeno-burguesa, além de educá-la neste sentido ${ }^{874}$.

\footnotetext{
${ }^{871}$ Ibid, p. 19-20.

${ }^{872}$ LUKÁCS, G. "Prefácio à "Greves, partido e sindicatos”. In: LÖWY, Michael. A evolução política de Lukács (1909-1929). São Paulo: Cortez, 1998, p.320.

${ }^{873}$ Ibid, p.324.

${ }^{874}$ Ibid, 320-321.
} 
Contudo, como Rosa avaliara, o revisionismo bernsteiniano não conseguiu corresponder a todas as suas pretensões e expectativas ${ }^{875}$. Não somente faltava-lhe a genialidade teórica de uma figura como a de Marx, mas, principalmente, devido ao fato de que as condições históricas ainda colocavam os princípios revolucionários e a crítica à sociedade burguesa na ordem do dia. Isto restou evidenciado em um curto espaço de tempo, iniciado a partir da sublevação operária na Rússia, em 1905, da adesão do partido à guerra imperialista em 1914, da Revolução Bolchevique em 1917 e da Revolução e contra-revolução (levada a cabo pela corrente direitista do SPD) na Alemanha em 1918 e 1919, que culminou no assassinato de Rosa Luxemburg e Karl Liebknecht. A cada novo desdobramento histórico restavam manifestas as profundas divergências ideológicas e os inúmeros conflitos que abatiam os social-democratas, alquebrando sua frágil e dissimulada unidade. Como expressara Rosa em discurso no Congresso de Fundação da Liga Spartakus, em 31 de dezembro de 1918:

a dialética da história quis que retomássemos agora as concepções que Marx e Engels tinham depois abandonado (...) $\mathrm{O}$ desenvolvimento do capitalismo que entretanto se verificou fez com que aquilo que era então um erro se tornasse hoje verdade, e hoje, a tarefa imediata consiste em realizar o que Marx e Engels contavam fazer em $1848^{876}$.

Deste modo, o início do século XX iluminou a incompatibilidade entre as correntes reformistas e revolucionárias, obscurecida durante o período de expansão do movimento. Além disto, colocou em evidência a ambigüidade existente no projeto social-democrata, marcado pela desvinculação entre teoria e prática, que terminou por suscitar o rechaço do socialismo, a descaracterização do partido, o abandono do internacionalismo operário e o enfraquecimento e desorganização da esquerda mundial. A desmobilização, enfraquecimento e desmembramento da social-democracia ainda viria a contribuir para o fortalecimento dos grupos burgueses de extrema direita em inúmeros países da Europa nas primeiras décadas do século XX.

A capitulação dos partidos social-democratas à política imperialista de seus respectivos governos após a deflagração da Primeira Guerra Mundial - e o conseqüente esfacelamento da Segunda Internacional - deu ensejo a numerosos conflitos no interior do socialismo europeu que culminaram em sua efetiva fragmentação. $\mathrm{Na}$ Alemanha, entre os representantes da direita partidária prevaleceu a concepção de que a política nacional deveria

\footnotetext{
875 "O oportunismo não está à altura de construir uma teoria positiva que resista, um mínimo que seja, à crítica" (Ibid, p.119).

${ }^{876}$ LOUREIRO, Maria Isabel. Rosa Luxemburg: vida e obra. São Paulo: Expressão Popular, 2003, p.107.
} 
figurar em primeiro plano - juntamente com seu "direito à autodefesa nacional contra ataques externos agressivos" $" 877$.

Nos anos marcados pelo conflito mundial, com a precarização das condições de vida e a crescente insatisfação popular, as correntes revolucionárias ganharam novo fôlego na Alemanha. A vitória da Revolução de Outubro viria a proporcionar ainda um novo impulso à luta promovida pela ala esquerda da social-democracia - embora ainda restassem dúvidas e receio quanto à adequação do modelo revolucionário bolchevique às condições encontradas no Ocidente.

A conjugação de forças para a institucionalização da República, em 9 de novembro de 1918, logo foi rompida em face da moderação demonstrada pela ala majoritária do SPD. As notórias divergências entre as diferentes correntes do movimento socialista conduziram a novas tentativas de ascender ao poder e instaurar uma república socialista pelo grupo revolucionário - que incluía spartaquistas, alguns membros mais radicais do USPD e dos delegados revolucionários, vinculados a certos sindicatos e conselhos ${ }^{878}$. Estas foram violentamente reprimidas pelo governo social-democrata de Friedrich Ebert, que passou a assumir um caráter conservador em defesa do status quo.

Analisando-se o desfecho trágico da experiência revolucionária alemã, pode-se concluir, em conformidade com o entendimento de Rosa Luxemburg (em artigo de 1915), que, em se tratando do movimento operário,

seus erros são tão gigantescos quanto suas tarefas. Não tem um esquema prévio, válido para sempre, nem um guia infalível que lhe mostra o caminho que deve percorrer; não tem outro mestre que a experiência histórica. O penoso caminho de sua libertação não somente está empedrado de sofrimentos sem limites, mas de inumeráveis erros. Só alcançará sua libertação se souber aprender com seus próprios erros. Para o movimento proletário, a autocrítica, uma autocrítica valente, cruel, que chegue ao fundo das coisas, é o ar e a luz sem os quais não pode viver. ${ }^{879}$

Conquanto precise enfrentar tamanhos obstáculos e dificuldades, o proletariado contaria com um poderoso instrumento a seu favor, pois a teoria marxista teria "colocado nas mãos da classe trabalhadora do mundo inteiro uma bússola" que lhe permitiria "encontrar o

\footnotetext{
${ }^{877}$ Cf. Bernstein, 1996.

${ }^{878}$ Cf. LOUREIRO. A Revolução Alemã, 1918 - 1923. São Paulo: UNESP, 2005.

${ }^{879}$ LUXEMBURG, Rosa. La crisis de la socialdemocracia. México: Roca, 1972, p.11. Escrito em 1915.
} 
caminho no torvelinho dos acontecimentos de cada dia e orientar sua tática de combate em cada momento na direção do imutável objetivo final" ${ }^{180}$.

Portanto, a partir dos valiosos ensinamentos de Rosa Luxemburg, pode-se compreender que o futuro do movimento operário, longe de estar previamente escrito, dependerá da ação das classes trabalhadoras e de sua capacidade de enxergar as possibilidades inscritas no presente, sob uma perspectiva histórica e totalizante, para sua organização e mobilização com vistas à concretização de seu projeto emancipatório.

${ }^{880}$ Ibid, p. 12. 


\section{5 - Consideracões finais sobre a suposta "crise do marxismo"}

Ao longo do século XX, amplos setores da social-democracia expressaram a sua adesão ao reformismo e à crença na evolução pacífica do capitalismo ao socialismo, convertendo o socialismo da condição de antítese teórica e prática do sistema capitalista à condição de um movimento parlamentar integrante deste mesmo sistema.

As origens deste processo, que procuramos elucidar no decorrer deste trabalho, remontam indiscutivelmente ao próprio nascimento do movimento socialista e às inúmeras contradições internas desenvolvidas no processo de sua formação e expansão.

Neste sentido, a polêmica tentativa realizada por Bernstein de reabilitar o que considerava essencial das teses de Marx a partir da rejeição da dialética não deve ser compreendida simplesmente como um empreendimento teórico-filosófico. Sua contestação dos pais fundadores do materialismo histórico está intrinsecamente relacionada com o contexto histórico no qual emergiu o movimento social-democrata e com os inúmeros desafios por ele enfrentados para sua consolidação, na virada do século XIX para o século $\mathrm{XX}$.

Como asseverou István Mészáros, a respeito das correntes reformistas da socialdemocracia ocidental,

Suas ideologias não são, portanto, o resultado de "maquinações insidiosas" e "traições subjetivas". Nem poderiam ser consideradas simplesmente "concepções errôneas" de indivíduos particulares que, apesar de improvável, em princípio poderiam ser levados a reconhecer seus erros e a modificar suas opiniões. Elas são a articulação necessária de um "curtocircuito" histórico em que a ala parlamentarista do movimento da classe trabalhadora ocidental se encontra em uma determinada época de seu desenvolvimento ${ }^{881}$.

Deste modo, é preciso advertir que uma ênfase excessiva na figura de Bernstein e a sobrevalorização de sua influência sobre o movimento operário podem obscurecer o fato de que o revisionismo, na realidade, expressava os desígnios de uma grande parcela do movimento social-democrata, o qual, conforme expôs Bo Gustafsson, desde o princípio

${ }^{881}$ MÉSZÁROS, István. O poder da ideologia. São Paulo: Boitempo, 2004, p.417. 
encontrava-se cindido em "duas almas" distintas, uma pequeno-burguesa-radical-sindical e a outra socialista-revolucionária ${ }^{882}$.

Como explicitara Rosa Luxemburg, as contradições existentes no marxismo "ortodoxo" ${ }^{883}$ - concepção prevalecente entre os dirigentes do Partido Social-Democrata Alemão - terminavam por elevar ao primeiro plano as "tarefas mínimas urgentes" e reduzir o socialismo a "uma estrela brilhando ao longe" ${ }^{\text {"84 }}$. Sendo assim, a estrutura parlamentar e sindical passou a ser aceita como o horizonte limitador de toda ação proletária.

A adesão incondicional à tática legalista culminou na apriorística e categórica rejeição da possibilidade objetiva de mudança social mediante a ação revolucionária dos sujeitos históricos. Sendo a revolução concebida como um produto necessário do desenvolvimento econômico capitalista, restava ao proletariado a espera resignada e paciente pela maturação das condições históricas objetivas.

Por considerar a teoria marxista um obstáculo à "prática positiva" da socialdemocracia - não fazendo distinção entre a versão "vulgarizada" e as teses marxianas propriamente ditas -, Bernstein incumbiu-se da tarefa de desmantelar seu edifício teórico, e, com ele, toda a perspectiva de uma transformação radical da estrutura econômica da sociedade capitalista realizada através da luta de classes. A satisfação das exigências imediatas implicaria, a seu ver, na renúncia ao objetivo final, isto é, à superação do status quo. Para tanto, Bernstein repudiou o método dialético e aderiu a uma concepção histórica que antevia um processo de transformação social pacífico e ininterrupto, nos limites da sociedade capitalista-burguesa.

As ilusões revisionistas relativas à democracia burguesa e a superestimação do alcance das reformas sociais, a serem conquistadas mediante a colaboração entre as classes, levaram à difusão da crença em um progresso gradual e linear em direção à socialização parcial da economia e à crescente democratização da esfera política. Em lugar da crítica da sociedade existente, tal ideologia agarrava-se à forte e otimista convicção de que o elemento moral poderia transcender a fragmentação imposta pelos interesses de classe.

\footnotetext{
882 GUSTAFSSON, Bo. Marxismo y revisionismo: La critica bernsteiniana del marxismo y sus premisas histórico-ideológicas. México: Grijaldo, 1975, p.44.

${ }^{883}$ Denominação atribuída à doutrina formulada a partir da interpretação dos escritos de Marx, realizada pelos dirigentes da Segunda Internacional.

${ }^{884}$ LUXEMBURG, Rosa. “O nosso programa e a situação política”. In : Reforma social ou Revolução? E outros textos. Lisboa: Escorpião, [197-], p.108.
} 
Assim, em nome da libertação do partido de dogmas e doutrinas, o revisionismo promoveu a substituição dos princípios revolucionários marxistas pela Realpolitik, ou seja, pela assunção de um pragmatismo político orientado para o atendimento das necessidades momentâneas e parciais, desde que neste processo sejam observadas as regras impostas pela mesma sociedade que anteriormente se pretendia atacar. Desta maneira, o "beco sem saída bernsteiniano", analisado por Mészáros ${ }^{885}$, produziria uma “amnésia ideológica seletiva"886, confinando a ação do proletariado, como diria Marx, aos "limites do que é autorizado pela polícia e proibido pela lógica» ${ }^{\circledR 87}$. A luta parlamentar, desta forma, passa a ser considerada antítese da ação revolucionária e único instrumento de mudança à disposição da classe operária.

A teorização bernsteiniana, portanto, deve ser analisada tendo-se em conta os conflitos travados no campo do movimento operário, motivados por uma multiplicidade de fatores externos e internos à organização que influíram para o avanço ou o retrocesso da luta de classes, para a aproximação da meta socialista ou a acomodação à ordem capitalista vigente.

Logo, se consideramos equivocada a mistificação da figura de Bernstein, promovida principalmente durante o período stalinista, tampouco minimizamos o papel desempenhado por suas idéias ${ }^{888}$ na chamada "crise do marxismo" $" 889$. No entanto há que se reconhecer que o debate suscitado em função do pronunciamento das teses revisionistas bernsteinianas deu origem a importantes críticas teóricas e a novos questionamentos ${ }^{890}$. Seu mais expressivo legado teórico terá sido incontestavelmente a rediscussão do próprio conceito de dialética ${ }^{891}$.

\footnotetext{
${ }^{885}$ Mézáros, 2004, p.376-377.

${ }^{886}$ Ibid, p. 374.

${ }^{887}$ MARX, Karl. “Crítica ao Programa de Gotha”. In: Critica do Programa de Gotha, Critica do Programa de Erfurt e Marxismo e Revisionismo. Porto: Portucalense, 1971, p. 31.

${ }^{888}$ Conforme Engels convenientemente observara: "o oportunismo "honesto" é talvez o mais perigoso" de todos". Cf. ENGELS, F. Critica do Programa de Erfurt . Porto: Portucalense, 1971, p.48.

${ }^{889}$ Expressão cunhada pelo liberal Masaryk em 1900. Cf. MASARYK, T.H.G. "Die philosophischen und Soziologischen Grundlagen des Marxismus. Studien zur sozialen Frage". Viena, 1899 (Gustafsson, 1975, p.439).

${ }^{890}$ A premissa de Bernstein segundo a qual "todo e qualquer desenvolvimento futuro e elaboração da doutrina marxista deve principiar pela sua crítica” (Bernstein, 1997, p.46) não é avessa à concepção marxiana, expressa por Engels nos seguintes termos: "Mas todo o modo de ver as coisas de Marx não é uma doutrina, mas pontos de referência para a ulterior investigação e o método para tal investigação". Carta de Engels a Sombart de 11/3/1895 (Gustafsson, 1875, p.70).

${ }^{891}$ Devemos ressaltar que, contrariamente a Croce - que proclamara o esgotamento do marxismo teórico em virtude de sua fragmentação doutrinária -, Georges Sorel concebera a "crise" como frutífera e positiva. Segundo sua concepção: "a crise do marxismo marca um longo progresso, possibilita a superação de obstáculos do pensamento - o socialismo não é uma doutrina, uma seita, um sistema político: é a emancipação das classes operárias que se organizam e criam instituições novas" (SOREL, Georges. Reflexões sobre a violência. São Paulo: Martins Fontes, 1992, p. 141). Apesar de todas as críticas e acusações dirigidas aos revisionistas, Lênin compartilhava desta mesma opinião, ao afirmar que "a luta contra os revisionistas serviu para um fecundo reavivamento do pensamento teórico do socialismo internacional, tal como ocorrera 20 anos antes, com a
} 
A crucial relação entre necessidade e liberdade (ou seja, entre as condições materiais de existência e os sujeitos históricos) era resolvida pela filosofia da história determinista difundida marxismo "oficial" - com a preservação da antinomia entre sujeito-objeto e a prevalência do último sobre o primeiro, de forma mecânica e direta, pela invocação de leis naturais. Desta forma, a dialética subjetiva (história humana) seria o mero reflexo da dialética objetiva (história da natureza) e as transformações se produziriam independentemente da vontade ou ação dos homens, em função da própria natureza contraditória do ser. Assim, o papel do homem como sujeito histórico era reduzido ao máximo, perdendo seu próprio caráter revolucionário.

Como posteriormente fora observado por Walter Benjamin, a história concebida como uma "marcha triunfal para o progresso necessário" atribuiu à classe trabalhadora o papel de redentora de gerações futuras, embora, simultaneamente, tenha lhe cortado "o tendão das suas melhores forças", posto que os homens, sujeitos históricos, só poderiam ter noção de sua potência criadora se passassem a enxergar a história como objeto de uma construção que tem lugar "não no tempo vazio e homogêneo, mas no repleno de atualidade" 892 .

Convém ressaltar que para o materialismo histórico clássico é fundamental que o homem tome consciência de si próprio como ser social, simultaneamente sujeito e objeto do devir histórico. Na práxis revolucionária coincidem a mudança das circunstâncias e a transformação da consciência. Deste modo, exclui-se a compreensão de que as ações humanas sejam absorvidas por uma causalidade rígida, cristalizações e determinismos, permitindo que a liberdade seja considerada como algo além da mera constatação da necessidade.

Assim, a concepção marxiana da história opõe-se frontalmente tanto ao materialismo mecanicista quanto ao idealismo voluntarista, pelo fato de entrever nesta relação dialética entre sujeito e objeto, homem e circunstância, atividades humanas e condições dadas, a própria auto-emancipação, a práxis auto-libertadora.

Se o determinismo mecanicista e dogmático adotado pelo marxismo ortodoxo representou, como foi demonstrado, a ocultação do potencial transformador e revolucionário dos sujeitos históricos, por outro lado, a rejeição e exclusão da dialética marxista efetuada por Bernstein posicionou-o do outro lado dos extremos, aproximando-o do idealismo kantiano e

polêmica de Engels com Dühring" (LÊNIN. "Marxismo e revisionismo". In: Obras escolhidas. $3^{\mathrm{a}}$ ed. São Paulo: Alfa-Omega, v. 1, 1986b p.42-43).

892 BENJAMIN, Walter. "Teses sobre filosofia da história”. In: Coleção grandes cientistas sociais. São Paulo: Ática, 1991, p.160. 
da ciência positivista. Deste modo, excluiu de seu sistema teórico todas as patentes contradições do modo de produção capitalista, ocultando-lhe os antagonismos sociais e partindo em defesa de um reformismo não atrelado ao compromisso revolucionário. Como conseqüência, esvaziou a teoria marxista de todo conteúdo crítico e transformador, levando a social-democracia a endossar as teses liberais e a legitimar o sistema capitalista. Por conseguinte, conforme previra Rosa Luxemburg, o revisionismo bernsteiniano levou à descaracterização da social-democracia e à sua identificação com um democratismo liberal apático e comodista.

Levando em consideração as palavras de Marx, segundo as quais "os homens conjuram os espíritos do passado para criarem livremente sua própria história”, podemos aduzir que a recuperação da história do marxismo - através da análise da intensa produção intelectual e atividade política de seus primeiros expoentes - converte-se em um instrumento potencialmente útil para que a presente geração possa, nas palavras de Marx, "encontrar novamente o espírito da revolução" ${ }^{\circledR 93}$.

Como ressaltou Engels, a análise crítica dos sucessos e fracassos do movimento operário não invalida ou enfraquece a sua luta, conferindo novas bases para seu desenvolvimento futuro:

Desde as brilhantes provas que superaram a partir de 1878, tenho confiança incondicional em nossos trabalhadores, e só neles. Assim como todo grande partido, hão de cometer erros em detalhes da evolução, talvez grandes erros. Massas só aprendem através das consequiências dos seus próprios erros, através de experiências no próprio corpo. ${ }^{894}$

Sob este prisma, a crise da social-democracia no início do século XX não deve ser concebida como uma "crise do marxismo" ou uma "crise de alternativas" - o que contribuiria para sustentar a tese do advento do "fim da história". Em contraste, apontaria para a possibilidade de reconstrução dialética do movimento, a partir das novas condições históricas encontradas.

É certo, no entanto, que a dissolução da Segunda Internacional e o abandono dos princípios do internacionalismo operário propiciaram a deflagração de um processo de contínua fragmentação da social-democracia, tendo o reformismo passado a ser uma

\footnotetext{
${ }^{893}$ MARX, Karl \& ENGELS, F. “O 18 Brumário de Luís Bonaparte”. In: Obras escolhidas. São Paulo: AlfaOmega, v. 1, 1980, pp. 204.

${ }^{894}$ Carta de Engels a Conrad Schmidt, de 5/8/1890 (Marx e Engels, 1983, p.457).
} 
tendência dominante nos partidos social-democratas ${ }^{895}$. As décadas de 20 e 30 foram marcadas pela redefinição teórica da social-democracia, que então passara a associar seu programa à implementação do Welfare State e ao repúdio do socialismo soviético. Já em 1921, o Programa de Görlitz do Partido Social-Democrata Alemão passou a adotar oficialmente as concepções revisionistas de Bernstein, que inclusive participara de sua redação.

O reconhecido "desvio à direita" da social-democracia européia se acentuara no segundo pós-guerra em razão do financiamento americano da reconstrução européia e da emergência da Guerra Fria. O coroamento deste redirecionamento político ocorreu nos fins da década de 50, quando grande parte dos partidos europeus rompeu os laços remanescentes que os vinculavam ao socialismo e à doutrina marxista ${ }^{896}$. Como anunciou Mészáros,

não só os partidos reformistas da social-democracia ocidental foram sugados cada vez mais profundamente para $o$ parlamentarismo burguês - que, do ponto de vista do trabalho, não proporciona nenhuma esperança - mas também vários dos partidos de trabalhadores da Terceira Internacional, originalmente anti-reformistas, seguiram o mesmo caminho, com a social-democratização de quase todos os partidos comunistas ocidentais. ${ }^{897}$

Contudo, a abertura crítica e o distanciamento em relação a paradigmas doutrinários previamente determinados contribuíram igualmente para a revitalização do marxismo, ou, nas palavras de Hobsbawm, para o "declínio das ortodoxias"898.

As velhas certezas - sobre o futuro do capitalismo, sobre as forças sociais e políticas que se espera possam provocar a transição para um novo sistema social, sobre a natureza e as perspectiva das sociedades que já hoje declaram ter posto em andamento essa transformação - todas essas certezas foram colocadas em dúvida. Ou melhor, não existem mais. A teoria fundamental do marxismo, inclusive o próprio pensamento de Marx, está submetida a um profundo reexame crítico e a uma série de reformulações em polêmica entre si, mas, em geral, de grande alcance ${ }^{899}$.

\footnotetext{
895 Após a tentativa de levante ocorrida em 1919, a Liga Espartaquista seria severamente reprimida, tendo seus principais dirigentes sido assassinados no mesmo ano.

896 Ocorre na Áustria e Suíça em 1958, na Holanda e Alemanha (Programa de Bad-Godsberg) em 1959, na Suécia em 1960 e na França em 1962 (Przeworski, 1989).

${ }^{897}$ MÉSZÁROS, István. O poder da ideologia. São Paulo: Boitempo, 2004, p.415-416.

${ }^{898}$ Isto é, o desaparecimento de qualquer ortodoxia internacional dominante ou obrigatória, comparável ao marxismo do SPD e ao marxismo-leninismo do período soviético no período de sua hegemonia sobre o marxismo mundial (HOBSBAWM, E. "O marxismo hoje: um balanço aberto". In: História do marxismo XI: o marxismo hoje - primeira parte. Rio de Janeiro: Paz e Terra, 1983).

${ }^{899}$ Ibid, p.61.
} 
Neste sentido, a produção intelectual de teóricos ${ }^{900}$ como Korsch, Lukács, Horkheimer, Adorno, Benjamin e Marcuse e a penetração do marxismo nas universidades a partir da década de 50 abriram espaço para o debate entre diferentes interpretações do marxismo, constituindo tendências ideológicas e facções rivais dentro dos partidos, grupos e organizações. O novo "pluralismo" permitiria inclusive combinações com outras ideologias $^{901}$ :

Tornou-se mais difícil considerar as interpretações heterodoxas como efetivamente não-marxistas, e, inversamente, a tentação dos socialistas que divergiam da ortodoxia de romper os laços com Marx se atenuou proporcionalmente. No plano político, isto é resultado evidente da fragmentação do movimento comunista internacional, das incertezas sobre a estratégia e as perspectivas dos partidos operários socialistas no resto do mundo, da tendência de outros movimentos e partidos que aspiram a uma mudança radical para usar o distintivo de Marx entre seus lemas ideológicos ${ }^{902}$.

As experiências revolucionárias levadas a cabo em países periféricos, a lenta reestruturação e reorganização do movimento sindical na Europa após o fim da Segunda Guerra, a influência dos acadêmicos e estudantes oriundos da burguesia e pequena-burguesia, e os novos atores políticos que desempenharam papel central no ressurgimento da esquerda na década de 60 - como o movimento negro, feminista e de libertação nacional - promoveram a intensa rediscussão acerca das táticas e projetos de transformação social.

O final do século XX, no entanto, causaria ainda maior impacto no seio da esquerda mundial. As promessas de "renovação da social-democracia" pela adoção de uma "terceira via" condizente com a política neoliberal, a queda do muro de Berlim, a abertura comercial na China e o desmantelamento da União Soviética provocaram a prevalência de um discurso único e o abandono progressivo de vários pressupostos básicos das teses social-democratas de defesa do aperfeiçoamento gradual, ainda que limitado, do sistema capitalista por meio de reformas legislativas. A nova "crise" das esquerdas reavivou antigas fórmulas que

\footnotetext{
${ }^{900}$ Como assevera Hobsbawm, "uma conseqüência dessa pluralidade do marxismo, com limites indefinidos, e do declínio simultâneo de interpretações sustentadas pelo carisma foi o reaparecimento dos "teóricos". No entanto, diferentemente do período anterior a 1914, o "teórico" não está mais estreitamente ligado a uma organização política particular e muito menos a uma linha política; menos ainda desempenha uma função política importante, ainda que às vezes informal, como acontecera com Kautsky" (Ibid, p.49).

901 "É típico do pluralismo desse período que não somente a natureza de seu marxismo mas também sua efetiva relação com ele se revelem às vezes pouco claras" (Ibid, p.49).

902 Ibid, p. 48.
} 
anunciavam o "fim da história", o "fim das ideologias" e o "fim das utopias", colocando novamente a dialética no centro das discussões.

Contudo, a "solução" neoliberal à crise do Estado assistencialista, baseada na desregulamentação dos direitos trabalhistas e na eliminação das políticas públicas de proteção social, revelou, em um curto espaço de tempo, seu caráter ideológico e sua completa incapacidade de afastar as recorrentes crises econômicas estruturais que ganham hodiernamente uma dimensão mundial. Ao contrário, tornou cada vez mais evidentes as contradições decorrentes da lógica de acumulação do capital e do avanço do sistema capitalista em escala global, através do incremento da miséria, dos índices de desemprego e exclusão, da desigualdade social, da degradação ambiental e dos conflitos entre nações.

Diante deste novo cenário histórico, torna-se tarefa fundamental da tradição marxista o resgate do pensamento crítico e do ímpeto transformador. Assim, o trabalho de revisão das táticas, estratégias e da própria doutrina deve ser conjugado à necessária radicalização e revigoramento da luta de classes, com vistas à superação da ordem social burguesa. Deste modo, deve-se retomar a crítica radical sem, com isso, negligenciar o exame das possibilidades reais de ação e a mensuração do perigo concreto representado pelas forças da reação. Como ressalta Michael Löwy,

É tempo de reencontrar a dimensão utópico-revolucionária do marxismo e de redescobrir o valor do socialismo como um projeto de futuro, uma esperança para a humanidade oprimida, um combate que prossegue. (...) Essa fé e essa utopia não são um sonho: elas se apóiam em uma análise lúcida, rigorosa, implacável da realidade, que nos mostra que a "prosperidade" prometida pelo sistema capitalista mundial é necessariamente o privilégio de uma elite cada vez mais diminuta. ${ }^{903}$

Assim, o materialismo histórico - e sua concepção dialético-revolucionária - mais uma vez mostra-se indispensável para a compreensão da realidade presente, dinâmica e contraditória. Consoante observado por Rosa, a teoria marxista continua a ser um poderoso instrumento colocado à disposição das classes trabalhadoras para o combate da ordem capitalista, justamente por se encontrar vinculado a um projeto revolucionário radical, que objetiva a emancipação humana de toda exploração e dominação de classe.

Pode-se concluir, por fim, que contrariamente ao defendido por Bernstein, a dialética seria da própria essência do marxismo, não podendo ser descartada sem que se comprometa

${ }^{903}$ LÖWY, M. "Além do neoliberalismo: a alternativa socialista". In: Neoliberalismo, a tragédia de nosso tempo. São Paulo: Cortez, 2000, p. 38. 
todo o edifício teórico desta teoria, retirando-lhe seu conteúdo crítico e radical. Como Marx tão eficazmente sintetizou, seu maior trunfo consiste precisamente no fato de que, "no entendimento positivo do existente ela inclui ao mesmo tempo o entendimento da sua negação, da sua desaparição inevitável; porque apreende cada forma existente no fluxo do movimento, portanto também com seu lado transitório; porque não se deixa impressionar por nada e é, em sua essência, crítica e revolucionária"904.

Conseqüentemente, toda renovação crítica do marxismo deve - em lugar de preservar dogmas ou venerar mitos - aprofundar seu sentido histórico e crítico, sem desprezar sua dimensão revolucionária. Eis o grande desafio a ser enfrentado pelo marxismo neste século XXI.

${ }^{904}$ MARX, Karl. O Capital: Crítica da Economia Política. vol.1, livro I. São Paulo: Nova Cultural, 1985a, p. 21. 


\section{6 - Referências Bibliográficas}

ANDERSON, Perry. Considerações sobre o marxismo ocidental. $2^{\mathrm{a}}$ ed. São Paulo: Brasiliense, 1989.

BANDEIRA, Luiz A. M. A reunificação da Alemanha: do ideal socialista ao socialismo real. Brasília: UNB, 2001.

BAKUNIN, Mikhail. Estatismo e anarquia. São Paulo: Editora Imaginário, 2003.

BENJAMIN, Walter. "Teses sobre filosofia da história”. In: Coleção grandes cientistas sociais. São Paulo: Ática, 1991.

BENOIT, Hector. "Da dialética da natureza a derradeira estratégia política de Engels". In: A obra teórica de Marx: atualidade, problemas e interpretações. São Paulo: Xamã, 2000, pp. 91-107.

BERNSTEIN, Eduard. Ferdinand Lassale: le réformateur social. Paris: Marcel Rivière, 1913.

. Cromwell and communism: socialism and democracy in the great English Revolution. New York: Kelley, 1966a.

_ _El mensaje de Bernstein al Congresso de Stuttgart”. In: Socialismo teórico y socialismo práctico. Buenos Aires: Editorial Claridad, 1966b.

_. Las Premisas del socialismo y las tareas de la socialdemocracia. Problemas del socialismo. El revisionismo en la socialdemocracia. México: Siglo Veintiuno, 1982.

_. Selected writings of Eduard Bernstein: 1900 - 1921. New Jersey: Humanities Press, 1996.

_. Socialismo evolucionário. Rio de Janeiro: Zahar, 1997.

BERTELLI, Antonio Roberto. Marxismo e transformações capitalistas. São Paulo: IPSO; IAP, 2000.

. Revisionismo e ortodoxia no marxismo. São Paulo: IPSO; IAP, 2003.

BÖHM-BAWERK, Eugen von. "Teoria positiva do capital”. v. II. In: Coleção os Economistas. São Paulo: Nova Cultural, 1986.

BOTTOMORE, Tom [org]. Austro-marxism. London: Clarendon Press - Oxford University Press, 1978.

. [org]. Dicionário do pensamento marxista. Rio de Janeiro: Jorge Zahar, 2001.

CARONE, Edgard. A II Internacional pelos seus congressos (1889-1914). São Paulo: Edusp, 1993.

COGGIOLA. Osvaldo (org.). Escritos sobre a Comuna de Paris. São Paulo: Xamã, 2002. 
O segundo violino. São Paulo: Xamã, 1995.

COLE, George Douglas Howard. Historia del pensamiento socialista: la segunda internacional: 1889- 1914. México: Fondo de Cultura Economica, v.1, 1959.

COLLETI, Lucio. El marxismo y el derrumbe del capitalismo. México: Siglo Veintiuno, 1985.

__. Ultrapassando o marxismo. Rio de Janeiro: Forense universitária, 1983.

DROZ, Jacques. Histoire générale du socialisme - tomo II. Paris: Presses Universitaires de France, 1974.

_.. Europa: restauracion y revolucion 1815-1848. Madrid: siglo veintiuno, 1988.

ELEY, Geof. Forjando a democracia: a história da esquerda na Europa, 1850-2000. São Paulo: Fundação Perseu Abramo, 2005.

ELIAS, Norbert. Os alemães: a luta pelo poder e a evolução do habitus nos séculos XIX e $X X$. Rio de Janeiro: Jorge Zahar, 1997.

ENGELS, Friedrich. Anti-Dühring. Rio de Janeiro: Paz e Terra, 1979.

_. "Os bakunistas em ação". In: O anarquismo e a democracia burguesa. São Paulo: Global, 1980.

_. "Friedrich Engels: Política". José Paulo Netto [org]. In: Coleção Grandes Cientistas Sociais, n. 17, São Paulo: Ática, 1981.

EVANGELISTA, João E. Crise do marxismo e irracionalismo pós-moderno. São Paulo: Cortez, 1997.

FETSCHER, Iring. "Bernstein e o desafio à ortodoxia". In: História do marxismo II: o marxismo na época da Segunda Internacional - primeira parte. [org.] Eric J. Hobsbawm. Rio de Janeiro: Paz e Terra, 1982.

GARCIA, Marco Aurélio. "Reforma e revolução / reforma ou revolução". In: Revista Brasileira de História. São Paulo: ANPUH/Marco Zero, vol.10, n.20 - março/agosto de 1990.

GAY, Peter. The dilemma of democratic socialism. New York: Columbia University Press, 1970.

GERAS, Norman. A actualidade de Rosa Luxemburg. Lisboa: Antídoto, 1978.

GRANOV, V. O revisionismo de direita. Lisboa: Estampa, 1976.

GUÉRIN, Daniel; et allii. O anarquismo e a democracia burguesa. São Paulo: Editora Global, 1980. 
_. Rosa Luxemburg e a espontaneidade revolucionária. São Paulo: Editora Perspectiva, 1982.

GUSTAFSSON, Bo. Marxismo y revisionismo: La critica bernsteiniana del marxismo y sus premisas histórico-ideológicas. México: Grijaldo, 1975.

HILFERDING, Rudolf. "A democracia e a classe trabalhadora". In: Utópicos, heréticos e malditos. [org.] Aloísio Teixeira. Rio de Janeiro: Editora Record, 2002.

HOBSBAWM. Eric J. (org). História do marxismo II: o marxismo na época da Segunda Internacional - primeira parte. Rio de Janeiro: Paz e Terra, 1982.

__. "O marxismo hoje: um balanço aberto". In: História do marxismo XI: o marxismo hoje primeira parte. Rio de Janeiro: Paz e Terra, 1983.

- (org). História do marxismo III: o marxismo na época da Segunda Internacional segunda parte. Rio de Janeiro: Paz e Terra, 1984a.

__ (org). História do marxismo IV: o marxismo na época da Segunda Internacional terceira parte. Rio de Janeiro: Paz e Terra, 1984b.

__. Revolucionários. $2^{\mathrm{a}}$ ed. Rio de Janeiro: Paz e Terra, 1985.

_ . "Aspectos políticos de transição do capitalismo ao socialismo". In: História do marxismo I: o marxismo no tempo de Marx. Rio de Janeiro: Paz e Terra, 1987, p.301-346.

_. A era dos impérios. São Paulo: Paz e Terra, 2005.

HOBSON, John Atkinson. “A evolução do capitalismo moderno”. In: Os economistas. São Paulo: Nova Cultural, 1985.

HOFMANN, Werner. A história do pensamento do movimento social dos séculos 19 e 20 . Rio de Janeiro: Tempo Brasileiro, 1984.

JOLL, James. La Segunda Internacional. Movimiento obrero 1889-1914. Barcelona: Icalia, 1976.

KAUTSKY, Karl. Le programme socialiste. Paris: Librairie des sciences politiques et sociales Marcel Rivière, 1927.

_. La doctrina socialista. Buenos Aires: Claridad, 1966. Ética y concepción materialista de la historia. Córdoba: Pasado y Presente, 1975. “"La revolución social. El camino del poder". In: Cuadernos de pasado y presente, n. 68. México, D.F: PYP, 1978.

__. A ditadura do proletariado. São Paulo: Ed. Ciências Humanas, 1979. As três fontes do marxismo. São Paulo: global, 1982. 
. "Dois artigos para uma revisão". In: Utópicos, heréticos e malditos / [org.] Aloísio Teixeira. Rio de Janeiro: Record, 2002.

__. "Socialism and colonial policy". In: <www.marxists.com>, acesso em 20/2/2006.

KOLAKOWSKI, Leszek. Las principales corrientes del marxismo. Su nacimiento, desarrollo y disolución. Madrid: Alianza, 1985.

KONDER, Leandro. A derrota da dialética. Rio de Janeiro: Campus, 1988.

KORSCH, Karl. Marxisme et philosophie. Paris: Les éditions de minuit, 1964.

_.. Teoría marxista y acción política. México: Pasado y Presente, 1979.

LASSALLE, Ferdinand. A essência da Constituição. Rio de Janeiro: Líber Júris, 1988.

_. Manifesto operário e outros textos. Brasília: Instituto Teotônio Vilela, 1999.

LEBFVRE, Henri. Para compreender o pensamento de Karl Marx. Lisboa: Edições 70, 1966.

Lógica formal / lógica dialética. Rio de Janeiro: Civilização Brasileira, 1975.

LENINE, V.I. "Duas táticas da social-democracia na Revolução Democrática". In: Obras escolhidas. $3^{\mathrm{a}}$ ed. São Paulo: Alfa-Omega, v. 1, 1986a.

."Marxismo e revisionismo". In: Obras escolhidas. $3^{\mathrm{a}}$ ed. São Paulo: Alfa-Omega, v. 1, 1986b.

— . "O imperialismo, fase superior do capitalismo". Obras escolhidas. $3^{\mathrm{a}}$ ed. São Paulo: Alfa-Omega, v. 1, 1986c.

_. “Que fazer?”. In: Obras escolhidas. $3^{\mathrm{a}}$ ed. São Paulo: Alfa-Omega, v. 1, 1986d.

. "Um passo em frente, dois passos atrás". In: Obras escolhidas. $3^{\mathrm{a}}$ ed. São Paulo: AlfaOmega, v. 1, 1986e.

• "O Estado e a revolução". In: Obras escolhidas. 2a ed. São Paulo: Alfa-Omega, v. 2, 1988a.

_. "A revolução proletária e o renegado Kautsky". In: Obras escolhidas. 2.ed. São Paulo: Alfa-Omega, v. 3, 1988b.

_ _ "Teses sobre a Assembléia Constituinte: um novo livro de Vandervelde sobre o Estado". In: Obras escolhidas. 2.ed. São Paulo: Alfa-Omega, v. 3, 1988c.

LOUREIRO, Isabel Maria. Rosa Luxemburg: os dilemas da ação revolucionária. São Paulo: UNESP, 1995.

_. Rosa Luxemburg: vida e obra. São Paulo: Expressão popular, 2003. . A Revolução Alemã, 1918 - 1923. São Paulo: UNESP, 2005. 
LÖWY, Michael. A evolução política de Lukács (1909-1929). São Paulo: Cortez, 1998.

_. "Além do neoliberalismo: a alternativa socialista". In: Neoliberalismo, a tragédia de nosso tempo. São Paulo: Cortez, 2000.

_. Walter Benjamin: aviso de incêndio. São Paulo: Boitempo, 2005.

LUKÁCS, Georg. Historia y consciencia de clase. Barcelona: Grijalbo, 1975.

_. História e consciência de classe. Rio de Janeiro: Elfos, 1989.

LUXEMBURG, Rosa. Oeuvres I (Reforme ou révolution? Grève de masse, parti et syndicats). Paris: François Maspero, 1969.

_. La crisis de la socialdemocracia. México: Roca, 1972.

_. "O nosso programa e a situação política". In : Reforma social ou Revolução? E outros textos. Lisboa: Escorpião, [197-].

_. A acumulação do capital. $2^{\mathrm{a}}$ ed. Rio de Janeiro: Jorge Zahar, $1976 \mathrm{a}$.

Reforma, revisionismo e oportunismo. Rio de Janeiro: Civilização brasileira, $1976 b$.

. "Estacionamentos e progressos do marxismo". In: Marxismo. São Paulo: Unitas, [198-] .

. Reforma social ou revolução. São Paulo: Global Editores, 1986.

Camarada e amante: cartas de Rosa Luxemburg a Leo Jogiches. Rio de Janeiro: Paz e Terra, 1983.

_. A revolução russa. Petrópolis: Vozes, 1991.

MANDEL, Ernest. A teoria leninista da organização. São Paulo: Antídoto, 1975.

MARCUSE, Herbert. "A obsolescência do marxismo". In: Opções de esquerda. Rio de Janeiro: Paz e Terra, 1972.

_. A ideologia da sociedade industrial. Rio de Janeiro: Zahar, 1978.

MARX, Karl. O Capital: Crítica da Economia Política. vol.1, livro I. São Paulo: Nova Cultural, 1985a.

. O Capital: Crítica da Economia Política. vol. 4, Livro III. São Paulo: Nova Cultural, 1985b.

_.. O Capital - Edição Resumida. Rio de Janeiro: Zahar, 1969.

. Miséria da filosofia. Porto: Escorpião, 1976.

MARX, Karl \& ENGELS, F. Critique des programmes de Gotha et d'Erfurt. Paris: Éditions sociales, 1950. 
_. De la "liga de los justos” al partido comunista. México: Roca, 1973.

_. Obras escolhidas. São Paulo: Alfa-Omega, v. 1, 1980a.

_. Obras escolhidas. São Paulo: Alfa-Omega, v.2, 1980b.

Obras escolhidas. São Paulo: Alfa-Omega, v.3, 1980c.

Coleção grandes cientistas sociais. n.36. [org. FERNANDES, Florestan]. São Paulo: Ática, 1983.

MARX, Karl; ENGELS, F; LENIN, V. I. Critica do Programa de Gotha, Critica do Programa de Erfurt e Marxismo e Revisionismo. Porto: Portucalense, 1971. . Antologia sobre o materialismo dialético. Lisboa: Assírio \& Alvim, 1975. Acerca del anarquismo y el anarcosindicalismo. Moscou: Progreso, 1976.

MAYER, Arno J. A força da tradição. São Paulo: Companhia das Letras, 1987.

MÉSZÁROS, István. O poder da ideologia. São Paulo: Boitempo, 2004.

MICHELS, Robert. Os partidos políticos. São Paulo: Senzala, [196-].

MILLS, Wright. Os marxistas. Rio de Janeiro: Zahar, 1963.

MOORE Jr. Barrington. As origens da ditadura e da democracia. São Paulo: Martins Fontes, 1983.

_. Injustiça: as bases sociais da obediência e da revolta. São Paulo: Brasiliense, 1987.

MUSSE, Ricardo. Do socialismo científico à teoria crítica: modificações na autocompreensão do marxismo entre 1878 e 1937. São Paulo: USP/FFLCH [Tese], 1998.

_. "O primeiro marxista". In: A obra teórica de Marx: atualidade, problemas $e$ interpretações. São Paulo: Xamã, 2000, pp. 81-90.

NETTO, José Paulo. Crise do socialismo e ofensiva neoliberal. São Paulo: Cortez, 2001.

PERROT, Michele. As mulheres e os silêncios da História. São Paulo: EDUSC, 2005.

PROUDHON, Pierre-Joseph. Coleção Grandes Cientistas Sociais/ org. Paulo Edgar A. Resende, Edson Passetti. São Paulo: Ática, 1986.

_. O que é a propriedade?. Lisboa: Estampa, 1997.

PRZEWORSKI, Adam. Capitalismo e social-democracia. São Paulo: Companhia das Letras, 1989.

RAMANOSK, Marcelo. "A poderosa indústria química alemã”. In: Desvendando a história. Ano 1, n.6. São Paulo: Escala educacional, 2005, p.35-43.. 
RIAZANOV, David. Marx - Engels e a história do movimento operário. São Paulo: global, 1984.

RINGER, Fritz K. O declínio dos mandarins alemães: a comunidade acadêmica alemã, 1890-1933. São Paulo: Edusp, 2000.

ROCHA, Ronald. "Dois violinos e uma só harmonia". In: A obra teórica de Marx: atualidade, problemas e interpretações. São Paulo: Xamã, 2000.

RODES, John E. Germany: a history. New York: Holt, Rinehart and Winston, 1964.

SANTOS, Ariovaldo. Marx, Engels e a luta de partido na Primeira Internacional (18641874). Londrina: UEL, 2002.

SCHORSKE, Carl E. German social democracy. 1905- 1917: The development of the great schism. New York: Harper Torchbooks, 1972.

SHAW, Bernard. "A transição para a social-democracia". In: Utópicos, heréticos e malditos / [org.] Aloísio Teixeira. Rio de Janeiro: Record, 2002.

SOMBART, Werner. Le socialisme et le mouvement social au XIX siècle. Paris: Girard \& Brière, 1898.

SOREL, Georges. Reflexões sobre a violência. São Paulo: Martins Fontes, 1992.

STEGER, Manfred B. The quest for evolutionary socialism. New York: Cambridge Press, 1997.

STEINBERG, Hans-Josef. "O partido e a formação da ortodoxia marxista". In: História do marxismo: o marxismo na época da Segunda Internacional - primeira parte. Rio de Janeiro: Paz e Terra, 1982.

STONE, Norman. La Europa transformada 1878-1919. Madrid: siglo veintiuno, 1985.

TEXIER, Jacques. Revolução e democracia em Marx e Engels. Rio de Janeiro: UFRJ, 2005.

TROTSKI, Leon. O Anti-Kautsky. Coimbra: Nosso tempo, 1972.

VIATKIN, A. Movimiento obrero comunista y de liberación nacional. tomo I. Habana: Editorial de Ciencias Sociales, 1982.

WEBB, Sidney. "As bases históricas do socialismo". In: Utópicos, heréticos e malditos / [org.] Aloísio Teixeira. Rio de Janeiro: Record, 2002.

WEBER, Max. "Parlamentarismo e governo numa Alemanha reconstruída: uma contribuição à crítica política do funcionalismo e da política partidária". In: Coleção Os pensadores. São Paulo: Abril Cultural, 1974.

. "Ensaios de sociologia". In: Coleção Os pensadores. São Paulo: Abril Cultural, 1974, cap.XIV e XV. 


\section{$\underline{\text { ANEXOS }}$}

Figura 1: Mapa da Alemanha - 1871

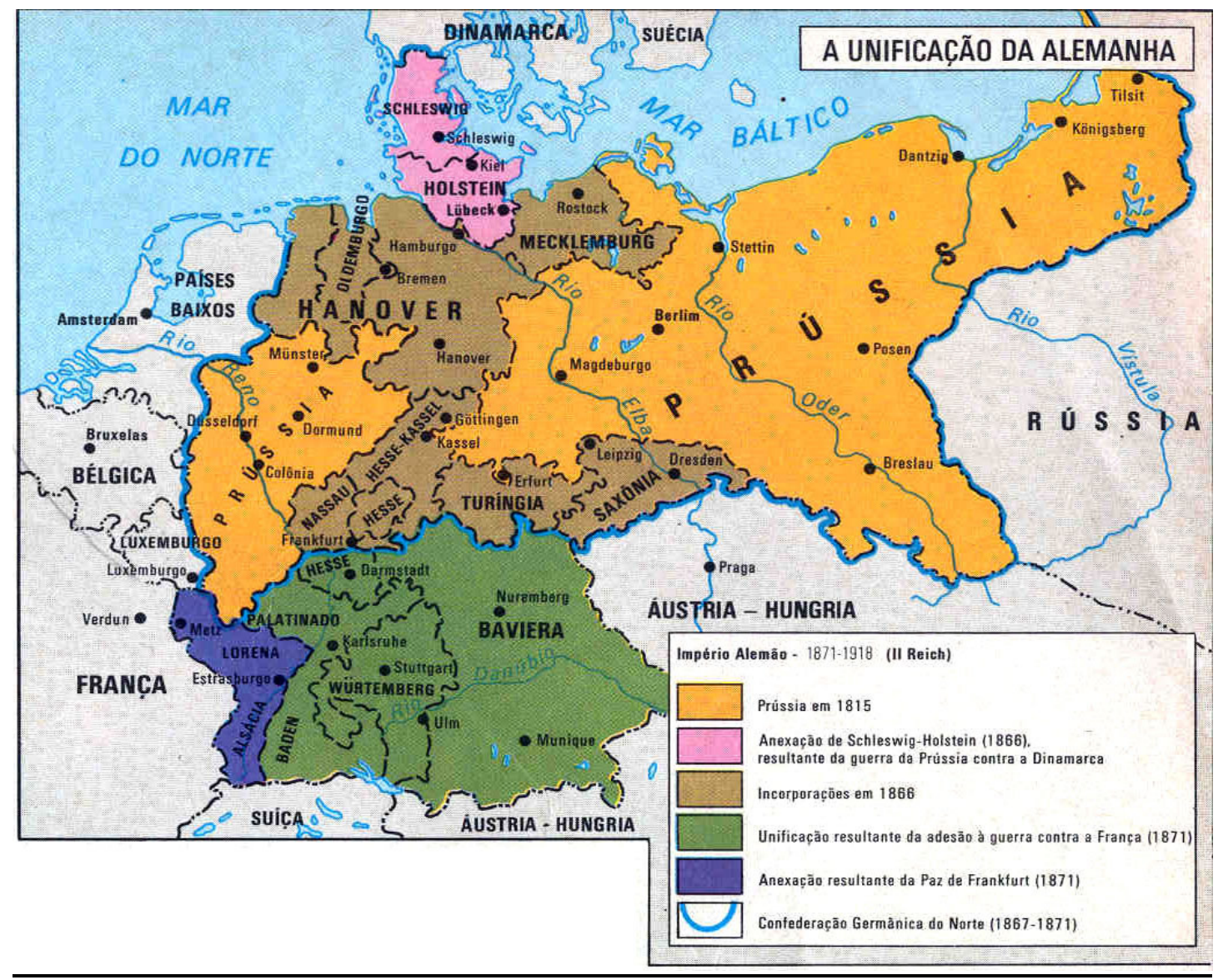

Fonte: ARRUDA, José Jobson de A. Atlas histórico básico. São Paulo: Atlas, p.27. 
Figura 2: Mapa da Alemanha indicando o resultado das eleições para o Reichstag em $1898 . .^{905}$

JULY $16,1898 . \quad$ JUSTICE.

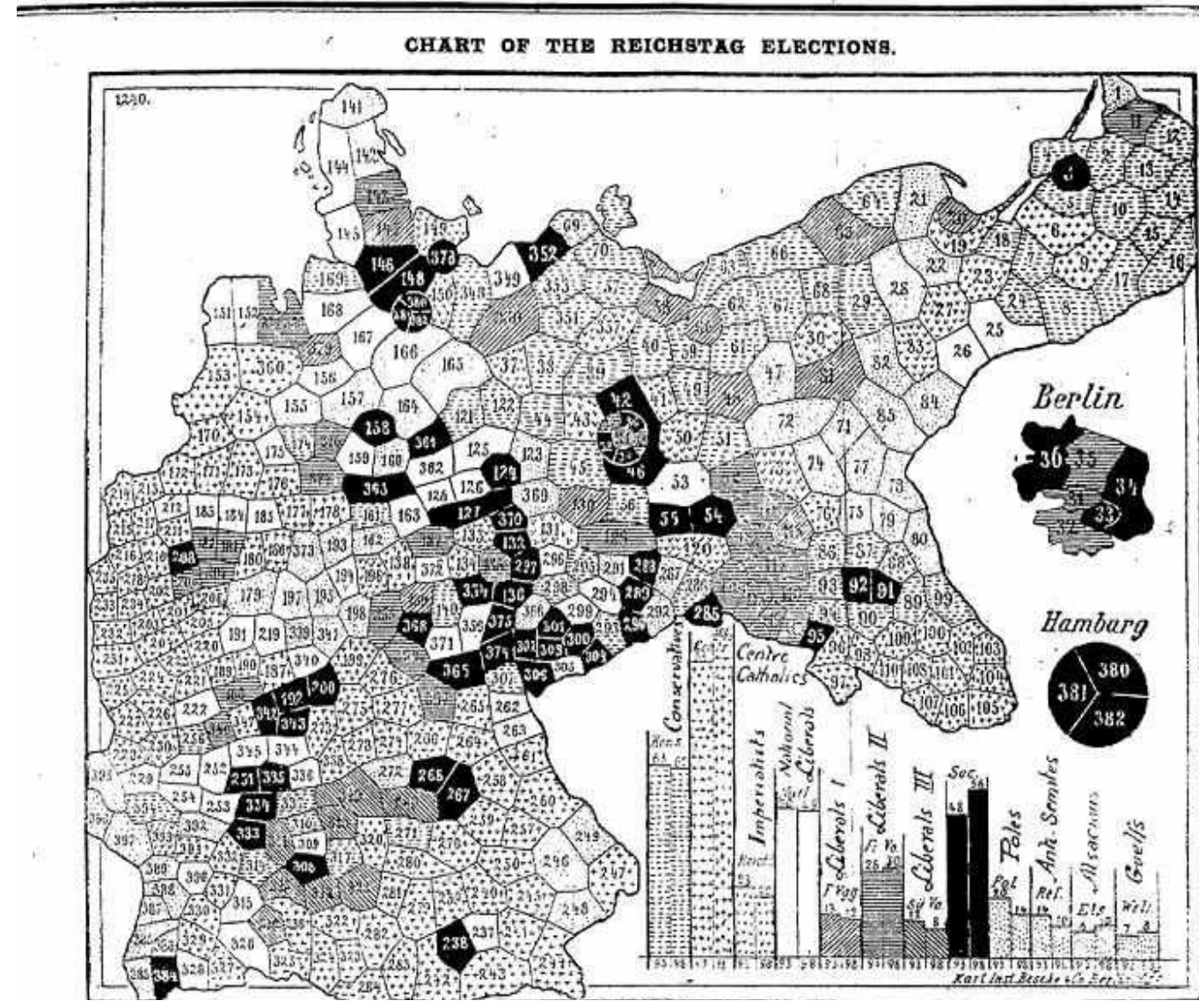

Fonte: LIEBKNECHT, "Socialdemocracy in Germany". In: Justice (16.7.1898), apud $<w w w . m a r x i s t s . o r g>$.

${ }^{905}$ Os distritos onde os social-democratas foram eleitos para o Reichstag foram coloridos de preto. 
Gráfico 1: Progressão dos votos obtidos pelo SPD nas eleições para o Reichstag, de 18711912

Chate 5 ELECTION RESULTS, 1871-1912

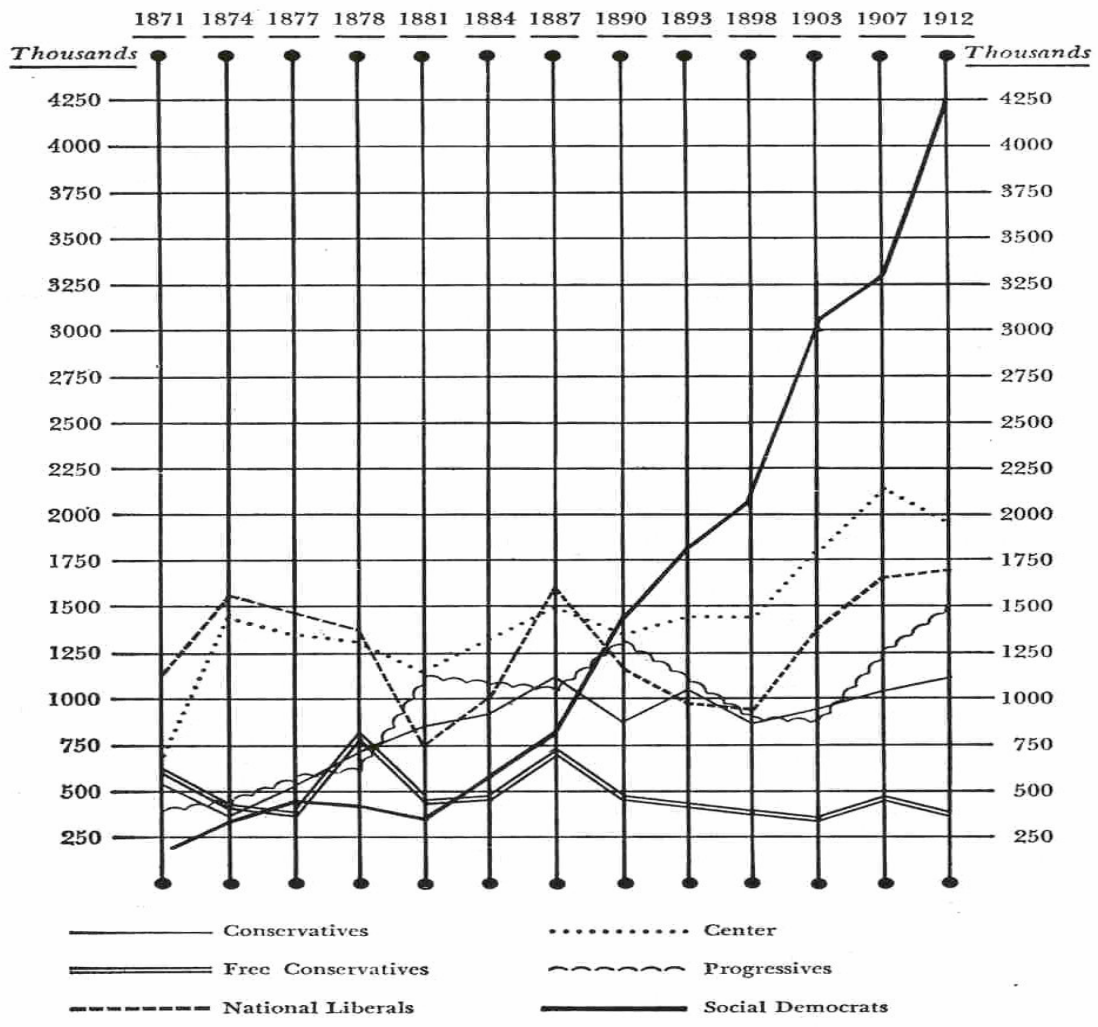

Fonte: RODES, John E. Germany: a history. New York: Holt, Rinehart and Winston, 1964, p.385.

Tabela 1: Votos obtidos pelo SPD nas eleições para o Reichstag, de 1871-1912.

\begin{tabular}{|c|c|c|c|}
\hline Ano & $\mathbf{N}^{\mathbf{0}}$ de votos & percentual & Cadeiras no Parlamento \\
\hline 1871 & 124.655 & 3 & 2 \\
\hline 1874 & 351.952 & 6,8 & 10 \\
\hline 1877 & 493.158 & 9,1 & 13 \\
\hline 1878 & 437.158 & 7,6 & 76 \\
\hline 1881 & 311.961 & 6,1 & 13 \\
\hline 1884 & 549.128 & 9,7 & 24 \\
\hline 1887 & 763.128 & 10,1 & 11 \\
\hline 1890 & 1.427 .298 & 19,7 & 35 \\
\hline 1893 & 1.786 .738 & 23,3 & 44 \\
\hline 1898 & 2.107 .076 & 27,2 & 56 \\
\hline 1903 & 3.010 .771 & 31,7 & 81 \\
\hline 1907 & 3.259 .020 & 28,2 & 43 \\
\hline 1912 & 4.250 .329 & 34,8 & 110 \\
\hline
\end{tabular}

Fonte: CARONE, Edgard. A II Internacional pelos seus congressos (1889-1914). São Paulo: Edusp:1993, p.9 
Tabela 2: Federações Sindicais na Europa.

\begin{tabular}{|l|c|c|l|}
\hline País / Partido & $\begin{array}{l}\text { Ano de } \\
\text { criação do } \\
\text { partido }\end{array}$ & $\begin{array}{l}\text { Ano de } \\
\text { criação das } \\
\text { associações } \\
\text { sindicais }\end{array}$ & Federação Sindical Nacional \\
\hline Grã-Bretanha (LP) & 1900 & 1868 & Congresso dos Sindicatos \\
\hline Espanha (PSOE) & 1879 & 1888 & $\begin{array}{l}\text { Sindicato Geral do Trabalhador } \\
\text { Espanhol }\end{array}$ \\
\hline Alemanha (SPD) & 1875 & 1891 & Comissão Geral dos Sindicatos Livres \\
\hline Hungria (MSZP) & 1880 & 1891 & Conselho dos Sindicatos \\
\hline Áustria (SPÖ) & 1889 & 1893 & Comissão dos Sindicatos \\
\hline Terras tchecas (CSDSD) & 1878 & 1897 & Comissão dos Sindicatos \\
\hline Bélgica (POB) & 1885 & 1898 & Federação Geral do Trabalhador Belga \\
\hline Dinamarca (SDF) & 1876 & 1898 & Confederação dos Sindicatos \\
\hline Suécia (SAP) & 1889 & 1898 & Confederação dos Sindicatos \\
\hline Noruega (DNA) & 1887 & 1899 & Confederação dos Sindicatos \\
\hline Bulgária (BWSDP) & 1891 & 1904 & Sindicato Geral dos Trabalhadores \\
\hline Holanda (DAS) & 1881 & 1906 & Federação dos Sindicatos \\
\hline Itália (PSI) & 1892 & 1906 & Confederação Geral do Trabalhador \\
& & & Italiano \\
\hline
\end{tabular}

Fonte: ELEY, Geof. Forjando a democracia: a história da esquerda na Europa, 1850-2000. São Paulo: Fundação Perseu Abramo, 2005, p.98.

Tabela 3: Número de empresas de acordo com os censos industriais alemães.

\begin{tabular}{|l|c|c|c|c|}
\hline \multirow{2}{*}{} & \multicolumn{2}{|c|}{1882} & \multicolumn{2}{c|}{1895} \\
\cline { 2 - 5 } & $\begin{array}{l}\text { Número de } \\
\text { empresas }\end{array}$ & $\begin{array}{l}\text { Porcentagem de } \\
\text { Empresas }\end{array}$ & $\begin{array}{l}\text { Número } \\
\text { Empresas }\end{array}$ & $\begin{array}{l}\text { Porcentagem de } \\
\text { empresas }\end{array}$ \\
\hline $\begin{array}{l}\text { Empresas } \\
\text { individuais }\end{array}$ & 755.176 & 61.8 & 674.042 & 57.5 \\
\hline $\begin{array}{l}\text { Pequenas } \\
\text { empresas } \\
\text { (1 a 5 operários) }\end{array}$ & 412.424 & 33.7 & 409.332 & 34.9 \\
\hline $\begin{array}{l}\text { Empresas } \\
\text { medianas } \\
\text { (6-50 operários) }\end{array}$ & 49.010 & 4 & 78.627 & 6.7 \\
\hline $\begin{array}{l}\text { Grandes } \\
\text { empresas } \\
\text { (acima de } \\
\text { operários) }\end{array}$ & 51.529 & 0.5 & 10.139 & 0.9 \\
\hline Total & 1.222 .139 & 100 & 1.172 .140 & 100 \\
\hline
\end{tabular}

Fonte: BERNSTEIN. "La lucha de la socialdemocracia y la revolución de la sociedad". In: Las Premisas del socialismo y las tareas de la socialdemocracia. Problemas del socialismo. El revisionismo en la socialdemocracia. México: Siglo Veintiuno, 1982, p.68. 
Tabela 4: Número de pessoas empregadas em empresas de acordo com os censos industriais alemães.

\begin{tabular}{|l|c|c|c|c|}
\hline & \multicolumn{2}{|c|}{ Quantidades } & \multicolumn{2}{c|}{ Pessoas empregadas } \\
\hline Estabelecimentos & 1895 & 1907 & 1895 & 1907 \\
\hline $\begin{array}{l}\text { Muito pequenos } \\
\text { (só 1 pessoa) }\end{array}$ & 1.029 .954 & 955.707 & 1.029 .954 & 955.707 \\
\hline $\begin{array}{l}\text { Pequenas } \\
\text { empresas } \\
\text { (2 a 5 operários) }\end{array}$ & 593.884 & 767.200 & 1.638 .205 & 2.038 .236 \\
\hline $\begin{array}{l}\text { Empresas } \\
\text { medianas } \\
\text { (6-50 operários) }\end{array}$ & 108.800 & 154.330 & 1.390 .745 & 2.109 .164 \\
\hline $\begin{array}{l}\text { Grandes } \\
\text { empresas } \\
\text { (51-500 } \\
\text { operários) }\end{array}$ & 10.127 & 17.287 & 1.287 .085 & 2.095 .065 \\
\hline $\begin{array}{l}\text { Muito grandes } \\
\text { (501-1000 } \\
\text { pessoas }\end{array}$ & 380 & 602 & & \\
\hline $\begin{array}{l}\text { Gigantescos } \\
\text { (acima } \\
1001 \text { pessoas) }\end{array}$ & 191 & 371 & 338.585 & 710.253 \\
\hline Total & 1.743 .336 & 1.895 .497 & 5.876 .083 & 8.332 .912 \\
\hline
\end{tabular}

Fonte: BERNSTEIN. Socialismo evolucionário. Rio de Janeiro: Zahar, p.164.

Tabela 5: Propriedades agrícolas na Alemanha em 1895.

\begin{tabular}{|l|c|c|c|}
\hline $\begin{array}{l}\text { Espécie de } \\
\text { propriedade }\end{array}$ & Número de propriedades & $\begin{array}{c}\text { Número de hectares para fins } \\
\text { agrícolas }\end{array}$ & $\begin{array}{c}\text { Área total em } \\
\text { hectares }\end{array}$ \\
\hline $\begin{array}{l}\text { Muito pequena } \\
\text { (até2 hectares) }\end{array}$ & 3.236 .367 & 1.808 .444 & 2.415 .414 \\
\hline $\begin{array}{l}\text { Pequenos } \\
\text { camponeses } \\
(2-5 \text { hectares) }\end{array}$ & 1.016 .318 & 3.285 .984 & 4.142 .071 \\
\hline $\begin{array}{l}\text { Camponeses } \\
\text { médios (5-20 } \\
\text { hectares) }\end{array}$ & 998.804 & 9.721 .875 & 12.537 .660 \\
\hline $\begin{array}{l}\text { Grandes } \\
\text { camponeses (20- } \\
\text { 100 hectares) }\end{array}$ & 281.767 & 9.869 .837 & 13.157 .201 \\
\hline $\begin{array}{l}\text { Grandes } \\
\text { proprietários } \\
\text { (acima de 100 } \\
\text { hectares) }\end{array}$ & 25.061 & & 11.031 .896 \\
\hline
\end{tabular}

Fonte: BERNSTEIN. Socialismo evolucionário. Rio de Janeiro: Zahar, p.70. 
Tabela 6: Número de pessoas que pagaram imposto de renda na Saxônia em 1894 e 1897.

\begin{tabular}{|l|c|c|c|c|}
\hline Renda (£) & 1897 & 1894 & $\begin{array}{c}\text { Aumento } \\
\text { absoluto }\end{array}$ & $\begin{array}{c}\text { Aumento } \\
\text { percentual }\end{array}$ \\
\hline Até 40 & 828.686 & 972.257 & 143.571 & 17.3 \\
\hline 40 a 80 & 165.362 & 357.974 & 192.612 & 116.4 \\
\hline $\begin{array}{l}\text { Rendas dos } \\
\text { proletários }\end{array}$ & 994.048 & 1.330 .231 & 336.183 & 33.8 \\
\hline
\end{tabular}

\begin{tabular}{|l|c|c|c|c|}
\hline \multicolumn{1}{|c|}{ Renda (£) } & 1897 & 1894 & $\begin{array}{c}\text { Aumento } \\
\text { absoluto }\end{array}$ & $\begin{array}{c}\text { Aumento } \\
\text { percentual }\end{array}$ \\
\hline 80 a 165 & 61.810 & 106.136 & 44.326 & 71.6 \\
\hline 165 a 480 & 24.072 & 41.890 & 17.818 & 74 \\
\hline 480 a 2.700 & 4.683 & 10.518 & 5.835 & 154.4 \\
\hline $\begin{array}{l}\text { Acima de } \\
2.700\end{array}$ & 238 & 886 & 648 & 272 \\
\hline Total & 1.084 .851 & 1.489 .661 & Média: & $37 . .3$ \\
\hline
\end{tabular}

Fonte: BERNSTEIN. Socialismo evolucionário. Rio de Janeiro: Zahar, p.58. 